UNIVERSIDADE DE SÃO PAULO
INSTITUTO DE RELAÇÕES INTERNACIONAIS
PROGRAMA DE PÓS-GRADUAÇÃO EM RELAÇÕES INTERNACIONAIS

LUCAS DA SILVA TASQUETTO

EDUCAÇÃO E COMÉRCIO INTERNACIONAL: IMPACTOS DA

LIBERALIZAÇÃO COMERCIAL DOS SERVIÇOS SOBRE A REGULAÇÃO DA EDUCAÇÃO SUPERIOR NO BRASIL 


\title{
EDUCAÇÃO E COMÉRCIO INTERNACIONAL: IMPACTOS DA LIBERALIZAÇÃO COMERCIAL DOS SERVIÇOS SOBRE A REGULAÇÃO DA EDUCAÇÃO SUPERIOR NO BRASIL
}

\author{
LUCAS DA SILVA TASQUETTO
}

Tese apresentada ao Programa de Pós-Graduação em Relações Internacionais do Instituto de Relações Internacionais da Universidade de São Paulo, para a obtenção do título de Doutor em Ciências - Programa de Pós-Graduação em Relações em Internacionais

Orientadora: Prof. Dra. Deisy de Freitas Lima Ventura

Versão corrigida

Durante o desenvolvimento deste trabalho, o autor recebeu auxílio financeiro da FAPESP -

Fundação de Amparo à Pesquisa do Estado de São Paulo

São Paulo

2014 


\section{AGRADECIMENTOS}

Agradeço o apoio da FAPESP - Fundação de Amparo à Pesquisa do Estado de São Paulo.

Ao Instituto de Relações Internacionais da Universidade de São Paulo, em especial aos professores João Paulo Cândia e Yi Shin Tang, pelo aprendizado durante as experiências como monitor junto à graduação.

Ao King's Brazil Institute da King's College London, em especial ao professor Alvaro Comin pela acolhida durante o período do doutorado sanduíche.

À orientadora Deisy Ventura, pela confiança e apoio constantes.

Aos amigos do IRI, companheiros de jornada durante os anos do doutorado, e aos demais amigos que ajudaram de alguma forma na realização da pesquisa e tornaram especial o período em São Paulo, Londres e nos demais lugares por onde passei.

Aos meus pais e a minha irmã, pelo carinho, compreensão e atenção. 


\section{RESUMO}

Esta tese aborda o desenvolvimento da regulação internacional sobre o comércio de serviços educacionais, em especial nos acordos preferenciais de comércio de Austrália, Chile, China, Cingapura, Estados Unidos, Índia e União Europeia. O seu objetivo foi avaliar o atual nível de liberalização comercial da educação superior no plano global, de modo que sua compatibilidade com o direito à educação pudesse ser criticamente analisada, assim como os seus possíveis impactos sobre a regulação da educação superior no Brasil. Para tanto, a pesquisa começa pela realização de entrevistas com atores que acompanham o processo de comercialização da educação superior no Brasil. Os passos seguintes envolvem a compreensão do funcionamento das disciplinas internacionais sobre o comércio de serviços, da formulação das posições no processo negociador e, finalmente, dos compromissos em serviços de educação superior em acordos preferenciais de comércio. Uma primeira hipótese é de que, mesmo sem acordos de comércio, o mercado brasileiro já se encontra significativamente liberalizado no que diz respeito aos investimentos estrangeiros em educação superior, sem qualquer restrição ao ingresso de capital internacional. Ainda assim, a regulação internacional do comércio de serviços aprofundaria esse processo a partir da ideia de consolidação do marco regulatório liberal doméstico e de mecanismos que conduzem à aceleração do processo de liberalização comercial.

Palavras-chave: educação superior; serviços educacionais; GATS; acordos preferenciais de comércio; liberalização comercial. 


\begin{abstract}
This thesis analyses the development of international regulation on trade in educational services, especially in preferential trade agreements signed by Australia, Chile, China, Singapore, United States, India and the European Union. The goal was to determine a parameter of the current global level of trade liberalization on higher education, so that the compatibility between trade agreements and the right to education could be critically examined, as well as their possible impacts on the regulation of higher education in Brazil. Therefore, the research began by conducting interviews with professionals that accompany the commercialization process in the Brazilian higher education sector. The following steps involved understanding the operation of international disciplines on trade in services, the formulation of positions in the negotiating process, and finally, the commitments on higher education services in preferential trade agreements. A first hypothesis is that, even without trade agreements, the Brazilian market is already significantly liberalized regarding foreign investment on higher education, without any restriction on the inflow of international capital. Even so, international regulation on trade in services would deepen this process from an idea of consolidation of a liberal domestic regulatory framework and mechanisms leading to accelerate trade liberalization process.
\end{abstract}

Keywords: higher education; educational services; GATS; preferential trade agreements; trade liberalization. 


\section{LISTA DE SIGLAS}

ABMES - Associação Brasileira de Mantenedoras de Educação Superior

ACC - Acordo em controle de concentrações

ANDIFES - Associação Nacional dos Dirigentes das Instituições Federais de Ensino Superior

APCs - Acordos Preferenciais de Comércio

CADE - Conselho Administrativo de Defesa Econômica

CAPES - Coordenação de Aperfeiçoamento de Pessoal de Nível Superior

CCJC - Comissão de Constituição e Justiça e de Cidadania

CCS - Conselho de Comércio para Serviços da Organização Mundial do Comércio

$\mathbf{C E}$ - Comissão de Educação

CEC - Comissão de Educação e de Cultura da Câmara dos Deputados

CFT - Comissão de Finanças e Tributação

CPC - Conceito Preliminar de Curso

CONAES - Comissão Nacional de Avaliação da Educação Superior

CONSED - Conselho Nacional de Secretários de Educação

CTASP - Comissão de Trabalho, de Administração e Serviço Público

DUDH - Declaração Universal dos Direitos Humanos

EAD - Ensino à distância

EFTA - Associação Europeia de Livre Comércio

ENADE - Exame Nacional de Desempenho de Estudantes

ENEM - Exame Nacional do Ensino Médio

FAUBAI - Fórum de Assessorias das Universidades Brasileiras para Assuntos Internacionais

FEPESP - Federação dos Professores do Estado de São Paulo

FMI - Fundo Monetário Internacional 
GATS - Acordo Geral sobre o Comércio de Serviços

GATT - Acordo Geral sobre Tarifas e Comércio

IGC - Índice Geral de Cursos Avaliados da Instituição

INEP - Instituto Nacional de Estudos e Pesquisas Educacionais Anísio Teixeira

INSAES - Instituto Nacional de Supervisão e Avaliação da Educação Superior

IPO - Oferta Pública Inicial

LDB - Lei de Diretrizes e Bases da Educação Brasileira

MDIC - Ministério do Desenvolvimento, Indústria e Comércio Exterior

MEC - Ministério da Educação

MRE - Ministério das Relações Exteriores

NAFTA - Tratado Norte-Americano de Livre Comércio

OCDE - Organização para a Cooperação e Desenvolvimento Econômico

OMC - Organização Mundial de Comércio

ONU - Organização das Nações Unidas

PC do B - Partido Comunista do Brasil

PDT - Partido Democrático Trabalhista

PNAD - Pesquisa Nacional por Amostra de Domicílios

PR - Partido da República

PROUNI - Programa Universidade para Todos

PSOL - Partido Socialismo e Liberdade

PT - Partido dos Trabalhadores

SERES - Secretaria de Regulação e Supervisão da Educação Superior

SESU - Secretaria de Educação Superior

SINAES - Sistema Nacional de Avaliação da Educação Superior

UNE - União Nacional de Estudantes

UNESCO - Organização das Nações Unidas para a Educação, a Ciência e a Cultura 
UNIASSELVI - Centro Universitário Leonardo da Vinci 


\section{ÍNDICE DE TABELAS}

Tabela 01 - Comparação entre o modelo GATS de lista positiva e o modelo Nafta de lista negativa para a consolidação de compromissos de liberalização nos acordos preferenciais de comércio (p. 125).

Tabela 02 - Barreiras Comerciais (p. 150).

Tabela 03 - Total de acordos preferenciais de comércio analisados (p. 152).

Tabela 04 - Acordos preferenciais de comércio entre os atores analisados (p. 153).

Tabela 05 - Acordos Preferenciais de Comércio dos Estados Unidos (p. 157)

Tabela 06 - Regras sobre Comércio de Serviços (Estados Unidos) (p. 158).

Tabela 07 - Acordos Preferenciais de Comércio da Austrália (p. 163).

Tabela 08 - Regras sobre Comércio de Serviços (Austrália) (p. 164).

Tabela 09 - Acordos Preferenciais de Comércio do Chile (p. 169).

Tabela 10 - Regras sobre Comércio de Serviços (Chile) (p. 171).

Tabela 11 - Acordos Preferenciais de Comércio de Cingapura (p. 177).

Tabela 12 - Regras sobre Comércio de Serviços (Cingapura) (p. 179).

Tabela 13 - Acordos Preferenciais de Comércio da Índia (p. 187).

Tabela 14 - Regras sobre Comércio de Serviços (Índia) (p. 188).

Tabela 15 - Acordos Preferenciais de Comércio da China (p. 194).

Tabela 16 - Regras sobre Comércio de Serviços (China) (p. 196).

Tabela 17 - Acordos Preferenciais de Comércio da União Europeia (p. 199).

Tabela 18 - Regras sobre Comércio de Serviços (União Europeia) (p. 200).

Tabela 19 - Entrevistas (p. 231). 
Tabela 20 - Evolução do número de matrículas de graduação no Brasil (p. 233).

Tabela 21 - Instituições de graduação de ensino superior (p. 234).

Tabela 22 - Cursos de graduação de ensino superior (p. 234).

Tabela 23 - Número de matrículas de graduação presencial por turno segundo a categoria administrativa (p. 235).

Tabela 24 - Transações no setor educacional no Brasil (Pesquisa de Fusões e Aquisições KPMG) (p. 236). 


\section{SUMÁRIO}

\section{INTRODUÇÃO.}

1. A EDUCAÇÃO SUPERIOR PRIVADA COM FINS LUCRATIVOS: UMA VISÃO DOS ATORES SOBRE A EXPANSÃO DO SETOR .............................13

1.1 Justificativa para a escolha de uma abordagem metodológica qualitativa.........13

1.2 Delimitação das entrevistas: atores e questionamentos..................................16

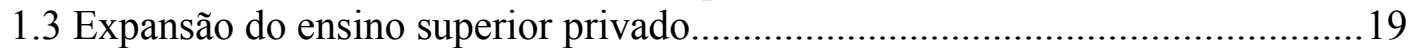

1.4 A gestão acadêmica em relação à gestão empresarial em um contexto de comercialização da educação superior................................................................29

1.4.1 A relação entre o professor e o aluno como cliente/consumidor.................34

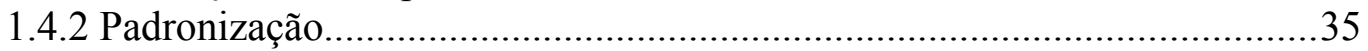

1.4.3 Investimentos em pesquisa e pós-graduação stricto sensu.......................40

$1.5 \mathrm{O}$ outro lado da profissionalização: precarização da docência..........................43

1.6 Os grandes grupos educacionais e o ensino de massa....................................46

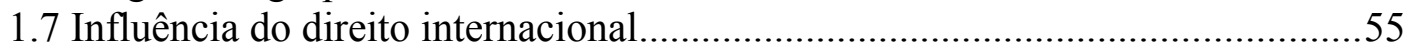

1.8 Controle sobre a participação do capital estrangeiro......................................57

1.9 Marco regulatório sobre a educação superior: regulação, avaliação e supervisão

1.10 A criação do Instituto Nacional de Supervisão e Avaliação da Educação Superior (INSAES) e a análise diferenciada no CADE dos casos de fusões e aquisições no setor educacional.

\section{EDUCAÇÃO SUPERIOR E REGULAÇÃO DO COMÉRCIO}

2.1 Natureza da educação superior: de bem público e direito humano a sua inserção

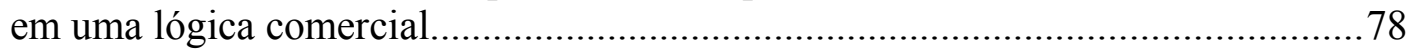

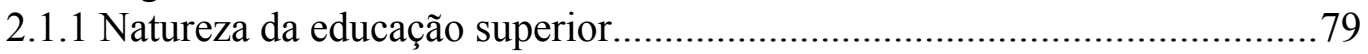

2.1.2 Direito à educação no direito internacional dos direitos humanos............84

2.1.3 Direitos humanos e comércio internacional...............................................8 88

2.2 Regulamentação multilateral do comércio de serviços sob a perspectiva dos serviços educacionais.

2.2.1 Comércio de serviços: Acordo Geral sobre Comércio de Serviços (GATS)

2.2.2. Liberalização do comércio de serviços por meio da lista positiva............103

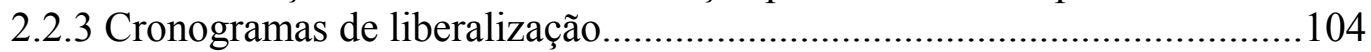

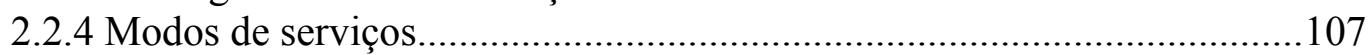

2.2.5 Exclusão dos serviços prestados no exercício da autoridade governamental

2.3 Do multilateralismo para os acordos preferenciais de comércio......................112

2.3.1 Panorama sobre as tendências de regulação nos acordos preferenciais de comércio.

2.3.2 Liberalização do comércio de serviços por meio da lista negativa............122

$2.4 \mathrm{O}$ processo negociador em matéria de serviços educacionais...........................123

2.4.1 A escolha entre o método da lista positiva e o método da lista negativa: impactos regulatórios................................................................................. 124

2.4.2 Definição das posições negociadoras em comércio de serviços educacionais: o regulador e o negociador comercial...................................... 129 
2.4.3 Complexidades sob a perspectiva do comércio de serviços - questões regulatórias.

2.4.4 Complexidades da relação entre o regulador e o negociador comercial -

educação superior. 132

3. OS ACORDOS PREFERENCIAIS DE COMÉRCIO E A LIBERALIZAÇÃO DO COMÉRCIO DE SERVIÇOS DE EDUCAÇÃO SUPERIOR.......................143

3.1 Pressupostos metodológicos para a análise..................................................144

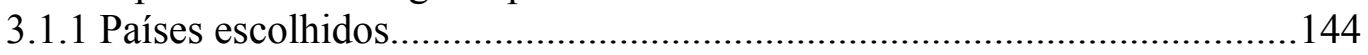

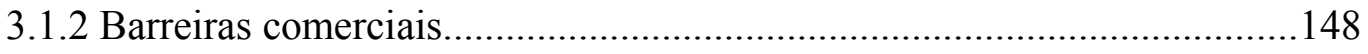

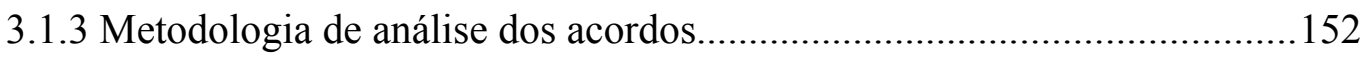

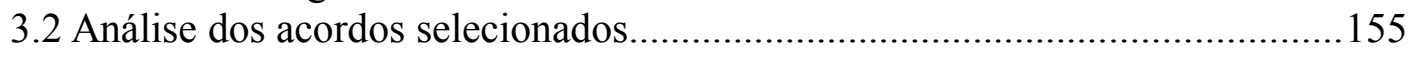

3.2.1 Acordos preferenciais de comércio dos Estados Unidos.........................156

3.2.2 Acordos preferenciais de comércio da Austrália........................................162

3.2.3 Acordos preferenciais de comércio do Chile.............................................168

3.2.4 Acordos preferenciais de comércio de Cingapura..................................176

3.2.5 Acordos preferenciais de comércio da Índia.............................................186

3.2.6 Acordos preferenciais de comércio da China...........................................194

3.2.7 Acordos preferenciais de comércio da União Europeia............................198

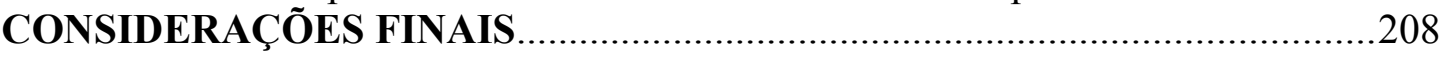

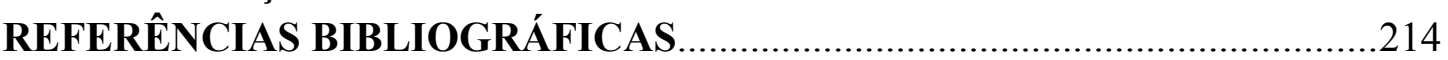

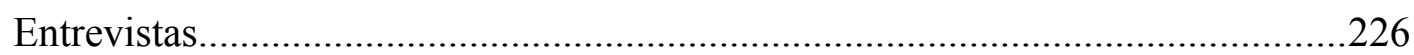

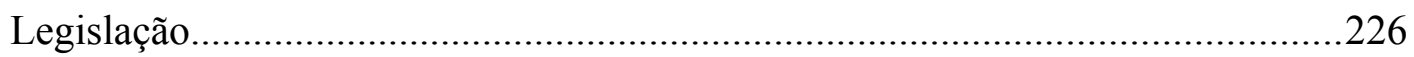

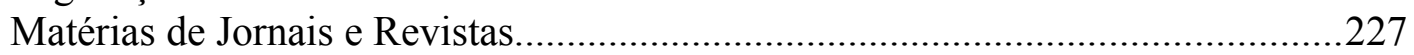

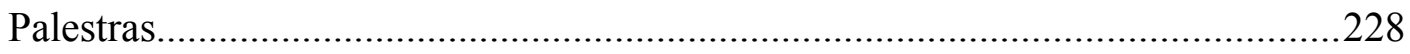

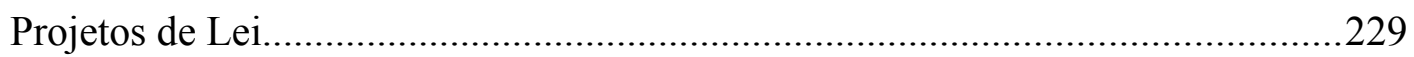

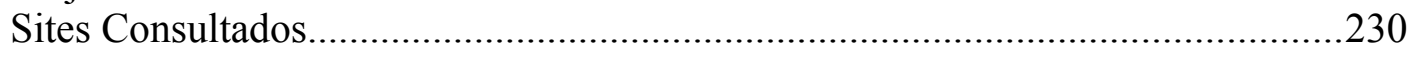

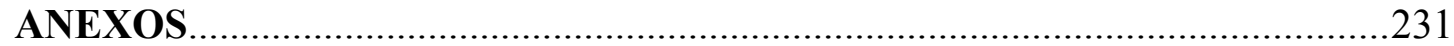




\section{INTRODUÇÃO}

Como um processo multifacetado, a globalização econômica traz consequências sociais, políticas e culturais no campo da educação superior. Nos últimos anos, os Estados e a comunidade acadêmica têm encontrado dificuldades para manter sua capacidade de influência nos processos de tomada de decisão, cada vez menos circunscritos aos limites das fronteiras nacionais. Além de questões de acesso, equidade, financiamento e qualidade da educação, estão em jogo elementos de soberania nacional, diversidade cultural, pobreza e desenvolvimento sustentável. Grassa o temor de que o comércio de serviços educacionais submeta a educação ao domínio do mercado, o que comprometeria seriamente a capacidade do Estado de regular a educação superior de forma condizente com sua condição de política pública. ${ }^{1}$

A intensificação do fluxo entre as fronteiras transforma continuamente as identidades nacionais, o que levou alguns autores a imaginar a educação superior como um único arranjo global ${ }^{2}$. Não se trataria de um "sistema global" unitário, mas de uma complexa combinação de fluxos e redes globais de palavras e ideias, conhecimento, finanças e relações interinstitucionais; com sistemas nacionais de educação superior formados pela história, pelo direito, pelas políticas e financiamento, e instituições individuais operando local, nacional e globalmente.

Nesse cenário, as instituições privadas lucrativas, com características que as assemelham a uma "indústria de serviços educacionais", jovem e de grande dinamismo, ainda pouco estável. Como decorrência de uma lógica comercial, boa parte do tamanho e da capacidade das companhias é determinada por fusões e aquisições, o que significa que o número de participantes no mercado diminui, mas eles crescem em tamanho. ${ }^{4} \mathrm{O}$ movimento das corporações educacionais e a prática de fusões e aquisições não só desvendam o potencial estratégico para

\footnotetext{
${ }^{1}$ ORGANIZAÇÃO DAS NAÇÕES UNIDAS PARA A EDUCAÇÃO, A CIÊNCIA E A CULTURA. Higher Education in a Globalized Society. UNESCO Education Position Paper, 2004, p. 6.

${ }^{2}$ MARGINSON, Simon. Dynamics of national and global competition in higher education. Higher Education, v. 52, 2006, p. 1-2.

${ }^{3}$ BALL, Stephen J. Education plc: Understanding private sector participation in public sector education. Abingdon: Routledge, 2007, p. 57.

${ }^{4}$ BALL, Stephen J. Education plc: Understanding private sector participation in public sector education, p. 57-59.
} 
investimento e geração de lucros da educação superior, mas também a escala global da mercantilização. Assim, estas corporações estão envolvidas na produção e na promoção da globalização no campo da educação superior, a fim de gerar uma cadeia global com fins lucrativos. ${ }^{5}$

Nos países em vias de desenvolvimento, a liberalização econômica, a demanda crescente e a diminuição dos recursos públicos dedicados à educação superior pressionam o setor público, dando lugar a uma rápida expansão dos estabelecimentos privados. ${ }^{6}$ No Brasil, particularmente a partir dos anos 1990, cresce o número de instituições com fins lucrativos, representando hoje mais de três quartos do setor educacional privado. O ingresso destas instituições na Bolsa de Valores, em 2007, envolve três grupos: Anhanguera Educacional S.A., Kroton Educacional S.A. e Estácio Participações S.A., que passaram a adquirir instituições menores. Em 2013, mais dois grupos nacionais realizaram uma oferta pública de ações: o Ser Educacional e o Anima Educação. Ao mesmo tempo, grupos educacionais estrangeiros, em especial Laureate International Universities, Whitney University System e DeVry University, consolidaram e estenderam sua presença no país por meio da aquisição de novas instituições de ensino superior.

\section{Regulação do comércio internacional de serviços}

Os interesses das corporações convergem na busca de regras vinculantes, globais e irreversíveis em matéria de comércio de serviços. Ao estenderem seu alcance mundial, cada vez mais procuram reduzir o custo do cumprimento da regulação imposta por diferentes países. Assim, a adoção de regras em escala mundial para reduzir ou eliminar barreiras nacionais à sua atividade comercial passa a ser uma prioridade fundamental de muitas dessas corporações que operam nos setores de serviços. ${ }^{7}$ Em um primeiro momento, o conjunto de interesses no acesso a mercados e na garantia de tratamento nacional aos prestadores estrangeiros de serviços conduziu à elaboração do Acordo Geral sobre Comércio de

\footnotetext{
${ }^{5}$ GOMES, Alfredo M.; ROBERTSON, Susan L.; DALE, Roger. The social condition of higher education: globalisation and (beyond) regionalisation in Latin America, Globalisation, Societies and Education, v.10, n.2, 2012, p. 233.

${ }^{6}$ GROSBON, Sophie. Le droit à l'enseignement supérieur et la liberalisation international du commerce des services. Bruxelles: Bruylant, 2010, p. -5-6.

${ }^{7}$ SINCLAIR, Scott. GATS: How the World Trade Organization's new 'services' negotiations threaten democracy, Canadian Centre for Policy Alternatives, September 2000, p. 3.
} 
Serviços (GATS), em vigor desde janeiro de 1995, como resultado das negociações no âmbito da Rodada Uruguai, que criou a Organização Mundial do Comércio (OMC). O Acordo consolidou um ambiente favorável ao livre comércio e à expansão do setor privado. O poder regulatório e as prerrogativas da OMC fazem dele um elemento central na governança educacional global. ${ }^{8}$

No entanto, sendo os serviços educacionais um setor relativamente pouco consolidado nas listas do GATS, sua liberalização é ampliada no âmbito da proliferação dos acordos preferenciais de comércio - regionais ou bilaterais -, com um significativo aumento no número de compromissos oferecidos pelos países. A transferência das negociações do ambiente multilateral para os acordos preferenciais torna fundamental o estudo das tendências de regulação trazidas por esses novos instrumentos, assim como o mapeamento dos compromissos já assumidos, a fim de informar os países em desenvolvimento sobre as escolhas políticas com as quais se confrontarão ao negociar regimes regionais e bilaterais para o comércio de serviços e investimentos.

Os cronogramas do GATS e, posteriormente, os compromissos e reservas apresentados nos acordos preferenciais de comércio são uma das poucas fontes de dados disponíveis para identificar e avaliar a extensão das restrições comerciais concernentes aos serviços educacionais. ${ }^{9}$ A racionalidade econômica subjacente às reformas regulatórias é a de que a remoção das barreiras ao comércio de serviços resultaria em menores preços, maior qualidade e grande concorrência entre os prestadores. ${ }^{10}$ Por conseguinte, as medidas que se encontram à disposição do regulador doméstico para a regulamentação do ensino superior no país, quando enfocadas sob a lógica de acordos comerciais, podem ser consideradas barreiras ao livre comércio que devem ser eliminadas. As preocupações crescentes da comunidade acadêmica em todo o mundo derivam justamente do fato de que a OMC, uma organização voltada primordialmente a promover o comércio para fins de eficiência

\footnotetext{
${ }^{8}$ VERGER, Antoni. The constitution of a new global regime: Higher education in the GATS/WTO framework. In: EPSTEIN, Debbie; BODEN, Rebecca; DEEM, Rosemary; RIZVI, Fazal; WRIGHT, Susan (edit.). World Yearbook of Education 2008 - Geographies of Knowledge, Geometries of Power: Framing the Future of Higher Education. New York: Routledge, 2007, p. 115.

${ }^{9}$ KEMP, Steven. Trade in education services and the impacts of barriers to trade. In: FINDLAY, Christopher; WARREN, Tony (eds.). Impediments to Trade in Services: Measurement and Policy Implications. New York: Routledge, 2000, p. 260.

${ }^{10}$ RAYCHAUDHURI, Ajitava; DE, Prabir. Barriers to Trade in Higher Education Services - Empirical Evidence from Asia-Pacific Countries, p. 76.
} 
econômica, sem competência específica na educação, possa afetar negativamente o desenvolvimento sustentável no campo da educação, ${ }^{11}$ e que esta dinâmica venha a ser aprofundada nos acordos preferenciais de comércio.

\section{Liberalização doméstica mesmo sem compromissos em acordos comerciais}

De outro lado, a transnacionalização da educação, em especial da educação superior, intensifica-se de maneira independente em relação ao comércio de serviços no âmbito de acordos comerciais. Não é de se esperar que novas negociações multilaterais, regionais ou bilaterais possam frear essa tendência ou acelerar drasticamente o processo, na medida em que tendem a refletir e consolidar o quadro regulatório doméstico dos Estados, cuja agenda ainda é em sua maior parte nacional. Ao mesmo tempo, os mercados podem estar abertos apesar da ausência de compromissos de liberalização, e é possível também que um acordo não reflita o nível existente de abertura de mercado. Por conseguinte, não é correto afirmar que a simples ausência de compromissos indica um mercado fechado. Com a educação privada e a educação pública coexistindo na maioria dos países, é de se esperar que muitos mercados já sejam liberais, o que enseja menos a questão de saber se o setor privado deve ter um papel na provisão da educação, e mais de saber o quanto os prestadores estrangeiros devem ser encorajados a ingressar no território nacional. ${ }^{12}$

No Brasil, particularmente, ainda que o país não tenha oferecido qualquer compromisso de abertura comercial para prestadores estrangeiros de serviços educacionais junto à OMC ou outro acordo comercial internacional, o setor privado da educação superior já se encontra significativamente liberalizado, sem dispositivos legais que limitem ou proíbam a presença no país do capital estrangeiro. Ao ingressarem, os investidores educacionais estrangeiros sujeitam-se ao mesmo quadro regulatório educacional ao qual estão submetidas as instituições nacionais de ensino superior. Mais do que isso, o conjunto do setor privado educacional com fins lucrativos cresce continuamente no país, com o ingresso dos principais grupos educacionais internacionais por meio da aquisição de instituições domésticas, além da

\footnotetext{
${ }^{11}$ ORGANIZAÇÃO DAS NAÇÕES UNIDAS PARA A EDUCAÇÃO, A CIÊNCIA E A CULTURA. Higher Education in a Globalized Society, p. 9.

${ }^{12}$ LIM, Aik Hoe; SANER, Raymond. Rethinking Trade in Education Services: A Wake-Up Call for Trade Negotiators, Journal of World Trade, v. 45, n. 5, 2011, p. 1029.
} 
participação ou do controle de grupos educacionais brasileiros com capital aberto na bolsa de valores por fundos de investimentos estrangeiros.

\section{Questões terminológicas}

É importante diferenciar a "internacionalização" da educação superior, ligada aos conceitos tradicionais de cooperação interinstitucional, mobilidade acadêmica e do conhecimento, e "transnacionalização" da educação superior, termo adotado para se referir ao processo de comercialização da educação superior em escala global. ${ }^{13}$ A principal diferença entre internacionalização e transnacionalização não é a escala de operações, pois ambas remetem à dimensão global, mas sim ao modo de estruturação de suas relações naquela esfera. Enquanto a internacionalização da educação não é algo novo e estrutura as relações da comunidade acadêmica com base em fronteiras nacionais, a transnacionalização constitui um circuitos de trocas e comércio de serviços que transcendem as fronteiras. ${ }^{14}$ Nesse processo, interessa especificamente à pesquisa em questão a crescente influência do setor privado com fins lucrativos da educação superior, em especial a presença comercial de grupos educacionais estrangeiros em outros países, com a aquisição de instituições domésticas de ensino superior - no Brasil, por exemplo, isto ocorre por meio da transferência de mantença - e a participação acionária em grupos educacionais domésticos com capital aberto na bolsa de valores.

No momento em que a educação superior passa a obedecer a lógica do direito do comércio internacional, uma nova gramática desafia quem pretenda considerar conjuntamente a perspectiva do regulador educacional doméstico e a do negociador comercial. A começar pelo tratamento da educação como um serviço comercializável, a prática corrente dos negócios e as regras comerciais geram um novo arsenal terminológico. Além de inserir formalmente a educação em uma dinâmica por excelência comercial, o GATS estabelece os setores e subsetores, e os

\footnotetext{
13 Semelhante distinção de significados também é feita em relação à "globalização" e à "internacionalização". Ambos os conceitos seriam erroneamente utilizados como sinônimos. Em um documento da UNESCO, por exemplo, a "globalização" é apresentada como um fenômeno que tem impacto sobre a educação superior, e a "internacionalização" como uma das formas de responder às oportunidades e desafios da globalização (ORGANIZAÇÃO DAS NAÇÕES UNIDAS PARA A EDUCAÇÃO, A CIÊNCIA E A CULTURA. Higher Education in a Globalized Society, p. 6).

${ }^{14}$ VERGER, Antoni. The constitution of a new global regime: Higher education in the GATS/WTO framework, p. 111.
} 
modos de prestação por meio dos quais são liberalizados os serviços educacionais. Consequentemente, também determina os conceitos e as categorias que estruturam a regulação na matéria, replicados posteriormente nos capítulos de comércio de serviços e investimentos dos principais acordos preferenciais de comércio assinados regional ou bilateralmente.

Nessa dinâmica da prestação privada da educação superior e dos fluxos de comércio no setor, conceitos e expressões até então estranhos à literatura sobre educação, e mesmo ao cotidiano do regulador educacional doméstico, devem ser esclarecidos por este trabalho. Essa tarefa decorre do objetivo de considerar as percepções de atores do setor privado com fins lucrativos da educação superior e, sobretudo, de analisar as regras, compromissos de liberalização e reservas em matéria de serviços educacionais aos quais se submetem os países por conta de sua participação em acordos de comércio. Logo, expressões como "mercado", "barreiras comerciais" e "preferências comerciais", por exemplo, ainda que pareçam impróprias quando utilizadas em referência às relações entre prestadores de serviço e seus usuários na área social (devido ao seu caráter público, que veda a sua redução às categorias aplicáveis aos serviços econômicos ${ }^{15}$ ), formam parte do próprio texto dos acordos comerciais e, por consequência, do direito do comércio internacional.

Em segundo lugar, mais como decorrência de um amplo processo de comercialização da educação superior - tanto no âmbito nacional quanto no âmbito global - do que propriamente do desenvolvimento regulatório no campo do comércio internacional de serviços, expressões eminentemente mercadológicas encontram-se naturalizadas nos meios de comunicação, bem como nos documentos para o mercado, relatórios e pareceres de organizações como OMC, Banco Mundial e Organização para a Cooperação e Desenvolvimento Econômico (OCDE). A disseminação de um vocabulário originário do setor privado - "lucros", "empreendedorismo", “companhias", “inovação", "melhores práticas", "receitas", etc. - traz consigo expressões que representam novas formas de pensamento sobre a educação, constituindo uma poderosa meta-narrativa. ${ }^{16} \mathrm{O}$ emprego deste léxico na presente tese

\footnotetext{
${ }^{15}$ BUCCI, Maria Paula Dallari. O Art. 209 da Constituição 20 anos Depois. Estratégias do Poder Executivo para a Efetivação da Diretriz da Qualidade da Educação Superior. In: SOUZA NETO, Cláudio Pereira; SARMENTO, Daniel; BINENBOJM, Gustavo (coord.). Vinte Anos da Constituição Federal de 1998. Rio de Janeiro: Editora Lumen Juris, 2009, p. 783.

${ }^{16}$ BALL, Stephen J. Education plc: Understanding private sector participation in public sector education, p. 31.
} 
busca respeitar a terminologia adotada nos instrumentos jurídicos internacionais, assim como a escolhida pelo autores das fontes consultadas, sem que isto signifique necessariamente a adesão do candidato ao seu uso corrente.

\section{O papel do direito internacional}

A partir dos anos 1990, a disseminação do discurso liberal contribuiu para a naturalização de assimetrias entre os Estados, na medida em que toma a economia global como dada, sem nunca problematizá-la, reduzindo sobremaneira o espaço da política, além de ignorar o papel do direito na criação de regimes assimétricos. ${ }^{17}$ Assim, os esforços teóricos de acadêmicos de cunho liberal foram direcionados a uma abordagem gerencial do direito, com a expansão de redes de técnicos, prontos a implementarem políticas de "melhores práticas" que invocam a associação com necessidades objetivas e suposta eficiência, em lugar de tratar de posições políticas e de estratégias de distribuição. ${ }^{18}$ Nesse contexto, o espaço da política é virtualmente suplantado pela tecnocracia, e o soft law de instituições como o Fundo Monetário Internacional (FMI) e Banco Mundial, também em matéria educacional, é instrumentalizado para fazer avançar uma ordem global assimétrica, que abre mercados justamente onde os atores poderosos encontram vantagens comparativas. ${ }^{19}$ Esteio sobre o qual se erige o processo de liberalização comercial desde o final da década de 1980, a tecnocracia internacional determina a natureza das políticas e regras destinadas à comercialização da educação superior nos níveis nacional e internacional, com crescente permeabilidade entre ambos.

A separação da atividade econômica da contestação política é um projeto que encontra as suas raízes no esforço de buscar economia e política em diferentes escalas. Enquanto a primeira se tornou global, a segunda permanece ligada às estruturas governamentais locais. O resultado disso é a ruptura entre a política local e nacional de um lado, e a economia global e a sociedade do outro. ${ }^{20}$ Essa prática, facilmente identificável, faz-se presente também nos discursos dos principais

\footnotetext{
${ }^{17}$ SOUZA, Igor Abdalla Medina de. O liberalismo interdisciplinar DI/RI no pós-Guerra Fria: Uma análise crítica. Revista Ética e Filosofia Política, n. 13, v. 2, Jun. 2011, p. 25.

${ }^{18}$ SOUZA, Igor Abdalla Medina de. O liberalismo interdisciplinar DI/RI no pós-Guerra Fria: Uma análise crítica, p. 26-32.

${ }^{19}$ SOUZA, Igor Abdalla Medina de. O liberalismo interdisciplinar DI/RI no pós-Guerra Fria: Uma análise crítica, p. 26.

${ }^{20}$ KENNEDY, David. Law and the Political Economy of the World, Leiden Journal of International Law, v. 26, 2013, p. 12.
} 
representantes do setor educacional privado com fins lucrativos, ${ }^{21}$ que rechaçam a presença de funcionários públicos nas discussões em torno da liberalização comercial da educação superior, no sentido de que o debate em torno do setor privado só diria respeito aos próprios empresários, e não mais ao Estado. Aqui se procura confundir a posição do empresariado com a própria posição do Estado, como se a este não mais coubesse espaço na regulação do campo econômico.

O convívio entre a política territorializada e a economia desterritorializada depende de um arcabouço técnico e jurídico. A atividade econômica só acontece em escala global mediante arranjos institucionais que o garantam. ${ }^{22}$ Naturalmente, esse parece ser também o desenho da regulação da educação superior. A engrenagem atua paralelamente nas duas esferas. Enquanto a política doméstica garante a implementação de um marco liberal para a comercialização da educação superior no país, a regulação internacional procura consolidar os compromissos domésticos já assumidos por diferentes países, com garantias de acesso a mercados e tratamento nacional também a investidores estrangeiros. Resta ao Estado fiscalizar adequadamente as instituições, desprovido, porém, de condições de rediscutir o sistema, enquanto o setor privado busca cada vez mais afastar a política da economia, ainda que use os canais formais para garantir as suas demandas especificas. A questão passa a ser: a regulação internacional aprofunda esse processo?

Algumas vertentes críticas têm buscado deslindar a incoerência econômica do direito internacional público. As estruturas de autoridade e a separação institucional de poderes públicos e privados são cruciais no estabelecimento de condições de fundo tanto para as economias nacionais quanto para a atividade econômica global. Ao mesmo tempo, o direito por trás da atividade econômica global é muito mais amplo do que o direito do comércio internacional. Direito privado, regulações locais, padrões industriais informais setor a setor, regulação administrativa pública, atos jurisdicionais, políticas corporativas internas e normas costumeiras de mercados ilegais também compõem o quadro normativo que incide sobre a atividade econômica. ${ }^{23}$ Assim, mais do que a divisão entre internacional e interno, o que se vê

\footnotetext{
${ }^{21}$ Debates. Revista da Associação Brasileira de Mantenedoras de Ensino Superior, v. 22, n. 33, Abr. 2004, p. 44-45.

${ }^{22}$ KENNEDY, David. Law and the Political Economy of the World, p. 12-13.

${ }^{23}$ KENNEDY, David. Law and the Political Economy of the World, p. 37-38.
} 
na educação superior é um direito muito mais amplo por trás da atividade econômica. Ele se aprofunda na década de 1990, com as mudanças na educação superior que acompanham a onda neoliberal e antecedem as regulações de direito do comércio internacional sobre a matéria, alcançando hoje regras em distintas esferas (regulação estatal, códigos de melhores práticas, regulações financeiras, normas domésticas dos países de origem dos investidores, etc.). Aparentemente, a influência desse ramo específico do direito é superestimada, ainda que o seu papel na construção das bases que incentivaram e garantiram a implementação quase generalizada de um direito liberal não seja menor.

Ainda assim, na visão de David Kennedy ${ }^{24}$, os internacionalistas pouco se atêm aos impactos distributivos das normas jurídicas locais, nacionais e internacionais na economia global, centrando seus esforços na tarefa de explicar como tais normas fazem parte de uma ordem jurídica coerente. A proposta do autor é engajar juristas internacionalistas em questões de economia política, focando sua ação na faixa intermediária entre ambas as áreas. A ideia seria usar a base do direito e do conhecimento específico jurídico como uma janela para interpretar o plano da ação da economia política mundial. Os juristas internacionalistas teriam um papel a cumprir, situando o direito internacional na política global e no sistema econômico mais amplo, como amálgama entre ideias avançadas e atrasadas, regiões ou setores econômicos, ou como a manta que esconde dinâmicas assimétricas de poder na econômica política do mundo. ${ }^{25}$ Sob todas essas formas, o direito internacional oferece um vocabulário normativo de direitos que constituem e estruturam relações entre atores, interesses e ideias que levam muitos à periferia e poucos ao centro do sistema. $^{26}$

Partindo do pressuposto de que esta é uma ordem cuja construção discursiva está alinhada com os interesses dos atores dominantes, tanto estatais quanto privados, a emergência de países como o Brasil no cenário internacional deve ser acompanhada por uma "agenda alternativa que problematize a ordem global e produza visão mais sofisticada de como o direito participa na construção assimétrica

\footnotetext{
${ }^{24}$ KENNEDY, David. Law and the Political Economy of the World, p. 26.

${ }^{25}$ KENNEDY, David. Law and the Political Economy of the World, p. 41.

${ }^{26}$ KENNEDY, David. Law and the Political Economy of the World, p. 42.
} 
do sistema internacional”. ${ }^{27}$ Isso significaria, além de priorizar negociações comerciais em áreas nas quais os países pobres tendem a ter vantagens comparativas, invocar "a ausência de conexões claras entre variáveis como abertura financeira e crescimento econômico para oferecer maior liberdade para os países implementarem políticas compatíveis com as suas necessidades", ${ }^{28}$ ao invés de replicar padrões estabelecidos pelos atores centrais do regime de comércio. Ao mesmo tempo em que a liberalização do comércio de serviços pode ter efeitos positivos sobre a dimensão liberal do direito à educação em relação à liberdade de ensino - o financiamento não discriminatório e o reconhecimento de diplomas, por exemplo -, a concorrência internacional acentuada pelos compromissos em serviços educacionais também orienta as políticas educacionais nacionais em matéria de garantia da qualidade, taxas escolares e pesquisa. ${ }^{29}$ Dessa forma, restringe a margem de manobra do Estado na realização da dimensão intervencionista do direito à educação, e mais precisamente na implementação de um direito de acesso em plena igualdade a um ensino superior de qualidade, sob o risco de acentuar o desenvolvimento de uma educação com níveis cada vez mais díspares de qualidade. ${ }^{30}$

\section{Apresentação do trabalho}

O processo de comercialização da educação acompanhou e se desenvolveu paralelamente à inclusão dos serviços educacionais nas negociações do GATS. Contudo, enquanto na OMC os serviços educacionais ainda constituem um dos setores com o menor número de compromissos de liberalização, no âmbito dos acordos preferenciais de comércio aprofundou-se a consolidação de compromissos de acesso a mercados e tratamento nacional na matéria, sobretudo nos acordos entre países desenvolvidos e países em desenvolvimento. Sob a perspectiva do direito do comércio internacional, a análise dos compromissos preferenciais acordados permite estabelecer com maior acerto um parâmetro do nível regulatório da liberalização comercial da educação superior, passível de ser comparado com o marco regulatório

\footnotetext{
${ }^{27}$ SOUZA, Igor Abdalla Medina de. O liberalismo interdisciplinar DI/RI no pós-Guerra Fria: Uma análise crítica, p. 38-39.

${ }^{28}$ SOUZA, Igor Abdalla Medina de. O liberalismo interdisciplinar DI/RI no pós-Guerra Fria: Uma análise crítica, p. 39.

${ }^{29}$ GROSBON, Sophie. Le droit à l'enseignement supérieur et la liberalisation international du commerce des services.

${ }^{30}$ GROSBON, Sophie. Le droit à l'enseignement supérieur et la liberalisation international $d u$ commerce des services.
} 
educacional brasileiro, no que diz respeito ao ingresso de capital estrangeiro e ao estabelecimento de instituições estrangeiras de ensino superior.

Assim, esta tese tem como objetivo analisar criticamente a pulsão regulatória do comércio internacional e sua compatibilidade com o direito à educação, bem como investigar as mudanças que a liberalização comercial dos serviços poderia trazer à regulação da educação superior no plano nacional. De um lado, sob a perspectiva doméstica, trata-se de evitar que a liberalização comercial dos serviços obste políticas de desenvolvimento e inclusão social ligadas à educação; de outro, sob a perspectiva internacional, trata-se de cotejar o direito do comércio internacional com um conjunto diferente de preocupações e valores a serem levados em consideração.

Esses objetivos desdobram-se em ao menos três hipóteses que foram testadas ao longo do trabalho. A primeira hipótese é a de que, mesmo sem acordos preferenciais de comércio, o mercado brasileiro já se encontra significativamente liberalizado no que diz respeito aos investimentos estrangeiros em educação superior, sem qualquer restrição ao ingresso de capital internacional, tanto na aquisição de instituições domésticas quanto na participação societária em empresas educacionais nacionais. A segunda hipótese é de que as posições contrárias ao GATS usualmente superestimam o seu papel na comercialização da educação superior, enquanto as posições favoráveis a acordos comerciais na matéria possuem bases frágeis, lastreadas em um conceito bastante abstrato de "flexibilidade". Por fim, é analisada a hipótese de que a regulação internacional do comércio de serviços aprofundaria esse processo, principalmente a partir da ideia de consolidação do marco regulatório liberal doméstico e de mecanismos que conduzem à aceleração do processo de liberalização comercial.

Nesse sentido, a primeira parte da tese foi desenvolvida por meio da análise de entrevistas realizadas com professores e gestores de instituições de ensino superior adquiridas por grupos educacionais estrangeiros ou por grupos educacionais brasileiros com capital aberto na bolsa de valores; com consultores do setor privado educacional e com um Deputado Federal, autor de projeto de lei que proíbe o capital estrangeiro nas instituições de ensino no Brasil. O objetivo principal é avaliar a percepção dos atores em relação ao processo de comercialização da educação superior 
no Brasil, suas características principais e a influência que sofre ou não de elementos internacionais, tais como capital, gestão e normas.

Assim, o capítulo 1 foi estruturado a partir dos principais pontos levantados pelos entrevistados em relação ao setor educacional privado com fins lucrativos: expansão do ensino superior privado; a gestão acadêmica em relação à gestão empresarial; a relação entre o professor e o aluno como cliente/consumidor; padronização; investimentos em pesquisa e pós-graduação stricto sensu; precarização da docência; os grandes grupos educacionais e o ensino de massa; a influência do direito internacional e o controle sobre a participação do capital estrangeiro. Sem pretensões de cobrir exaustivamente cada tópico, o capítulo contrapõe as percepções oferecidas pelos atores entrevistados, muito diversas ainda que eventualmente eles integrem um mesmo grupo educacional. Ao fim, são rapidamente apresentadas as principais regras que se aplicam às instituições de ensino superior, estejam elas sob controle nacional ou sob controle estrangeiro.

Na sequência, a inserção da educação superior em uma dinâmica de comércio internacional exige a compreensão do funcionamento das regras neste campo e também do processo de negociação de temas regulatórios essencialmente ligados a direitos humanos em negociações de comércio. Dessa forma, o capítulo 2 apresenta primeiramente a educação superior como um bem público e direito humano, e sua inclusão em uma lógica comercial, considerando também as relações possíveis entre os regimes de direitos humanos e de comércio internacional. A seguir, é trabalhada a regulação multilateral do comércio de serviços e suas características centrais, especialmente sob a perspectiva dos serviços educacionais, seguido da condução das negociações em torno do comércio de serviços do multilateralismo para os acordos preferenciais de comércio, apresentando os elementos de sua regulação que os diferenciam das regras multilaterais. Por último, é analisado o processo negociador em matéria de serviços educacionais, sobretudo a definição das posições negociadoras entre o regulador educacional e o negociador comercial, e a complexidade da relação entre ambos, considerando principalmente o cenário brasileiro.

Finalmente, a análise dos principais acordos de comércio dos países mais envolvidos com a regulação do comércio de serviços oferece uma alternativa aos compromissos assumidos no GATS para mapear os novos passos regulatórios dados 
em matéria de serviços educacionais. Sendo assim, o capítulo 3 traz as disciplinas sobre o comércio de serviços, investimentos e os compromissos específicos e limitações/reservas em educação superior em cerca de 40 acordos de comércio, assinados posteriormente ao ano 2000, obedecendo a critérios regionais e, dentro do universo de países que têm optado pela via dos acordos de comércio, a possíveis abordagens distintas nos modelos de liberalização comercial na matéria. São eles: Estados Unidos e Austrália, grandes exportadores de serviços educacionais e fomentadores da liberalização comercial no setor; China e Índia, os principais países em desenvolvimento com acordos assinados na matéria e com crescente interesse na liberalização do setor educacional; Cingapura, que há mais de dez anos volta sua política para a consolidação do país como um polo educacional; Chile, país latinoamericano, com um papel predominante do setor privado na educação doméstica e ativamente envolvido em negociações de acordos de comércio, junto com o Peru e, recentemente, a Colômbia; e, por fim, a União Europeia, com suas diferenças internas ao bloco e distintas abordagens dos Estados membros. Os acordos analisados formam uma grande rede regulatória em matéria de serviços e, especificamente, serviços educacionais, não só porque vários deles foram assinados entre os países ora elencados, mas também porque foram assinados com outros parceiros em comum, com destaque para o Peru, Coreia do Sul, Colômbia, Malásia e Nova Zelândia. Tais características permitem estabelecer um parâmetro do que tem sido a liberalização comercial no setor, passível de ser comparado com o marco regulatório brasileiro, de forma a compreender os riscos e desafios que poderão ser impostos à regulação doméstica do setor da educação superior, ao mesmo tempo em que abre espaço para questionar a existência ou não de um processo de governança internacional na regulação comercial da educação superior. 


\section{A EDUCAÇÃO SUPERIOR PRIVADA COM FINS LUCRATIVOS: UMA VISÃO DOS ATORES SOBRE A EXPANSÃO DO SETOR}

\subsection{Justificativa para a escolha de uma abordagem metodológica qualitativa}

A metodologia utilizada na elaboração deste capítulo é baseada em pesquisa empírica de cunho qualitativo, mediante a realização de entrevistas exploratórias, por instrumento semiestruturado, com professores e gestores de instituições de ensino superior que foram adquiridas por grupos educacionais estrangeiros ou por grupos educacionais brasileiros com capital aberto na Bolsa de Valores, e com consultores do setor privado educacional. São diferentes atores cuja opinião mobiliza variáveis que interessam ao problema principal do trabalho. Portanto, o método qualitativo oferece melhores resultados quando se trata de conhecer com maior profundidade fenômenos complexos, e pôr à prova a pertinência das hipóteses. $^{31}$

A opção pelas entrevistas semiestruturadas assegurou maior flexibilidade na condução das mesmas. Sob a perspectiva epistemológica, a entrevista permite apreender a experiência dos outros, mas também elucidar suas condutas. ${ }^{32}$ Dessa forma, "além de suas próprias interpretações, o pesquisador se encontra, portanto, diante não de uma, mas de várias interpretações de uma mesma realidade, já que cada pessoa ou grupo é capaz de dar uma interpretação diferente sobre ela" ${ }^{33}$

No plano metodológico, o entrevistado é tido como um informantechave sobre as suas próprias práticas e maneiras de pensar e também sobre o seu

\footnotetext{
${ }^{31}$ DESLAURIERS, Jean-Pierre. O delineamento de pesquisa qualitativa. In: POUPART, Jean; DESLAURIERS, Jean-Pierre; GROULX, Lionel-H; LAPERRIÈRE, Anne; MAYER, Robert; PIRES, Álvaro. A pesquisa qualitativa: enfoques epistemológicos e metodológicos. Tradução de Ana Cristina Arantes Nasser. Petrópolis, RJ: Vozes, 2012, p. 129-130.

32 POUPART, Jean. A entrevista de tipo qualitativa: considerações epistemológicas, teóricas e metodológicas. In: POUPART, Jean; DESLAURIERS, Jean-Pierre; GROULX, Lionel-H; LAPERRIÈRE, Anne; MAYER, Robert; PIRES, Álvaro. A pesquisa qualitativa: enfoques epistemológicos e metodológicos. Tradução de Ana Cristina Arantes Nasser. Petrópolis, RJ: Vozes, 2012, p. 216.

${ }^{33}$ POUPART, Jean. A entrevista de tipo qualitativa: considerações epistemológicas, teóricas e metodológicas, p. 218.
} 
meio, considerando sua posição como "representativa" de seu grupo. ${ }^{34} \mathrm{O}$ trabalho procura compreender as preocupações dos atores sociais entrevistados, tal como vividas no cotidiano, ${ }^{35}$ tanto no ambiente de sala de aula quanto no da cultura organizacional da instituição, que varia segundo a função desempenhada pelo entrevistado. Essa abordagem favorece a descrição dos fenômenos sociais, mas também a sua explicação e a compreensão de sua totalidade ${ }^{36} \cdot 37$

Resta evidente a interação entre perguntas, respostas e contexto social, pelo que não se buscou a padronização e se evitou a diretividade. A entrevista semiestruturada, "ao mesmo tempo que valoriza a presença do investigador, oferece todas as perspectivas possíveis para que o informante alcance a liberdade e a espontaneidade necessárias". ${ }^{38}$ A partir de determinados questionamentos básicos, apoiados em teorias e hipóteses, coloca-se na sequência a possibilidade de um amplo espaço para novas interrogações que vão surgindo ao receber as respostas dos entrevistados. ${ }^{39}$ A realização de perguntas complementares para entender melhor o fenômeno em questão está aliada também à flexibilidade na sequência da apresentação das perguntas ao entrevistado prevista no roteiro original, enriquecendo a investigação. $^{40}$

Interessam à pesquisa as regularidades entre as entrevistas, que permitem traçar um perfil mais amplo do setor que se procurar entender, mas sobretudo as irregularidades e o quanto o contexto específico do entrevistado diz

\footnotetext{
${ }^{34}$ POUPART, Jean. A entrevista de tipo qualitativa: considerações epistemológicas, teóricas e metodológicas, p. 222.

${ }^{35}$ DESLAURIERS, Jean-Pierre. O delineamento de pesquisa qualitative, p. 130.

${ }^{36}$ TRIVIÑOS, Augusto N. S. Introdução à pesquisa em ciências sociais: a pesquisa qualitativa em educação. São Paulo: Editora Atlas, 1987, p. 152.

${ }^{37}$ Stephen Ball, ao tentar mapear a privatização do ensino superior no Reino Unido e as relações entre as companhias do que ele chama de "indústria dos serviços educacionais", realizou entrevistas com executivos destas empresas. Uma das primeiras conclusões do autor é que, em razão da natureza dos questionamentos apresentados por ele, as entrevistas com esse atores da privatização também foram em parte narrativas de histórias pessoais. Logo, segundo o autor, o setor privado é constituído por relações, conflitos e personalidades, e a origem dos principais executivos dos grupos educacionais (setor financeiro, setor educacional público, etc.) diz muito sobre quem eles são, ajudando também a moldar o perfil da própria empresa. Também em função das perguntas apresentadas e da própria abertura que a entrevista semiestruturada proporciona, os relatos dos entrevistados mesclavam considerações pessoais, sobre aspectos éticos e sensibilidades políticas, ao mesmo tempo em que representavam e, em diferentes medidas, defendiam a sua companhia e o próprio setor privado (BALL, Stephen J. Education $p l c$ : Understanding private sector participation in public sector education, p. 12).

${ }^{38}$ TRIVIÑOS, Augusto N. S. Introdução à pesquisa em ciências sociais: a pesquisa qualitativa em educação, p. 146.

${ }^{39}$ TRIVIÑOS, Augusto N. S. Introdução à pesquisa em ciências sociais: a pesquisa qualitativa em educação, p. 146.

${ }^{40}$ MANZINI, Eduardo José. Uso da Entrevista em Dissertações e Teses produzidas em um Programa de Pós-graduação em Educação, Revista Percurso - NEMO, v. 4, n. 2, 2012, p. 156.
} 
sobre a maneira como ele concebe o cenário em que se encontra inserido e sobre o qual é questionado. ${ }^{41}$ São fundamentais para a pesquisa as crises que se estabelecem em um momento de mudança social, eis que as instituições onde os entrevistados atuam foram adquiridas ou adquiriram outras instituições de educação superior.

A análise dos dados deu-se primeiramente pela decomposição vertical e horizontal das entrevistas, com o posterior cruzamento entre todas elas, a partir da delimitação dos pontos convergentes e divergentes. ${ }^{42}$ A revisão bibliográfica sobre os fenômenos considerados e a análise documental são trabalhadas conjuntamente com o conteúdo das entrevistas, com o intuito de auxiliar na elucidação da análise dos dados. Procura-se, assim, com o tratamento conjunto, manter um equilíbrio entre o trabalho empírico e o trabalho teórico, confrontando constantemente as categorias e relações da pesquisa aos dados, de modo que se possa recorrer a todos os trabalhos julgados pertinentes, mas sem tornar-se dependente de nenhum deles. ${ }^{43}$

\subsection{Delimitação das entrevistas: atores e questionamentos}

No período entre dezembro de 2012 e dezembro de 2013 foram realizadas 12 entrevistas. Dessas, 8 foram presenciais - 5 com permissão para serem gravadas e posteriormente transcritas ${ }^{44}$ - e 4 foram concedidas por meio eletrônico, após o envio prévio do roteiro de perguntas. Esse universo de pesquisa contempla 4 professores, 1 Pró-Reitor, 1 diretor de curso, 1 coordenador de curso, 1 gestor, 1 Reitor/presidente de associação do setor educacional privado, 2 consultores do setor educacional privado e 1 deputado federal. Na medida do possível, procurou-se garantir a diversidade institucional e a representatividade regional. Todos os entrevistados presencialmente assinaram termos de confidencialidade e, assim, suas identidades e as instituições que representam foram preservadas. Das 4 entrevistas

\footnotetext{
${ }^{41}$ POUPART, Jean. A entrevista de tipo qualitativa: considerações epistemológicas, teóricas e metodológicas, p. 241.

${ }^{42}$ ALMEIDA, Wilson Mesquita de. Ampliação do Acesso ao Ensino Superior Privado Lucrativo Brasileiro: um Estudo Sociológico com Bolsistas do Prouni na Cidade de São Paulo. Tese (Doutorado em Sociologia). Universidade de São Paulo, 2012, p. 101.

${ }^{43}$ DESLAURIERS, Jean-Pierre. O delineamento de pesquisa qualitative, p. 137-149.

${ }^{44}$ As transcrições foram realizadas pelo autor, respeitando os termos exatos de que fizeram uso os entrevistados. Salvo pequenos trechos que fugiram completamente ao objeto da pesquisa - caso de anedotas ou histórias estranhas aos pontos estudados -, a transcrição foi integral e contou com o auxílio de anotações complementares pelo autor.
} 
realizadas por meio eletrônico, por opção do autor, a identidade do entrevistado somente é revelada, com permissão destes, nos casos da entrevista com o professor Gabriel Mário Rodrigues, Presidente da Associação Brasileira de Mantenedoras de Educação Superior (ABMES) e Secretário Executivo do Fórum das Entidades Representativas do Ensino Superior Particular, e da entrevista com o Deputado Federal Ivan Valente (PSOL/SP), autor de projeto de lei que proíbe o capital estrangeiro nas instituições de ensino no Brasil. Quanto aos outros dois entrevistados, consultores do setor privado, mantém-se a confidencialidade.

Além das entrevistas efetivamente realizadas, deve ser ressaltado que foram incansavelmente procurados - pelo candidato e pela orientadora, além de gestores de outras pastas de governo que se dispuseram a auxiliar na pesquisa representantes da Secretaria de Regulação e Supervisão da Educação Superior (SERES/MEC), da Secretaria de Educação Superior (SESU/MEC), do Conselho Administrativo de Defesa Econômica (CADE), de sindicatos ligados ao setor público educacional, de consultorias privadas, bem como outros professores e gestores de instituições adquiridas por grupos educacionais estrangeiros ou grupos educacionais nacionais com capital aberto na bolsa de valores. Tais solicitações de entrevistas ou jamais foram respondidas, ou deixaram de ser respondidas quando já se encaminhava a realização de entrevistas. De todo o modo, na tentativa de contemplar as perspectivas dos órgãos e instituições os quais representam, o trabalho inclui depoimentos e posições desses atores colhidos em artigos científicos, palestras e entrevistas a terceiros.

Com exceção dos consultores e do diretor de curso de um grupo educacional brasileiro, os demais entrevistados eram no momento da entrevista contratados de instituições de ensino superior recém adquiridas por grupos educacionais domésticos com capital aberto na bolsa de valores ou por grupos educacionais estrangeiros. O tamanho do grupo e o fato de pertencerem a um mesmo setor potencializaram referências cruzadas entre as entrevistas, determinando um processo cumulativo. Em especial, alguns dos atores trabalharam tanto em instituições adquiridas por grupos nacionais quanto em instituições adquiridas por grupos estrangeiros, enquanto outros já cumpriram ou ainda cumprem funções de avaliadores ad hoc junto ao MEC. Dessa forma, parte dos depoimentos permitiu uma análise comparada dessas instituições pela perspectiva de um mesmo ator, oferecendo leituras 
críticas sobre as condições e os modelos educacionais com os quais se depararam quando da mudança de instituição e como avaliadores.

A partir de um núcleo comum de perguntas, o roteiro das entrevistas foi adaptado às funções desempenhadas pelos atores em suas respectivas instituições de ensino, a fim de compreender sua percepção sobre o processo corrente de comercialização da educação superior, à transição em suas instituições recém adquiridas por um grupo educacional nacional ou estrangeiro, e ao reconhecimento ou não de elementos internacionais nesse processo - capital, gestão e normas. ${ }^{45}$ Assim, as principais perguntas que nortearam as entrevistas se concentram na relação entre a gestão empresarial e a gestão acadêmica estabelecida após a aquisição da respectiva instituição por um grupo educacional - doméstico ou estrangeiro; na comparação entre os períodos anterior e posterior ao processo de fusões e aquisições no ensino superior no Brasil, considerando qualidade do ensino, práticas pedagógicas e valorização do professor; na relação entre o chamado ensino de massa e a qualidade educacional; no papel do capital estrangeiro no processo de consolidação do setor da educação superior; e na repercussão de normativas internacionais sobre as aquisições de instituições de ensino superior e sobre a gestão das mesmas. Aos consultores do setor privado, também foram apresentadas questões sobre um eventual controle sobre a presença de investidores estrangeiros no setor educacional. Ao Deputado Federal Ivan Valente, por sua vez, foram dirigidos questionamentos sobre a viabilidade de projetos de lei que proíbem ou limitam a presença de capital estrangeiro, e a capacidade de influência das entidades representativas do setor privado junto à Comissão de Educação da Câmara dos Deputados.

A maneira como as entrevistas foram conduzidas e a forma como evoluíram evidenciam uma tentativa de não utiliza-las tão somente como um reservatório de dados. A pesquisa qualitativa enfatiza o campo também como uma fonte de novas questões ${ }^{46}$. Nesse sentido, a realização das entrevistas foi decisiva para a formulação de novas questões, a fim de incluir variáveis que não estavam previstas

\footnotetext{
45 “A composição do roteiro por meio de perguntas é importante para vários motivos. Primeiro porque é possível preparar a configuração das perguntas e adequá-las para o nível de linguagem dos participantes. Além disso, é importante que todas as perguntas, que se relacionam a itens e conceitos a serem pesquisados (GÜNTHER, 1999), sejam realmente feitas durante a entrevista, uma vez que a comparação de respostas na entrevista semiestruturada é requerida na análise" (MANZINI, Eduardo José. Uso da Entrevista em Dissertações e Teses produzidas em um Programa de Pós-graduação em Educação, p. 157).

${ }^{46}$ DESLAURIERS, Jean-Pierre. O delineamento de pesquisa qualitativae, p. 147-148.
} 
no esboço das entrevistas iniciais e descartar outras, menos pertinentes. Por conseguinte, informações e percepções de uma entrevista puderam ser sondadas ou verificadas na próxima, em uma dinâmica de aprendizado e acumulação de conhecimentos sobre áreas técnicas, buscando compreender a cultura do setor privado. $^{47}$

Por vezes induzidos pelo roteiro de perguntas, por vezes de maneira espontânea, os entrevistados em geral usaram como parâmetro de comparação a prática que se reputa aos demais grupos educacionais, quase sempre em uma oposição entre Anhanguera Educacional, Kroton Educacional e Estácio e os principais grupos educacionais estrangeiros com presença no Brasil - Laureate Brasil, Whitney International e DeVry Brasil. ${ }^{48}$ Essa hipótese - diferenças entre os grupos domésticos e os estrangeiros - surgiu durante o processo de entrevistas e passou a ser incorporada e testada nas entrevistas seguintes. Ao longo das entrevistas evidenciou-se igualmente uma oposição entre as perspectivas de professores, de um lado, e de gestores, de outro, sobre os mesmos fenômenos, ainda que eventualmente partes de um mesmo grupo educacional. Essas duas "oposições", presentes em praticamente todas as entrevistas realizadas, foram incorporadas ao trabalho.

\subsection{Expansão do ensino superior privado}

A especificidade do sistema de educação superior brasileiro em relação a outros países da América Latina e da Europa, onde havia até o final da década de 1980 um sistema de educação superior concentrado em universidades públicas e universidades católicas, total ou parcialmente dependentes de recursos públicos, emerge de ao menos duas formas. Primeiramente, no Brasil, as universidades constituíam, até os anos 1980, uma fração menor do ensino superior; em segundo lugar, e o que é mais importante para esse trabalho, nos anos 1960 proliferou no país um segmento não-confessional e não-universitário, cujas instituições organizadas

\footnotetext{
${ }^{47}$ BALL, Stephen J. Education plc: Understanding private sector participation in public sector education, p. 12.

${ }^{48}$ No momento da realização das entrevistas os grupos educacionais de ensino superior do setor privado com fins lucrativos estavam representados pela Anhanguera Educacional, pela Kroton Educacional e pelo Grupo Estácio. No decorrer de 2013, houve a fusão entre Anhanguera e Kroton e a abertura de capital na Bolsa de Valores dos grupos Ânima e Ser Educacional.
} 
como empresas buscavam como objetivo primordial a obtenção de lucro, ainda que eventualmente de maneira não explícita, dadas as limitações impostas pela legislação do período ${ }^{49}$.

Embora estruturadas como um negócio, até 1996 não havia regulamentação para empresas educacionais, que compunham o segmento privado ao lado das instituições confessionais, das instituições comunitárias e de escolas superiores sem fins lucrativos organizadas por elites locais, todas classificadas como instituições sem fins lucrativos, assim beneficiadas pela renúncia fiscal e pelo acesso a recursos federais. ${ }^{50}$ Regulamentadas em conjunto, formavam, na verdade, um sistema privado no qual um segmento se assemelhava ao setor público e outro segmento assumia características empresariais. A partir de então, o crescimento do último dominou o setor privado da educação superior e hoje concentra as discussões sobre profissionalização da gestão, fusões e aquisições, aportes de fundos de investimentos, ensino de massa e acesso à educação superior.

Gabriel Mário Rodrigues, presidente da Associação Brasileira de Mantenedoras de Ensino Superior, em um panorama geral, descreve o desenvolvimento desse segmento empresarial no sistema de educação superior no Brasil:

\begin{abstract}
"O ensino superior particular brasileiro praticamente começou a dar seus passos mais expressivos na década de 60 do século passado, quando, para atender a demanda de alunos que desejavam ingressar na universidade, o governo (militar) da época usou a estratégia de promover a educação superior por meio da iniciativa particular, pois o Estado não tinha condições de fazê-lo. Era a época dos célebres excedentes. Alunos que prestavam vestibular nas instituições públicas eram aprovados, mas não encontravam vagas disponíveis para fazerem seus cursos. $O$ país começava a desenvolver-se pela industrialização, carecia de recursos humanos para fazer face ao seu crescimento, a mulher retornava aos estudos por busca de melhor formação e ingressar com mais preparo no mercado de trabalho, como também, quem trabalhava, procurava pela formação superior, ter mais chances na empresa. Consequência de tudo isto foi ter uma demanda incontida (classe média/alta) procurando as faculdades que estavam sendo criadas, no início nas capitais e cidades mais importantes e depois pelo Brasil afora.
\end{abstract}

\footnotetext{
${ }^{49}$ DURHAM, Eunice R. Educação superior, pública e privada. In: BROCK, Colin; SCHWARTZMAN, Simon. Os desafios da educação no Brasil. Rio de Janeiro: Nova Fronteira, 2005, p. 192.

${ }^{50}$ CARVALHO, Cristina Helena Almeida de. A política pública para a educação superior no Brasil (1995-2008): ruptura e/ou continuidade? Tese (Doutorado em Ciências Econômicas). Universidade Estadual de Campinas, 2011, p. 3.
} 
Primeiro Brasil Sul, Sudeste e a partir dos anos 90, o Centro, Norte e Nordeste. Embora as instituições confessionais já oferecessem em algumas capitais cursos superiores, o vetor do desenvolvimento cresceu graças aos empreendedores educacionais particulares. Grupos familiares que já possuíam colégios e outros profissionais perceberam no ensino uma oportunidade de empreender e a seu risco e ousadia começaram a criar faculdades por este Brasil afora."

(...)

"O crescimento do sistema educacional brasileiro foi relativamente homogêneo até o final dos anos 1990. O desenvolvimento das instituições deu-se de forma constante e beneficiado pela demanda natural dos alunos que ingressariam num curso superior. A concorrência entre instituições era pequena e os resultados econômicos eram usados nas construções e instalações de laboratórios e bibliotecas para atender a expansão. Como os proprietários eram grupos familiares ou de sócios amigos e o reinvestimento no próprio negócio era natural e o crescimento do empreendimento. Os anos 2000 mudaram esta concepção com uma concorrência muito grande por alunos e com uma profissionalização e com ações mais focadas em resultados. As instituições começaram a se consolidar e planejar para ganharem mercado."51

Diferentes fases deste percurso podem ser classificadas em períodos específicos considerando a sequência de políticas educacionais e as características que o sistema vai assumindo. Assim, o predomínio das instituições privadas no Brasil teve início “com a Reforma Universitária de 1968 implementada durante o Regime Militar, que incentivou o surgimento e a manutenção, em princípio, de estabelecimentos isolados". ${ }^{52}$ Essa fase corresponderia a um primeiro período, que se estende até 1975, com o predomínio de faculdades isoladas de pequeno porte, seguido de um segundo período que vai até meados dos anos 1980 e se caracteriza pelo agrupamento das instituições em federações de escolas. Por fim, o terceiro período abarca tanto a segunda metade da década de 1980, com a transformação das federações de escolas em universidades "para adquirir autonomia e fugir dos controles do Conselho Federal de Educação" ${ }^{\text {53 }}$, como o interregno dos anos 2000 até hoje, representado pelo intenso processo de fusões e aquisições no setor educacional

\footnotetext{
${ }^{51}$ RODRIGUES, Gabriel Mário (Presidente da Associação Brasileira de Mantenedoras de Ensino Superior). Entrevistador: Lucas da Silva Tasquetto, 18 Mar. 2013.

${ }^{52}$ CARVALHO, Cristina Helena Almeida de. A política pública para a educação superior no Brasil (1995-2008): ruptura e/ou continuidade?, p. 3.

${ }^{53}$ DURHAM, Eunice R. Educação superior, pública e privada, p. 215.
} 
superior, apoiado na crescente participação de fundos de investimento, domésticos e estrangeiros. $^{54}$

Entre 1960 e 1980 foi atribuída ao setor privado a tarefa de expandir o número de vagas oferecidas no ensino superior, atendendo a uma demanda crescente. Em 20 anos, "o número de matrículas de ensino superior passou de 200 mil para 1,4 milhão, em um crescimento de quase $500 \%$. No setor privado, o crescimento foi de mais de $800 \% " 55$. Com isso, é deixado de lado o relativo equilíbrio que caracterizava até então a relação público e privado na educação superior brasileira, não só em termos de instituições, mas também de matrículas. ${ }^{56}$ A expansão do setor educacional empresarial respondeu aos componentes mais imediatos da demanda social, concentrada na obtenção de um diploma ${ }^{57}$, e se tornou viável graças à oferta de cursos de baixo custo e à imposição de exigências acadêmicas brandas para o ingresso e avanço dos alunos nos cursos até a graduação. ${ }^{58}$ Assim, as políticas educacionais desse período abriram espaço para uma divisão de funções no setor da educação superior, no qual concedeu-se às universidades públicas a função de gerar pesquisa científica e tecnológica avançada $^{59}$, acarretando uma combinação perversa entre um sistema público de alto nível e a hegemonia de instituições privadas de baixa qualidade. $^{60}$

Embora o depoimento do presidente da ABMES descreva certa estabilidade no desenvolvimento do setor privado até o final dos anos de 1990, houve

\footnotetext{
${ }^{54}$ ALMEIDA, Wilson Mesquita de. Ampliação do Acesso ao Ensino Superior Privado Lucrativo Brasileiro: um Estudo Sociológico com Bolsistas do Prouni na Cidade de São Paulo, p. 47.

${ }^{55}$ SAMPAIO, Helena. Ensino superior privado: reprodução e inovação no padrão de crescimento, Revista da Associação Brasileira de Mantenedoras de Ensino Superior, v.27, n.39, Dez. 2009, p. 47.

${ }^{56}$ SAMPAIO, Helena. O Setor Privado de Ensino Superior no Brasil: Continuidades e Transformações. Revista Ensino Superior Unicamp, n. 4, Out. 2011, p. 29.

${ }^{57}$ Para Durham, "essa tendência é reforçada por uma longa tradição cartorial da sociedade brasileira, que associa diploma de ensino superior ao acesso a uma profissão regulamentada e assegura a seus portadores nichos privilegiados no mercado de trabalho. Nesse contexto, podem ser lucrativos estabelecimentos de ensino nos quais a qualidade da formação oferecida é de importância secundária" (DURHAM, Eunice R. Educação superior, pública e privada, p. 210).

${ }^{58}$ DURHAM, Eunice R. Educação superior, pública e privada, p. 209-210.

${ }^{59}$ Segundo Altbach, Reisberg e Rumbley, não só o Brasil, mas uma série de outros países, em especial Japão, Coreia do Sul, Filipinas, Indonésia e outros da América Latina e do Leste da Ásia, mantiveram o setor educacional público pequeno e seletivo relativamente ao setor privado, transferindo aos pais e estudantes os custos da expansão, por meio do encorajamento ao crescente setor privado de educação superior (ALTBACH, Philip G.; REISBERG, Liz; RUMBLEY, Laura E. Trends in Global Higher Education: Tracking an Academic Revolution - A Report Prepared for the UNESCO 2009 World Conference on Higher Education. Paris: UNESCO, 2009, p. xi).

${ }^{60}$ TRINDADE, Hélgio. O ensino superior na América Latina: um olhar longitudinal e comparativo. In: TRINDADE, Hélgio; BLANQUER, Jean-Michel. Os desafios da educação na América Latina. Petrópolis: Editora Vozes, 2002, p. 27.
} 
um momento de inflexão no número de matrículas nos anos 1980, com taxas de crescimento que não chegaram a $1 \%$ na primeira metade da década ${ }^{61}$, de forma que a retomada da expansão das universidades privadas a partir de 1985 ocorre sobretudo pela pressão do setor lucrativo voltado para o ensino de massa, sem maior atenção à qualificação do corpo docente e à pesquisa. ${ }^{62}$

A literatura indica, porém, diferentes períodos na trajetória do ensino superior privado no Brasil. É possível encontrar conceitos em relação ao segmento privado muito próximos aos trazidos por Gabriel Mário Rodrigues em sua entrevista "oportunidade de empreender", "risco" e "ousadia" -, ainda que este se refira ao período inicial da expansão privada ${ }^{63}$. Assim, o período entre 1891 e 1960 seria o da consolidação do setor; em seguida, haveria o segundo período, correspondente a uma grande expansão entre 1960 e 1980, para, enfim, a meados dos anos 1980, emergir o momento de "reação criativa" frente à desaceleração do crescimento, quando a iniciativa privada deixa de responder à pressão por educação superior e, antecipandose à demanda, passa a organizar e orientar a oferta. Nesta abordagem, o final do século do XX seria de "viração", em uma lógica de sobrevivência criativa ao lidar, de um lado, com um Estado regulador, expedidor de disposições legais e normas burocráticas, e, de outro, um mercado em desaceleração. ${ }^{64}$

Segundo Helena Sampaio, três eixos de "reações empreendedoras" viriam a configurar o setor privado no início dos anos 1990: i) rápida transformação dos estabelecimentos isolados em universidades, se valendo da prerrogativa de "universidade" para que seus gestores pudessem interagir mais agilmente com a demanda $^{65}$; ii) desconcentração regional e interiorização das matrículas privadas, em direção especialmente às regiões Norte e Centro-Oeste; e iii) crescimento acelerado do número de cursos e ampliação das carreiras oferecidas, sobretudo com a fragmentação das carreiras nas regiões Sudeste e Sul, conforme a autora, "um

\footnotetext{
${ }^{61}$ Por exemplo, SAMPAIO, Helena. Ensino superior privado: reprodução e inovação no padrão de crescimento, p. 48.

${ }^{62}$ DURHAM, Eunice R. Educação superior, pública e privada, p. 215.

${ }^{63}$ SAMPAIO, Helena. Ensino superior privado: reprodução e inovação no padrão de crescimento, p. 46-48.

${ }^{64}$ SAMPAIO, Helena. O Setor Privado de Ensino Superior no Brasil: Continuidades e Transformações, p. 30.

65 “Ao disciplinar o princípio de autonomia para as universidades, a Constituição criou um instrumento que abriu para o setor privado a possibilidade de se liberar do controle burocrático do Conselho Federal da Educação, especialmente no que diz respeito à criação e extinção de cursos na sede e ao remanejamento do número de vagas oferecidas" (SAMPAIO, Helena. Ensino superior privado: reprodução e inovação no padrão de crescimento, p. 48).
} 
movimento dinâmico, incessante; orientado pelo e para o mercado, com os objetivos de ampliar e diversificar a clientela." 66

Os discursos que tendem a enaltecer o empreendedorismo privado na educação superior, cujo crescimento dar-se-ia não só independentemente do Estado, mas às vezes apesar deste, considerando o seu papel como regulador, ignoram o financiamento indireto público desde o início do surto expansivo das instituições particulares de ensino. Nesse sentido,

\begin{abstract}
"a estratégia de financiamento público foi bastante clara: a queda na participação dos gastos do Ministério da Educação (MEC) no orçamento da União, apesar do período compreendido pelo milagre econômico (1968/1973), ocorreu de forma concomitante ao acréscimo de mecanismos indiretos de recursos públicos direcionados à oferta por meio da renúncia fiscal, concedida às instituições particulares, bem como à demanda, através da concessão de crédito educativo aos estudantes destes estabelecimentos. Associado a isto, é relevante acrescentar o papel desempenhado pelo Conselho Federal de Educação, responsável pela autorização de funcionamento de instituições e cursos, cujos critérios foram relaxados ao longo do regime militar". ${ }^{67}$
\end{abstract}

Ausente a diferenciação institucional no seio do segmento privado, e não prevista pela legislação a figura da instituição de ensino com fins lucrativos, praticamente todos os estabelecimentos privados de ensino superior deixavam de recolher impostos sobre patrimônio, renda e serviços. Sem poder distribuir lucros, como revela a já citada entrevista com o presidente da ABMES, todo resultado econômico positivo devia ser usado "nas construções e instalações de laboratórios e bibliotecas para atender a expansão" 68 , ou seja, reinvestidos nos próprios estabelecimentos, garantindo no mínimo uma acumulação patrimonial significativa. ${ }^{69}$ Posto que nunca se conseguiu controlar efetivamente essas operações, a distribuição de lucros dava-se continuamente por meio de subterfúgios, como salários muito altos concedidos a membros da mantenedora em cargos de direção, desvio de recursos para

\footnotetext{
${ }^{66}$ SAMPAIO, Helena. Ensino superior privado: reprodução e inovação no padrão de crescimento, p. 49.

${ }^{67}$ CARVALHO, Cristina Helena Almeida de. A política pública para a educação superior no Brasil (1995-2008): ruptura e/ou continuidade?, p. 1.

${ }^{68}$ RODRIGUES, Gabriel Mário (Presidente da Associação Brasileira de Mantenedoras de Ensino Superior).

${ }^{69}$ ALMEIDA, Wilson Mesquita de. Ampliação do Acesso ao Ensino Superior Privado Lucrativo Brasileiro: um Estudo Sociológico com Bolsistas do Prouni na Cidade de São Paulo, p. 38.
} 
outros empreendimentos e uso particular dos mantenedores para despesas pessoais cotidianas e luxos. $^{70}$

Nesses termos, as isenções fiscais representaram desde então um instrumento fundamental de direcionamento de recursos do Estado para o segmento privado, em uma situação que "ocultou o avanço no crescimento de grandes estabelecimentos mercantis aglutinados em universidades" ${ }^{\text {71 }}$ e se estendeu até logo depois da promulgação da Lei de Diretrizes e Bases (LDB), em 1996, que discriminou instituições sem fins lucrativos e as que visam ao lucro. Ainda assim, estabelecimentos como a Estácio de Sá, hoje consolidada como um dos maiores grupos educacionais no país, permaneceram na condição de entidades filantrópicas sem fins lucrativos até 2007, após um longo processo de expansão assegurado sob isenções fiscais e previdenciárias. ${ }^{72}$

Essa transição na qual os estabelecimentos educacionais lucrativos passaram a dever ser reconhecidos como tal, sem os privilégios a que faziam jus anteriormente, corresponde nas entrevistas realizadas com gestores do setor privado à emergência da ideia de gestão profissional:

"por outro lado na década inicial deste século há maior concorrência entre as IES, há necessidade de maior profissionalização da gestão e tendência natural de concentração para diminuição de custos, da segurança, da tecnologia e dos imóveis. Não há mais oportunidade para o amadorismo dos tempos iniciais e também os primeiros empreendedores da área já completaram setenta anos. Constatação real; dirigir escolas dá muito trabalho e nem sempre há sucessores para dar continuidade aos negócios.,73

O Entrevistado 02, Diretor de Curso de Grupo nacional A, credita à perda das isenções tributárias a redução das margens de lucro e um alto nível de inadimplência das instituições privadas, que conduziriam à necessidade de uma gestão profissionalizada. Esta chegou sobretudo com a abertura do capital do grupo na bolsa

\footnotetext{
${ }^{70}$ DURHAM, Eunice R. Educação superior, pública e privada, p. 215.

${ }^{71}$ CARVALHO, Cristina Helena Almeida de. A política pública para a educação superior no Brasil (1995-2008): ruptura e/ou continuidade?, p. 30.

${ }^{72}$ VALE, Andréa Araujo do. A expansão do segmento privado-mercantil na educação superior brasileira - o caso da Estácio de Sá. In: $35^{\text {a }}$ Reunião Anual da Associação Nacional de Pós-Graduação e Pesquisa em Educação, 2012, Porto de Galinhas. Educação, Cultura, Pesquisa e Projetos de Desenvolvimento: o Brasil do século XXI. Rio de Janeiro: ANPED, 2012, p. 6.

${ }^{73}$ RODRIGUES, Gabriel Mário (Presidente da Associação Brasileira de Mantenedoras de Ensino Superior).
} 
de valores, que ocasionou a introdução de gestores por parte do fundo de investidores que assume o controle da instituição, além da nomeação de professores para cargos de gestão educacional, permitindo a criação de uma cultura interna que não existiria anteriormente, apesar do empreendedorismo de um negócio que começou como uma estrutura familiar. $^{74}$

Às mudanças legislativas educacionais da década de 1990, com a posterior opção de uma série de mantenedoras pela forma comercial, passando a se instituir como entidades com fins lucrativos, soma-se a liberalização e massificação no setor, a fim de criar as condições para o ingresso do capital estrangeiro no setor privado educacional brasileiro. Tem início a difusão de atores e instituições internacionais em todas as partes do Brasil e, a medida em que se ingressa na fase do capital aberto, o setor educacional gradualmente vai sendo desnacionalizado. ${ }^{75} \mathrm{O}$ Entrevistado 09, consultor do setor educacional privado, entende que

"o principal papel desempenhado pela entrada do capital internacional foi a percepção da necessidade premente de profissionalização dos serviços educacionais, em todas as suas esferas. Assim, creio que esse tenha sido o principal papel do capital internacional, a partir do momento em que deixou evidente para os gestores educacionais que não há caminho fora da efetiva capacitação e qualificação de todos os envolvidos no mercado educacional." 76

De outro lado, o Entrevistado 10, também consultor do setor educacional privado, reconhece o papel da entrada do capital estrangeiro, mas como um elemento que colabora com a consolidação do setor da educação superior, na medida em que "esse aporte de recursos financeiros já encontrou um sistema bem forte, controlando $90 \%$ das instituições de ensino superior do país e abrigando cerca de $75 \%$ dos estudantes desse nível." 77 Assim, um número cada vez maior de mantenedores de instituições privadas tem decidido pela articulação com investidores

\footnotetext{
${ }^{74}$ Entrevistado 02 (Diretor de Curso do grupo nacional A). Entrevistador: Lucas da Silva Tasquetto, 26 Fev. 2013.

${ }^{75}$ GOMES, Alfredo M.; ROBERTSON, Susan L.; DALE, Roger. The social condition of higher education: globalisation and (beyond) regionalisation in Latin America, p. 238.

${ }^{76}$ Entrevistado 09 (Consultor do setor privado educacional). Entrevistador: Lucas da Silva Tasquetto, 01 Abr. 2013.

${ }^{77}$ Entrevistado 10 (Consultor do setor privado educacional). Entrevistador: Lucas da Silva Tasquetto, 10 Dez. 2013.
} 
internacionais, tanto para potencializar o lucro por meio do aporte de investimentos externos, quanto, em alguns casos, como estratégia para viabilizar a governança da instituição, com a profissionalização da gestão. ${ }^{78}$ Isso pode ser realizado mediante associação com redes internacionais e a transferência de mantença, mecanismo pelo qual se dão as aquisições, ou pelo canal da participação acionária em sociedades anônimas, no caso de instituições de educação superior que ingressaram na bolsa de valores recentemente, via oferta pública inicial de ações (IPOs).

O setor da educação superior ingressa na bolsa de valores em 2007, por intermédio de três grupos: Anhanguera Educacional S.A., Kroton Educacional S.A. e Estácio Participações S.A. Desde então, houve um forte movimento de consolidação do setor via aquisição de instituições menores. ${ }^{79}$ A SEB em um primeiro momento também seguiu esse caminho, mas posteriormente recuou, estando hoje nas mãos do grupo britânico Pearson PLC. ${ }^{80}$ Antes disso, ainda em 2001, a Apollo Group, um dos maiores grupos educacionais lucrativos do mundo, estabeleceu uma parceria com o grupo Pitágoras (posteriormente absorvido pela Kroton Educacional), forjando a talvez primeira entrada dos fundos de investimentos na área da educação superior privada, ${ }^{81}$ dela retirando-se posteriormente. Mesmo fora desse grupo de empresas com capital aberto, o setor educacional prosseguiu em intenso processo de fusões e aquisições, em boa parte por iniciativa de empresas norte-americanas presentes no Brasil, como a Laureate Brasil, Whitney International e DeVry Brasil. Uma das primeiras aquisições por um grupo estrangeiro foi realizado pela Laureate, em dezembro de 2005, ao adquirir 51\% do capital da universidade Anhembi Morumbi, fundada pelo professor Gabriel Mário Rodrigues. ${ }^{82}$

Em 22 de abril de 2013 foi anunciada a fusão entre Anhanguera e Kroton, com a incorporação de ações da primeira pela última, dando origem a uma

\footnotetext{
${ }^{78}$ SAMPAIO, Helena. O Setor Privado de Ensino Superior no Brasil: Continuidades e Transformações, p. 40.

${ }^{79}$ As empresas de educação na bolsa diante de um ciclo virtuoso. Valor Econômico, 19 Out. 2010. Disponível em: http://www.valor.com.br/arquivo/852691/empresas-de-educacao-na-bolsa-diante-deum-ciclo-virtuoso.

${ }^{80}$ TREVISANI, Paulo. Universidades privadas se multiplican en Brasil. The Wall Street Journal, 26 Jun. $2011 . \quad$ Disponível em: http://online.wsj.com/news/articles/SB10001424052702304447804576410414208690234?tesla=y\&tes la=y. Acesso em 27 Jun. 2011.

${ }^{81}$ ALMEIDA, Wilson Mesquita de. Ampliação do Acesso ao Ensino Superior Privado Lucrativo Brasileiro: um Estudo Sociológico com Bolsistas do Prouni na Cidade de São Paulo, p. 64.

${ }^{82}$ OSCAR, Naiana. Educação que dá dinheiro. O Estado de São Paulo, 11 Jun. 2012. Disponível em: http://economia.estadao.com.br/noticias/geral,educacao-que-da-dinheiro-imp-,884821. Acesso em 11 Jun. 2012.
} 
companhia que alcançará valor de mercado próximo a 12 bilhões de reais. Conjuntamente, são mais de 800 unidades de ensino superior e 810 escolas associadas distribuídas por todos os Estados brasileiros, englobando um universo de aproximadamente um milhão de alunos no segmento de educação superior, educação profissional e outras atividades associadas à educação no Brasil. ${ }^{83}$ Finalmente, em outubro de 2013, os grupos Ser Educacional ${ }^{84}$ e Anima Educação ${ }^{85}$ juntaram-se à Anhanguera, Estácio e Kroton, e abriram o seu capital na bolsa de valores via IPOs. O primeiro captou mais de 619 milhões de reais ${ }^{86}$ e o segundo mais de 468 milhões de reais ${ }^{87}$, que serão direcionados por ambos para aquisição de outras instituições de ensino no Brasil. ${ }^{88}$

No debate sobre a relação entre educação superior, globalização e projetos regionais na América Latina e no Brasil, houve profunda transformação tanto no setor - comercialização, privatização e mercantilização (marketisation) - como no papel do governo nacional brasileiro:

83 KROTON. Comunicado Kroton - Fato Relevante, 22 Abr. 2013. Disponível em: http://ri.kroton.com.br $/ /$ kroton $2010 / \mathrm{web} /$ conteudo pt.asp?tipo $=32853$ \&idioma $=0 \&$ conta $=28$. Acesso em 28 Abr. 2013.

84 "O Grupo Ser Educacional surgiu em 1993, com a fundação do Complexo Educacional Bureau Jurídico, com foco em cursos preparatórios para concursos, na cidade do Recife. Atualmente, a rede é composta de 23 unidades, sendo uma delas um centro universitário, todas localizadas no Nordeste e Norte, regiões do Brasil na qual a empresa acredita apresentar maior potencial de crescimento em razão de possuírem as menores taxas de penetração do ensino superior." (Informações disponíveis em: http://ri.sereducacional.com/sereducacional/web/default_pt.asp?idioma $=0 \&$ conta=28. Acesso em 18 Mai. 2014)

85 “A Anima é uma companhia que atua há 10 anos no setor de ensino superior brasileiro, contando com uma rede de três centros universitários (Una, UniBH e Unimonte) nos estados de Minas Gerais e de São Paulo, e duas Faculdades, nas cidades de Betim e Contagem (Minas Gerais). Adicionalmente, o portfólio inclui também a HSM, instituição de educação corporativa no Brasil. O início do grupo ocorreu em 2003, quando foi feita a aquisição da Minas Gerais Educação Ltda., mantenedora do Centro Universitário UNA ("UNA"), em Belo Horizonte, tradicional instituição de ensino superior da capital mineira." (Informações disponíveis em: http://ri.animaeducacao.com.br/anima/web/default_pt.asp?idioma $=0 \&$ conta=28. Acesso em 18 Mai. 2014).

${ }^{86}$ OLIVON, Beatriz. Ser Educacional estreia na Bovespa com valorização. Exame.com, 29 Out. 2013. Disponível em: http://exame.abril.com.br/mercados/noticias/ser-educacional-estreia-na-bovespa-comvalorizacao.

${ }^{87}$ JULIBONI, Márcio. R\$ 367 mi: o cacife da Anima Educação para ir às compras. Exame.com, 28 Out. 2013. Disponível em: http://exame.abril.com.br/negocios/aquisicoes-fusoes/noticias/r-367-mi-ocacife-da-anima-educacao-para-ir-as-compras.

${ }^{88}$ A primeira aquisição do grupo Anima após a abertura de capital foi a Universidade São Judas Tadeu, uma tradicional instituição paulista, com 25,8 mil alunos. A operação de 320 milhões de reais marca a entrada do grupo na cidade de São Paulo e se insere no discurso dos executivos do grupo de que a estratégia deste "não é pautada pelo crescimento a qualquer custo, para ganho de escala, e sim na qualidade do ensino - o que lhe permite cobrar mensalidades mais caras." (OSCAR, Naiana. Grupo Anima compra Universidade São Judas Tadeu por R\$ 320 milhões. O Estado de São Paulo, 10. Abr. 2014. Disponível em: http://economia.estadao.com.br/noticias/economia-geral,grupo-anima-comprauniversidade-sao-judas-tadeu-por-r-320-milhoes, 181757,0.htm. Acesso em $10 \mathrm{Abr}$. 2014) 
"Se um nível alto de privatização é evidência das forças da globalização, o Brasil está lá; $75 \%$ de todos os estudantes do ensino superior estão no setor privado. Se um nível alto de liberalização é evidência das forças da globalização, o Brasil está lá; todas as áreas da economia têm sido liberalizadas, incluindo as instituições de ensino superior com fins lucrativos. Se um mercado diversificado e moderno é evidência das forças da globalização, o Brasil também está lá; mecanismos de mercado como indicadores de desempenho e rankings ditam o ritmo e as condições para concorrência no ensino superior. Todavia, tudo isso não teria acontecido sem o papel ativo desempenhado pelo governo nacional. Isso reafirma a hipótese geral de que as políticas governamentais domésticas não são atores coadjuvantes na construção da globalização. O papel dos governos nacionais é uma ferramenta poderosa e um canal proeminente para facilitar, se ajustar à, significar ou resistir ao processo de globalização ou projetos de regionalismo, tanto em níveis discursivos-ideológicos quanto em níveis materiais". 89

\subsection{A gestão acadêmica em relação à gestão empresarial em um contexto de comercialização da educação superior}

Para explicar a relação entre gestão empresarial e gestão acadêmica nos estabelecimentos educacionais privados, Gabriel Mário Rodrigues começa por explicar os conceitos de mantenedora e mantida:

"No setor de educação superior, pela legislação, a mantenedora (a empresa) é a entidade jurídica constituída por diversas formas societárias, com finalidade ou sem finalidade de lucro, responsável pelo desenvolvimento econômico da atividade. É a proprietária da atividade educacional. (...)

\footnotetext{
${ }^{89}$ Tradução do inglês: "If a higher level of privatisation is evidence of globalisation forces, Brazil is there; $75 \%$ of all HE students are in the private sector. If a higher level of liberalisation is evidence of globalisation forces, Brazil is there; all areas of the economy have been liberalised, including for-profit HEIs. If a diversified and modern market is evidence of globalisation forces, Brazil is also there; market mechanisms such as performance indicators and rankings set the pace and condition for HE competitiveness. However, all these would not have happened without the active role played by the national government. This reaffirms the general assumption that national government policies are not coadjutant actors in the making of globalisation. The role of national government is a powerful tool and a prominent channel to facilitate, adjust to, signify or resist the globalisation process or regionalism projects, either at discursive-ideological or at material levels." (GOMES, Alfredo M.; ROBERTSON, Susan L.; DALE, Roger. The social condition of higher education: globalisation and (beyond) regionalisation in Latin America, p. 234)
} 
A unidade educacional, a mantida (a faculdade/universidade) tem toda a sua atividade, desde a autorização ao reconhecimento e avaliação, subordinada ao Ministério de Educação. Tem estrutura própria formada pelos diretores, coordenadores, professores e funcionários administrativos. Pela legislação, tem autonomia didática, pedagógica e administrativa. Unicamente tem de aprovar seu plano econômico junto a mantenedora. (...)

Historicamente os mantenedores que foram os criadores das instituições, apesar de terem profissionais atuando tanto na mantenedora como na instituição educacional, na maioria das vezes eram os Presidentes das empresas (Mantenedora) e diretores ou o maior dirigente da Mantida (Faculdade/Universidade) tinham uma influência muito grande no destino da Mantida. Hoje com o tamanho maior das organizações as funções do negócio ficaram com a empresa e a do ensino com a unidade educacional. Dentro da realidade atual, como a busca das metas econômicas é um objetivo a ser alcançado, a gestão empresarial está bastante apoiada na gestão acadêmica, embora a tendência com o tempo seja uma procura maior para a harmonização das duas áreas. $\mathrm{O}$ atual momento mostra o sistema universitário muito igual em suas propostas acadêmicas. Existe aliás uma comoditização dos cursos o que exigirá soluções que beneficiarão quem melhor apostar na qualificação da academia. E consequentemente ela terá maior expressão." 90

De acordo com o entrevistado, se outrora a relação mantenedoramantida era muito próxima, ou seja, com a gestão do negócio colada à gestão acadêmica e concentrada nos criadores das instituições, a consolidação do setor da educação superior e o crescimento dos grupos educacionais ensejaram a separação entre a condução do negócio e a organização do ensino. Para o mesmo, a tendência, no entanto, seria a maior harmonização entre ambas as áreas, dada a necessidade de qualidade na educação como um diferencial na crescente concorrência que se estabelece no setor. No que tange às diferenças entre os maiores grupos educacionais domésticos e os grupos estrangeiros com presença no Brasil,

"Institucionalmente há diferença entre os dois grupos. Os primeiros (Anhanguera, Kroton e Estacio de Sá) são sociedades anônimas brasileiras que abriram o capital na bolsa de valores através de IPOs para conseguir capital para crescer e adquirir outras instituições. Apesar dos investidores serem representados na sua maioria por fundos estrangeiros, a administração dominante está na mão de profissionais brasileiros. O segundo grupo representa empresas educacionais americanas de capital fechado, que

\footnotetext{
${ }^{90}$ RODRIGUES, Gabriel Mário (Presidente da Associação Brasileira de Mantenedoras de Ensino Superior).
} 
adquiriram instituições no Brasil. Para crescer também precisaram ter sócios investidores capitalistas. No primeiro grupo há uma maior pulverização das ações e o poder está entre o relacionamento de um Conselho de Administração forte e o Grupo executivo. No segundo grupo, o poder está concentrado nos maiores acionistas que estão no exterior e comandam as atividades econômicas das instituições compradas. Em relação às diferenças estratégicas, estas organizações estão em fase de aperfeiçoamento da gestão e da consolidação das escolas adquiridas que estão espalhadas pelo pais. O marketing é bastante agressivo bem como todo o esforço de conseguir e reter os alunos matriculados. Estão conscientes que a próxima fase é a da diferenciação dos produtos (cursos) e a que tiverem melhor desempenho deverão ter melhores resultados." ${ }^{\prime 1}$

Embora em seus países de origem os grupos estrangeiros também possuam capital aberto na bolsa de valores, com fundos de investimento (private equity funds) no controle de parte significativa de seu capital, não é o caso de suas operações no Brasil, de forma que agem através da transferência de mantença, atuando como mantenedoras das instituições adquiridas, respondendo aos respectivos diretores executivos e diretores financeiros nacionais e regionais. ${ }^{92}$ De todo o modo, sob a perspectiva de gestão do negócio, tanto os grupos domésticos quanto os grupos estrangeiros sofrem críticas, no sentido de que, nessa fase da educação superior no Brasil, suas instituições passam a ser geridas "como mais próximas de um banco, estabelecimento comercial, do que uma instituição de ensino." ${ }^{93}$ A nova diferenciação institucional no ensino superior e as transformações da demanda frente a um mercado em reestruturação condicionaram a pretensão de soberania administrativa das instituições privadas e acentuaram a sua natureza mercadológica. ${ }^{94}$ No caminho da profissionalização da gestão das instituições privadas com fins lucrativos, invariavelmente surge a subordinação da área acadêmica à estratégia empresarial das mantenedoras. Ao contrário da gestão da educação superior como serviço público, a tendência aqui é o predomínio da lógica da esfera econômica, inclusive com uma

\footnotetext{
${ }^{91}$ RODRIGUES, Gabriel Mário (Presidente da Associação Brasileira de Mantenedoras de Ensino Superior).

${ }_{92}$ Entrevistado 01 (Pró-Reitor da Instituição A adquirida por grupo estrangeiro). Entrevistador: Lucas da Silva Tasquetto, 13 Dez. 2012.

${ }^{93}$ Entrevistado 06 (Professor da Instituição D adquirida por grupo estrangeiro). Entrevistador: Lucas da Silva Tasquetto, 13 Mar. 2013.

${ }^{94}$ SILVA JR, João dos Reis; SGUISSARDI, Valdemar. A educação superior privada no Brasil: novos traços de identidade. In: SGUISSARDI, Valdemar (org.). Educação superior: velhos e novos desafios. São Paulo: Xamã, 2000, p. 162-163.
} 
certa liberdade para a gestão acadêmica na medida em que ela não afete as estratégias financeiras da mantenedora. ${ }^{95}$

Sob a perspectiva da ingerência da gestão empresarial na gestão acadêmica, e da padronização de currículos e materiais, as entrevistas trouxeram uma nova hipótese, de que os grupos estrangeiros investindo no Brasil, ao contrário dos grupos domésticos, teriam um respeito maior à cultura e à organização das instituições adquiridas. Com experiência como professor e gestor de instituições diferentes, controladas respectivamente por um grupo doméstico e um grupo estrangeiro, o Entrevistado 03 aponta:

\begin{abstract}
"São modelos distintos. (...) Eu tenho uma matriz de resultados, você vai ter que me entregar esses resultados, mas como você faz o negócio no seu país é problema seu. (...)

$\mathrm{Na}$ verdade, quando eu olho o pessoal da Estácio, Kroton e Anhanguera. Eles sonham, né, é um sonho de que o Brasil seja esse trampolim para o mundo. Isso é concreto mesmo. (...) Falta uma coisa fundamental em negócios, dentro da minha opinião, que é cultura. Não que os executivos brasileiros sejam péssimos executivos. Pelo contrário, são ótimos executivos, mas falta densidade, cultura internacional, que tem um que de antropologia. Tem um que da capacidade de lidar com culturas diversas. (...)

Então, nós brasileiros, para nós mesmos, nós somos muito mais perversos do que um estrangeiro que chega, que tenham um pouco de cultura internacional, que sabe que tem um marco imenso de antropologia que você tem que lidar." ${ }^{.96}$
\end{abstract}

Assim, quando adquiridas por um grupo nacional, as instituições recém incorporadas ao grupo são padronizadas. ${ }^{97} \mathrm{Em}$ muitos casos, há políticas de demissões e substituição de professores com doutorado.

Por outro lado, no universo dos depoimentos colhidos em instituições adquiridas por grupos estrangeiros, as declarações são no sentido de que, como regra, a mantenedora não se envolve na gestão acadêmica da instituição, desde que as metas de atração de novos alunos venham sendo cumpridas, com maior liberdade para o

\footnotetext{
${ }^{95}$ SILVA JR, João dos Reis; SGUISSARDI, Valdemar. A educação superior privada no Brasil: novos traços de identidade, p. 164-165.

${ }^{96}$ Entrevistado 03 (Professor da Instituição B adquirida por grupo estrangeiro). Entrevistador: Lucas da Silva Tasquetto, 26 Fev. 2013.

${ }_{97}$ Entrevistado 08 (Gestor da Instituição E adquirida por grupo nacional). Entrevistador: Lucas da Silva Tasquetto, 15 Mar. 2013.
} 
gestor na contratação de novos professores - doutores ou não -, entre outras ações. Inclusive no interior de um mesmo grupo, instituições diferentes possuem gestões acadêmicas e modelos de captação de alunos distintos. ${ }^{98}$ Quantos aos professores, estes dizem não terem recebido "nenhum tipo de ingerência a cerca de metodologia, conteúdo de aula"99; descrevem um contexto em que desfrutam de autonomia, sem práticas pedagógicas comuns ${ }^{100}$ e com uma preocupação acadêmica. ${ }^{101}$

De todo o modo, no atual processo de globalização sem raízes, que toma como valor central e objetivo imediato a cultura de servir às demandas do mercado e da busca do lucro, ${ }^{102} \mathrm{o}$ interesse econômico de grupos domésticos e estrangeiros é o mesmo, e todos perseguem novas instituições a serem adquiridas, em um movimento contínuo de consolidação do setor educacional no Brasil.

A princípio, teríamos assim dois vieses distintos em relação à cultura de negócios da instituição adquirida: enquanto um permite maior liberdade e menor grau de padronização, com a preservação das instituições, ainda que inseridas dentro de um contexto empresarial global e hierárquico, o outro traz maior verticalização, inserindo-se de maneira mais aguda em um contexto de oferta de educação em massa, deixando de lado a cultura acadêmica local.

Confrontados com a hipótese de uma abordagem distinta entre os grupos educacionais estrangeiros no Brasil e os grupos domésticos, os consultores educacionais privados entrevistados entendem que suas estratégias seriam, na verdade, semelhantes. Em relação ao mercado, comparativamente, os grupos domésticos inclusive teriam mais pontos positivos. De um lado, pareceriam mais comprometidos com o mercado brasileiro, menos sujeitos aos reflexos das "reacomodações" do mercado internacional; de outro, teriam maior agilidade na tomada de decisões:

"aparentemente, a estratégia pode ser identificada como semelhante, com a busca da ampliação de sua atuação pela mera aquisição de

\footnotetext{
${ }^{98}$ Entrevistado 01 (Pró-Reitor da Instituição A adquirida por grupo estrangeiro).

${ }^{99}$ Entrevistado 06 (Professor da Instituição D adquirida por grupo estrangeiro).

${ }^{100}$ Entrevistado 07 (Professor da Instituição D adquirida por grupo estrangeiro). Entrevistador: Lucas da Silva Tasquetto, 14 Mar. 2013.

${ }^{101}$ Entrevistado 05 (Professor da Instituição D adquirida por grupo estrangeiro). Entrevistador: Lucas da Silva Tasquetto, 01 Mar. 2013.

${ }^{102}$ GOMES, Alfredo M.; ROBERTSON, Susan L.; DALE, Roger. The social condition of higher education: globalisation and (beyond) regionalisation in Latin America, 233.
} 
novas instituições, num processo que muito se assemelha à aquisição de gado, no qual o poder do dono é medido mais pela quantidade de cabeças no pasto do que, propriamente, pela sua produtividade. Evidentemente, os grupos internacionais voltaram sua atenção ao País em decorrência da notória retração do mercado internacional, de modo que a sua atuação no mercado brasileiro pode sofrer reflexos das reacomodações do mercado internacional, inclusive com a busca de novos produtos de investimento que se mostrem mais vantajosos e rentáveis. Os grupos nacionais, por seu turno, parecem mais comprometidos com o mercado nacional, com uma participação menos sujeita a reacomodações." 103

E ainda:

“Não conheço 'por dentro' as instituições controladas por esses grupos. Com base no que venho observando, nos contatos e entrevistas com alguns dos dirigentes dessas instituições e em eventos fechados vejo com mais desenvoltura os grupos brasileiros. Os grupos internacionais, embora tenham a sua condução, no Brasil, nas mãos de experientes profissionais da gestão universitária, dependem das políticas e decisões da matriz. Isso talvez limite a agilidade nas ações. Mas em termos de desempenho não vislumbro diferenças significativas."

\subsubsection{A relação entre o professor e o aluno como cliente/consumidor}

Considerando o setor privado com fins lucrativos como um todo, o que caracteriza a instituição com fins lucrativos de sucesso é o claro foco na educação e no treinamento para o trabalho, aliado à ênfase no estudante como cliente ou consumidor. Enquanto as instituições tradicionais são geralmente descritas mais como centradas na figura do professor do que na figura do aluno, nas instituições com fins lucrativos o estudante é soberano. ${ }^{105}$ No entanto, quando questionados sobre o estudante como aluno ou como cliente/consumidor, os entrevistados relatam uma situação na qual o primeiro corresponde à relação com o professor em sala de aula, e

\footnotetext{
${ }^{103}$ Entrevistado 09 (Consultor do setor privado educacional). Entrevistador: Lucas da Silva Tasquetto, 01 Abr. 2013.

${ }^{104}$ Entrevistado 10 (Consultor do setor privado educacional). Entrevistador: Lucas da Silva Tasquetto, 10 Dez. 2013.

${ }^{105}$ BRENEMAN, David W. Introduction. In: BRENEMAN, David W.; PUSSER, Brian; TURNER, Sarah E. (edit.). Earnings from Learning: The Rise of For-Profit Universities. Albany: State University of New York Press, 2006, p. xi.
} 
o segundo na relação com o gestor educacional, que deve lhe oferecer a melhor experiência possível. ${ }^{106}$

Na relação com a instituição, os alunos "têm que ser bem atendidos, os processos têm que melhorar, o aluno não pode esperar mais de uma semana resultado de requerimento." 107 Em sala de aula, apesar do discurso do aluno como cliente/consumidor, a realidade seria outra:

"Falo pela experiência e pelo próprio discurso. Muda nada, não muda nada. (...) Claro, tem o discurso, mas como esse é um discurso que já tem mais de 10 anos, mais de 15 anos esse discurso, isso já está completamente dissociado da prática objetiva em sala de aula. O aluno é aluno do professor e cliente da organização. São duas coisas distintas. (...)

Então, assim, na verdade esse processo do cliente, esse é um discurso que, em localizações mais ... (sic) onde a força de trabalho docente é mais ou menos organizada, esse discurso, primeiro morre na primeira esquina, que é a própria sala de aula, porque na hora que o professor tem que ser professor ele tem que ser professor, simples assim." 108

\subsubsection{Padronização}

Um dos aspectos mais controversos do modelo educacional atribuído aos grupos privados educacionais com fins lucrativos é a produção centralizada de currículos padronizados para os cursos, diferente do que se dá nas instituições mais tradicionais, em que cada professor cria o seu programa de ensino de acordo com o curso a ser ministrado. Essa medida busca aliar a facilidade para a mobilidade do aluno entres seus diferentes campi, já que os cursos serão exatamente iguais ainda que em cidades distintas, com o ganho em economia de escala, aumentando o poder de barganha do grupo educacional no momento de negociar a compra de livros didáticos junto às editoras. ${ }^{109}$ Diz-se que professores mais experientes poderiam adaptar em

\footnotetext{
${ }^{106}$ Entrevistado 02 (Diretor de Curso do grupo nacional A).

${ }^{107}$ Entrevistado 04 (Coordenador de Curso da Instituição C adquirida por grupo estrangeiro).

${ }^{108}$ Entrevistado 03 (Professor da Instituição B adquirida por grupo estrangeiro).

${ }^{109}$ BRENEMAN, David W. The University of Phoenix: Icon of For-Profit Higher Education. In: BRENEMAN, David W.; PUSSER, Brian; TURNER, Sarah E. (edit.). Earnings from Learning: The Rise of For-Profit Universities. Albany: State University of New York Press, 2006, p. 77-82.
} 
algum grau o programa de determinada disciplina, à condição de empregar o material que lhe foi originalmente destinado. Fica evidente, porém, o alto risco de uniformização das práticas pedagógicas e de declínio da qualidade dos serviços educacionais e da pesquisa acadêmica. ${ }^{110}$

Também em relação à padronização, as entrevistas repetem a hipótese de uma postura distinta entre os grupos domésticos e os grupos estrangeiros no Brasil - ainda que em seus países de origem tendam a reproduzir as medidas de uniformização de currículos e materiais. De um lado, o Entrevistado 02, Diretor de Curso do grupo nacional A, em termos de padronização dos currículos, ressalta a criação de um projeto matriz, a partir das diretrizes curriculares dadas pelo MEC. Não obstante, os professores teriam a liberdade, em sala de aula, de adaptar os programas das disciplinas, além de contarem com um espaço virtual, com material de apoio e "web aulas" disponíveis. ${ }^{111}$ Como apontado pelo Entrevistado 07, também avaliador do MEC, o grupo doméstico em questão apresentaria ainda apostilas padronizadas. ${ }^{112}$

Antes coordenador em um grupo educacional doméstico, o Entrevistado 03 explica como o controle de gastos que conduz à padronização interfere em sala de aula, reagindo à ideia da plena liberdade do professor de contornar o programa das disciplinas e o material comum à toda estrutura do grupo:

"O negócio é ensino, então todas as matrizes determinantes do controle de gastos vão ser na sala de aula, entende? (...) só que é um modelo de padronização que interfere demais na parte dinâmica do negócio que é a própria aula, que é a própria sala de aula. (...)

Hoje, por exemplo, e eu fiz parte do pessoal que fez isso no grupo nacional $A^{113}$, tentei fazer da melhor maneira possível, mas hoje $o$ grupo nacional $A$ tem um modelo de ensino que, quando todos os coordenadores como eu estavam lá saírem, seguramente vai virar uma coisa profundamente padronizada. Porque a gente que fez o negócio, a gente sabe que aquilo é ferramenta só. Uma discussão. Você tem o material didático, mas aquilo não é o curso, aquilo não é a aula, é uma ferramenta. O professor pode, inclusive, se ele achar que tem como fazer melhor, pode não usar aquilo. (...)

"É, mas na medida em que o coordenador tem a visão de que tudo tem que ser padronizado, isso passa a ser tornar o modo como o

\footnotetext{
${ }^{110}$ LARSEN, Kurt; VINCENT-LANCRIN, Stéphan. International Trade in Educational Services: Good or Bad? Higher Education Management and Policy, v. 14, n. 3, 2002, p. 30.

${ }^{111}$ Entrevistado 02 (Diretor de Curso do grupo nacional A).

112 Entrevistado 07 (Professor da Instituição D adquirida por grupo estrangeiro).

${ }^{113}$ Alteração feita pelo autor para preservar a identidade do entrevistado.
} 
professor tem que ser avaliado pelo aluno. Aí, daqui a pouco, a aula vai se resumir a meia dúzia de capítulos que cobre o conteúdo inteiro de uma determinada disciplina." 114

De outro lado, nos grupos educacionais estrangeiros no Brasil e cobertos nesse trabalho, não se vê apostilas e tampouco currículos padronizados, ainda que o sistema de utilizar modelos de outras instituições do grupo para a abertura de novos cursos sofra a crítica de que conduz a uma "pasteurização", já que se impõe e passa a ser implementado rapidamente, sem a construção coletiva pelos professores da instituição que ocorria outrora. ${ }^{115} \mathrm{O}$ Entrevistado 01, Pró-Reitor da Instituição A adquirida por grupo estrangeiro, confirma essa estrutura de padronização, que não se vale de apostilas e currículos uniformes, mas garante uma série de padrões comuns a todas as instituições e também "melhores práticas" (best practices), discutidas anualmente com todos os membros do grupo do mundo, de forma a garantir o aproveitamento das melhores experiências de cada instituição do grupo. ${ }^{116}$

Essas diferenças e as questões do respeito à cultural organizacional da instituição adquirida se repetem nas entrevistas em relação à política de aquisições dos grupos educacionais, voltada tanto para simplesmente aumentar a capilaridade e tamanho do grupo - tendo prioridade a saúde financeira da instituição e o número de alunos - quanto para servir como vitrine e, principalmente, permitir que o modelo de sucesso seja compreendido e utilizado nas outras instituições do grupo. Naturalmente, as políticas de aquisições respondem não só a um padrão acadêmico porventura específico a cada grupo educacional, mas especialmente a questões mais profundas de mercado. $\mathrm{O}$ depoimentos permitem identificar alguns padrões a partir da perspectiva dos atores entrevistados e de suas experiências como profissionais dentro das instituições e eventualmente como avaliadores do MEC.

O maior ou menor grau de padronização de cada grupo ajudaria a determinar, assim, o tipo de estabelecimento procurado e as consequências que a aquisição pode trazer para a adquirida. Ao contrário dos grupos domésticos com capital aberto na bolsa de valores, nos quais a instituição adquirida é incorporada ao grupo e rapidamente padronizada de acordo com as políticas gerenciais do mesmo número de professores, gestores, estrutura física, currículo, material, etc. -, os grupos

\footnotetext{
${ }^{114}$ Entrevistado 03 (Professor da Instituição B adquirida por grupo estrangeiro).

${ }^{115}$ Entrevistado 06 (Professor da Instituição D adquirida por grupo estrangeiro).

${ }^{116}$ Entrevistado 01 (Pró-Reitor da Instituição A adquirida por grupo estrangeiro).
} 
educacionais estrangeiros comparativamente parecem tolerar instituições com vocações mais diversas, com gestões acadêmicas e níveis de qualidade igualmente diferentes. ${ }^{117}$ Não obstante, mesmo no âmbito dos grupos nacionais, são estabelecidas diferenças entre o tipo de instituições adquiridas por Anhanguera e Kroton, de um lado, e pela Estácio, de outro. ${ }^{118}$ Nesse sentido, as duas primeiras se concentrariam na aquisição de instituições destinadas ao ensino de massa e sem maiores ambições de alcançar uma nota superior ao 3 na avaliação do MEC, já suficiente para permitir o funcionamento das mesmas, enquanto a Estácio o faria em menor grau; os grupos estrangeiros se interessariam também por instituições com boa avaliação, crescente vocação de pesquisa e preparadas para competir com confessionais mais tradicionais em alguns polos regionais. ${ }^{119}$

Não se pode descartar, por outro lado, o papel cumprido pelo processo inicial de fusões e aquisições em relação a uma série de estabelecimentos então em

\footnotetext{
${ }^{117}$ Sob outra perspectiva, Garcia apresenta as redes educacionais sob dois diferentes perfis, que não dizem respeito a uma segmentação nacional/internacional, mas sim à manutenção ou não da marca da instituição adquirida e a sua incorporação a um centro centralizado de gestão. Assim, as primeiras operariam instituições de ensino superior de "marcas" regionais, e, de modo geral, adquiririam instituições de boa reputação local, com a ideia de manter a marca, enquanto a gestão acadêmica e financeira convergira para um centro de gestão compartilhado com as demais unidades da rede. Nesse grupo estariam a Kroton, a Laureate, a DeVry e a Anima. De outro lado, estariam as redes educacionais que adquirem a instituição de ensino superior e substituem a marca local pela sua marca de atuação nacional. Aliado à transferência da gestão acadêmica e financeira da adquirida para um centro de gestão compartilhada, se daria também a padronização da estrutura pedagógica e dos materiais didáticos dos cursos oferecidos pela rede. Corresponderiam a essa descrição a Anhanguera e a Estácio (GARCIA, Carolina Policarpo. Efeito rede em fusões no ensino superior. Escola de Economia de São Paulo da Fundação Getúlio Vargas (Dissertação de Mestrado). São Paulo, 2014, p. 13).

${ }^{118}$ De acordo com o Entrevistado 03: "se você for olhar assim, a Anhanguera é mais agressiva na aquisição, em número de alunos, e a Kroton tem sido no último ano, nos últimos dois anos. Mas a Anhanguera comete erros graves (...). A Estácio está em mais de 100 cidades do Brasil, né, com um determinado perfil socioeconômico, e tem adquirido somente dentro dessa estratégia" [...]. (Entrevistado 03 - Professor da Instituição B adquirida por grupo estrangeiro). O Entrevistado 02, Diretor de Curso do grupo nacional A, também marca diferenças entre o processo de aquisições de novas faculdades pela Anhanguera e Kroton, de um lado, e pela Estácio, de outro, no sentido de que a Estácio não compraria alunos, mas sim bases para crescimento, a partir de uma lógica estratégica anterior, que passaria antes pelo setor regulatório e pela própria diretoria de ensino do grupo. No entanto, a ressalva feita ainda pelo Entrevistado 03 é de que a Estácio tem crescido "vegetativamente", chegando num ponto de saturação na maior parte das unidades dela: "A Estácio tem fôlego pra isso, porque a Estácio tem crescido na direção do ensino à distância, e desenhou os seus currículos de tal maneira que foram criadas muitas janelas de presencialidade, entende? Então, permite que você, com uma boa engenharia, inteligência de mercado, você consiga construir no mesmo espaço físico, por isso é que eu estou falando, a estratégia da Estácio é completamente diferente das outras. No mesmo espaço físico, ela vai ter quase que o dobro da quantidade de alunos porque os currículos foram modificados de tal maneira que permite isso." (Entrevistado 03 - Professor da Instituição B adquirida por grupo estrangeiro).

${ }^{119}$ Todos os entrevistados da instituição D adquirida por grupo estrangeiro, por exemplo, reiteraram a política de aquisições deste grupo concentrada em instituições de ensino de renome no Brasil. Instituições que, em muitos locais, se colocariam em um patamar imediatamente inferior somente às universidades públicas e àquelas universidades sem fins lucrativos mais tradicionais, como a Pontifícia Universidade Católica.
} 
estado falimentar e com uma qualidade ainda inferior à estabelecida pelos grupos educacionais voltados ao ensino de massa. Esses casos pontuais representam possivelmente um aspecto positivo da padronização mínima e talvez permitam construir também uma nova hipótese quanto à dualidade das consequências da aquisição de um estabelecimento por um grande grupo educacional: as instituições muito ruins e/ou em graves condições econômicas passariam por uma melhora, ${ }^{120}$ enquanto instituições mais bem posicionadas sofreriam ao se adaptar a um padrão de qualidade mais baixo e a um nível de uniformização que desconsideraria o seu histórico e as suas características particulares.

Assim, em um exemplo que diz respeito à primeira possibilidade, segundo o Entrevistado 03,

“em São Paulo, onde a Estácio é muito ruim, na verdade a Radial. $\mathrm{Na}$ verdade, a Estácio fez um bem fantástico pra Radial, porque a Radial sempre foi muito ruim. Então, assim, ao chegar nesse número de padronização, não sei o que coisa e tal, com algo que não foi adquirido pela gestão atual, era algo do João Uchôa, melhorou muito. "121

Para outros, Anhanguera, Kroton e Estácio possuiriam um modelo de gestão acadêmica adepto da nota mínima $3 .{ }^{122}$ A regulamentação estatal é vista como necessária, dado que com uma gestão enxuta o cumprimento das normas se dá exatamente no limite do mínimo exigido. ${ }^{123}$ Em relação à Anhanguera, são ainda referidos casos de cumprimento temporário de certas regras em algumas de suas instituições, somente no momento da avaliação do MEC, ${ }^{124}$ ou de manobras com as notas específicas - por exemplo, atender parcialmente requisitos de titulação dos professores, ainda que isso conduza a uma nota específica inferior a 3, mas investir em infraestrutura de modo a garantir uma nota 4 , com vista a atingir o conceito médio

\footnotetext{
${ }^{120}$ Nesse sentido, o Entrevistado 08 (Gestor da Instituição E adquirida por grupo nacional), com aproximadamente 20 anos na mesma instituição, classifica a estrutura anterior à venda como praticamente falimentar, sendo que a aquisição por outra instituição seria o último recurso. O novo modelo de gestão é tratado como superior, de modo que a padronização nesses termos seria considerada como positiva.

${ }^{121}$ Entrevistado 03 (Professor da Instituição B adquirida por grupo estrangeiro).

${ }^{122}$ Entrevistado 01 (Pró-Reitor da Instituição A adquirida por grupo estrangeiro); e Entrevistado 03 (Professor da Instituição B adquirida por grupo estrangeiro).

${ }^{123}$ Entrevistado 02 (Diretor de Curso do grupo nacional A).

${ }^{124}$ Entrevistado 04 (Coordenador de Curso da Instituição C adquirida por grupo estrangeiro).
} 
3. ${ }^{125} \mathrm{Um}$ modelo assim, embora possa ser suficiente para instituições em crise, faz com que instituições com conceitos superiores e investimentos em pesquisa e titulação do corpo docente sofram grande impacto com a transição posterior à aquisição. $^{126}$

\subsubsection{Investimentos em pesquisa e pós-graduação stricto sensu}

Em seminário organizado pela ABMES, em 2011, quando suscitada a questão da compatibilidade entre lucro e qualidade na educação superior, Antônio Carbonari Netto, então Presidente da Anhanguera Educacional, relacionou a qualidade educacional nas instituições privadas lucrativas tão somente ao ensino e se refere assim à relação do aluno-trabalhador e a pesquisa:

"impor guela abaixo qualidade do século passado para novo modelo de qualidade pra mim é hipocrisia, naquele sentido que todos querem que sejam imitado, que ele é o bom da bola, e ele não é não. $\mathrm{O}$ número de titulares, quer dizer, titulados numa instituição, o número de doutores é importante? Claro que é importante, mas não é fundamental para a qualidade. O professor tempo integral? Não é fundamental para a qualidade. Tô falando do aluno que vem buscar seu curso em seu curso noturno, o seu diploma para fazer um upgrade na vida. Não estou falando do filho diurno, do jovem que tem condições materiais melhores, que vai ser um pesquisador mais tarde. Não estou falando desse, esse é o pico da curva. É aquele aluno nível A, tempo integral, que alguém paga a escola para ele. Eu tô falando da grande massa de jovens trabalhadores que nós atendemos. Esse aluno, se ele gostasse de pesquisa, ele aprovaria uma assembleia geral na minha instituição e de vocês, e no carnê tava assim 'mensalidade de ensino: tanto', 'mensalidade própesquisa nacional: mais tanto', 'mensalidade para aprimorar professor: mais tanto', ele paga isso? Ele quer pegar um professor já feito. Ele quer pagar, o governo que cuide da pesquisa como política pública e dê dinheiro pra isso. Eu não posso tirar da mensalidade de um jovem trabalhador projetos de pesquisa, qualificação docente,

\footnotetext{
${ }^{125}$ Entrevistado 01 (Pró-Reitor da Instituição A adquirida por grupo estrangeiro).

${ }^{126}$ Por meio da análise dos efeitos de rede, através de uma fusão ou aquisição, sobre uma série de indicadores de qualidade e de desempenho das instituições adquiridas, Garcia emitiu conclusões distintas das aqui apresentadas: "os resultados indicam que a aquisição está associada, em média, a um efeito positivo sobre o Conceito Preliminar de Curso (CPC), sobre o percentual de professores doutores (Doutores) e sobre o percentual de professores com regime de dedicação parcial ou integral (Regime). Em particular, os impactos sobre Doutores e Regime parecem ser importantes fontes do efeito positivo verificado sobre o CPC, que corresponde a uma soma ponderada de diversos indicadores do curso, incluindo essas variáveis." (GARCIA, Carolina Policarpo. Efeito rede em fusões no ensino superior, p. 64)
} 
extensão universitária, caríssima, eu não posso fazer isso. Eu tenho que cobrar dele aquilo que ele está disposto a pagar. Então, lucro e qualidade acadêmica podem coexistir, podem coabitar, e eu acho bastante salutar. (...) Agora, é preciso acabar com a teimosia das autoridades educacionais, de achar que qualidade é aquilo que eles acham que seja, né, que eles são virtuosos, né, então isso tá errado. Qualidade é aquilo que os alunos precisam, que os satisfazem."127

Esta fala reflete a realidade da maioria das instituições de ensino do segmento privado lucrativo, com baixíssimos investimentos em pesquisa e o foco tão somente no ensino, quase em sua totalidade em nível de graduação. Contudo, as entrevistas realizadas trouxeram um cenário significativamente distinto, em especial nas instituições adquiridas por grupos estrangeiros no Brasil, onde, cumpridas as metas e inseridas em uma estratégia de crescimento da instituição, o gestor teria liberdade para criar projetos de pós-graduação stricto sensu e seriam garantidos recursos para tanto. ${ }^{128}$ Nesse sentido, o Entrevistado 04, depois de comentar sobre o investimento na mudança dos contratos de professor horista para professor em tempo parcial ou tempo integral após a venda da instituição, refere os investimentos em pesquisa:

"E aí os professores nesse sentido estão muito felizes, porque a gente tem aberto, tem investido na pós-graduação stricto sensu, que é deficitária, em qualquer lugar, e a gente mesmo assim tem investido, e antes como era coisa familiar era uma coisa meio contida, né. 'Ah, tem que ter três programas', então são três programas. Agora tem que ter quatro programas e dois doutorados. E aí, tem quatro programas já, e a instituição 'pronto, vamos fazer o quinto'. Eu estou fazendo o projeto do quinto programa, que não precisava ter. Antes era assim 'vamos jogar com o regulamento embaixo do braço, tem que ter quatro vamos ter quatro'. Não, agora é quatro, 'vamos fazer o quinto?', 'vamos'. Isso é o que eu estou falando, isso não é ruim porque, assim, a questão do investimento é sentida." $" 129$

Esse movimento, é claro, responde a uma dinâmica do setor educacional em relação às normas do MEC, de forma que os investimentos em pós-

\footnotetext{
${ }^{127}$ CARBONARI NETTO, Antônio. Palestra, 08 Nov. 2011. Seminário ABMES: Lucro e qualidade acadêmica são compatíveis na Educação Superior? Disponível em: http://www.abmes.org.br/abmes/video/detalhe/id/39. Acesso em 25 Fev. 2013.

${ }^{128}$ Entrevistado 01 (Pró-Reitor da Instituição A adquirida por grupo estrangeiro).

${ }^{129}$ Entrevistado 04 (Coordenador de Curso da Instituição C adquirida por grupo estrangeiro).
} 
graduação stricto sensu são necessários para um centro universitário se tornar universidade e, assim, possuir maior liberdade para criar novos cursos, expandir o número de alunos e, por consequência, gerar mais lucros. Ao mesmo tempo,

[...] "na verdade, ter um curso stricto sensu numa universidade retira dela um conjunto de bônus que ela teria que pagar se ela não fosse. Por exemplo, a questão do cartório, que toda universidade é, os diplomas. Se gasta uma fortuna pra registrar diplomas. A medida que você tem uma universidade você não gasta isso."130

Assim, mesmo que o discurso básico dos grandes grupos dedicados ao ensino de massa se concentre na ideia de que a mensalidade não seria para pagar pesquisa, o reconhecimento de que os investimentos em pesquisa podem ser revertidos posteriormente em lucros e/ou contenção de despesas leva, por exemplo, no caso do grupo Estácio, à consolidação de uma diretoria de pesquisa aplicada, que busca desenhar uma carreira com professores que de fato tenham jornada pra fazer pesquisa. ${ }^{131}$ Todavia, o programa de pós-graduação stricto sensu está concentrado na sede do grupo, de modo que os efeitos positivos para a rede como um todo são limitados, em geral ligados às possibilidades de qualificação de professores do grupo selecionado para o ingresso no programa.

De maneira geral, em relação ao argumento de que não haveria espaço para a pesquisa na educação de massa,

"pode-se argumentar que a pesquisa é um luxo com o qual as novas instituições de ES 'de massa' não podem arcar e que em todo caso é supérfluo à tarefa principal de formação da força de trabalho. É verdade que a maior urgência é o aumento do número de matrículas na graduação. Entretanto há fortes argumentos para não se permitir que a pesquisa seja confinada a uns poucos centros de excelência no Brasil, ou que até mesmo seja importada do exterior. Primeiramente, um programa de pesquisa e pós-graduação é benéfico aos alunos, mesmo aqueles não diretamente envolvidos, uma vez que oferece um ambiente de vitalidade intelectual. Em segundo lugar, a concentração da pesquisa nos países ricos significa que os países periféricos como o Brasil tornar-se-ão cada vez mais dependentes, tanto econômica, quanto culturalmente. A falta de pesquisa confina os países periféricos a uma posição de fornecedores de produtos primários e de bens industriais simples,

\footnotetext{
${ }^{130}$ Entrevistado 03 (Professor da Instituição B adquirida por grupo estrangeiro).

${ }^{131}$ Entrevistado 03 (Professor da Instituição B adquirida por grupo estrangeiro).
} 
enquanto o núcleo dos países industrializados mantém poder através das patentes científicas e da hegemonia cultural." ${ }^{\text {"132 }}$

Diferente dos argumentos anteriores, que apresentam elementos pragmáticos sob a perspectiva do gestor educacional para a viabilização de programas de pesquisa mesmo em instituições de ensino superior com fins lucrativos, esta citação remete à experiência do aluno dentro da instituição de ensino e, mais além, ao papel da pesquisa acadêmica consolidada dentro de um eventual projeto de desenvolvimento do país.

\subsection{O outro lado da profissionalização: precarização da docência}

Aparentemente, as diferentes visões estão relacionadas àquilo que os atores reputam como fundamental, ligadas à sua rotina de trabalho ou mesmo a concepções particulares sobre educação e sociedade. Assim, gestores tendem a valorizar a sua própria função dentro da estrutura como algo maior do que faziam ou do que se fazia anteriormente, como se passassem de um regime mais amador para algo mais perto do que chamam de profissional. Os professores, por sua vez, ainda que reconheçam mudanças positivas sobretudo na questão de estrutura física, reiteradamente apontam a perda da relevância do professor como um profissional diferenciado, responsável por algo maior que é a educação:

[...] “A privatização não é simplesmente uma mudança técnica na gestão da prestação de serviços educacionais - ela envolve mudanças no significado e na experiência da educação, o que significa ser um professor e um aprendiz, mas é parte também de um deslocamento social mais amplo." 133

\footnotetext{
${ }^{132}$ McDOWAN, Tristan. O crescimento da educação superior privada no Brasil: implicações para as questões de equidade, qualidade e benefício público, Archivos Analíticos de Políticas Educativas, v.13, n.27, Abr. 2005, p. 15.

${ }^{133}$ Tradução direta pelo autor do inglês: [...] "privatization is not simply a technical change in the management of the delivery of educational services - it involves changes in the meaning and experience of education, what it means to be a teacher and a learner, but is also part of a broader social dislocation." (BALL, Stephen J. Education plc: Understanding private sector participation in public sector education. Abingdon: Routledge, 2007, p. 186)
} 
Essa passagem de um "período romântico" ${ }^{134}$, como colocado nas entrevistas, para uma etapa mais pragmática e despersonalizada enseja duas leituras: a crítica e a preocupação com o futuro das suas instituições; e, de outro lado, uma percepção de que esse seria um passo inevitável, fruto do contexto de comercialização e tecnicização da sociedade como um todo. ${ }^{135}$

Sobre as consequências da mercantilização do ensino superior para os docentes, a literatura apresenta como uma tendência do modelo de gestão a subordinação de tudo ao lucro, "estabelecendo precários planos de carreira, baixa remuneração salarial e pouquíssimo estímulo e investimento nos laços entre ensino, pesquisa e extensão." ${ }^{136}$ Ademais, o Entrevistado 09 entende que este processo parece não ter trazido reflexos positivos para a qualidade do ensino, no sentido de que a instituição tem "vivenciado dispensa de docentes com titulação maior, com uma padronização de práticas pedagógicas, com a indesejável colocação das complexidades decorrentes da diversidade regional em segundo plano."137 Somente no período correspondente ao final do ano de 2011, a Anhanguera Educacional demitiu cerca de 1.500 professores, segundo a Federação dos Professores do Estado de São Paulo (Fepesp), volume que representava naquele momento aproximadamente $34 \%$ do corpo docente das instituições da Anhanguera. ${ }^{138}$ Em 2012, o mesmo grupo demitiu $20 \%$ do seu corpo docente no Estado do Rio Grande do Sul. ${ }^{139}$

Em sentido contrário, o Entrevistado 02 nega veementemente a hipótese da precarização da mão-de-obra em suas instituições. Por um lado, ele afirma que a gestão profissionalizada e a cobrança do ponto aumentaram a assiduidade e pontualidade dos professores, grande queixa dos alunos na fase anterior, ressaltando que no contexto específico de um grupo voltado ao ensino de massa a frequência dos professores é um dos elementos mais importantes para o alunado. Por outro lado, o

\footnotetext{
${ }^{134}$ Entrevistado 04 (Coordenador de Curso da Instituição C adquirida por grupo estrangeiro).

${ }^{135}$ Entrevistado 07 (Professor da Instituição D adquirida por grupo estrangeiro).

${ }^{136}$ AVILA, Sueli de Fatima Ourique de. Mercantilização do Ensino Superior: as consequências das mudanças produtivas para os docentes de ensino superior. Tese (Doutorado em Políticas Públicas e Formação Humana). Universidade do Estado do Rio de Janeiro, 2010, p. 14.

${ }^{137}$ Entrevistado 09 (Consultor do setor privado educacional).

${ }^{138}$ KOIKE, Beth. Anhanguera demite 1,5 mil professores, Segundo Fepesp. Valor Econômico, 06 Fev. 2012. Disponível em: http://www.valor.com.br/empresas/2519622/anhanguera-demite-15-milprofessores-segundo-fepesp. Acesso em 12 Out. 2012.

${ }^{139}$ PIMENTEL, Gabriela. Audiência pública debate demissões no Grupo Educacional Anhanguera. TV Assembleia - Assembleia Legislativa do Estado do Rio Grande do Sul, 24 Abr. 2012. Disponível em: http://www2.al.rs.gov.br/mikibreier/Imprensa/TVAssembleia/tabid/4904/IdOrigem/1/Id_Cadastro_Vid eo/5157/Default.aspx. Acesso em 12 Out. 2012.
} 
processo proporcionou aos professores um plano de carreira que não existia anteriormente à oferta pública de ações, com a figura do docente profissional. ${ }^{140}$

No entanto, mesmo quando se trata de contratos de 20 ou 40 horas, a tendência é manter cada vez mais o professor em sala de aula, diminuindo as possibilidades de remuneração para atividades extraclasse, em uma crítica que se estende dos grupos educacionais domésticos ${ }^{141}$ aos estrangeiros ${ }^{142}$. Conforme o depoimento do Entrevistado 06:

\begin{abstract}
"sim, aonde é que isso bate nos professores? Padrão salarial, redução de carga horária extra classe, porque eles reconhecem e remuneram o professor que está dentro de sala de aula. Qualquer outra atividade extraclasse, pra eles receberam algum tipo de remuneração é muito difícil. Aí, o que acaba ocorrendo? Muitas vezes o professor é demandado em atividades fora de sala de aula ou sem remuneração ou com uma remuneração que não condiz com a tua carga horária. Então, por exemplo, eles podem te dar lá um conjunto de atribuições e te dão duas horas, quatro horas, só que tu tens que fazer quatrocentos negócios, tu tens que te virar em quinhentos." 143
\end{abstract}

Aliado às questões de carga horária e remuneração por pesquisa e extensão, encontra-se o distanciamento crescente do envolvimento do professor do processo de desenvolvimento da instituição e do curso onde leciona. Nesse contexto, “as decisões são tomadas em outro tempo, em outra velocidade, muito mais rápido. É, até onde se percebe, sem grande envolvimento principalmente do corpo docente. Mais da parte administrativa, da parte de gestão mesmo." ${ }^{144}$ Como consequência, o professor deixa de participar ativamente na construção de projetos políticopedagógicos e na delimitação do perfil do curso.

Nestes termos, o impacto gerencial afeta sobremaneira o "espírito de ser professor" ${ }^{\prime 145}$, em uma dinâmica relacionada à instabilidade dentro de uma mesma instituição:

\footnotetext{
${ }^{140}$ Entrevistado 02 (Diretor de Curso do grupo nacional A).

${ }^{141}$ Entrevistado 04 (Coordenador de Curso da Instituição C adquirida por grupo estrangeiro).

${ }^{142}$ Entrevistado 05 (Professor da Instituição D adquirida por grupo estrangeiro).

${ }^{143}$ Entrevistado 06 (Professor da Instituição D adquirida por grupo estrangeiro).

${ }^{144}$ Entrevistado 06 (Professor da Instituição D adquirida por grupo estrangeiro).

${ }^{145}$ Entrevistado 03 (Professor da Instituição B adquirida por grupo estrangeiro).
} 
[...] "primeiro que tu verificava, que os professores normalmente tinham uma trajetória mais longa nas instituições. As mudanças ocorriam, mas elas de forma mais lenta. Algumas decisões elas tinham a presença dos professores. Tu via o envolvimento maior dos professores. Isso aí é nítido. (...)

O professor era tratado de uma forma mais personalizada, né, havia um reconhecimento maior. Hoje, o que significa, as vezes, quando tu vê assim alguns professores que aparecem e daqui a pouco desaparecem, tu não fica sabendo direito. O professor nem chegou a pegar vínculo, e quando tu viu o camarada já sumiu.(...)

O professor ele perde a identidade. Esse crescimento, tudo isso aí, o professor perde a identidade. Tu acaba sendo mais um dentro da estrutura." "146

\subsection{Os grandes grupos educacionais e o ensino de massa}

Como trabalhado no ponto que diz respeito à expansão do setor privado educacional, é importante indicar que o segmento privado em si é heterogêneo. Na América Latina, o setor privado teria três diferentes níveis: a elite secular, o segmento confessional e o nível responsável pela "absorção da demanda", desenvolvido por meio do rápido crescimento das instituições educacionais com fins lucrativos ${ }^{147} \cdot{ }^{148}$ Enquanto existiriam instituições privadas de excelente qualidade nas duas primeiras categorias, o mesmo não poderia ser dito do modelo de "ensino de massa" trazido pelo último, justamente o mais numeroso dentre esses. Assim, a segmentação nacional teria dois grandes níveis, um dualismo entre elite e massa criado por uma dinâmica de escassez e exclusão, tendo na base da pirâmide o ensino superior de massa, prestado pelo "mercado" e, entre outros elementos, marcado pelo expansionismo e pela má reputação. ${ }^{149}$

\footnotetext{
${ }^{146}$ Entrevistado 06 (Professor da Instituição D adquirida por grupo estrangeiro).

${ }^{147}$ GARCÍA-GUADILLA, Carmen. General Agreement on Trade in Services (GATS), and Higher Education in Latin America: Some ideas to contribute to the discussion. Paper prepared for the Convention of Universities Members of Columbus, Paris, Jul. 2002, p. 15. Disponível em: http://www.carmengarciaguadilla.com/articulos/GATSandHEinLA.pdf.

${ }_{148}$ Daniel Levy refere-se ao crescimento da educação privada lucrativa como uma "terceira onda". (Unanticipated Development: Perspectives on Private Higher Education's Emerging Roles, PROPHE Working Paper Series, n.1, Abr. 2002, p. 7. Disponível em: http://www.albany.edu/dept/eaps/prophe/publication/paper/PROPHEWP01 files/PROPHEWP01.pdf) ${ }^{149}$ MARGINSON, Simon. Dynamics of national and global competition in higher education. Higher Education, v. 52, p. 1-39, 2006.
} 
As instituições de ensino de massa, com mensalidades mais baixas e um grande número de alunos, teriam como meta "prover qualificação para o mercado de trabalho e atender às expectativas de ascensão profissional e social de seus alunos" ${ }^{\prime 150}$, sem maiores expectativas de formar o estrato mais alto da sociedade. $\mathrm{Na}$ "divisão funcional" entre o setor público e o setor privado de "elite", os fins da educação superior centrados na produção acadêmica e na cultura crítica apareceriam em contradição com os objetivos primordiais de natureza empresarial, que exigem de maneira imprescindível o lucro. ${ }^{151}$ Assim, o foco imediato do setor privado com fins lucrativos foi direcionado para a ampliação desordenada de vagas em áreas que ofereciam um retorno financeiro superior, em razão da estrutura enxuta que demandam, como os cursos de administração, contabilidade, direito e processamento de dados, restringindo-se ao ensino de graduação, preferencialmente no período da noite. ${ }^{152} \mathrm{Na}$ sequência, essas instituições ampliaram a diversidade de cursos, ajustando seu portfólio à demanda, na medida em que foram pioneiras na criação de cursos que não existiam nas instituições públicas, ao lado da aposta na chamada graduação tecnológica, com cursos de menor duração, mas que também oferecem diploma de nível superior. ${ }^{153}$

Desde a década de 1990 o Brasil tem buscado o desenvolvimento de um sistema de educação superior de massa, já que a meta do Plano Nacional de Educação, de 2001, é de aumentar a oferta de ensino superior a pelo menos $30 \%$ dos jovens entre 18 e $24 \operatorname{anos}^{154}$. O índice médio de matrículas nessa faixa de idade no ensino superior estava em $8.6 \%$ em 1980; mudou para 9.3\% em 1995; subiu para $15.1 \%$ em 2002, chegando a $21.8 \%$ em 2008. ${ }^{155}$ Dados do Censo da Educação Superior apontam o crescimento constante das instituições privadas de educação

\footnotetext{
${ }^{150}$ SÉCCA, Rodrigo Ximenes; LEAL, Rodrigo Mendes. Análise do setor de ensino superior privado no Brasil. BNDES Setorial, n. 30, Set. 2009, p. 125.

${ }^{151}$ SILVA JR, João dos Reis; SGUISSARDI, Valdemar. A educação superior privada no Brasil: novos traços de identidade, p. 166.

${ }^{152}$ SILVA JR, João dos Reis; SGUISSARDI, Valdemar. A educação superior privada no Brasil: novos traços de identidade, p. 167.

${ }^{153}$ SÉCCA, Rodrigo Ximenes; LEAL, Rodrigo Mendes. Análise do setor de ensino superior privado no Brasil, p. 125.

${ }^{154}$ GOMES, Alfredo M.; ROBERTSON, Susan L.; DALE, Roger. The social condition of higher education: globalisation and (beyond) regionalisation in Latin America, p. 235.

${ }^{155}$ GOMES, Alfredo M.; ROBERTSON, Susan L.; DALE, Roger. The social condition of higher education: globalisation and (beyond) regionalisation in Latin America, p. 236.
} 
superior com fins lucrativos, com 3 milhões de matrículas presenciais no setor lucrativo em 2009, representando 77\% do segmento privado. ${ }^{156} 157$

O aumento do número de matrículas explica-se tanto por medidas governamentais para o acesso de indivíduos ao setor privado e a expansão de vagas no setor público, quanto por mudanças recentes no mercado de trabalho:

\begin{abstract}
"a partir de 2004, ganham força iniciativas governamentais voltadas tanto para subsidiar o ingresso de indivíduos de baixa renda no setor privado de ensino (caso do PROUNI) quanto para a expansão de vagas no setor público; assim como politicas especificas de inclusão no ensino superior, como o Reuni e os programas de ação afirmativa. Dado que a maior parte das vagas de ensino superior se encontra em instituições privadas e que os programas de subsídios públicos recobrem apenas uma fração destas, é bastante razoável assumir que o forte aquecimento do mercado de trabalho, com aumento mais que proporcional dos estratos salariais mais baixos, colaborou de forma significativa para a rápida expansão do ensino superior na última década." 158
\end{abstract}

Como um fenômeno global, o processo de massificação também caminhou no Brasil lado a lado com a privatização da prestação da educação superior. Enquanto a massificação trouxe mais estudantes para o sistema, independente do seu impacto sobre os padrões e valores acadêmicos, a privatização foi o meio principal através do qual a mesma foi obtida ${ }^{159}$. A privatização da educação superior, por sua vez, implicou na expansão do setor privado via conversão da educação em mercadoria, e na consequente diminuição da participação relativa do setor público na prestação geral de educação superior, com a retomada de um viés de crescimento das

\footnotetext{
${ }^{156}$ CARVALHO, Cristina Helena Almeida de. Palestra, 10 Out. 2013. Comissão de Educação da Câmara dos Deputados. A Fusão entre as Empresas Kroton Educacional do Grupo Pitágoras, e Anhanguera Educacional, e seu impacto na qualidade do Ensino Brasileiro. Disponível em: http://www2.camara.leg.br/atividade-legislativa/comissoes/comissoespermanentes/cec/reunioes/videoArquivo? codSessao $=46059 \&$ codReuniao $=33860$.

${ }^{157}$ Antes marcado pela fragmentação, cada vez mais o setor privado encontra-se concentrado em grandes grupos educacionais com fins lucrativos. Segundo, Ryon Braga, consultor do setor educacional, o movimento de consolidação na educação privada ainda tem muito espaço para crescer. Já em 2011, os 12 maiores consolidadores do setor possuíam 30\% do mercado, mas podendo chegar a $50 \%$ considerando a disposição dos mesmos e recursos financeiros suficientes para uma série de novas aquisições - naquele momento, Anhanguera, Estácio e Kroton mantinham, juntas, mais de R \$ 1 bilhão para investir em aquisições (BRAGA, Ryon. Negócios no setor de educação privada, 24 Jan. 2011. Disponível em: http://www.hoper.com.br/artigo-hoper.php?id=43. Acesso em 31 Jan. 2013.)

${ }^{158}$ COMIN, Alvaro A.; BARBOSA, Rogério Jerônimo. Trabalhar para estudar: sobre a pertinência da noção de transição escola-trabalho no Brasil, Novos Estudos, n.91, Nov. 2011, p. 76-77.

${ }^{159}$ GOMES, Alfredo M.; ROBERTSON, Susan L.; DALE, Roger. The social condition of higher education: globalisation and (beyond) regionalisation in Latin America, p. 236.
} 
vagas no sistema público somente a partir do Governo Lula. ${ }^{160}$ Consoante a literatura, os objetivos de expansão do ensino superior assumiram formas de políticas de privatização, massificação e mercantilização, que culminaram na construção de um moderno "mercado" de educação superior no Brasil, de modo que caberia questionar se a transição para o sistema de massa se relaciona com a democratização da matrícula, de forma a romper a lógica que manteve boa parte dos jovens fora da universidade até então. ${ }^{161}$

No Brasil, o discurso de representantes do segmento privado lucrativo é articulado em oposição ao setor público, na maior parte das vezes sob o argumento de que as universidades públicas somente serviriam à elite do país e, assim, deveriam inclusive cobrar mensalidades. ${ }^{162} \mathrm{Na}$ construção dessa lógica, por exemplo, o Entrevistado 02 considera os grandes grupos privados como os principais responsáveis pela democratização do acesso ao ensino superior que, ao longo do tempo, fariam a transformação do país através da educação. ${ }^{163}$ Essas declarações se

\footnotetext{
${ }^{160}$ Por outro lado, com referência ao crescimento do número de matrículas no ensino superior no ensino superior como um todo de 4,2 milhões para 6,7 milhões, no período entre 2004 e 2011, houve ampliação e democratização do acesso à educação superior no Brasil. Sob a perspectiva das vagas abertas no sistema público de educação superior, teriam sido fundamentais a política de reestruturação das universidades federais, com o aumento no número de vagas, a valorização dos Institutos Federais de Educação, Ciência e Tecnologia (IFs), e a criação da Universidade Aberta do Brasil, um programa público de educação superior à distância direcionado às licenciaturas. Nesse cenário, as autoras destaquem três instrumentos de destaque: o Prouni, o Enem e o SISU (BUCCI, Maria Paula Dallari; MELLO, Paula Branco de. Democratização e acesso à educação superior - Parte I, Cadernos Flacso, N7, 2013, p. 1).

161 GOMES, Alfredo Macedo; MORAES, Karine Numes de. Educação superior no Brasil contemporâneo: transição para um sistema de massa, Educação \& Sociedade, v.33, n.118, 2012, p. 186.

${ }^{162} \mathrm{O}$ então presidente do grupo Estácio, Eduardo Alcalay, refere-se ao aluno de suas instituições, bem como de outros grupos voltados ao ensino de massa, como o responsável por avaliar a qualidade de seus estabelecimentos. Para tanto, a definição do que seria o aluno dos grandes grupos educacionais privados é construída comparativamente ao que o dirigente entende ser o aluno de uma instituição pública ou de outro segmento do setor privado educacional: "então, senhores, esse aluno é o maior fiscal de todos, porque esse aluno [...], diferentemente do aluno classe A, que está lá na federal ou na estadual, ou até na faculdade privada topo de linha, aquele aluno classe A que chega de carro importado no estacionamento e que tem a sua mensalidade de 2500 reais paga pelo seu pai, que é um empresário bem sucedido, um médico, e que com todo o direito e legitimidade vai lá e paga as melhores escolas e as melhores faculdades pros seus filhos, o nosso aluno é guerreiro, o nosso aluno é esforçado, o nosso aluno sai do expediente às seis, sete horas da noite, pega um ônibus e vai estudar à noite na faculdade. Então, ele é muito exigente, muito mais exigente do que aquele aluno que está lá estudando durante o dia e quando o professor falta ele fala pô que beleza, eu vou pra praia ou vou pro parque ou o nosso aluno é, alguns deles eu tenho certeza que, alguns dos alunos que fizeram essa aí, essa grande problemática na reitoria da USP, tavam mais pela baderna e menos pela ideologia e menos pelos direitos humanos. O nosso aluno é guerreiro e este nosso aluno que paga pela sua mensalidade, ele demanda e ele quer qualidade." (ALCALAY, Eduardo. Palestra, 08 Nov. 2011. Seminário ABMES: Lucro e qualidade acadêmica são compatíveis na Educação Superior? Disponível em: http://www.abmes.org.br/abmes/video/detalhe/id/42. Acesso em 24 Fev. 2013)

${ }^{163}$ Entrevistado 02 (Diretor de Curso do grupo nacional A).
} 
inserem em um contexto de expansão do sistema por meio das vagas oferecidas principalmente pelas instituições de ensino de massa, voltadas sobretudo para as classes C e D, gerando muitos lucros, mas com um modelo educacional centrado quase que unicamente no ensino em sala de aula, cada vez mais dissociado daquele oferecido pelas universidades tradicionais. Com isso tem-se uma tensão entre o papel do Estado como regulador e as demandas desse setor por um sistema de avaliação menos rígido, com base no argumento de que a concorrência garantiria por si mesma a busca da qualidade pelas instituições.

$\mathrm{Na}$ perspectiva do já citado Gabriel Mário Rodrigues, os grandes grupos educacionais operam em uma economia de escala, buscando com anuidades baixas atender padrões de qualidade relativos à avaliação mínima exigida pelo MEC e àqueles que garantam a aceitação dos cursos pelos alunos:

\begin{abstract}
"os grandes grupos atendem principalmente os alunos de menor poder aquisitivo onde a anuidade media não chega a cinco mil reais. Dentro da economia de escala procuram se estruturar da melhor forma na área acadêmica para oferecer os melhores cursos e bons professores. Duas condicionantes obrigam a fazer isto, a concorrência entre eles pelo aperfeiçoamento dos métodos pedagógicos para terem os cursos cada vez mais aceitos pelos alunos e a avaliação de qualidade de cursos pelo MEC, onde entre 1 e 5,a nota 3 é condicionante de um curso poder continuar a ser oferecido sem restrições. Consequentemente a preocupação com a qualidade do ensino esta sempre presente, tanto para melhorar as práticas acadêmicas no sentido de uma maior aceitação dos cursos nas comunidades e tanto para ter nota 3 que é o critério mínimo para um curso ter padrão aceitável de qualidade conforme MEC."164
\end{abstract}

Se, de um lado, os gestores e representantes do setor privado lucrativo tratam esse modelo de ensino de massa como o único possível para seus alunos, tendo em vista o baixo valor das mensalidades e a localização estratégica de suas unidades, de outro, por parte dos professores, existe o reconhecimento deste modelo como "produto" criado e desenvolvido pelas instituições dentro de um "círculo vicioso":

[...] "o perfil do nosso aluno, na esmagadora maioria, é o trabalhador-estudante. O nosso aluno é um trabalhador, né, que à

\footnotetext{
${ }^{164}$ RODRIGUES, Gabriel Mário (Presidente da Associação Brasileira de Mantenedoras de Ensino Superior).
} 
noite, ele está no terceiro turno de trabalho, ele vai para a sala de aula. Aí, o que que ocorre? Qualquer coisa que tu exigir desse aluno extraclasse, que esteja fora do horário dele de sala de aula, tu corre o sério risco de ter uma atividade que não vai render. E isso eu vejo como uma espécie de um círculo vicioso que se cria, porque a instituição ela acaba se voltando pra atender esse tipo de público. A instituição sabe que tem público, que tem clientes, vamos dizer assim, dispostos a comprar esse produto. Então, a instituição acaba se moldando, fazendo um molde pra atender esse pessoal. Então, tu fica com um aluno em sala de aula que só se preocupa com aquele período aí de sala de aula." $" 165$

Nas entrevistas, muitos dos professores referem-se aos "trabalhadoresestudantes" e aos desafios que trazem à rotina de sala de aula - cansaço, pouca leitura dos textos propostos, atenção à universidade dada somente ao momento de sala de aula. Também dão conta do impacto gerado por esse perfil no próprio desenho dos programas das instituições de ensino privado que, em busca de novos alunos, acabam esposando cada vez mais um modelo de ensino com menor cobrança, poucas leituras extras, material padronizado, ausência de pesquisa e extensão, entre outras diferenças que o distanciam das universidades tradicionais.

Quanto aos trabalhadores que chegam tardiamente ao ensino superior, articulando dados do Instituto Nacional de Pesquisas Educacionais Anísio Teixeira (INEP), de 2008 - de que aproximadamente $75 \%$ das matrículas em nível superior foram feitas em instituições privadas, e de que, no mesmo ano, 62,6\% dos graduados frequentavam cursos noturnos -, com dados do PNAD - de que no conjunto de indivíduos frequentando o ensino superior, o crescimento das vagas atingiu com mais força a população ocupada, mais especificamente aquela que trabalha mais de 40 horas por semana -, surge a hipótese de que “a inserção profissional já alcançada pelos indivíduos e a busca por se manter e progredir no mercado de trabalho [é] o que explica esse movimento de volta a escola."

Para os indivíduos, o diploma de ensino superior significa chances de mobilidade social, ascendendo a carreiras profissionais que ofereçam maior satisfação pessoal, status social e salários. No Brasil, a formação no nível de educação superior continua a representar grandes retornos salariais. Ainda que após os anos 2003 e 2004 a diferença percentual entre a renda média decorrente da posse de um diploma de

\footnotetext{
165 Entrevistado 06 (Professor da Instituição D adquirida por grupo estrangeiro).

${ }^{166}$ COMIN, Alvaro A.; BARBOSA, Rogério Jerônimo. Trabalhar para estudar: sobre a pertinência da noção de transição escola-trabalho no Brasil, p. 78-79.
} 
ensino superior em relação àquela decorrente do ensino médio venha caindo, até então significava uma elevação média de $90 \%$ na renda do graduado. ${ }^{167}$

Não obstante, em trabalho envolvendo bolsistas do Prouni, Wilson Almeida, referindo-se ao subgrupo de bolsistas em instituições privadas lucrativas, grande parte de licenciandos e tecnólogos e outra parte relativa de bacharelandos de administração, sustenta a hipótese de que estes "possuem menos condições efetivas de realizar uma mobilidade social sustentável, dada a baixa qualidade socialmente percebida dos cursos e universidades que frequentam." ${ }^{168}$ Mesmo que reconheça a importância que ainda faz ter cursado o ensino superior, o autor aponta que para esses bolsistas o diploma terá somente um valor instrumental como título escolar, com menos peso efetivo. ${ }^{169}$ Talvez esse ponto refira-se ao fato de que, nesse modelo educacional, os alunos que obtêm suas titulações cada vez menos encontram funções profissionais que correspondam aos seus diplomas. De todo o modo, o volume de titulados encontra efeitos positivos a longo prazo de acordo com o Entrevistado 03:

\begin{abstract}
"é, mas aí não é uma coisa brasileira, é uma coisa da ordem capitalista, na verdade. É, mas tem um efeito positivo a longo prazo, que é elevar o nível de qualificação da mão-de-obra em geral. Isso é bom pra sociedade como um todo. Ganhos imediatos com relação a sua própria formação é algo que ninguém pode ter esperança. $\mathrm{O}$ discurso em si que é ruim. Não pode ter esperança de que vá mudar a sua vida completamente porque fez faculdade, e eu falo isso em sala de aula, inclusive. O que faz a diferença é o seguinte, o mundo exige cada vez mais um degrau cada vez mais alto pra você botar a mão na porta do mercado de trabalho."170
\end{abstract}

Nesse sentido, Alvaro Comin e Rogério Barbosa asseveram que não é automática a correspondência entre qualificações específicas e ocupações, o que demandaria tempo e estaria dependente também da qualidade do desenvolvimento econômico: "por mais que as dinâmicas do mercado de trabalho e do sistema educacional estejam entrelaçadas de muitas maneiras, o curso de cada uma delas

\footnotetext{
${ }^{167}$ COMIN, Alvaro A.; BARBOSA, Rogério Jerônimo. Trabalhar para estudar: sobre a pertinência da noção de transição escola-trabalho no Brasil, p. 75-88-91.

${ }_{168}$ ALMEIDA, Wilson Mesquita de. Ampliação do Acesso ao Ensino Superior Privado Lucrativo Brasileiro: um Estudo Sociológico com Bolsistas do Prouni na Cidade de São Paulo, p. 207.

${ }^{169}$ ALMEIDA, Wilson Mesquita de. Ampliação do Acesso ao Ensino Superior Privado Lucrativo Brasileiro: um Estudo Sociológico com Bolsistas do Prouni na Cidade de São Paulo, p. 207.

${ }^{170}$ Entrevistado 03 (Professor da Instituição B adquirida por grupo estrangeiro).
} 
obedece a diferentes logicas e temporalidades." ${ }^{171}$ Para os autores, o padrão representado pela figura do "trabalhador-estudante" não seria um novidade em si no Brasil, considerando o histórico ingresso em idade precoce de sujeitos mais pobres no mercado de trabalho. O que o quadro atual traria de novo seria a corrente expansão do ensino superior como um processo viabilizado por esse perfil de estudante. Desse modo, embora com uma educação de baixa qualidade e a criação insuficiente de vagas para que trabalhem em postos adequados as suas novas qualificações específicas, "dispor de uma força de trabalho mais qualificada confere ao pais maior escopo para "escolher" seus rumos de desenvolvimento e, a esse respeito, mais educação é sempre melhor do que menos educação."172

Com efeito, ainda que esses grupos educacionais tenham como objetivo imediato o lucro e venham crescendo cada vez mais, potencialmente em detrimento da qualidade da educação prestada, é preciso considerar o fato de que a expansão por meio desse modelo educacional levou aos bancos das instituições de ensino superior alunos que antes não as acessavam. Assim, não parece suficiente somente fazer a crítica ao modelo de expansão. ${ }^{173}$ É preciso considerar a mobilidade social que o diploma superior ainda confere, ampliar o debate sobre o modelo de desenvolvimento que o país deseja e desenvolver os canais de avaliação e garantia da qualidade da educação prestada pelos grupos. ${ }^{174}$

A literatura que reconhece o papel do setor privado na expansão do número de vagas no ensino superior, de outro lado, questiona a contribuição do crescimento do setor para a equidade no sistema educacional, tendo em vista a qualidade dos cursos e a reputação dos diplomas obtidos:

\footnotetext{
${ }^{171}$ COMIN, Alvaro A.; BARBOSA, Rogério Jerônimo. Trabalhar para estudar: sobre a pertinência da noção de transição escola-trabalho no Brasil, p. 76.

${ }^{172}$ COMIN, Alvaro A.; BARBOSA, Rogério Jerônimo. Trabalhar para estudar: sobre a pertinência da noção de transição escola-trabalho no Brasil, p. 95.

173 "Seria ilusório acreditar que essa ampliação em massa venha a se fazer exclusivamente pela oferta de vagas públicas. Como reconhece o Plano Nacional de Educação, projeta-se a permanência do setor privado como importante provedor de educação de terceiro grau. O desafio é obter essa ampliação garantindo qualidade da educação." (BUCCI, Maria Paula Dallari. O Art. 209 da Constituição 20 anos Depois. Estratégias do Poder Executivo para a Efetivação da Diretriz da Qualidade da Educação Superior. In: SOUZA NETO, Cláudio Pereira; SARMENTO, Daniel; BINENBOJM, Gustavo (coord.). Vinte Anos da Constituição Federal de 1998. Rio de Janeiro: Editora Lumen Juris, 2009, p. 782)

${ }^{174}$ Isso tendo em vista que a lógica da massificação inclui significativa mobilidade social para um segmento crescente da população, incluindo sistemas diversificados de educação superior na maior parte dos países, porém com uma queda geral nos parâmetros de qualidade acadêmica (ALTBACH, Philip G.; REISBERG, Liz; RUMBLEY, Laura E. Trends in Global Higher Education: Tracking an Academic Revolution, p. i).
} 
"à primeira vista, o setor privado no Brasil parece ter contribuído para com a equidade trazendo um rápido aumento no número de vagas nas universidades. É improvável que o setor público pudesse ter-se expandido na proporção que o setor privado o fez, mesmo se os recursos estatais não tivessem sido cortados. A existência de universidades particulares, com seus exames de admissão menos competitivos, horários flexíveis e, em alguns casos, localizadas em áreas fora dos centros metropolitanos, tornou possível que muitos brasileiros, que não poderiam fazê-lo de outro modo, obtivessem um diploma universitário. As universidades particulares estão, portanto, exercendo um papel na sociedade brasileira e claramente há uma forte demanda por elas por parte dos 'consumidores'. Entretanto, argumentaremos que o crescimento deste setor não tem de fato contribuído para a equidade no sistema educacional, particularmente a longo prazo." 175

A questão do direito à educação envolve necessariamente qualidade, já que o primeiro somente pode ser considerado realizado quando a segunda alcança um nível aceitável. Dessa forma, as preocupações com a qualidade não podem ser deixadas de lado como se entrincheiradas entre o elitismo e a inevitabilidade da perda de padrões quando a educação é estendida a todos. ${ }^{176}$ Portanto, em oposição aos argumentos de dirigentes dos grandes grupos de ensino de massa, ${ }^{177}$ o crescimento dos conglomerados, o número de vagas oferecidas e a classe social dos seus alunos não justificam o estabelecimento de níveis brandos de qualidade - "determinada pelo mercado", "relacionada somente ao ensino", "fiscalizada pelo aluno", etc. -, mas ao

\footnotetext{
${ }^{175}$ McDOWAN, Tristan. O crescimento da educação superior privada no Brasil: implicações para as questões de equidade, qualidade e benefício público, p. 7-8.

${ }^{176}$ McDOWAN, Tristan. Is There A Universal Right To Higher Education? British Journal of Educational Studies, v.60, n.2, 2012, p. 122

${ }^{177}$ Em debate na Comissão de Educação da Câmara dos Deputados, em 10 de outubro de 2013, Rodrigo Capelato, representante da Kroton Educacional, referindo-se ao debate sobre a fusão entre Kroton e Anhanguera, entendia não ser pertinente a discussão sobre a fusão em si, na medida em que o país teria problemas maiores a serem resolvidos antes. No raciocínio oferecido pelo representante do grupo, a questão principal seria o número limitado de alunos no ensino superior, sobretudo à distância, e não a concentração de alunos nas mãos das empresas educacionais em pauta. A resposta seria ampliar oferta, ou seja, discutir o modelo de expansão do setor privado e qualidade educacional seriam secundários nessa equação. Para justificar como inevitável a preocupação dos grupos educacionais com a prestação de uma educação de qualidade se escorou nas especificidades do mercado financeiro, de forma que os valores das suas ações não suportariam uma sequência de resultados ruins nas avaliações dos órgãos reguladores. Ao mesmo tempo, nega a interferência tanto do mercado na missão institucional, já que no seu conselho administrativo estariam vários educadores, quanto do capital estrangeiro na gestão do grupo, já que em um mercado extremamente regulado não sobraria espaço para tal possibilidade (CAPELATO, Rodrigo. Palestra, 10 Out. 2013. Comissão de Educação da Câmara dos Deputados. A Fusão entre as Empresas Kroton Educacional do Grupo Pitágoras, e Anhanguera Educacional, e seu impacto na qualidade do Ensino Brasileiro. Disponível em: http://www2.camara.leg.br/atividade-legislativa/comissoes/comissoespermanentes/cec/reunioes/videoArquivo?codSessao=46059\&codReuniao=33860.)
} 
contrário, reforçam as necessidades de um papel ativo do Estado como regulador de um setor cujo crescimento e cujas políticas são cada vez mais definidos pelo mercado, em especial pelo mercado financeiro, lastreado na necessidade de lucros crescentes e imediatos. É preciso que o Estado seja capaz de garantir que as promessas dos grupos educacionais de massa voltadas à captação de alunos sejam cumpridas, assegurando parâmetros mínimos de qualidade que não estejam subjugados unicamente ao lucro.

\subsection{Influência do direito internacional}

As entrevistas buscaram também averiguar o reconhecimento por parte dos entrevistados da repercussão de normativas internacionais sobre o processo de comercialização da educação superior e sobre a gestão das instituição de educação superior. Face às respostas negativas foi perguntado se acordos e compromissos na OMC ou em acordos preferenciais de comércio alterariam o quadro regulador atual. De forma praticamente unânime, não foi reconhecida influência alguma do direito internacional no processo de comercialização da educação superior no país. Foi mencionada em um primeiro momento a centralidade da regulamentação doméstica na matéria e, em uma segunda hipótese, no caso de instituições adquiridas por grupos estrangeiros, o impacto dos costumes e práticas empresariais ou da legislação dos Estados Unidos, país de origem desses grupos.

Quanto ao não reconhecimento do envolvimento de regras internacionais e o protagonismo da legislação doméstica:

\footnotetext{
“as discussões sobre negócios internacionais volta e meia fazem menção às atividades educacionais, mas pouco ou nada avançaram nesse sentido. As negociações envolvendo as entidades educacionais terminam, desta forma, orientadas pelas normas específicas de cada País, sobretudo as normas de direito empresarial, tributário e educacional.",178
}

E ainda:

“... não existe por parte da maioria dos países restrição para aquisições de instituições educacionais. A transação é realizada livremente entre as mantenedoras sem intervenção do Governo. Recentemente no Brasil, o CADE - Conselho Administrativo de Defesa Econômica analisa o

\footnotetext{
${ }^{178}$ Entrevistado 09 (Consultor do setor privado educacional).
} 
negocio sobre o ponto de vista de concentração e de domínio de mercado, para evitar que uma instituição tenha exclusividade em determinada região. É uma análise de teor econômico. Sei também que o MEC por meio de uma autarquia (INSAES - Instituto Nacional de supervisão e avaliação do ensino superior) que está sendo discutida no Congresso Nacional, pensa em analisar as aquisições sobre o ponto de vista educacional. Não há normas entre Governos com respeito a atividade educacional. Apenas as questões de domínio de mercado são agora analisadas pelo CADE."179

Em contrapartida, nas instituições que agora formam parte de grupos internacionais, há relato da influência de costumes trazidos pelos novos investidores sob a forma de códigos de conduta e práticas cotidianas. Assim, o Entrevistado 01 refere um código de conduta universal para as instituições do grupo, em boa parte proveniente da legislação doméstica norte-americana, que impede, por exemplo, que os professores recebam livros de editoras, para evitar que sejam condicionados pela propaganda; ou que gestores contratem parentes para funções na instituição, ainda que com qualificação suficiente para o cargo, a fim de eludir o nepotismo. ${ }^{180}$ Do mesmo modo, o Entrevistado 04 fala de uma estrutura organizada para oferecer uma melhor experiência para o aluno-consumidor, nos moldes consumeristas adotados pelas demais instituições do grupo, e a criação de uma pró-reitoria de assuntos estudantis para que a experiência do estudante seja a melhor possível durante os anos de faculdade. ${ }^{181}$

Sem que o país tenha compromissos internacionais de liberalização em serviços educacionais, e considerando que estes, em acordos de comércio, além de garantirem tratamento nacional e acesso a mercados a investidores estrangeiros, asseguram também uma certa estabilidade regulatória, foi questionado quais seriam os possíveis interesses dos grupos educacionais domésticos em relação à assinatura de acordos preferenciais de comércio pelo Brasil:

\footnotetext{
"não vejo, no momento, acentuado interesse dos grupos brasileiros em relação acordos de comércio na área da educação superior. Penso, todavia, que a oferta de educação à distância, a mobilidade de profissionais da educação e alunos entre instituições brasileiras e

${ }^{179}$ RODRIGUES, Gabriel Mário (Presidente da Associação Brasileira de Mantenedoras de Ensino Superior).

${ }^{180}$ Entrevistado 01 (Pró-Reitor da Instituição A adquirida por grupo estrangeiro).

${ }^{181}$ Entrevistado 04 (Coordenador de Curso da Instituição C adquirida por grupo estrangeiro).
} 
estrangeiras e a transferência de tecnologias educacionais deverá conduzir os grupos nacionais a alguma iniciativa nesse sentido."182

A resposta do Entrevistado 10, consultor do setor privado educacional, parece estar de acordo com os debates nas entidades representativas do setor privado, no qual ainda não se tem notícias sobre o interesse dos grupos domésticos em investir no exterior. Tais grupos posicionam-se contra qualquer limitação à participação do capital estrangeiro em instituições de ensino no Brasil, ainda que não tenham clara a conveniência ou não de assumir compromissos de liberalização em acordos de comércio.

\subsection{Controle sobre a participação do capital estrangeiro}

Se não é reconhecida no direito internacional qualquer forma legal que se imponha ao processo de comercialização da educação superior no Brasil, surge a necessidade, então, de determinar na regulamentação doméstica a existência ou não de um tratamento discriminatório em relação ao capital estrangeiro. Assim, sobre a presença de regras referentes à educação superior que gerem um tratamento discriminatório entre um grupo estrangeiro e um grupo nacional disposto a investir no setor, o Entrevistado 10 afirma:

"não identifico nos atos regulatórios da educação superior brasileira nenhuma regra que permita um tratamento discriminatório ao capital estrangeiro ou a grupos internacionais. Observo, apenas, o ranço ideológico em alguns pronunciamentos de autoridades do Ministério da Educação e de alguns parlamentares oriundos do meio acadêmico público, contudo não creio que isso permanecerá a longo prazo." 183

De maneira complementar, frente ao contexto já relativamente liberalizado no Brasil, o entrevistado amplia o comentário em torno do espaço para

\footnotetext{
${ }^{182}$ Entrevistado 10 (Consultor do setor privado educacional).

${ }^{183}$ Entrevistado 10 (Consultor do setor privado educacional).
} 
alguma forma de controle sobre a presença de investidores estrangeiros no setor educacional:

\begin{abstract}
"penso que o controle deverá sempre existir nos aspectos relativos ao cumprimento da legislação e normas brasileiras para a educação superior. Cumpridas, especialmente, as diretrizes curriculares nacionais, não vejo necessidade de outro tipo de controle, exceto os tributários e fiscais. Em plena era da globalização e da sociedade do conhecimento, a limitação do ingresso de capitais estrangeiros, por exemplo, não vai contribuir em nada para a elevação da qualidade desse nível de ensino. A concorrência será sempre salutar, incentivando todos os atores desse processo à inovação, à criatividade." $" 184$
\end{abstract}

No caminho contrário, o Projeto de Lei $\mathrm{n}^{\circ} 2138$, apresentado no dia 2 de outubro de 2003, de autoria do Deputado Federal Ivan Valente, então no PT/SP, hoje vinculado ao PSOL/SP, trata da proibição do ingresso do capital estrangeiro nas instituições educacionais brasileiras com fins lucrativos. Tal medida não se aplicaria aos recursos para pesquisa e extensão, ou às verbas destinadas ao apoio a instituições denominadas educacionais, comunitárias ou filantrópicas. A proposta é calcada basicamente no processo de mercantilização da educação, com o crescente interesse estrangeiro nos setor doméstico; e na contradição entre a alta rentabilidade oferecida aos investidores estrangeiros e questões de cunho cultural e político. Nesse sentido, "a propriedade estrangeira das instituições de ensino levará à disseminação de ideias e valores dissociados dos interesses nacionais", ${ }^{185}$

Ao Projeto de Lei apresentado pelo Deputado Ivan Valente foram apensados, respectivamente, em 23 de novembro de 2009, o Projeto de Lei $\mathrm{n}^{\circ}$ 6358/2009, de autoria do Deputado Federal Wilson Picler (PDT/PR) ${ }^{186}$; e, em 31 de março de 2010, o Projeto de Lei n ${ }^{\circ}$ 7040/2010, de autoria da Deputada Federal Alice Portugal ( $\mathrm{PC}$ do $\mathrm{B} / \mathrm{BA})^{187}$. O primeiro prevê a obrigatoriedade de que $51 \%$ do capital

\footnotetext{
${ }^{184}$ Entrevistado 10 (Consultor do setor privado educacional).

${ }^{185}$ BRASIL. Projeto de Lei no 2138, de 2003, pelo Deputado Ivan Valente (PSOL/SP). Disponível em: http://www.camara.gov.br/proposicoesWeb/prop_mostrarintegra?codteor $=168570 \&$ filename $=$ Tramitac ao-PL+2138/2003.

${ }^{186}$ BRASIL. Projeto de Lei n ${ }^{\circ}$ 6358, de 2009, pelo Deputado Wilson Picler (PDT/PR). Disponível em: http://www.camara.gov.br/proposicoesWeb/prop mostrarintegra?codteor=710779\&filename=PL+6358 /2009.

${ }^{187}$ BRASIL. Projeto de Lei no 7040 , de 2010, pela Deputada Alice Portugal (PCdoB/BA). Disponível em:
} 
votante das mantenedoras de instituições privadas de educação básica ou superior sejam reservados, direta ou indiretamente, a brasileiros natos ou naturalizados.

No mesmo sentido, o Projeto de Lei $\mathrm{n}^{\mathrm{o}} 7040 / 2010$ busca vedar a aquisição de instituições de ensino superior brasileiras por grupos estrangeiros, salvo via associação do capital estrangeiro a capitais nacionais, quando a participação acionária do primeiro nas instituições de ensino superior brasileiras fique limitada a $10 \%$ do capital total.

Em suas respectivas exposições de motivos, os três projetos de lei apontam o risco da desnacionalização do ensino superior, dada a ausência de impedimentos legais para a participação de capitais estrangeiros nas instituições de educação superior do país. Por outro lado, procuram, diferenciar o processo de mercantilização da desejada internacionalização das instituições nacionais, com fluxo de informações e mobilidade de estudantes, docentes e técnicos entre os países.

Após outras movimentações, em 25 de abril de 2012, o Projeto de Lei $n^{\circ}$ 2138/2003, de Ivan Valente, teve um parecer favorável do Relator, Deputado Paulo Rubem Santiago (PDT/PE), na Comissão de Educação e de Cultura (CEC) ${ }^{188}$, porém com a rejeição dos Projetos de Lei $n^{\circ}$ 6358/2009 e $n^{\circ} 7040 / 2010$, entendendo que o primeiro projeto seria incompatível com os demais. No dia 23 de maio de 2012 foi apresentado o Voto em Separado n 1 CEC, pelo Deputado Izalci (PR/DF).

Assinado também pelos Deputados Alino Correa, Valdir Maranhão e Paulo Freire, o voto em separado apresenta a contrariedade à limitação da participação do capital estrangeiro como amparada primeiramente no art. 209 da Constituição Federal, segundo o qual o ensino é livre à iniciativa privada se cumpridas as normas gerais da educação nacional, e submetida à autorização e à avaliação de qualidade pelo Poder Público. Assim, garantida a qualidade da educação pelo Poder Público, a discussão sobre a presença eventual de capital estrangeiro no conjunto dos recursos disponíveis para o funcionamento das instituições guardaria papel secundário. Em suma, o argumento é de que todas as instituições - nacionais ou

http://www.camara.gov.br/proposicoesWeb/prop_mostrarintegra?codteor=748162\&filename $=$ PL+7040 $\frac{12010 .}{188 \text { Parece }}$

${ }^{188}$ Parecer do Relator ${ }^{\mathrm{o}} 1$ CEC, 25 de abril de 2012, pelo Deputado Paulo Rubem Santiago (PDT/PE). Disponível

em: http://www.camara.gov.br/proposicoesWeb/prop mostrarintegra?codteor $=985515 \&$ filename $=$ Tramitac ao-PL+2138/2003. 
não - devem cumprir os requisitos de autorização e avaliação por parte do Poder

Público e respeito às normas gerais da educação, de tal modo que a origem dos recursos da mantenedora não teria maior importância. Para amparar tal raciocínio se recorre ao Artigo $1^{\circ}$, inciso IV, da Constituição Federal, combinado com o Artigo $5^{\circ}$, inciso XVIII, ambos interpretados em conjunto com o Artigo 170, parágrafo único. ${ }^{189}$

Considerando que o voto apresentado em separado na Comissão de Educação e Cultura, assinado por quatro deputados, representa quase em sua totalidade posições tornadas públicas por entidades representativas do setor privado educacional, em especial a ABMES, ${ }^{190}$ o Deputado Ivan Valente comenta a capacidade de influência dessas entidades junto ao Congresso Nacional e à Comissão de Educação:

\begin{abstract}
“o problema é que a Comissão de Educação também têm representantes do setor econômico que lucra com a lógica do ensino privado. É uma permanente tensão entre o apoio ao ensino público, gratuito e de qualidade, e a lógica da mercantilização da educação brasileira engendrada por deputados que são empresários da educação ou são financiados por eles. Trata-se de uma disputa duríssima, que envolve pesados interesses econômicos representados no Congresso Nacional e na própria Comissão
\end{abstract}

\footnotetext{
${ }^{189}$ Voto em Separado n ${ }^{\text {o }} 1$ CEC, 23 de maior de 2012, pelo Deputado Izalci (PR/DF). Disponível em: http://www.camara.gov.br/proposicoesWeb/prop mostrarintegra?codteor=994447\&filename=Tramitac ao-PL+2138/2003.

${ }^{190}$ Cristina Carvalho, referindo-se à tentativa de construir um aparato regulatório robusto para os estabelecimentos privados - definir regras claras às mantenedoras e aos estabelecimentos particulares participantes do Prouni - por meio do Plano de Desenvolvimento Institucional nos anteprojetos da reforma da educação superior, de 2004 e 2005, aponta na primeira versão do anteprojeto de reforma a tentativa de restrição àqueles estabelecimentos "constituídas sob a forma de sociedade com finalidades lucrativas, da origem de $70 \%$ do capital total e do capital votante, direta ou indiretamente, a brasileiros natos ou naturalizados há mais de dez anos, que deverão exercer, de forma obrigatória a gestão das suas atividades." Esse ponto em especial teria sido alvo de intensos protestos das entidades privadas, sobretudo da ABMES, que recorreu à sua assessoria jurídica para inviabilizar o regramento sob a alegação de inconstitucionalidade. Assim, "a versão seguinte assemelha-se a anterior no conteúdo, porém, no que diz respeito ao capital estrangeiro lucrativo excluiu-se o trecho no qual se determinava a obrigatoriedade do exercício da gestão das atividades da mantenedora a brasileiros natos ou naturalizados há mais de dez anos. Em contraposição, acrescentou-se a vedação ao modelo de franquia no sistema de educação superior. Novo afrouxamento nas restrições às empresas educacionais estrangeiras sobreveio na última versão. O limite ficou somente para $70 \%$ do capital votante e desconsiderou-se qualquer prazo mínimo para a naturalização dos proprietários das mantenedoras" [...]. "A flexibilidade do aparato regulatório exclusivo às mantenedoras foi bastante criticada pelo ANDES$\mathrm{SN}$, inclusive, pela definição de limites ao capital estrangeiro, já que, segundo o sindicato, não deveriam existir empresas educacionais, muito menos, com o aporte de capital estrangeiro. Ainda que os critérios à limitação ao capital estrangeiro tenham sido minimizados, esses não contemplaram nem os interesses do Fórum nem a proporção desejada pelo CRUB. Esse é um dos maiores impasses que impede a aprovação da norma jurídica. Como até o momento não há qualquer restrição ao ingresso de capital estrangeiro, assiste-se a um movimento ainda incipiente, com tendência de ampliação, de entrada via bolsa de valores por meio de participação societária nas empresas educacionais nacionais." (CARVAlHO, Cristina Helena Almeida de. A política pública para a educação superior no Brasil (1995-2008): ruptura e/ou continuidade? p. 204-206)
} 
de Educação. .... certamente que as entidades representativas do ensino privado exercem influência junto ao Congresso Nacional, por meio de lobistas e do próprio financiamento privado de campanhas eleitorais." 191

Nesse contexto, "todo projeto que, de alguma forma, vise impor limites ao poder econômico tem sérias dificuldades para ser aprovado no Congresso Nacional." 192 Não obstante, para identificar as estratégias dos investimentos internacionais no Brasil é essencial que se leve em conta sua inserção em um processo global de transnacionalização da educação. ${ }^{193}$ A tendência é supor que os investimentos educacionais estrangeiros serão de alta qualidade e preocupados com a qualidade de ensino, quando, na verdade, o que eles apresentam como novidade é uma outra perspectiva de gestão, com vantagens sobretudo negociais. Assim, prossegue o Deputado:

\begin{abstract}
"é importante ressaltar, também, ao contrário do que informa o voto em separado, que o nosso Projeto não é contrário ao intercâmbio cultural, educacional e acadêmico, é apenas contrário à colonização do conhecimento por empresas que não estão dispostas a divulgar o saber, mas apenas a lucrar com a educação brasileira. Harvard não vem para o Brasil. O que vem é o capital, são fundos, é nuvem de dinheiro interessados em lucrar com a venda de pacotes educacionais, tratadas pelo setor privado como uma 'mercadoria' com dado valor de mercado." 194
\end{abstract}

Para Valente, a entrada dos investidores estrangeiros no setor da educação não só não representa uma possibilidade de um acréscimo de qualidade, mas também amplia a capacidade de pressão das entidades representativas do setor privado educacional sobre o regulador. ${ }^{195} 196$ Com efeito, a literatura indica que a

\footnotetext{
${ }^{191}$ VALENTE, Ivan (Deputado Federal - PSOL/SP). Entrevistador: Lucas da Silva Tasquetto, 14. Mai. 2014.

${ }^{192}$ VALENTE, Ivan (Deputado Federal - PSOL/SP). Entrevistador: Lucas da Silva Tasquetto, 14. Mai. 2014.

${ }^{193}$ FÁVERO, Maria de Lourdes de A. A Dimensão Histórico-Política da Nova Lei de Diretrizes e Bases e a Educação Superior. In: CATANI, Afrânio Mendes (org.). Novas Perspectivas nas Políticas de Educaçao Superior na América Latina no Limiar do Século XXI. Campinas, SP: Editora Autores Associados, 1998, p. 61.

${ }^{194}$ VALENTE, Ivan (Deputado Federal - PSOL/SP). Entrevistador: Lucas da Silva Tasquetto, 14. Mai. 2014.

${ }^{195}$ Trabalhos sobre o setor privado educacional nos Estados Unidos apontam a arena política como o local onde os prestadores de educação superior com fins lucrativos terão uma chance real de alterar o panorama do ensino superior. $\mathrm{O}$ instrumento para tanto seria o uso do lobbying e as contribuições diretas de campanha para moldar as regulações e as políticas, que já têm se mostrado de grande significância para o setor (PUSSER, Brian; WOLCOTT, David A. A Crowded Lobby: Nonprofit and
} 
cadeia de instituições de ensino superior, na medida em que se estabelece globalmente, pode causar importante impacto sobre a formulação e implementação de políticas no âmbito nacional, de modo que o equilíbrio de poderes nos campos da educação superior no país podem ser significativamente alterados no futuro. ${ }^{197}$

\subsection{Marco regulatório sobre a educação superior: regulação, avaliação e supervisão}

A partir das categorias centrais utilizadas pelo direito do comércio internacional para a liberalização do comércio de serviços, no que se refere à educação superior no Brasil não há impedimentos específicos ao "acesso ao mercado" de prestadores estrangeiros de serviços educacionais pelo simples fato de não serem nacionais, e tampouco estes recebem um tratamento discriminatório em relação àquele concedido em condições similares aos prestadores domésticos. Assim, não há reserva de mercado para as instituições nacionais. Ao ingressarem no Brasil, por meio da aquisição de instituições de ensino superior domésticas - transferência de mantença - ou de ativos de grupos educacionais domésticos com capital aberto na bolsa de valores, os investidores estrangeiros se sujeitam às mesmas condições e ao cumprimento do mesmo marco regulatório apresentados aos prestadores domésticos de serviços educacionais.

For-Profit Universities and the Emerging Politics of Higher Education. In: BRENEMAN, David W.; PUSSER, Brian; TURNER, Sarah E. (edit.). Earnings from Learning: The Rise of For-Profit Universities. Albany: State University of New York Press, 2006, p. 168).

${ }^{196}$ No Brasil, por exemplo, sob forte pressão de instituições privadas com fins lucrativos, foi colocado em pauta em 2011 o Projeto de Lei 220/2010 (Retrocesso no ensino superior. O Estado de São Paulo, 12 Jul. 2011. Disponível em: http://www.estadao.com.br/noticias/impresso,retrocesso-no-ensinosuperior,743708,0.htm. Acesso em 13 Jul. 2011). A proposta trazia em seu bojo a alteração do Artigo 66 da LDB, que exige que professores universitários tenham diploma de pós-graduação, especialização, mestrado ou doutorado. $O$ que se propunha era a dispensa da obrigatoriedade de mestrado e doutorado para professores atuarem nas universidades, de modo que, desde que contratados em regime temporário, docentes de instituições públicas e privadas poderiam lecionar apenas com o diploma de graduação. Apoiado por grandes grupos educacionais, como a Anhanguera Educacional, com investidores estrangeiros por trás, a medida foi rechaçada pelo Ministério da Educação Ministro rejeita projeto que dispensa mestrado a professor universitário. Portal MEC, 13 Jul. 2011. Disponível em: http://portal.mec.gov.br/index.php?option=com_content\&view=article\&id=16871. Acesso em 13 Jul. 2011).

${ }^{197}$ GOMES, Alfredo M.; ROBERTSON, Susan L.; DALE, Roger. The social condition of higher education: globalisation and (beyond) regionalisation in Latin America, p. 233-234. 
Principalmente no que se refere à entrada e à garantia da qualidade, os limites para a atuação de instituições de ensino superior são dados pela Constituição Federal e pela legislação específica. A Constituição Federal de 1988, no artigo 209, ao mesmo tempo em que coloca o ensino como livre à iniciativa privada, também estabelece diretrizes para o Estado ao sujeitar nos seus incisos a atuação da iniciativa privada ao cumprimento das normas gerais da educação nacional e à autorização e avaliação de qualidade pelo Poder Público.

As instituições privadas de ensino, no artigo 20 da Lei de Diretrizes e Bases da Educação Nacional, de 1996, são classificadas em categorias específicas, em um elenco no qual as "instituições particulares em sentido estrito" - lucrativas ou não - são aquelas instituídas e mantidas por uma ou mais pessoas físicas ou jurídicas de direito privado que não apresentem as características de instituições privadas comunitárias, confessionais e filantrópicas, estas sem fins lucrativos e previstas nos incisos II, III e IV. ${ }^{198}$ Assim, as mantenedoras de instituições privadas de ensino superior podem assumir qualquer das formas admitidas em direito, de natureza civil ou comercial, de acordo com o artigo $7^{\circ}$-A da Lei $\mathrm{n}^{\circ}$ 9.131, de 24 de novembro de 1995, incluído pela Lei $\mathrm{n}^{\circ} 9.870$, de 23 de novembro de 1999 - matéria antes regulamentada pelo Decreto $n^{\circ} 2207 / 97$, substituído na sequência pelo Decreto $n^{\circ}$ 2306/97. ${ }^{199}$ É permitido a elas, então, assumir finalidade lucrativa, respondendo a partir daí como entidades comerciais, ainda que de natureza civil. ${ }^{200}$

No que diz respeito aos atos autorizativos, o artigo $9^{\circ}$ da LDB, em seus incisos VIII e IX, concede à União a incumbência de assegurar o processo nacional de avaliação das instituições de educação superior; e de autorizar, reconhecer, credenciar, supervisionar e avaliar, respectivamente, os cursos das instituições de educação superior e os estabelecimentos do seu sistema de ensino. Os prazos para a autorização e o reconhecimento de cursos, e o credenciamento de instituições de

\footnotetext{
${ }^{198}$ BRASIL. Lei no 9.394, de 20 de dezembro de 1996. Estabelece as diretrizes e bases da educação nacional. Disponível em: www.planalto.gov.br/ccivil_03/Leis/L9394.htm. Acesso em 15 Nov. 2013.

${ }_{199}$ BRASIL. Lei ${ }^{\circ}$ 9.131, de 24 de novembro de 1995. Disponível em: Disponível em: www.planalto.gov.br/ccivil_03/Leis/L9131.htm. Acesso em 19 Abr. 2013.

${ }^{200}$ Sobre a figura da instituição particular de ensino em sentido estrito e a permissão dada para que esta operasse com fins lucrativos, Sampaio entende que: "para alguns, a alteração legal reflete a orientação neoliberal do governo FHC e, coerentemente a ela e com as orientações de agências multilaterais, foi o empurrão que faltava para a mercantilização da educação superior brasileira. Da perspectiva dos formuladores de políticas educacionais da época, o Decreto 2.306/97 apenas reconheceu uma situação de fato, entendendo que era necessário tornar explícita a heterogeneidade do setor privado em termos de direitos e deveres em relação ao Estado" (SAMPAIO, Helena. O Setor Privado de Ensino Superior no Brasil: Continuidades e Transformações, p. 32).
} 
educação superior, serão limitados, renovados periodicamente após processo regular de avaliação.

Em 2004, a Lei no 10.861 cria o Sistema Nacional de Avaliação da Educação Superior (SINAES), responsável pela avaliação interna e externa das instituições de ensino superior, avaliação dos cursos de graduação e do desempenho acadêmico dos estudantes de cursos de graduação, cuja coordenação e supervisão fica a cargo da Comissão Nacional de Avaliação da Educação Superior (CONAES). O SINAES reúne informações das avaliações institucionais e dos cursos, bem como do Exame Nacional de Desempenho de Estudantes (ENADE), com os seus resultados constituindo referencial básico dos processos de regulação e supervisão da educação superior, neles compreendidos o credenciamento e a renovação de credenciamento de instituições de educação superior, a autorização, o reconhecimento e a renovação de reconhecimento de cursos de graduação. ${ }^{201}$

O marco regulatório básico sobre a educação superior em torno da LDB e da Lei do SINAES já apresentava fundamentos jurídicos suficientes para que os processos regulatórios fossem realizados como uma atividade regular e periódica de avaliação. ${ }^{202}$ Mesmo antes da Lei do SINAES algumas avaliações já vinham sendo realizadas - Exame Nacional de Cursos (Provão) -, contudo sem condicionar os atos autorizativos à avaliação satisfatória de instituições e cursos. ${ }^{203} \mathrm{~A}$ reversão desse quadro para a exata aplicação do art. 209 da Constituição Federal, onde "autorização" e "avaliação de qualidade pelo Poder Público" se encontram juntas, de modo que uma não se sustenta sem a outra, dá ensejo ao que se chamou de "novo marco regulatório da educação superior" 204 .

201 BRASIL. Lei $\mathrm{n}^{\circ} 10.861$, de 14 de abril de 2004. Disponível em: www.planalto.gov.br/ccivil_03/_ato2004-2006/2004/Lei/L10.861.htm. Acesso em: 12 Nov. 2013.

${ }^{202}$ BUCCI, Maria Paula Dallari. O Art. 209 da Constituição 20 anos Depois, p. 791.

${ }^{203}$ Nesse sentido, prossegue Maria Paula Dalarri Bucci: "avaliações insatisfatórias, no passado recente, não eram impeditivas, por exemplo, de atos de ampliação do credenciamento de faculdades e universidades para novas localidades. Diga-se, aliás, que esse foi um dos principais expedientes de expansão da educação superior no período entre 1997 e 2002, por meio do credenciamento de novas unidades, na condição de campus fora de sede, de instituições já em funcionamento, muitas delas notoriamente distantes de padrão satisfatório de qualidade. A concepção por trás desse arranjo era de que a indicação prévia de qualidade não devia ser tratada como problema do Poder Público, mas competia ao mercado. Sustentava-se que, com a realização do Provão, haveria informação suficiente para os alunos, que, sendo 'maiores e vacinados', fariam livremente suas escolhas. Não era o que ocorria, contudo. Dado o valor intrínseco do diploma de formação superior em nossa cultura, os maus cursos mantiveram sua clientela, pautando-se a escolha pelas possibilidades econômicas e não pelos indicadores de qualidade.” (O Art. 209 da Constituição 20 anos Depois, p. 791).

${ }^{204}$ BUCCI, Maria Paula Dallari. O Art. 209 da Constituição 20 anos Depois, p. 783. 
Nesse sentido, o Decreto $\mathrm{n}^{\circ}$ 5.773, de 09 de maio de 2006, é documento fundamental, ao dispor sobre o exercício das funções de regulação, avaliação e supervisão das instituições de educação superior e cursos superiores de graduação, reafirmando o papel do SINAES como referencial básico para os processo de regulação e supervisão da educação superior, a fim de promover a melhoria da sua qualidade. ${ }^{205} \mathrm{Em}$ comum está o objetivo de superar uma abordagem formalista anterior, mais interessada nos aspectos documentais dos processos de regulação e na abertura de instituições e cursos, com um fraco controle posterior sobre as reais condições destes. $^{206}$

O funcionamento de instituição de educação superior e a oferta de curso superior dependem de ato autorizativo do Poder Público, cujas modalidades previstas no decreto abarcam os atos administrativos de credenciamento e recredenciamento de instituições de educação superior e de autorização, reconhecimento e renovação de reconhecimento de cursos superiores, bem como de suas respectivas modificações, limitados temporalmente e sujeitos a renovação, tal como no texto da LDB. De acordo com sua organização e prerrogativas acadêmicas, as instituições de educação superior são credenciadas como faculdades, centros universitários e universidades. O início do funcionamento de uma instituição está condicionado à edição prévia de ato de credenciamento pelo Ministério da Educação, e será originalmente credenciada como faculdade. Seu posterior credenciamento como centro universitário ou universidade dependerá de seu funcionamento regular e com padrão satisfatório de qualidade. Para faculdades e centros universitários o primeiro credenciamento tem prazo máximo de três anos, enquanto para universidades o prazo é de cinco anos.

O pedido de credenciamento deve ser instruído com documentos da mantenedora, como comprovantes e certidões, e documentos da instituição de educação superior, mais especificamente o comprovante de recolhimento da taxa de avaliação in loco, o plano de desenvolvimento institucional, o regimento ou estatuto, e a identificação dos integrantes do corpo dirigente, com a experiência acadêmica e administrativa de cada um.

\footnotetext{
205 BRASIL. Decreto $\mathrm{n}^{\circ}$ 5.773, de 09 de maio de 2006. Disponível em: www.planalto.gov.br/ccivil 03/_Ato2004-2006/2006/Decreto/D5773.htm. Acesso em 17 Nov. 2013. ${ }^{206}$ BUCCI, Maria Paula Dallari. O Art. 209 da Constituição 20 anos Depois, p. 791-792).
} 
De outro lado, fundamental no processo de fusões e aquisições no país, toda transferência de mantença de qualquer instituições de educação superior deve ser submetida ao Ministério da Educação. Além do instrumento jurídico que dá base à transferência de mantença, o novo mantenedor deve apresentar os mesmos documentos apresentados pela mantenedora para o pedido de credenciamento. $\mathrm{O}$ pedido tramitará na forma de aditamento ao ato de credenciamento ou recredenciamento da instituição, e não será admitido caso o postulante tenha recebido penalidades - diretamente ou por qualquer entidade mantida - em matéria de educação superior, perante o sistema federal de ensino, nos últimos cinco anos.

Considerando as exigências regulatórias e o tempo para a entrada no "mercado" educacional, o ingresso de investidores estrangeiros por meio de fusões e aquisições no país em vez do estabelecimento de novas instituições é um caminho que parece natural e funciona como um atalho no caso do ensino superior privado. Ainda que enfrente restrições no campo da defesa da concorrência, passíveis de serem oferecidas pelo CADE, as aquisições representam um meio mais rápido de acesso a novas regiões e garantem o crescimento das grandes redes educacionais, sejam elas domésticas ou estrangeiras. ${ }^{207}$ Além de evitar um procedimento burocrático maior e o período para autorização, em muitos casos, os grupos adquirentes também assumem como um ativo intangível a reputação da instituição adquirida, consolidada durante os anos de funcionamento desta. ${ }^{208}$

No que tange à avaliação, por sua vez, nos termos do artigo 33, da Portaria Normativa $n^{\circ} 40$, de 12 de dezembro de 2007, o ciclo avaliativo envolve a realização periódica de avaliação de instituições e cursos superiores, com referência nas avaliações trienais de desempenho de estudantes, as quais subsidiam, respectivamente, os atos de recredenciamento e de renovação de reconhecimento. As avaliações são orientadas por indicadores de qualidade e geram conceitos de avaliação de instituições e cursos superiores, expedidos periodicamente pelo INEP. Expressos em uma escala de cinco níveis, os conceitos de avaliação e os indicadores de qualidade iguais ou superiores a 3 indicam qualidade satisfatória e podem dispensar a avaliação in loco para os cursos bem avaliados, enquanto todas as instituições com notas 1 e 2 serão visitadas por técnicos do MEC e ficam sujeitas a penalidades. Os

\footnotetext{
${ }^{207}$ GARCIA, Carolina Policarpo. Efeito rede em fusões no ensino superior, p. 8.

${ }^{208}$ GARCIA, Carolina Policarpo. Efeito rede em fusões no ensino superior, p. 12-13.
} 
indicadores de qualidade, calculados pelo INEP a partir dos resultados do ENADE e dos demais insumos presentes nas bases de dados do MEC, são o Conceito Preliminar de Curso (CPC), para os cursos superiores; o Índice Geral de Cursos Avaliados da Instituição (IGC), para as instituições de educação superior; e o conceito obtido a partir dos resultados do ENADE, para o desempenho de estudantes.

Calculado no ano seguinte ao da realização do ENADE de cada área, o CPC considera a avaliação de desempenho de estudantes - conceito ENADE -, corpo docente, infraestrutura, recursos didático-pedagógicos e demais insumos. O IGC, por sua vez, é calculado anualmente, considerando a média ponderada dos CPCs dos cursos avaliados da instituição durante o triênio de referência, no caso da graduação, e a média ponderada dos conceitos de avaliação atribuídos pela CAPES na última avaliação trienal disponível, no caso dos programas de pós-graduação stricto sensu. ${ }^{209}$

As atividades de supervisão ficam a cargo da Secretaria de Educação Superior, da Secretaria de Educação Profissional e Tecnológica e da Secretaria de Educação a Distância. Face a eventuais deficiências identificadas pela avaliação a partir dos conceitos e indicadores de qualidade acima descritos, após o prazo para o saneamento das mesmas e mediante processo administrativo podem ser aplicadas penalidades, que vão da desativação de cursos e habilitações, intervenção na instituição, suspensão temporária de prerrogativas da autonomia, até o descredenciamento da instituição. Assegura-se, assim, que indicadores de qualidade insuficientes nos processos de avaliação tenham consequências diretas no que diz respeito à regulação.

\subsection{A criação do Instituto Nacional de Supervisão e Avaliação da Educação Superior (INSAES) e a análise diferenciada no CADE dos casos de fusões e aquisições no setor educacional}

O movimento do setor privado com fins lucrativos mobilizou o Poder Público em ao menos duas frentes com vista a ampliar a capacidade de ação do Estado em relação ao acentuado processo de fusões de aquisições no setor. Tramita no

\footnotetext{
${ }^{209}$ BRASIL. Portaria Normativa MEC $\mathrm{n}^{\circ} 40$, de 12 dezembro de 2007. Disponível em: http://meclegis.mec.gov.br/documento/view/id/17. Acesso em: 10 Nov. 2013.
} 
Congresso Nacional o Projeto de Lei n. 4.372, que prevê a criação do INSAES, destinado sobretudo a dar maior agilidade nas análises de abertura e fechamento de instituições e cursos. Por outro lado, o MEC teria estabelecido uma parceria com o CADE, oferecendo ao último as informações necessárias no plano concorrencial para evitar autorizações de fusões e aquisições que tragam prejuízo à qualidade do ensino. $^{210}$

As medidas reforçam o controle do Estado sobre o setor da educação superior no Brasil, em uma lógica onde regulação, avaliação e supervisão encontramse articuladas, no espírito trazido pelo "novo marco regulatório da educação superior". Para o então ministro, Aloizio Mercadante, o MEC precisa de uma estrutura maior para cumprir o seu papel de regulador com mais agilidade e rigor. Além da análise da infraestrutura, da carreira docente, da estrutura didática e de outros compromissos necessários para garantir a qualidade de ensino, o Ministério demandaria agilidade para tomar medidas disciplinares quando indispensáveis. ${ }^{211} \mathrm{Na}$ perspectiva do Secretário de Regulação e Supervisão da Educação Superior do MEC, Jorge Messias, a criação do INSAES não esvaziaria os poderes da própria pasta tampouco do INEP, bem como não trará maiores interferências ao trabalho do CADE. Ao INEP ainda caberia parte dos instrumentos de avaliação, com o ENADE e com a parte de pesquisas e estatísticas, além do Exame Nacional do Ensino Médio (ENEM) e da avaliação da educação básica. ${ }^{212}$

Apresentado pelo Poder Executivo em 31 de agosto de 2012, o Projeto de Lei ${ }^{\circ} 4.372$ atualmente tramita em regime de prioridade, aguardando o parecer do relator na Comissão de Constituição e Justiça e de Cidadania (CCJC). Antes disso tramitou pela Comissão de Educação (CE), Comissão de Trabalho, de Administração e Serviço Público (CTASP) e Comissão de Finanças e Tributação (CFT), chegando à CCJC somente em 08 de agosto de 2014. Nos moldes do projeto original, o INSAES será uma autarquia federal, com autonomia administrativa e financeira, vinculado ao

\footnotetext{
${ }^{210}$ MÁXIMO, Luciano. MEC e Cade unem-se na regulação universitária. Valor Econômico, 30 Nov. 2012. Disponível em: http://www.valor.com.br/brasil/2923626/mec-e-cade-unem-se-na-regulacaouniversitaria.

${ }^{211}$ MÁXIMO, Luciano. MEC e Cade unem-se na regulação universitária.

${ }^{212}$ CASTRO, Grasielle. Criação do Insaes avança: o órgão será uma espécie de agência reguladora da educação superior privada, com poder de autorizar a criação de cursos, Correio Braziliense, 13 Dez. 2012. Disponível em: http://www.correiobraziliense.com.br/app/noticia/euestudante/ensino ensinosuperior/2012/12/13/ensino_ensinosuperior_interna,338815/criacao-do-insaesavanca.shtml. Acesso em 26 de fevereiro de 2013.
} 
Ministério da Educação. As receitas que tornarão viável seu funcionamento serão provenientes principalmente das dotações consignadas no Orçamento-Geral da União, do produto da arrecadação das taxas de avaliação in loco - que, instituída pela Lei $\mathrm{n}$. 10.870, de 2004, passa a ser revertida em favor do INSAES, pelas avaliações periódicas que realizar, quando solicitado credenciamento, recredenciamento ou acreditação de instituição de educação superior e autorização, reconhecimento, renovação de reconhecimento ou acreditação de cursos de graduação e sequenciais - e de supervisão, e das multas aplicadas no exercício das atividades de supervisão.

Como finalidade geral, o INSAES terá como responsabilidade a supervisão e avaliação das instituições de educação superior e cursos de educação superior no sistema federal de ensino, bem como a certificação de entidades beneficentes que atuem na área de educação superior e básica. Entre suas competências específicas estão "formular, desenvolver e executar as ações de supervisão e avaliação de instituições de educação superior e cursos de educação superior no sistema federal de ensino, de acordo com as diretrizes propostas pelo Ministério da Educação, e em consonância com o Plano Nacional de Educação" (Art. 3, I); “expedir instruções e estabelecer procedimentos para a aplicação das normas relativas à sua área de competência, de acordo com as diretrizes do Ministério da Educação" (Art. 3, II); autorizar, reconhecer e renovar o reconhecimento de cursos de graduação e sequenciais (Art. 3, III); "instruir e exarar parecer nos processos de credenciamento e recredenciamentos de instituições de educação superior" (Art. 3, IV); "acreditar instituições de educação superior e cursos de graduação" (Art. 3, V); "realizar avaliações in loco referentes a processos de credenciamento e recredenciamento de instituições de educação superior e de autorização, reconhecimento e renovação de reconhecimento de cursos de graduação e sequenciais, e diligências para verificação das condições de funcionamento dessas instituições e cursos" (Art. 3, VI); e "supervisionar instituições de educação superior e cursos de graduação e sequenciais, quanto ao cumprimento da legislação educacional e à indução de melhorias dos padrões de qualidade da educação superior, aplicando as penalidades e instrumentos previstos na legislação" (Art. 3, VII); "decretar intervenção em instituições de educação superior, e designar interventor, nos termos de lei específica” (Art. 3, VIII); “ constituir e gerir sistema público de informações cadastrais de instituições, cursos, docentes e discentes da educação superior, e 
disponibilizar informação sobre a regularidade e qualidade das instituições e cursos da educação superior e a condição de validade de seus diplomas" (Art. 3, XI); "aprovar previamente aquisições, fusões, cisões, transferências de mantença, unificação de mantidas ou descredenciamento voluntário de Instituições de Educação Superior integrantes do sistema federal de ensino" (Art. 3, XII); e "articular-se, em sua área de atuação, com instituições nacionais, estrangeiras e internacionais, mediante ações de cooperação institucional, técnica e financeira bilateral e multilateral” (Art. 3, XIII).

Com essas atividades sob sua competência, o Instituto não só assume as atribuições da SERES, como também fica responsável pelo processo de avaliação in loco das instituições federais e privadas de educação superior e de seus cursos de graduação, a cargo até então do INEP. Na exposição de motivos que encaminha à apreciação da Presidenta a proposta de Projeto de Lei que cria o INSAES, assinada pelos(as) então Ministros(as) do Planejamento, Orçamento e Gestão, da Educação e da Fazenda, é apontada a necessidade de profundas alterações na estrutura do Ministério da Educação com o intuito de atingir e manter um elevado padrão de qualidade na educação superior face à ampliação quantitativa da rede de instituições de ensino e cursos por ela oferecidos. ${ }^{213}$

Nesse sentido, ao integrar em um só órgão as atividades de avaliação e supervisão da educação superior, a criação do INSAES responderia a uma maior otimização de recursos e integração de processos, bem como à dinâmica estabelecida pelo SINAES. Tal sistema faz da avaliação institucional externa de cursos e instituições de educação superior o referencial básico para os processos de regulação e supervisão da educação superior com fins de emissão dos atos regulatórios de autorização, reconhecimento e renovação de reconhecimento dos cursos de graduação e credenciamento e recredenciamento de instituições. Como parte dessa nova organização, com um corpo de servidores qualificados para tanto, o INSAES poderá ter ao menos um servidor efetivo em cada equipe de avaliação, somando-se aos

\footnotetext{
213 EMI 00199/2012 MP/MEC/MF. Disponível em: http://www.planalto.gov.br/ccivil_03/Projetos/ExpMotiv/EMI/2012/199\%20\%20MP\%20MEC\%20MF.htm. Acesso em 02 Mar. 2014.
} 
consultores ad hoc, de modo a garantir coerência conceitual, epistemológica e prática da avaliação in loco. ${ }^{214}$

Se, de um lado, o projeto de lei conta com o apoio de movimentos ligados ao estudantes e professores, visto o INSAES como um instrumento capaz de “combater o nocivo processo de financeirização e desnacionalização do ensino superior no Brasil", ${ }^{215}$ de outro, as entidades privadas criticam a possibilidade de ingerência nas instituições, ${ }^{216}$ a criação de uma nova taxa e a acumulação de poderes no instituto. ${ }^{217}$ Até então, são mais de 636 propostas de emendas ao projeto, que envolvem desde a mudança do nome de INSAES por INAES, suprimindo a expressão “de supervisão" e os poderes dela decorrentes, até a retirada da prerrogativa do novo órgão de aprovar previamente fusões e aquisições de instituições de ensino superior.

A reação ao INSAES reflete a resistência do setor privado da educação superior à regulação estatal na matéria, sobretudo na medida em que o novo órgão potencializa a capacidade de ação do Estado frente à expansão do setor. Além da articulação entre avaliação e supervisão das instituições, às funções específicas nessas áreas antes desempenhadas pela SERES e pelo INEP, aliam-se no INSAES a capacidade do órgão de "acreditar" instituições de educação superior e cursos de

214 Parágrafos 13, 14 e 15. In: EMI 00199/2012 MP/MEC/MF. Disponível em: http://www.planalto.gov.br/ccivil_03/Projetos/ExpMotiv/EMI/2012/199\%20\%20MP\%20MEC\%20MF.htm. Acesso em 02 Mar. 2014.

${ }^{215}$ Ver, por exemplo, a manifestação em defesa da aprovação do Insaes pela Confederação Nacional dos Trabalhadores em Estabelecimentos de Ensino (CONTEE): CONFEDERAÇÃO NACIONAL DOS TRABALHADORES EM ESTABELECIMENTOS DE ENSINO - CONTEE. Carta aberta em defesa da aprovação do Insaes, 12 Mai. 2014. Disponível em: http://contee.org.br/contee/index.php/2014/05/carta-aberta-em-defesa-da-aprovacao-doinsaes/\#.U4tx9S9a7Rw. Acesso em 16 Mai. 2014.

${ }^{216}$ De outro lado, considerando o impacto da criação do órgão para o setor educacional privado, Celso Frauches, consultor da ABMES, reage à introdução do termo "acreditar" no texto: "não há, no projeto, uma clara definição de 'acreditação' de IES e cursos e qual a diferença entre 'acreditar' e credenciar ou recredenciar IES, assim como entre 'acreditar' e autorizar, reconhecer ou renovar o reconhecimento de cursos de graduação. Acreditar é um verbo novo nesse cenário e a sua correta identificação e aplicação é necessária". Ao mesmo tempo, por fim, entende que, de forma geral, "as regras deixam de ser claras, transparentes, quando parte das ações do proposto Insaes serão desenvolvidas "de acordo com as diretrizes propostas pelo Ministério da Educação". Essa marota redação abre caminho para a justificativa de edição de portarias e similares criando regras, indicadores ou conceitos de qualidade não previstos em lei, para subsidiar os processos de credenciamento e recredenciamento de IES e de autorização, reconhecimento e renovação de reconhecimento de cursos, a exemplo do CPC (Conceito Preliminar de Curso) e do IGC (Índice Geral de Cursos), criados pela Portaria n ${ }^{\circ} 40 / 2007$, republicada em 29/12/2010" (FRAUCHES, Celso. Coluna do Celso Frauches: Educação superior comentada políticas, diretrizes, legislação e normas do ensino superior, ano 2, n. 73, 4 a 10 Set. 2012. Disponível em: http://www.abmes.org.br/abmes/noticias/detalhe/id/613. Acesso em 21 Mar. 2013).

${ }_{217}$ MOURA, Rafael Moraes. Entidades privadas atacam projeto que cria Insaes, $O$ Estado de São Paulo, 11 Dez. 2012. Disponível em: http://www.estadao.com.br/noticias/geral,entidades-privadasatacam-projeto-que-cria-insaes,972266. Acesso em 21 Mar. 2013. 
graduação e, especialmente relevante no atual contexto do setor educacional no Brasil, a prerrogativa de aprovar previamente não só fusões e aquisições, mas também cisões, transferências de mantença, unificação de mantidas e descredenciamento voluntário de instituições de ensino superior.

Por outro lado, a reação do MEC ao intenso processo de fusões e aquisições no setor da educação superior privada brasileira não se esgota no referido dispositivo que se insere entre a competência do INSAES. No plano concorrencial, a ideia é que o Ministério e o CADE trabalhem em conjunto nos processos relacionados à educação superior. ${ }^{218}$ Reconhecendo que haveria implicações no processo pedagógico, decorrente desses movimentos dos grupos educacionais privados, com uma tendência de continuidade do ritmo de aquisições em um setor ainda significativamente fragmentado, o secretário de regulação de ensino superior do MEC referiu-se à parceria entre o Ministério e o CADE como um passo para evitar fusões e aquisições que tragam prejuízos à qualidade do ensino. $\mathrm{O}$ acordo de cooperação técnica dá ao CADE todas as informações necessárias sob o aspecto concorrencial, em um momento no qual o órgão torna suas análises dos casos de aquisições no setor educacional cada vez mais pormenorizadas. ${ }^{219}$

O acordo de associação celebrado entre Kroton e Anhanguera em 20 de abril de 2013 foi aprovado, em caráter definitivo, pelo CADE em 14 de maio de 2014, mediante a celebração de um acordo em controle de concentrações (ACC). ${ }^{220} \mathrm{~A}$ aprovação da incorporação da totalidade do capital social da Anhanguera pela Kroton foi condicionada a ao menos dois níveis principais de compromissos. O primeiro com medidas que buscam garantir a concorrência com outras companhias, viabilizando concorrentes com escala suficiente para competir com a empresa fusionada e limitando a expansão desta. ${ }^{221} \mathrm{O}$ segundo procura assegurar maior qualidade na educação prestada pela companhia, por meio de metas objetivas.

\footnotetext{
${ }^{218}$ CASTRO, Grasielle. Criação do Insaes avança: o órgão será uma espécie de agência reguladora da educação superior privada, com poder de autorizar a criação de cursos, Correio Braziliense, 13 Dez. 2012. Disponível em: http://www.correiobraziliense.com.br/app/noticia/euestudante/ensino_ensinosuperior/2012/12/13/ensino_ensinosuperior_interna,338815/criacao-do-insaesavanca.shtml. Acesso em 26 de fevereiro de 2013.

${ }^{219}$ MÁXIMO, Luciano. MEC e Cade unem-se na regulação universitária.

220 KROTON-ANHANGUERA. Fato relevante, 14 Mai. 2014. Disponível em: http://ri.kroton.com.br/kroton2010/web/conteudo $p$ pt.asp?idioma $=0 \&$ tipo $=32868 \&$ conta $=28 \& \mathrm{id}=19270$ 8. Acesso em 18 Mai. 2014.

221 "Durante a instrução do caso foi diagnosticado que a operação resultaria em problemas concorrenciais em 171 cursos localizados em 55 municípios. Isso porque a Kroton e a Anhanguera
} 
O nível de compromissos que diz respeito aos problemas concorrenciais detectados e aos problemas concorrenciais potenciais traz como primeiro remédio proposto a alienação do Centro Universitário Leonardo da Vinci (Uniasselvi), pertencente à Kroton, que oferece cursos de graduação na modalidade de ensino à distância (EAD), além de operações presenciais em Santa Catarina e Mato Grosso. Nesse caso, em particular, o objetivo foi garantir um concorrente com escala suficiente para competir com a empresa fusionada no mercado de ensino à distância. Nos municípios onde foram detectados problemas concorrenciais, não resolvidos com a venda da Uniasselvi, a empresa que detiver maior participação de mercado não poderá ofertar vagas, enquanto a outra ficará impedida de expandir sua oferta de matrículas. Já em municípios onde as companhias não estão presentes simultaneamente, mas com pedidos em tramitação no MEC - ainda não autorizados que poderão levar à futura sobreposição, apenas uma das companhias poderá ofertar cursos nos quais existem preocupações concorrenciais. ${ }^{222}$

No plano da garantia da qualidade dos cursos de ensino à distância oferecidos pelas companhias, o ACC firmado estabeleceu parâmetros de qualidade sob os quais Kroton e Anhaguera assumiram o compromisso de investir na capacitação de professores e tutores, aumentando o percentual de professores mestres e doutores, e de incrementar as ferramentas disponíveis e o material didático. Essa medidas envolvem atingir a proporção de $80 \%$ de professores com mestrado e doutorado no ensino à distância até 2017 , patamar superior à média atual de $60 \%$. $^{223}$

Em certo modo, os termos da decisão correspondem parcialmente à expectativa de que a fusão entre Kroton e Anhanguera fosse submetida a uma averiguação pormenorizada no CADE, consequência de uma postura mais rigorosa do órgão em relação às fusões e aquisições no setor educacional comparativamente ao procedimento adotado nos negócios no varejo. A partir de 2011, nos casos

possuem vantagens em relação à captação de alunos, preços, marketing, catálogo de cursos, capilaridade de instituições, pólos de ensino e outras variáveis que poderiam inibir a capacidade de concorrência de outras instituições." (Cade firma acordo contra monopólio educacional, Consultor Jurídico, 15 Mai. 2014. Disponível em: http://www.conjur.com.br/2014-mai-15/cade-firma-acordoinstituicoes-monopolio-educacional. Acesso em 18 Mai. 2014.

${ }^{222}$ Cade aplica conjunto de restrições à união de Kroton e Anhanguera, 14 Mai. 2014. Disponível em: http://www.cade.gov.br/Default.aspx?8bbe4fda2aff141feb59ea7cc98a. Acesso em 18 Mai. 2014.

${ }^{223}$ SOUZA, Dayanne. Cade obriga Kroton e Anhanguera a vender ativos e melhorar qualidade. Estácio terá de congelar vagas, $O$ Estado de São Paulo, 15 Mai. 2014. Disponível em: http://economia.estadao.com.br/noticias/geral,cade-obriga-kroton-e-anhanguera-a-vender-ativos-emelhorar-qualidade-estacio-tera-de-congelar-vagas-imp-,1166898. Acesso em 18 Mai. 2014. 
envolvendo o setor educacional, o CADE passou a analisar a concorrência a partir de raios de alcance de alunos, deixando de lado o parâmetro do Estado onde as instituições de ensino se encontravam para verificar como estas competiam. Isso passou a ser analisado bairro a bairro, considerando a possibilidade dos estudantes se deslocarem dentro de uma mesma cidade. Por outro lado, os aspectos societários do negócio - controle e participação - se tornaram objeto de maior atenção dos conselheiros do CADE, dado o desenvolvimento das cadeias societárias e a pulverização dos centros decisórios. A preocupação é de identificar a existência ou não de participações prévias de controladores ou de dirigentes das duas companhias com outros grupos, de modo que o órgão possa saber quem de fato está competindo com quem. ${ }^{224}$ No caso Kroton-Anhanguera, em particular, o CADE não só colocou medidas para o controle da qualidade de ensino, como também alterou a sua postura em relação à forma de análise do mercado relevante de ensino à distância. Enquanto as companhias defendiam apenas a análise local, a conselheira relatora Ana Frazão determinou que o mercado fosse avaliado tanto no plano local como no nacional, na medida em que a escolha do curso pelo estudante não dependeria somente da existência de um polo de ensino próximo a sua residência. ${ }^{225}$

\footnotetext{
${ }^{224}$ BASILE, Juliano. Cade vai passar um pente-fino na fusão, Valor Econômico, 23 Abr. 2013. Disponível em: http://www.valor.com.br/empresas/3096402/cade-vai-passar-um-pente-fino-na-fusao. Acesso em 21 Out. 2013.

${ }^{225}$ SOUZA, Dayanne. Relatora impõe restrições na fusão Kroton e Anhanguera, O Estado de São Paulo, 14 Mai. 2014. Disponível em: http://economia.estadao.com.br/noticias/negocios,relatora-impoerestricoes-na-fusao-kroton-e-anhanguera,184831e. Acesso em 18 Mai. 2014.
} 


\section{EDUCAÇÃO SUPERIOR E REGULAÇÃO DO COMÉRCIO INTERNACIONAL}

A formulação de políticas educacionais excede cada vez mais seus fóruns originais, passando a abranger novos espaços e diferentes atores, nos âmbitos local, nacional e internacional. Políticas como as de concorrência da OMC se insinuam no processo doméstico de formulação das políticas educacionais ou simplesmente, por vezes, justapõe-se a aquelas. ${ }^{226}$

No entanto, os setores educacional e comercial historicamente têm sua própria dinâmica e são mutuamente independentes. Seus representantes raramente tinham negócios em comum e as questões com as quais lidavam, bem como suas esferas de influência, eram muito distantes umas das outras. O mesmo se pode dizer do jargão técnico, com diferentes significados sendo atribuídos as mesmas palavras. A emergência do GATS e o movimento que o acompanha levaram esses atores a interagir, ainda que suas abordagens sigam racionalidades e disciplinas acadêmicas muito distintas. ${ }^{227}$

Ligadas, então, a ordens sociais e institucionais opostas, uma relacionada à comunidade educacional e outra que corresponde à esfera do comércio, de modo geral as duas áreas estão ligadas respectivamente a uma visão crítica sobre os impactos negativos da liberalização comercial e a uma perspectiva positiva sobre os efeitos de acordos internacionais de comércio. No âmbito do debate educacional que se estabelece com o GATS, as críticas provêm de especialistas e acadêmicos, associações de universidades, sindicatos de professores, funcionários da Organização das Nações Unidas para a Educação, a Ciência e a Cultura (UNESCO), e outros provenientes do campo da educação, em um discurso enquadrado pelo compromisso político às funções tradicionais da educação como um bem público e um direito humano. Por sua vez, os apoiadores da liberalização comercial do setor são em sua maioria oriundos do campo do comércio, sobretudo acadêmicos da área, negociadores

\footnotetext{
${ }^{226}$ BALL, Stephen J. Education plc: Understanding private sector participation in public sector education, p. 190.

${ }^{227}$ VERGER, Antoni. Making sense of the GATS debate: semiotic analysis of the conflicting ideas on the education/free-trade relationship, p. 247.
} 
comerciais e funcionários de organizações internacionais voltadas total ou parcialmente a questões relativas ao comércio internacional. ${ }^{228}$

Nesse contexto, independente da confusão entre os efeitos diretos e indiretos das regras multilaterais sobre o comércio de serviços educacionais, faz sentido o emprego da crítica enfática ao chamado modelo liberalizante do GATS. Mesmo que mais flexível do que os demais instrumentos multilaterais e, em especial, do que muitos dos acordos regionais e bilaterais sobre comércio de serviços posteriores a ele, o GATS é um marco ao introduzir a discussão sobre a comercialização da educação superior nos termos do que se discute nesse capítulo. Ao mesmo tempo, traz o desenho básico das regras que buscam regulamentar o comércio de serviços, a divisão dos modos de serviços e dos setores e subsetores educacionais. Assim, o GATS representa um modelo específico de transnacionalização da educação.

Todavia, objeto de poucos compromissos multilaterais de acesso a mercados e tratamento nacional, a abertura do setor educacional é aprofundada no decorrer de um intenso processo de negociações de acordos preferenciais de comércio. A partir do pressuposto de que a educação é um bem comercializável, parte-se em direção a modelos de acordos que se afastam por vezes da liberalização progressiva inerente ao GATS, em um contexto negociador no qual a força dos países em desenvolvimento é diluída e não permite coalizões como as que seriam possíveis na esfera multilateral.

Dessa forma,

"embora algumas atividades permaneçam quase que não tocadas pelas iniciativas de políticas internacionais, e a densidade da regulação internacional varie em diferentes lugares e setores políticos, não há dúvidas de que nós passamos por uma nova forma de governança, cada vez mais internacional e mais técnica."229

\footnotetext{
${ }^{228}$ VERGER, Antoni. Making sense of the GATS debate: semiotic analysis of the conflicting ideas on the education/free-trade relationship, p. 247.

${ }^{229}$ Tradução livre do inglês: "Although there remain activities barely touched by international policy initiatives and the density of international regulation varies in different places and policy sectors, there is no question that we have come to live under a new form of 'governance', at once more international and more technical" (KENNEDY, David. The Politics of the Invisible College: International Governance and the Politics of Expertise, European Human Rights Law Review, n.5, 2001.p. 463).
} 
Ainda que o setor da educação superior no Brasil não seja afetado diretamente pela regulação internacional na matéria, naturalmente sofre as consequências e a influência advindas de uma tecnicização das práticas educacionais mediante vocabulários profissionais de implantação de "melhores práticas" ou valores consensuais, cujo pano de fundo é amiúde a ideia de que a abertura do mercado e a livre concorrência necessariamente ocasionarão em melhores serviços. ${ }^{230} \mathrm{~A}$ governança global é também o trabalho de especialistas e o produto de seu conhecimento técnico (expertise). As ideias de fundo comuns a seus vocabulários profissionais afetam todos que estão envolvidos no processo de formulação de regras internacionais e, por consequência, todos os que são direta ou indiretamente por elas impactados. Tanto a crítica quanto o entusiasmo em relação a essas políticas de cunho liberal subestimam o significado desses profissionais internacionais - advogados internacionalistas, economistas, cientistas políticos - na governança global. ${ }^{231}$

Sendo assim, não deixarão de ser expostas as perspectivas dos autores vinculados à agenda liberal, grande parte deles funcionários da OMC, da OMPI, da OCDE e do Banco Mundial. Suas posições ajudam a entender a estruturação das regras multilaterais sobre o comércio de serviços, e a esclarecer a racionalidade que move as negociações do GATS para os acordos preferenciais de comércio. A manutenção do espaço para as políticas públicas em educação superior no ambiente doméstico, a preservação da educação pública e a garantia da qualidade da educação superior como um todo, hoje envolve necessariamente o conhecimento pelo regulador educacional doméstico do regime de comércio, seus pressupostos, seu modelo de negociações e as medidas tomadas pelos países com os quais o Brasil potencialmente pode se ver envolvido em tratativas multilaterais, regionais e/ou bilaterais.

\footnotetext{
${ }^{230}$ Nesse sentido, por exemplo, Fielden e LaRocque, preocupados em delimitar as "melhores práticas" em políticas educacionais e remover as barreiras comerciais aos investimentos estrangeiros no setor educacional, veem nas organizações internacionais de diversos fins - em especial o Banco Mundial e a Corporação Financeira Internacional - o papel vital de promover uma educação privada de qualidade sob uma agenda eminentemente liberal, auxiliando os países a voltarem suas políticas e canalizando recursos para o setor educacional privado, ao mesmo tempo em que ajudam o mesmo a se promover como um alvo para investimentos (The Evolving Regulatory Context for Private Education in Emerging Economies, p. 5).

${ }^{231}$ KENNEDY, David. The Politics of the Invisible College: International Governance and the Politics of Expertise, p. 466.
} 


\subsection{Natureza da educação superior: de bem público e direito humano a sua inserção em uma lógica comercial}

A educação superior, com externalidades que vão muito além dos benefícios a serem individualmente desfrutados pelos estudantes, tradicionalmente foi identificada de acordo com os bens coletivos dela decorrentes e com a construção da universidade como um espaço crítico de debate público. Com essas características, o direito à educação não só encontrou guarida nas constituições nacionais, mas também foi objeto de regulação em uma série de tratados internacionais, o que o coloca como um importante ramo do direito internacional dos direitos humanos. A paulatina apropriação por outros organismos internacionais, de cunho comercial, do debate sobre políticas educacionais e a derradeira inclusão da educação como um serviço comercializável no GATS/OMC consolidam a inserção da educação superior em uma dinâmica de comércio. Nesse sentido, o direito à educação compartilha com os demais direitos humanos a necessidade de enfrentar em um regime que não o seu questões decisivas para a sua devida implementação.

São ao menos três as formas de conceber a relação entre direitos humanos e comércio internacional no âmbito do regime de comércio. De imediato, existe o risco de apropriação dos primeiros pelo último, a partir de uma leitura estreita do conceito e conteúdo dos direitos humanos, simplificados como direitos individuais mais imediatos e necessários ao exercício das liberdades de comércio. Uma segunda posição é a de que o regime de comércio não poderia e não deveria incluir o debate sobre os direitos humanos, na medida em que tal discussão seria necessariamente enviesada, e tampouco o mandato da OMC corresponderia aos direitos humanos amplamente concebidos. Entre ambas as posições, surgem tanto os autores que preconizam o debate dos direitos humanos como forma de equilibrar as políticas comerciais com um fim distinto da simples liberalização do comércio, quanto os que veem no mandato original do regime do comércio objetivos essencialmente coletivos que, sequestrados pelo neoliberalismo econômico a partir de 1970, foram resinificados e engajados tão somente na abertura de mercados e garantia de eficiência econômica, marginalizando valores e programas políticos distintos. 


\subsubsection{Natureza da educação superior}

Mais do que um direito humano em si mesmo, o direito à educação é uma condição essencial para o pleno gozo de todos os outros direitos econômicos, sociais e culturais, bem como dos direitos civis e políticos. Nesses termos, as características do direito a desfrutar da educação seriam comuns a todas as formas e níveis educacionais, de modo que o direito à educação seria um direito permanente, mas gradual, exercido durante as sucessivas etapas da vida, em uma perspectiva que posiciona a educação superior como um direito humano, junto à educação primária e secundária. $^{232}$

A natureza da educação superior não permite que a consideremos como um simples resultado, eis que produz tanto bens coletivos (públicos) quanto bens privados, gerando benefícios econômicos públicos, benefícios econômicos privados, benefícios sociais públicos e benefícios sociais privados, com significativas interações entre as quatro categorias. ${ }^{233}$ Entre essas características, a literatura tende a reconhecer duas dimensões fundamentais do papel do ensino superior. A primeira relaciona-se ao desenvolvimento do indivíduo, seu processo de formação, aquisição de competências e aprendizado da cidadania. O ensino superior dota os estudantes de competências de alto nível, potencializando as oportunidades de assegurar bons empregos, bons salários e mobilidade social, enquanto estes por consequência colaboram para o desenvolvimento nacional ${ }^{234}$. A educação pode também facilitar a conscientização e contribuir para o desenvolvimento pessoal e formação da identidade e integridade. ${ }^{235}$

A segunda diz respeito à coletividade, por meio da difusão e do

\footnotetext{
${ }^{232}$ DEVIDAL, Pierrick. Trading Away Human Rights? The GATS and the Right to Education: a legal perspective. Journal for Critical Education Policy Studies, v. 2, n. 2, p. 1-24, 2004, p. 2-6.

${ }^{233}$ PUSSER, Brian. Higher Education, Markets, and the Preservation of the Public Good. In: BRENEMAN, David W.; PUSSER, Brian; TURNER, Sarah E. (edit.). Earnings from Learning: The Rise of For-Profit Universities. Albany: State University of New York Press, 2006, p. 37.

${ }^{234}$ Segundo Halvorsen, no ocidente, a educação tem sido associada com 'progresso', 'civilização' e 'desenvolvimento' pelos últimos dois ou três séculos. Depois da Segunda Guerra Mundial, durante o período de restauração nacional e os processo de independência das colônias, teorias do desenvolvimento proliferaram e a educação, em várias formas, tornou-se um fator importante no 'processo de desenvolvimento' (HALVORSEN, Kate. Notes on the Realization of the Human Right to education, Human Rights Quarterly, vol. 12, n. 3, 1990, p. 343; e GROSBON, Sophie. Le droit à l'enseignement supérieur et la liberalisation international du commerce des services, p. 17).

${ }^{235}$ HALVORSEN, Kate. Notes on the Realization of the Human Right to education, p. 343; e GROSBON, Sophie. Le droit à l'enseignement supérieur et la liberalisation international du commerce des services, p. 17.
} 
fortalecimento de conhecimentos que auxiliem a formação de jovens responsáveis. ${ }^{236}$ O ensino superior transmite também valores fundamentais necessários ao exercício da cidadania e da democracia, oferecendo as ferramentas de razão e análise essenciais à participação ativa no debate democrático e dentro das respectivas comunidades. ${ }^{237}$ Assim, diferente de uma simples mercadoria, que pode ser bem definida e singular na forma como se efetiva o seu consumo, os benefícios da educação não são passíveis de avaliação a curto prazo, pois oferecem benefícios à sociedade que vão além dos ganhos direcionados tão só ao estudante. ${ }^{238}$

Diferentes leituras teóricas irão levar a distintas percepções sobre o papel da educação. As teorias do capital humano, por exemplo, tentam provar que a educação, como investimento em capital humano, promoverão crescimento econômico. Assim, postulam a necessidade de técnicos e especialistas profissionais em sociedades capitalistas. Não por acaso, agências governamentais, fundações privadas e organizações internacionais como o Banco Mundial e o FMI estiveram ativamente envolvidas na ideia de investir em capital humano. ${ }^{239}$ Era corrente uma forte crença de que o investimento em educação e treinamento, em um processo de socialização rumo a uma sociedade técnica capitalista, levaria ao crescimento econômico e ao progresso, especialmente nos países em desenvolvimento. ${ }^{240}$

Ainda que a educação superior seja um desafio para todos os países, ela se coloca em grau e escala completamente variáveis de acordo com o estágio e o modo de desenvolvimento de cada estado. Seu papel também está associado a própria

\footnotetext{
${ }^{236}$ GROSBON, Sophie. Le droit à l'enseignement supérieur et la liberalisation international $d u$ commerce des services, p. 17.

${ }^{237}$ GROSBON, Sophie. Le droit à l'enseignement supérieur et la liberalisation international $d u$ commerce des services, p. 17.

${ }^{238}$ BRENEMAN, David W.; PUSSER, Brian; TURNER, Sarah E. The Contemporary Provision of For-Profit Higher Education: Mapping the Competitive Market. In: BRENEMAN, David W.; PUSSER, Brian; TURNER, Sarah E. (edit.). Earnings from Learning: The Rise of For-Profit Universities. Albany: State University of New York Press, 2006, p. 4; OLIVERIO, Cecília Kaneto. O direito ao desenvolvimento e o comércio internacional de serviços educacionais. Faculdade de Direito da Universidade de São Paulo (Dissertação de Mestrado). São Paulo, 2009, p. 113.

${ }^{239} \mathrm{Na}$ definição da importância econômica do setor educacional, o Conselho sobre Comércio de Serviços da OMC destaca o papel crucial da educação na promoção do crescimento econômico, e desenvolvimento pessoal e social, assim como na redução da desigualdade. A educação permitiria aos países enfrentar os desafios das mudanças tecnológicas e da integração comercial global. Através da sua capacidade de prover habilidades e permitir a participação efetiva na força de trabalho, a educação seria crucial para o ajuste econômico (ORGANIZAÇÃO MUNDIAL DO COMÉRCIO. Conselho sobre Comércio de Serviços. Education services: background Note by the Secretariat. 23 Set. 1998 (S/CSS/W/59), p. 2)

${ }^{240}$ HALVORSEN, Kate. Notes on the Realization of the Human Right to education, p. 343.
} 
história e aos avanços de seus sistemas educacionais. ${ }^{241}$ Sobretudo em contextos semelhantes ao brasileiro, deve-se garantir que o ensino superior atue também como uma ferramenta para o desenvolvimento do país como um todo, ${ }^{242}$ sem ignorar os diferentes níveis de desigualdade que se apresentam. Isso não será alcançado por meio de um modelo favorável a uma cultura que despreza o dissenso e fortalece a imersão acrítica na sociedade civil e no mercado. ${ }^{243}$

A criação e preservação das instituições de ensino superior como esferas públicas têm sido instrumental para a formação de um espaço público crítico e de movimentos sociais ao longo do século XX. "A universidade serviu como um lugar para a construção do discurso, símbolos, e atividade política pública em busca do engajamento critico, em vez do bem privado ou autoridade do Estado"244. Em muitos desses momentos foi a interação da universidade como um local de história, cultura e importância simbólica na ampla economia política, com atores de dentro e fora das fronteiras físicas dos campus, que deu energia crítica às lutas políticas. ${ }^{245}$ Essa expectativa de uma "taxa social de retorno" que exceda amplamente o ganho privado é, em geral, uma das motivações mais decisivas para que se mantenham os subsídios ao ensino superior. ${ }^{246}$

Em sentido contrário, sob um contexto de inversão do "público" para o "privado", Klaus Beiter ${ }^{247}$ atesta a tendência emergente de definir educação não mais como um direito humano, mas de chamá-lo de "necessidade humana". O resultado do rebaixamento de "direito" à "necessidade" seria tornar a educação uma mercadoria

\footnotetext{
${ }^{241}$ SGUISSARDI, Valdemar. O desafio da educação superior no Brasil: quais são as perspectivas. In: SGUISSARDI, Valdemar (org.). Educação superior: velhos e novos desafios. São Paulo: Xamã, 2000a, p. 12.

${ }^{242}$ CATANI, Afrânio Mendes; OLIVEIRA, João Ferreira de. A educação superior. In: OLIVEIRA, Romualdo Portela de; ADRIÃO, Theresa (orgs.). Organização do ensino no Brasil: Níveis e modalidades na Constituição Federal e na LDB. São Paulo: Xamã, 2002, p. 88.

${ }^{243}$ SILVA JR, João dos Reis; SGUISSARDI, Valdemar. A educação superior privada no Brasil: novos traços de identidade. In: SGUISSARDI, Valdemar (org.). Educação superior: velhos e novos desafios. São Paulo: Xamã, 2000, p. 165.

${ }^{244}$ Tradução direta do inglês: [...] "the university served as a site for the construction of discourse, symbols, and public political activity in pursuit of critical engagement, rather than private good or state authority." (PUSSER, Brian. Reconsidering Higher Education and the Public Good: The Role of Public Spheres. In: TIERNEY, William G. (edit.). Governance and the Public Good. Albany: State University of New York Press, 2006, p. 19).

${ }^{245}$ PUSSER, Brian. Reconsidering Higher Education and the Public Good: The Role of Public Spheres, p. 19-27.

${ }^{246}$ BRENEMAN, David W.; PUSSER, Brian; TURNER, Sarah E. The Contemporary Provision of For-Profit Higher Education: Mapping the Competitive Market, p. 16.

${ }^{247}$ BEITER, Klaus Dieter. The Protection of the Right to Education by International Law. Leiden, The Netherlands: Martinus Nijhoff Publishers, 2006, p. 2.
} 
que pode ser comercializada sob um preço determinado. Aqueles que não podem pagar o valor seriam excluídos da educação ou, na melhor das hipóteses, receberiam educação de baixa qualidade. A mesma relação é estabelecida por Tristan McDowan $^{248}$ quando discute os protestos em torno das recentes reformas na educação superior no Reino Unido ${ }^{249}$, sustentadas na questão central de saber se o acesso à universidade é um direito ou um privilégio. Ainda que por vezes reduzidas à modificação do montante cobrado por matrículas, as reformas trariam implicações mais profundas, reconfigurando a educação superior como um bem privado que conduz a um retorno econômico, cujo custo deve ser plenamente suportado pelos indivíduos.

O documento sobre serviços educacionais preparado pelo secretariado da OMC estabelece uma relação onde não há referência à educação como "direito" e, de outro lado, é incluído o termo "consumo". Assim, a educação superior poderia ser definida como de "consumo geral" (public consumption), prestada gratuitamente ou com preços que não refletem os custos de produção, ou como um item de "consumo privado" (private comsumption), com preço livremente determinado pelas instituições que a forneçam. ${ }^{250}$

Nesses termos, o processo de transnacionalização paulatinamente é convertido em característica inerente da educação superior. Com um lugar cada vez maior de destaque no âmbito das transformações que se impõem em todas as esferas sociais, "o conhecimento tem reafirmado seu valor como objeto de disputa no mercado" 251. Marco Antônio Dias, ao comentar o referido documento da OMC, critica a tese nele defendida de que, quando se permite a existência de prestadores privados na educação, os governos aceitariam o princípio de que a educação, sobretudo a educação superior, possa ser tratada como um serviço comercializável e,

\footnotetext{
${ }^{248}$ McDOWAN, Tristan. Is There A Universal Right To Higher Education? British Journal of Educational Studies, v.60, n.2, 2012, p. 111.

${ }^{249}$ No contexto regulatório do Reino Unido são indicados objetivos, mas permite-se às instituições encontrar suas próprias formas de alcança-los. Enquanto essas reformas oferecem maior autonomia para estabelecer ou fechar faculdades ou departamentos, ou para desenvolver estruturas e programas interdisciplinares, incluem, de outro lado, redução de fundos governamentais, maior concorrência, e reformas institucionais para cortar custos e aumentar receitas, o que resulta em um esforço para atrair mais estudantes que paguem matrículas, especialmente estrangeiros (OMC, 1998, p. 5).

${ }^{250}$ ORGANIZAÇÃ̃ MUNDIAL DO COMÉRCIO. Conselho sobre Comércio de Serviços. Education services: background Note by the Secretariat, p. 3 .

${ }^{251}$ AGUIAR, Márcia Ângela. Sistemas Universitários na América Latina e as Orientações Políticas de Agências Internacionais. In: CATANI, Afrânio Mendes (org.). Novas Perspectivas nas Políticas de Educaçao Superior na América Latina no Limiar do Século XXI. Campinas, SP: Editora Autores Associados, 1998, p. 103.
} 
assim, passível de ser regulamentado no âmbito da organização. ${ }^{252}$

Em um cenário assim constituído, a busca por lucros é o motor dos projetos de transnacionalização do setor privado com fins lucrativos, e mesmo de algumas universidades tradicionais sem fins lucrativos com problemas financeiros. A centralidade concedida contemporaneamente ao livre comércio estimula a mobilidade internacional da educação, fazendo emergir o risco de naturalização da ideia da educação superior internacional como uma mercadoria a ser comercializada livremente, vista como um bem privado, e não uma responsabilidade pública. ${ }^{253}$

Grande parte da preocupação acerca do crescimento da educação com fins lucrativos reflete um debate histórico sobre os riscos associados à provisão privada de um bem público essencial. ${ }^{254}$ A mundialização da agenda, com a abertura de mercados permeáveis à entrada de grupos internacionais, incorpora no sistema educacional valores e procedimentos, lastreados sobretudo no princípio fundamental da ideologia de mercado, de que a concorrência conduz por si só à eficiência, ganhos de produtividade e economia de custos. ${ }^{255}$ Todavia, uma questão central é definir se a concorrência promove eficiência produtiva ou ganhos privados aos mínimos custos no setor educacional. A ideia do ganho em eficiência associado à entrada de novos fornecedores pode não ser apropriada quando o "produto" educação é de difícil observação e abrange tanto ganhos coletivos quanto recompensas individuais. ${ }^{256}$

Sem regulação adequada, a concorrência comercial gera uma produção estritamente ligada à demanda, quando há estimativa de que essa demanda conduza a lucros ou outro tipo de benefício. Sob tal prisma, na ausência de demanda, o espaço para a produção se tornaria mínimo, e o fornecedor, no caso a instituição de ensino superior, seria, em tese, indiferente aos bens públicos. ${ }^{257}$ Ademais, a demanda deve estar em sintonia com as necessidades mais imediatas dos grandes grupos econômico-

\footnotetext{
${ }^{252}$ DIAS, Marco Antonio Rodrigues. Comercialização no ensino superior: é possível manter a idéia de bem público? Educação e Sociedade, v. 24, n. 84, 2003, p. 822.

${ }^{253}$ ALTBACH, Philip G.; KNIGHT, Jane. The Internationalization of Higher Education: Motivations and Realities. Journal of Studies in International Education, v. 11, n. 3/4, 2007, p. 291-292.

${ }^{254}$ BRENEMAN, David W.; PUSSER, Brian; TURNER, Sarah E. The Contemporary Provision of For-Profit Higher Education: Mapping the Competitive Market, p. 15.

${ }^{255}$ OLIVEIRA, Romualdo Portela de. Reformas educativas no Brasil na década de 90, p. 77; e PUSSER, Brian. Higher Education, Markets, and the Preservation of the Public Good, p. 29.

${ }^{256}$ BRENEMAN, David W.; PUSSER, Brian; TURNER, Sarah E. The Contemporary Provision of For-Profit Higher Education: Mapping the Competitive Market, p. 16.

${ }^{257}$ MARGINSON, Simon. Markets in education. St. Leonards, N.S.W.: Allen \& Unwin, 1997, p. 27.
} 
financeiros. ${ }^{258}$ Tal processo de mercantilização competitiva da educação superior, ${ }^{259}$ com o adensamento das características mercantis e competitivas do setor, leva a uma aproximação da identidade das instituições de ensino superior ao modelo das empresas prestadores de serviços.

Imaginar que a provisão do ensino superior pelo mercado preservaria o papel da educação superior como um bem público desafia uma série de crenças tradicionais sobre a natureza da própria educação. Nesse sentido, John McMurtry ${ }^{260}$ considera que os princípios definidores da educação e os princípios mercadológicos são fundamentalmente contraditórios quanto: a) aos seus objetivos; b) as suas motivações; c) aos seus métodos; e d) aos seus padrões de excelência. Daí resultaria que tentar entender um campo pelos princípios de outro, como cada vez mais tem ocorrido na aplicação do modelo de mercado ao processo educacional, seria inadequado.

\subsubsection{Direito à educação no direito internacional dos direitos humanos}

A educação mereceu status de direito humano em muitas constituições nacionais e obteve o reconhecimento como direito humano na esfera internacional. Acordos internacionais que protegem a educação como um direito humano, ou seja, o direito à educação, foram elaborados em organizações internacionais, principalmente na Organização das Nações Unidas (ONU) e na UNESCO, além de organizações regionais. ${ }^{261}$ Pode-se apontar, assim, a existência de um direito internacional da educação, como um ramo do direito internacional dos direitos humanos, com origens,

\footnotetext{
${ }^{258}$ AGUIAR, Márcia Ângela. Sistemas Universitários na América Latina e as Orientações Políticas de Agências Internacionais, p. 111.

${ }^{259}$ SGUISSARDI, Valdemar. Diferenciação e diversificação: marcas das políticas de educação superior no final do século. In: SGUISSARDI, Valdemar (org.). Educação superior: velhos e novos desafios. São Paulo: Xamã, 2000, p. 60.

${ }^{260}$ McMURTRY, John. Education and the market model. Journal of Philosophy of Education, v. 25, n. 2, 1991, p. 216.

${ }^{261}$ TRAPERO-BALLESTERO, Angel. Le Droit à l'Éducation et le Droit International. In: DUPUY, René Jean. L'Avenir Du Droit International Dans Un Monde Multiculturel. La Haye: Martinus Nijhoff Publishers, 1984, p. 391-400.
} 
fontes normativas, mecanismos de proteção, jurisprudência, doutrina e conteúdo definidos $^{262}$.

O direito à educação encontra sua base normativa em uma variedade de instrumentos internacionais, que podem ser divididos em duas categorias amplas: aqueles que tem força vinculante no direito internacional, como convenções e tratados; e aqueles sem tal força vinculante, como recomendações e declarações. ${ }^{263}$ Isso conduz parte da literatura a sustentar que o direito internacional da educação seria uma disciplina com uma base de hard law, desenvolvido por uma abundante soft $l a w^{264}$. No que diz respeito a sua institucionalidade, que precede os principais acordos internacionais sobre direitos humanos, foi criado um escritório internacional de educação, na Haia, em 1925, como primeiro organismo internacional a tratar especificamente da educação; inicialmente uma instituição privada, em 1929 foi aberto à participação dos Estados, tornando-se, então, a primeira organização internacional intergovernamental no campo da educação, até finalmente, em 1969, passar a fazer parte da UNESCO. ${ }^{265}$

Todavia, somente a Declaração Universal dos Direitos Humanos, de 1948, veio a dar um poderoso impulso para o desenvolvimento da normatividade internacional na área da educação. Mais do que um ponto de chegada, representou um ponto de partida para o direito internacional da educação. ${ }^{266}$ Dentre os direitos positivados pelo então nascente regime de proteção dos direitos humanos, encontra-se o direito à educação. A DUDH, em seu artigo XXVI, trata do ensino elementar, fundamental, técnico-profissional e superior. Orienta a educação "no sentido do pleno desenvolvimento da personalidade humana e do fortalecimento do respeito pelos direitos humanos e pelas liberdades fundamentais" ${ }^{267}$. O artigo 13 do Pacto Internacional sobre Direitos Econômicos, Sociais e Culturais retoma tal enunciado, buscando assegurar a obrigatoriedade e acessibilidade à educação primária, e a

\footnotetext{
262 MONTEIRO, Agostinho Reis. Droit international de l'éducation: une discipline nouvelle, International Review of Education, v. 54, 2008, p. 196.

${ }^{263}$ SINGH, Kishore. Right to Education International Legal Obligations, International Journal of Educational Law and Policy, v. 103, n. 1, 2005, p. 103.

${ }^{264}$ Por ex., MONTEIRO, Agostinho Reis. Droit international de l'éducation: une discipline nouvelle, $\mathrm{p}$. 206.

${ }^{265}$ MONTEIRO, Agostinho Reis. Droit international de l'éducation: une discipline nouvelle, p. 196197.

${ }^{266}$ MONTEIRO, Agostinho Reis. Droit international de l'éducation: une discipline nouvelle, p. 197.

267 Declaração Universal dos Direitos Humanos. Disponível em: http://portal.mj.gov.br/sedh/ct/legis_intern/ddh_bib_inter_universal.htm.
} 
acessibilidade à educação secundária e superior. Segundo o dispositivo, o objetivo de assegurar o pleno exercício desse direito passa igualmente pela implementação progressiva do ensino público. ${ }^{268}$

Enquanto a DUDH apresenta o direito à educação, a Convenção vai além e estabelece a responsabilidade do Estado como o ator principal na implementação deste direito, sob o critério da não-discriminação e da igualdade entre gênero, raça, etnia e religião. No entanto, o caráter universal desses textos determina a generalidade de suas formulações, deixando espaço para interpretações diferentes do que seja educação, de quais são os tipos de educação aí incluídos, quais são as possibilidades e limitações desse direito, e quais os problemas relacionados com o processo de implementação ${ }^{269}$. O direito internacional não prescreve um conceito específico, sobretudo por sua visão necessariamente pluralista, eis que o conteúdo da educação sem dúvida pode variar entre os diferentes tipos de sociedade. Ainda que a educação deva envolver o ganho de conhecimento e habilidades, não há consenso no plano internacional sobre quais conhecimentos e habilidades específicos devam ser adquiridos. $^{270}$

De todo o modo, é o quadro da UNESCO, a agência especializada das Nações Unidas mais preocupada com o direito à educação, a fonte mais abundante da normatividade deste direito. A Convenção contra a Discriminação na Educação, de $1960^{271}$, foi o primeiro, e ainda é o principal tratado sobre o direito à educação. ${ }^{272} \mathrm{~A}$ Convenção de 1960 desenvolve os princípios fundamentais de não-discriminação e igualdade de oportunidades educacionais nas normas internacionais. Em virtude do artigo $4^{\circ}$ da Convenção, os Estados Partes têm a obrigação de formular, desenvolver e aplicar uma política nacional que, pelos métodos apropriados às circunstâncias e aos costumes nacionais, tenda a promover a igualdade de oportunidade e de tratamento em matéria de educação e, em particular, a fazer com que a educação superior seja acessível igualitariamente a todos em função de suas aptidões.

\footnotetext{
268 Pacto Internacional sobre Direitos Econômicos, Sociais e Culturais. Disponível em: http://portal.mj.gov.br/sedh/ct/legis_intern/pacto_dir_economicos.htm.

${ }^{269}$ HALVORSEN, Kate. Notes on the Realization of the Human Right to education, p. 342.

${ }^{270}$ BEITER, Klaus Dieter. The Protection of the Right to Education by International Law, p. 20.

${ }^{271}$ Convenção relativa à Luta contra a Discriminação no campo do Ensino. Disponível em: http://portal.mj.gov.br/sedh/ct/legis intern/conv discriminacao ensino.htm.

${ }^{272}$ MONTEIRO, Agostinho Reis. Droit international de l'éducation: une discipline nouvelle, 197-201.
} 
Entre outras, a Recomendação relativa à condição do pessoal docente da educação superior ${ }^{273}$, de 1997, adotada pela Conferência Geral da UNESCO, em novembro de 1997, contém também disposições referentes às obrigações e responsabilidades das instituições, e aos direitos e liberdades dos docentes. Em seu conceito, a Recomendação determina que a educação superior deva ser direcionada ao desenvolvimento humano e ao progresso da sociedade, cujo financiamento seria um investimento publico. ${ }^{274}$

Este ramo do direito internacional considera a educação como um direito humano, o que implica o dever do Estado de garantir o acesso de todos à educação gratuita, ou a um preço acessível e de qualidade. Para muitos, o descumprimento dessas obrigações constituiria uma violação dos direitos humanos, ensejando a responsabilidade do Estado e a sua obrigação de compensar as vítimas e/ou garantir que a falha não se repita ${ }^{275}$. Nessa perspectiva, ao ratificarem acordos internacionais nos quais o direito à educação é protegido, os Estados partes assumem compromissos na esfera do direito internacional.

Por outro lado, contudo, a globalização revitaliza o papel das agências internacionais no desenho das políticas educacionais. Entre elas, há organizações internacionais com um mandato educacional implícito, como o Banco Mundial e a OCDE, que antes não desempenhavam papel central no tema. Nessas organizações raramente a educação é tratada como um tópico em si: ela é antes concebida como um recurso para lidar com outros tópicos, ficando subordinada a outras agendas. ${ }^{276} \mathrm{O}$ mesmo movimento traz novos atores internacionais para o processo de formulação de políticas na área, principalmente não-governamentais, entre eles corporações transnacionais e fundações, consultores internacionais, coalizões de advocacy transnacionais e comunidades epistêmicas. O papel renovado desses atores na política educacional contribui para a desterritorialização das políticas educacionais, com a redefinição da escala, do espaço e da dinâmica por meio dos quais essas políticas têm sido negociadas, formuladas e implementadas. Os atores internacionais não só

\footnotetext{
${ }^{273}$ Recomendação relativa à condição do pessoal docente do ensino superior. UNESCO, Novembro de 1997. Disponível em: www.cpihts.com/PDF02/Recomendacao\%20UNESCO.pdf.

${ }^{274}$ SINGH, Kishore. Right to Education International Legal Obligations, p. 106.

${ }^{275}$ Por ex., BEITER, Klaus Dieter. The Protection of the Right to Education by International Law, p. 23.

${ }^{276}$ VERGER, Antoni. The Merchants of Education: Global Politics and the Uneven Education Liberalization Process within the WTO, 2009, p. 4. Disponível em: http://educationanddevelopment.files.wordpress.com/2008/04/verger_gats-cer.pdf.
} 
potencializam sua capacidade de estabelecer agendas educacionais e definir as prioridades de países nas reforma da educação, mas também podem impor certas políticas por meio de mecanismos de financiamento e condicionalidades. ${ }^{277}$

Com o advento do GATS, a capacidade de ingerência do comércio internacional na matéria foi ampliada. Diferentes órgãos da ONU tornaram pública sua preocupação em relação ao Acordo. O Alto Comissariado para Direitos Humanos da ONU, em 2003, identificou os setores da saúde (serviços de saúde), educacional (direito à educação) e de serviços ambientais como setores de serviços relevantes ao gozo de direitos econômicos, sociais e culturais, potencialmente incompatíveis com algumas políticas decorrentes do GATS. ${ }^{278}$ No campo da educação, as críticas ao GATS foram canalizadas por meio da UNESCO, com frequentes manifestações de preocupação quanto à perspectiva de comercialização trazida pelo Acordo. Porém, com um orçamento bastante limitado, a organização se encontra à sombra do Banco Mundial, que desfruta de grande influência nas iniciativas de cooperação educacional nos países do Sul; e da OCDE, principal fórum educacional nos países desenvolvidos, tendência que se aprofundou com o GATS, ainda que a UNESCO venha promovendo desde então iniciativas para construir uma posição comum contra as eventuais imposições da OMC no campo da educação e da cultura ${ }^{279}$.

\subsubsection{Direitos humanos e comércio internacional}

Novas circunstâncias redimensionaram, nos últimos anos, o debate sobre a relação entre direitos humanos e comércio internacional. Com a OMC, a regulamentação do comércio expandiu-se para as áreas de propriedade intelectual e serviços, e o sistema de solução de controvérsias foi reforçado, permitindo recursos e sanções comerciais em caso de violação do direito da organização. Ao mesmo tempo,

\footnotetext{
${ }^{277}$ VERGER, Antoni; NOVELLI, Mario; ALTINYELKEN, Hülya Kosar. Global Education Policy and International Development: An Introductory Framework. In: VERGER, Antoni; NOVELLI, Mario; ALTINYELKEN, Hülya Kosar (edit.). Global Education Policy and International Development: New Agendas, Issues and Policies. London and New York: Bloomsbury, 2012, p. 6.

${ }^{278}$ ORGANIZAÇÃO DAS NAÇÕES UNIDAS. Conselho Econômico e Social. Liberalization of trade in services and human rights. Report of the High Commissioner on Human Rights (E/CN.4/Sub.2/2002/9), 2002, p. $12 . \quad$ Disponível em: www.ohchr.org/EN/Issues/Globalization/Pages/ReportsHC.aspx.

${ }^{279}$ VERGER, Antoni; BONAL, Xavier. Against GATS: the Sense of a Global Struggle, Journal for Critical Educational Policy Studies, v.4, n.1, 2006, p. 7.
} 
novos problemas sociais em escala global emergiram. ${ }^{280}$ Esse cenário trouxe consigo o temor de que, amparado por seu mecanismo de enforcement, a OMC eleve o livre comércio sobre e além da proteção e promoção dos direitos humanos. Afora as consequências indiretas do livre comércio, a principal forma pela qual as novas regras comerciais dificultam o gozo dos direitos humanos se dá através da limitação do “espaço político" (policy space) dos Estados, ou seja, de sua capacidade de tomar as medidas necessárias para proteger os direitos humanos. Tal risco evidencia-se, por exemplo, na natureza vinculante dos compromissos assumidos pelos países na liberalização do comércio por meio do GATS, ${ }^{281}$ com limitações que podem ir além das relações mais gerais entre, por exemplo, comércio e meio ambiente; comércio e trabalho; ou comércio e cultura, impactando capacidades regulatórias domésticas que dizem respeito a funções básicas do Estado, como a prestação de educação e saúde à população.

A crescente interdependência entre Estados faz com que a separação entre os dois campos, direito internacional dos direitos humanos e direito do comércio internacional, pareça artificial. ${ }^{282}$ Ainda que as instituições possam ser configuradas de formas distintas, e operar lado a lado mantendo sua identidade, os problemas do cotidiano não respeitam fronteiras jurisdicionais, e a legislação de diferentes instituições necessariamente afeta outros campos de regulamentação. ${ }^{283}$ Há igualmente problemas conceituais, de como uma área compreende a outra, e mesmo de apropriação da primeira pela última. Nesse sentido, Philip Alston ${ }^{284}$, respondendo à proposta de Ernst-Ulrich Petersmann ${ }^{285}$ de integrar os direitos humanos ao direito das organizações internacionais - entre elas a OMC -, pondera que, a despeito da constante invocação do discurso dos direitos humanos, na melhor das hipóteses a

\footnotetext{
${ }^{280}$ COTTIER, Thomas; PAUWELYN, Joost; BURGI, Elisabeth. Linking Trade Regulation and Human Rights in International Law: An Overview. In: COTTIER, Thomas; PAUWELYN, Joost; BURGI, Elisabeth (edit.). Human Rights and International Trade. New York: Oxford University Press, 2005, p. 2 .

${ }^{281}$ DOMMEN, Caroline. Human Rights and Trade: Two Practical Suggestions for Promoting Coordination and Coherence. In: COTTIER, Thomas; PAUWELYN, Joost; BURGI, Elisabeth (edit.). Human Rights and International Trade. New York: Oxford University Press, 2005, p. 200.

${ }^{282}$ COTTIER, Thomas; PAUWELYN, Joost; BURGI, Elisabeth. Linking Trade Regulation and Human Rights in International Law: An Overview, p. 2.

${ }^{283}$ COTTIER, Thomas; PAUWELYN, Joost; BURGI, Elisabeth. Linking Trade Regulation and Human Rights in International Law: An Overview, p. 2.

${ }^{284}$ ALSTON, Philip. Resisting the Merger and Acquisition of Human Rights by Trade Law: A Reply to Petersmann, European Journal of International Law, v.13, n.4, 2002, p. 816.

${ }^{285}$ PETERSMANN, Ernst-Ulrich. Time for a United Nations 'Global Compact' for Integrating Human Rights into the Law of Worldwide Organizations: Lessons from European Integration, European Journal of International Law, v. 13, n. 3, p. 621-650, 2002.
} 
abordagem proposta seria dificilmente conciliável com o direito internacional dos direitos humanos, e na pior das hipóteses o minaria drasticamente. Em suma, o resultado de seguir tal caminho seria o sequestro do direito internacional dos direitos humanos, com a redefinição de seus contornos e sua sujeição ao princípio da liberalização.

Ainda que Petersmann não delimite precisamente o que entende por direitos humanos, sua alegação básica é de que o direito do comércio internacional deve partir de uma abordagem de direitos humanos, e reconhecer, como o faria a Corte Europeia de Direitos Humanos, o princípio da livre circulação de bens e da livre concorrência como um direito fundamental. ${ }^{286} \mathrm{O}$ núcleo comum do mercado e dos direitos humanos seria o respeito pela autonomia pessoal e diversidade individual. Ambos teriam sido projetados para proteger as preferências individuais e promover o autodesenvolvimento pessoal baseado na cooperação social voluntária, em mecanismos de alocação, coordenação e enforcement, em direitos básicos igualitários e em regras de concorrência não discriminatórias. ${ }^{287} \mathrm{Em}$ tal abordagem, entre os direitos humanos e os mecanismos de mercado, econômicos e políticos, resultantes da proteção dos direitos humanos, estariam a liberdade de informação e a liberdade de imprensa, e os direitos de propriedade e liberdade contratual. Assim, os direitos humanos trariam incentivos para a poupança e investimentos, e protegeriam os direitos individuais de comprar e vender bens e serviços. ${ }^{288}$

Com efeito, para Petersmann, a legitimidade da OMC como um sistema jurídico depende da transformação das liberdades de mercado em direitos fundamentais. ${ }^{289}$ Todavia, as garantias da OMC às quais o autor se refere, de liberdade, não discriminação e direitos de propriedade, não são direitos conferidos aos indivíduos no sentido de direitos humanos. A garantia de algumas liberdades econômicas não pode ser razoavelmente comparada aos direitos humanos em qualquer sentido mais amplo, familiar às tradições do direito internacional dos

\footnotetext{
${ }^{286}$ ALSTON, Philip. Resisting the Merger and Acquisition of Human Rights by Trade Law: A Reply to Petersmann, p. 823-824.

${ }^{287}$ PETERSMANN, Ernst-Ulrich. Human Rights, Markets and Economic Welfare: Constitutional Functions of the Emerging UN Human Rights Constitution. In: ABBOTT, Frederick M.; BREININGKAUFMANN, Christine; COTTIER, Thomas (edit.). International Trade and Human Rights: Foundations and Conceptual Issues. University of Michigan, 2006, p. 37.

${ }^{288}$ PETERSMANN, Ernst-Ulrich. Time for a United Nations 'Global Compact' for Integrating Human Rights into the Law of Worldwide Organizations: Lessons from European Integration, p. 626-627.

${ }^{289}$ HOWSE, Robert. Human Rights in the WTO: Whose Rights, What Humanity, Comment on Petersmann, European Journal of International Law, v.13, n.3, 2002, p. 655.
} 
direitos humanos. ${ }^{290}$ A partir do momento em que define os direitos de liberdade como direitos de propriedade e liberdade contratual, o foco real do seu conceito de direitos humanos é incrivelmente limitado, em uma leitura na qual a OMC nunca seria chamada a promover direitos sociais. ${ }^{291}$ Direitos sociais, econômicos e culturais só poderiam ser perseguidos pelos governos na medida em que eles pudessem ser apresentados como limites "necessários" às liberdades de mercado. ${ }^{292}$

A integração sugerida por Petersmann entre diferentes corpos de direitos humanos ou diferentes direitos, promoveria uma única agenda, com a ênfase nas liberdades necessárias ao funcionamento do mercado. Certamente não é uma resposta à necessidade de uma abordagem conjunta entre o direito internacional dos direitos humanos e o direito do comércio internacional, sobretudo quanto às questões relacionadas aos direitos sociais, econômicos e culturais. Ainda que se discuta o alcance do mandato da OMC, a apropriação de um campo pelo outro dentro da organização parece inevitável se for conduzida nesse sentido.

Em momento anterior à crítica a Petersmann, Robert Howse e Makau Mutua $^{293}$ argumentaram que os regimes de comércio e de direitos humanos não precisam necessariamente estar em conflito, desde que o regime de comércio seja interpretado e aplicado de uma maneira consistente com as obrigações dos Estados em matéria de direitos humanos, que estariam em um patamar hierarquicamente superior, prevalecendo sobre disposições conflitantes de qualquer tratado internacional de outra natureza. Para os autores, o preâmbulo do Acordo da OMC não torna o livre comércio um fim em si mesmo; ao contrário, estabelece os objetivos do sistema como relacionados à realização de valores humanos básicos, incluindo a melhora do padrão de vida para todas as pessoas e o desenvolvimento sustentável. Em sentido diverso, Alston ${ }^{294}$ aponta que o Acordo que estabelece a OMC não é um instrumento constitucional, no sentido de constituir uma comunidade política ou

\footnotetext{
${ }^{290}$ ALSTON, Philip. Resisting the Merger and Acquisition of Human Rights by Trade Law: A Reply to Petersmann, p. 825-826.

${ }^{291}$ ALSTON, Philip. Resisting the Merger and Acquisition of Human Rights by Trade Law: A Reply to Petersmann, p. 827.

${ }^{292}$ HOWSE, Robert. Human Rights in the WTO: Whose Rights, What Humanity, Comment on Petersmann, p. 655.

${ }^{293}$ HOWSE, Robert; MUTUA, Makau. Protecting Human Rights in a Global Economy: Challenges for the WTO. International Centre for Human Rights and Democratic Development, 2000, p. 4. Disponível em: http://www.ichrdd.ca/english/commdoc/publications/globalization/wtoRightsGlob.html.

${ }^{294}$ ALSTON, Philip. Resisting the Merger and Acquisition of Human Rights by Trade Law: A Reply to Petersmann, p. 836.
} 
social, e que seu mandato e objetivos são focados na expansão da produção e comércio de bens e serviços. Mesmo a expansão do mandato original do GATT para áreas como a indústria de serviços e os direitos de propriedade intelectual ainda teria deixado intocada a estrutura básica da organização, dominada por produtores, na qual interesses econômicos, sociais, culturais, políticos de um grande número de pessoas não são, na prática, representados. "Sua estrutura institucional, seus processos e os resultados que sancionam estão longe do que seria necessário de um órgão para o qual uma significativa autoridade em direitos humanos pudesse ser confiada." ${ }^{295}$ No campo específico da educação, se faz eco a essa crítica, no sentido de que o sistema da OMC não teria um mandato educacional particular e, tampouco, impulsionaria uma agenda educacional explícita, estando preocupado basicamente com a promoção do livre comércio global, incluídos aí os serviços educacionais. ${ }^{296}$

Andrew Lang ${ }^{297}$ tenta superar o debate entre comércio e direitos humanos ao propugnar que o real desafio é desfazer a ideia de que a governança comercial compreenderia somente interesses privados, eis que ela concerne igualmente aos interesses coletivos. Assim, os esforços de colaboração e cooperação entre os dois regimes provavelmente falharão em seus objetivos se não forem acompanhados de um repensar dos quadros ideológicos que definem o papel e o fim de cada um deles. Segundo o mesmo autor, as críticas e as propostas de mudança no regime de comércio focam a retirada de restrições excessivas e a abertura de "espaço político" (policy space) suficiente para os membros da OMC, enquanto o regime de comércio seria muito mais do que um conjunto de regras vinculantes. Seria um ambiente social no qual ideias sobre como as melhores e mais apropriadas políticas comerciais são geradas, legitimadas e disseminadas; um ambiente cognitivo no qual os Estados são ensinados a interpretar a ordem econômica internacional, e como calcular seus interesses nela; e seria também um ambiente institucional que reconfigura o conjunto de atores envolvidos na formulação de políticas de comércio, e as vias de influência disponíveis para eles. Essas funções do regime de comércio

\footnotetext{
${ }^{295}$ Tradução direta do inglês: "its institutional structure, its processes and the outcomes it sanctions are far from what would be required of a body to which significant human rights authority could be entrusted." (ALSTON, Philip. Resisting the Merger and Acquisition of Human Rights by Trade Law: A Reply to Petersmann, p. 836).

${ }^{296}$ VERGER, Antoni. The Merchants of Education: Global Politics and the Uneven Education Liberalization Process within the WTO, p. 7.

${ }^{297}$ LANG, Andrew. World Trade Law after neoliberalism: re-imagining the global economic order. New York, Oxford University Press, 2011.
} 
seriam importantes à medida que também afetam os direitos humanos, ao mesmo tempo que representam alguns dos mais significativos mecanismos pelos quais o regime de comércio pode ser engajado na reconstrução de uma ordem econômica internacional diferente e melhor. ${ }^{298}$

Com efeito, para Lang, as leituras sobre as funções e objetivos da OMC subestimam o grau com o que o pensamento neoliberal mudou radicalmente o regime de comércio, eis que a transformação do direito internacional econômico a partir de 1970 teria simplesmente refeito o regime, envolvendo o esquecimento coletivo de compromissos políticos anteriores, e a marginalização das tradições concorrentes de pensamento dentro do regime. Por isso, recusa a ideia de que receitas neoliberais estariam codificadas desde o princípio dentro do direito da OMC. Para o autor, muitos dos conceitos centrais do pensamento liberal econômico sobre o comércio - 'barreira comercial', 'falha de mercado', 'distorção de mercado' e mesmo 'livre comércio' - seriam indeterminados, de forma que o mandato do regime GATT/OMC os tornaria de todo compatíveis com um amplo espectro de diferentes programas políticos. Junto com as mais importantes disciplinas do direito da OMC, que serão apresentadas na sequência desta tese poderiam ser e, segundo Lang, têm sido interpretadas de diferentes formas. ${ }^{299}$

Por tudo isto, ao lidar com conceitos advindos do direito do comércio internacional e do campo educacional, o tema da transnacionalização da educação superior envolve necessariamente um contexto que se convencionou chamar de "virada neoliberal", tanto na esfera internacional quanto na esfera doméstica, com efeitos transversais que redefiniram a natureza da política. Lang assevera que

"o pensamento neoliberal representou um afastamento de uma ideia da política como a criação, mobilização e realização dos objetivos coletivos de uma comunidade política em direção a uma ideia da política como a facilitação da busca dos indivíduos por seus próprios objetivos e fins privados". 300

\footnotetext{
${ }^{298}$ LANG, Andrew. Rethinking Trade and Human Rights. bepress Legal Series, Working Paper 1685, 2006, $\quad$ p. $87 . \quad$ Disponível em: http://law.bepress.com/expresso/eps/1685.

${ }^{299}$ LANG, Andrew. World Trade Law after neoliberalism: re-imagining the global economic order, p. 5.

${ }^{300}$ Tradução direta do ingles: "neoliberal thought represented a turn away from an idea of politics as the creation, mobilization, and realization of the collective purposes of a political community, towards an idea of politics as the facilitation of individuals' pursuit of their own private goals and purposes." (LANG, Andrew. World Trade Law after neoliberalism: re-imagining the global economic order, p. 1)
} 
Aplicada ao próprio regime de comércio, essa ideia mudou a forma como a política do comércio internacional era conduzida, obstruindo a noção de fim coletivo que animou o regime e inspirou a sua formação normativa. Assim, o regime de comércio viu-se como um mercado político, um pouco mais do que um fórum para a troca de concessões comerciais e a promoção por cada Estado de seus interesses exportadores, estritamente definidos. ${ }^{301}$ Em um segundo momento, aplicada às políticas domésticas dos membros da OMC, a ideia neoliberal de política alterou o modo com a intervenção governamental legítima foi diferenciada da intervenção ilegítima, para os fins do direito da organização, tornando mais difícil a intervenção governamental na economia em busca de fins sociais coletivos. ${ }^{302}$

A mercantilização de novas áreas da vida social, a prioridade dada à criação de renda e à eficiência econômica como objetivos políticos primordiais foi desequilibrada e desatenta a valores sociais alternativos, além de ineficaz no que atine a entregar à sociedade o grau de prosperidade material prometido. De todo o modo, o pouco espaço dado no âmbito do regime de comércio aos custos distributivos, ambientais ou sociais da liberalização do comércio internacional advêm sobretudo do fato de estes não serem considerados como tópicos apropriados de debate dentro do limitado escopo da governança econômica internacional, nos termos em que foi redefinida no seio da imaginação neoliberal. ${ }^{303}$

Esta realidade demanda um número maior de estudos que trabalhem de maneira explícita com as consequências substantivas do direito do comércio internacional, traçando as linhas causais das escolhas tomadas no contexto global e as consequências práticas sobre setores específicos. Ao tornar visíveis perspectivas em geral ignoradas no contexto do regime de comércio internacional pode-se diminuir o poder das ideias neoliberais descritas, que procuram tornar essas consequências irrelevantes no processo decisório no nível global, e que naturalizam e legitimam um modo de governança na qual a responsabilidade sobre os seus principais resultados é

\footnotetext{
${ }^{301}$ LANG, Andrew. World Trade Law after neoliberalism: re-imagining the global economic order, p. 6.

${ }^{302}$ LANG, Andrew. World Trade Law after neoliberalism: re-imagining the global economic order, $\mathrm{p}$. 7.

${ }^{303}$ LANG, Andrew. World Trade Law after neoliberalism: re-imagining the global economic order, p. $2-10$.
} 
alocada em outros fóruns. ${ }^{304} \mathrm{~A}$ recalibração das prioridades e dos valores do regime implicaria a efetiva inclusão de questões sociais e de desenvolvimento, artificialmente dissociadas da liberalização comercial, e assim atuaria também no sentido de corrigir ou diminuir o desequilíbrio operacional do sistema em favor dos países em desenvolvimento. ${ }^{305}$

\subsection{Regulamentação multilateral do comércio de serviços sob a perspectiva dos serviços educacionais}

No processo de expansão da regulação internacional do comércio de serviços, que da esfera multilateral se estende ao crescente número de acordos preferenciais de comércio, as negociações em torno dos capítulos de serviços avançam com base no modelo do GATS e no modelo do Tratado Norte-Americano de Livre Comércio (NAFTA). A opção por um deles ou até mesmo a combinação entre suas disposições depende dos parceiros comerciais. Essa escolha e a maneira pela qual os signatários manejam as listas de liberalização determinam a profundidade do acordo e as suas efetivas consequências comerciais.

Independente da liberalização comercial efetivamente alcançada a partir de suas negociações, o GATS, como o primeiro grande acordo multilateral na matéria, estabelece parâmetros que, em maior ou menor medida, são replicados nos acordos preferenciais de comércio assinados na sequência. Assim, além das suas disciplinas específicas, são apresentados a liberalização do comércio de serviços através da lista positiva, a estruturação dos cronogramas de liberalização, os modos de serviços que congregam em quatro categorias as formas pelas quais estes podem ser prestados, e, por fim, a exclusão dos serviços prestados no exercício da autoridade governamental.

\subsubsection{Comércio de serviços: Acordo Geral sobre Comércio de Serviços (GATS)}

\footnotetext{
${ }^{304}$ LANG, Andrew. World Trade Law after neoliberalism: re-imagining the global economic order, p. 352-353.

${ }^{305}$ CELLI JUNIOR, Umberto. Comércio de Serviços na OMC: Liberalização, Condições e Desafios. Curitiba: Juruá, 2009, p. 138.
} 
O GATS é um dos numerosos acordos que foram adotados em 1994 como parte do então recém estabelecido sistema da OMC, e se aplica a todos os membros da organização. Foi resultado de um longo e oneroso processo, incentivado inicialmente pelos Estados Unidos. De um lado, sofria a forte resistência de um grupo de países em desenvolvimento, especialmente Índia e Brasil; de outro, a União Europeia não oferecia grande apoio durante o processo preparatório. Se os Estados Unidos agiam motivados pela força competitiva de seus principais setores de serviços, os países que resistiam ao acordo eram movidos, entre outros fatores, pela preocupação com suas indústrias nascentes, a soberania econômica nacional e o medo de que novos temas pudessem desviar a atenção dos seus próprios interesses comerciais em áreas como têxteis e vestuário. ${ }^{306}$

Trata-se de um acordo ambicioso e complexo, com vários níveis de obrigações, ampliando a abrangência do sistema multilateral de comércio. ${ }^{307} \mathrm{No}$ âmbito do comércio de serviços, procura sobretudo garantir uma certa predicabilidade, contendo obrigações voltadas a garantir que os prestadores de serviços conduzam suas atividades em um ambiente regulatório estável, em que novas barreiras comerciais não sejam erguidas livremente nem velhas barreiras reestabelecidas. ${ }^{308}$

Por consequência, o GATS acaba por representar um modelo específico de transnacionalização da educação. ${ }^{309} \mathrm{O}$ Acordo introduz a discussão sobre a comercialização da educação superior nos termos do que se discute aqui. Ao mesmo tempo, traz o desenho básico das regras que buscam regular o comércio internacional de serviços, entre eles os serviços educacionais, a divisão dos modos por meio dos quais são prestados e dos setores e subsetores desses serviços. É, portanto, um instrumento jurídico chave, provavelmente o mais importante para alcançar esse

\footnotetext{
${ }^{306}$ ADLUNG, Rudolf. Services Trade Liberalization from Developed and Developing Country Perspectives. In: SAUVÉ, Pierre and STERN, Robert M. (edit.). GATS 2000: new directions in services trade liberalization. Washington: The Brookings Institution, 2000, p. 113.

${ }^{307}$ SINCLAIR, Scott. GATS: How the World Trade Organization's new 'services' negotiations threaten democracy, p. 3.

${ }^{308}$ VERGER, Antoni. The constitution of a new global regime: Higher education in the GATS/WTO framework, p. 114.

${ }^{309}$ Em outro sentido, Andrew Lang vê o GATS como um programa ainda aberto, que não impõe projetos particulares de reformas regulatórias em disciplinas regulatórias concretas, legalmente vinculantes para os membros da OMC. Assim, não se poderia falar de prescrições específicas sobre um modelo de regulamentação considerado como ideal. Não só seus efeitos, mas também os conceitos fundamentais por trás dele não teriam seus significados dados a priori. (LANG, Andrew. World Trade Law after neoliberalism: re-imagining the global economic order, p. 283).
} 
objetivo, por ser capaz de determinar a maior parte dos elementos que constituem um regime de comércio, em um processo que fortalece a reestruturação neoliberal das universidades e dá grande peso jurídico a uma série de medidas pró-mercado que, uma vez colocadas em prática, tornam-se, por diferentes razões, muito difíceis de reverter. ${ }^{310}$

De outro lado, sob a perspectiva liberal, tem-se a crítica de que o êxito do acordo como marco regulatório desta matéria encontra um contraponto na limitada liberalização comercial alcançada a partir de então na esfera multilateral, tendo em vista que os principais resultados ficaram circunscritos à consolidação por parte de alguns países dos regimes regulatórios já vigentes em determinados setores. ${ }^{311}$ Nesse sentido, a comercialização da educação, particularmente da educação superior, têm se intensificado de maneira bastante independente do comércio de serviços no âmbito do GATS, como é o caso do Brasil. Seria um equívoco esperar que a Rodada Doha pudesse tanto estancar essa tendência de transnacionalização ou até mesmo acelerar drasticamente o processo. ${ }^{312}$

A maior facilidade encontrada pelos serviços educacionais para liberalização no plano doméstico, ainda que fora do contexto de negociações comerciais internacionais, pode ser explicada pelas particularidades que tornam a regulamentação do comércio de serviços distinta daquela exigida pelo comércio de bens. Primeiramente, a definição de comércio vai além dos fluxos transfronteiriços e abrange mais três modos de fornecimento. ${ }^{313}$ Em segundo lugar, a aplicação das regras sobre serviços não se limita às medidas ligadas a produtos, mas abrange também leis ligadas a produtores e regulações. Seus contratos tendem a especificar a atividade a ser desempenhada, em lugar do produto ou resultado final. Diferente de um contrato de venda de mercadorias, que implica transferência de propriedade da coisa vendida ao comprador, a prestação de serviços é muito mais complexa, tendo em vista sua natureza frequentemente imaterial ou intangível. Por último, não tendo o

\footnotetext{
${ }^{310}$ VERGER, Antoni. The constitution of a new global regime: Higher education in the GATS/WTO framework, p. 112.

${ }^{311}$ HOEKMAN, Bernard. Assessing the General Agreement on Trade in Services. In: MARTIN, Will and WINTERS, Alan L (edit.). The Uruguay Round and the developing countries. Cambridge: University Press, 1996, p. 88.

${ }^{312}$ LIM, Aik Hoe; SANER, Raymond. Rethinking Trade in Education Services: A Wake-Up Call for Trade Negotiators, p. 1028.

${ }^{313}$ ADLUNG, Rudolf; ROY, Martin. Turning hills into mountains? Current commitments under the gats and prospects for change. World Trade Organization (Staff Working Paper ERSD-2005-01), Mar. 2005. Disponível em: http://ssrn.com/abstract=922058, p. 4-5.
} 
foco na proteção tarifária, as regras de serviços envolvem dois conjuntos diferentes de obrigações comerciais negociáveis - "acesso a mercados" e "tratamento nacional" -, ou seja, enfrentam barreiras ao comércio que não tomam a forma de tarifas de importação: trata-se de proibições, restrições quantitativas e regulamentação governamental. ${ }^{314}$ Assim, por exemplo, com o intuito de proteger da concorrência estrangeira os prestadores de serviços locais, os governos adotam medidas de proteção que são inseridas na legislação interna endereçada ao consumo ou ao fornecimento local de serviços. ${ }^{315}$ Por essa razão, o GATS é um instrumento concebido justamente para possibilitar a retirada de qualquer discriminação contra o fornecedor de serviços estrangeiros das legislações domésticas, e modificar regras que restrinjam o ingresso no mercado de prestadores estrangeiros, ainda que sem conteúdo explícito de discriminação. ${ }^{316}$

Obedecendo a tais particularidades, a arquitetura do GATS é composta por uma estrutura de três camadas principais:

- um acordo-quadro geral com regras que se aplicam a todos os serviços;

- compromissos específicos de acesso a mercados e tratamento nacional que se aplicam somente àqueles serviços listados pelos países em seus cronogramas individuais de liberalização no GATS;

- e os anexos que tratam de estabelecer regras para setores particulares, como telecomunicações e serviços financeiros.

Junto a essas partes principais estão incluídos o compromisso global de promover sucessivas rodadas futuras de negociação, a fim de aumentar a cobertura e expandir o acordo, em uma lógica de liberalização progressiva por meio do método da solicitação-oferta ${ }^{317}$; a Parte I, com o alcance e definições do Acordo; as decisões do

\footnotetext{
314 HOEKMAN, Bernard. Assessing the General Agreement on Trade in Services, p. 90; e MARCHETTI, Juan A. Developing Countries in the WTO Services Negotiations. Staff Working Paper ERSD-2004-06, Set. 2004, p. 4.

${ }^{315}$ CELLI JUNIOR, Umberto. Comércio de Serviços na OMC: Liberalização, Condições e Desafios, p. 84.

${ }^{316}$ CELLI JUNIOR, Umberto. Comércio de Serviços na OMC: Liberalização, Condições e Desafios., p. 85.

317 "Segundo esse método, o membro demandante envia um pedido para um ou mais membros solicitando a abertura de um ou mais setores de serviços, bem como a de seus modos de prestação. Em face do pedido inicial, demandante e demandados iniciam consultas de maneira a chegar a um acordo acerca dos setores e subsetores e dos modos de prestação de serviços que cada um deles estaria disposto a liberalizar. Os demandados que tiverem interesse em prosseguir nas negociações poderão, a
} 
Conselho de Comércio para Serviços (CCS) e do Conselho Geral da OMC e as declarações ministeriais relativas a serviços que se somam ao Acordo. ${ }^{318}$

As disposições gerais estão na Parte II do GATS, que contém as obrigações às quais os países se submetem automaticamente ao aderirem à OMC. São previstas, assim, disposições que dão conta, em particular, do tratamento de nação mais favorecida (Artigo II), de transparência (Artigo III), regulação doméstica (Artigo VI), e reconhecimento (Artigo VII), bem como exceções como integração econômica (Artigo V), restrições para proteger a balança de pagamentos (Artigo XII), exceções gerais e exceções de segurança (Artigo XIV). A Parte II do GATS inclui também quatro disposições que estabelecem futuras negociações sobre aspectos nos quais os negociadores da Rodada Uruguai não puderam alcançar consenso: mais disciplinas sobre regulação domésticas (Artigo VI:4), medidas de salvaguarda emergenciais (Artigo X:1), compras governamentais (Artigo XIII:2), e subsídios (Artigo XV:1).

Principal obrigação geral, o tratamento de nação mais favorecida tem como objetivo garantir igualdade de oportunidades para os serviços e prestadores de serviços de todos os Membros da OMC, de forma que privilégios e benefícios concedidos a um Membro sejam imediata e incondicionalmente estendidos aos demais. Para aferir a consistência da medida, três condições devem ser verificadas: primeiro, se a medida em questão é coberta pelo GATS; segundo, se os serviços ou os prestadores de serviços em questão são similares (like); e, por fim, se o Membro da OMC concede tratamento menos favorável aos serviços ou prestadores de serviços de outro Membro ${ }^{319}$. Cumpridos esses requisitos, deveria o Membro que estabeleceu a medida conceder aos demais Membros um tratamento não menos favorável do que aquele concedido a serviços e prestadores de serviços de qualquer outro país. Contudo, o tratamento de nação mais favorecida é também a única obrigação geral no GATS a permitir que os Membros mantenham medidas incompatíveis com o referido tratamento desde que as mesmas se encontrem listadas no anexo sobre isenções ao Artigo II.

seu exclusivo critério, apresentar suas respectivas listas de compromissos" (CELLI JUNIOR, Umberto. Comércio de Serviços na OMC: Liberalização, Condições e Desafios., p. 102).

${ }^{318}$ CELLI JUNIOR, Umberto. Comércio de Serviços na OMC: Liberalização, Condições e Desafios., p. 86 .

${ }^{3} 19$ ORTINO, Federico. Services. In: LESTER, Simon; MERCURIO, Bryan. Bilateral and Regional Trade Agreements: Commentary and Analysis (ed.). New York: Cambridge University Press, 2009, p. 189-190. 
No campo das disposições sobre transparência (Artigo III), as obrigações gerais não trazem grande impacto à autonomia reguladora dos Membros, na medida em que estes não são obrigados a modificar ou a abolir suas normas e regulamentos domésticos. Em boa parte dos países, incluindo o Brasil, já vigoram regras que determinam a publicidade de leis, normas e regulamentos em geral. ${ }^{320}$ De modo geral, estão previstos os deveres de cada Membro publicar prontamente, salvo em circunstâncias emergenciais, todas as medidas relevantes de aplicação geral pertinentes ao GATS ou que afetem sua operação, incluindo acordos internacionais; de informar o CCS da introdução ou modificação de quaisquer novas legislações, regulamentações ou normas administrativas que afetem significativamente o comércio de serviços coberto por seus compromissos específicos; e de responder prontamente aos pedidos de informação específica apresentados por qualquer outro Membro a respeito de medidas de aplicação geral ou acordos internacionais.

Quanto à regulamentação doméstica, o Artigo VI do GATS estabelece alguns padrões de devido processo administrativo, em particular o dever de garantir que todas as medidas de aplicação geral capazes de afetar o comércio de serviços sejam administradas de maneira razoável, objetiva e imparcial (Artigo VI:1), e manter ou instituir "tão logo seja factível, tribunais judiciais, arbitrais ou administrativos ou procedimentos que permitam, após solicitação de um prestador de serviços afetado, a pronta revisão das decisões administrativas que afetem o comércio de serviços e, quando for justificado, a aplicação de recursos apropriados" (Artigo VI:2).

Fica a cargo do CCS o estabelecimento das disciplinas necessárias para assegurar que medidas relativas a requisitos e procedimentos em matéria de qualificação, de normas técnicas e requisitos em matéria de licenças não constituam obstáculos desnecessários ao comércio de serviços. Essas disciplinas deverão assegurar que tais requisitos, "inter alia": a) sejam baseados em critérios objetivos e transparentes, tais como a competência e a habilidade para prestar o serviço; b) não sejam mais gravosos que o necessário para assegurar a qualidade do serviço; c) no caso dos procedimentos em matéria de licença, não constituam em si mesmos uma restrição para a prestação do serviço (Artigo VI:4). Ainda que essa disposição até

\footnotetext{
${ }^{320}$ CELLI JUNIOR, Umberto. Comércio de Serviços na OMC: Liberalização, Condições e Desafios., p. 93.
} 
então só tenha sido aplicada em relação ao setor de contabilidade, ela evidencia que a liberalização de comércio de serviços, mais do que no comércio de bens, requer a adoção de abordagens ad hoc quanto a setores específicos de serviços ${ }^{321}$.

Diferente das obrigações gerais, a Parte III do GATS traz uma série de obrigações que são, a seu turno, dependentes do nível de compromissos assumidos por cada Membro. Assim, em relação às obrigações de acesso a mercados (Artigo XVI) e tratamento nacional (Artigo XVII) vige a abordagem da "lista positiva", por meio da qual as regras somente se estendem aos setores de serviços deliberadamente incluídos pelos Membros em seus cronogramas individuais de compromissos.

Em acesso a mercados, o Artigo XVI identifica, aparentemente de maneira exaustiva ${ }^{322}$, uma série de medidas, em sua maioria de natureza quantitativa, que os Membros não devem manter ou adotar em setores nos quais compromissos específicos tenham sido consolidados, salvo se especificado em contrário nas listas de liberalização apresentadas pelos países. Para fins de aplicação desse dispositivo, independe se tais medidas tenham sido impostas de forma discriminatória ou sobre prestadores e serviços nacionais e prestadores e serviços estrangeiros sem discriminação. Por outro lado, não há obrigação explicita de conceder acesso a mercado, mas sim de assegurar que os Membros garantam aos serviços e aos prestadores de serviços de outros Membros um tratamento não menos favorável do que aquele especificado em sua lista de compromisso. ${ }^{323}$

Salvo determinação em contrário em sua lista, em virtude do Artigo XVI:2, um Membro não poderá manter ou adotar limitações nos setores em que assumiu compromissos de acesso a mercados, quanto ao: (a) número de prestadores de serviços que têm permissão de acesso, independente se na forma de contingentes numéricos, monopólios ou prestadores de serviços exclusivos ou por meio da exigência de prova de necessidade econômica; (b) valor total dos ativos ou das transações de serviços; (c) número total de operações de serviços ou da quantidade total de serviços produzidos; (d) número total de pessoas físicas que possam ser

\footnotetext{
${ }^{321}$ ORTINO, Federico. Services, p. 191.

${ }^{322}$ Todavia, no caso US-Gambling Services, o Painel e o Órgão de Apelação fizeram uma leitura ampla das limitações de acesso a mercados listadas no Artigo XVI, incluindo qualquer medida com efeito similar a qualquer das limitações de acesso a mercados listadas no Artigo XVI:2, independentemente da forma (Ortino, 2009, p. 193).

${ }^{323}$ CELLI JUNIOR, Umberto. Comércio de Serviços na OMC: Liberalização, Condições e Desafios., p. 96.
} 
empregadas em um setor ou que um prestador de serviços possa empregar; (e) tipos específicos de pessoa jurídica ou de empreendimento conjunto (joint venture); e (f) estabelecimento de percentuais específicos de participação do capital estrangeiro ou do valor total dos investimentos estrangeiros.

O Artigo XVII, por sua vez, em relação ao tratamento nacional, exige que cada Membro, nos setores inscritos em sua lista, outorgue "aos serviços e prestadores de serviços de qualquer outro Membro, com respeito a todas as medidas que afetem a prestação de serviços, um tratamento não menos favorável do que aquele que dispensa a seus próprios serviços similares e prestadores de serviços similares". A interpretação estrita da liberalização do comércio de serviços, sob a perspectiva da não-discriminação, refere-se exclusivamente à proibição das medidas nacionais que desfavoreçam a posição concorrencial de certos ou de todos os prestadores estrangeiros. ${ }^{324}$ No âmbito do tratamento nacional, essas medidas podem envolver a eliminação ou manutenção de um número ilimitado de limitações. O Secretariado da OMC aponta oito deles: (a) impostos e taxas, (b) os subsídios e subvenções, (c) outras restrições financeiras; (d) requisitos de nacionalidade, (e) os requisitos de residência, (f ) qualificações, licenças, normas; (g) requisitos de inscrição e (h) exigências em matéria de autorização (procurar outra fonte para isso). ${ }^{325}$

O conteúdo da cláusula de tratamento nacional é o de que "um Membro poderá satisfazer o disposto no parágrafo $1^{\circ}$ outorgando aos serviços e prestadores de serviços dos demais Membros um tratamento formalmente idêntico ou formalmente diferente do que dispense a seus próprios serviços similares e prestadores de serviços similares" (Artigo XVII:2). Para tanto, um "tratamento formalmente idêntico ou formalmente diferente será considerado menos favorável se modificar as condições de competição em favor dos serviços ou prestadores de serviços do Membro em comparação com serviços similares ou prestadores de serviços similares de qualquer outro Membro" (Artigo XVII:3).

\footnotetext{
${ }^{324}$ GROSBON, Sophie. Le droit à l'enseignement supérieur et la liberalisation international du commerce des services, p. 24-25.

${ }^{325}$ VERGER, Antoni. Measuring educational liberalisation. A global analysis of GATS, Globalisation, Societies and Education, v.6, n.1, 2009, p. 26.
} 


\subsubsection{Liberalização do comércio de serviços por meio da lista positiva}

Em comparação com outros acordos comerciais, a flexibilidade sob a modalidade de lista positiva do GATS se destaca. Ao inserir no cronograma os compromissos de liberalização, permite-se aos Estados assumir compromissos de tratamento nacional e acesso a mercados especificando a natureza do tratamento ou acesso oferecido aos serviços ou prestadores estrangeiros. Assim, os Membros estão autorizados a reservar o direito de manter ou adotar medidas inconsistentes com as obrigações de acesso a mercados e tratamento nacional. Isso é feito mediante reservas nas respectivas áreas dos cronogramas, estratégia que leva alguns autores a descreverem a abordagem do GATS como de "lista positiva/negativa" ou mesmo "abordagem híbrida". ${ }^{326}$ Desse modo, as obrigações de liberalização somente abrangem os setores listados, que por sua vez estão também sujeitos às limitações ou condições inscritas. Nada especifica se essas limitações se referem a medidas não conformes já existentes ou futuras.

Assumindo compromissos específicos em acesso a mercados e tratamento nacional, os países ainda poderão impor limitações, mas de uma maneira neutra em relação à origem e à nacionalidade do prestador de serviços e do investimento. Por outro lado, a decisão de não oferecer compromissos específicos significa sobretudo o desejo do país em permanecer livre para manter ou introduzir medidas inconsistentes com uma igualdade de acesso a mercados ou tratamento nacional em relação à presença de estrangeiros que cheguem ao país para oferecer serviços em educação superior. ${ }^{327}$ Desse modo, a não obrigatoriedade de assumir qualquer compromisso na Parte III do GATS oferece aos Membros diferentes maneiras pelas quais os compromissos específicos podem ser condicionados de forma a respeitar os objetivos político-regulatórios nacionais, ${ }^{328}$ inclusive a possibilidade de assumir compromissos que não refletem sequer o status quo regulatório, ${ }^{329}$ alternativas que tendem a ser

\footnotetext{
${ }^{326}$ ORTINO, Federico. Services, p. 192-193.

${ }^{327}$ COTTIER, Thomas; BREINING-KAUFMANN, Christine and KENNETT, Maxine. Liberalisation of Higher Education Services in Switzerland: The Impact of the General Agreement on Trade in Services (GATS). In: OFES, Office federal de l'éducation et de la science. Les effets de l'AGCS sur le système éducatif suisse. Berne, 2003, p. 75.

${ }^{328}$ LIM, Aik Hoe; SANER, Raymond. Rethinking Trade in Education Services: A Wake-Up Call for Trade Negotiators, p. 1018.

${ }^{329}$ MATOO, Aaditya; SAUVÉ, Pierre. Services. In: CHAUFFOUR, Jean-Pierre; MAUR, JeanChristophe (ed.). Preferential Trade Agreement Policies for Development: A Handbook. Washington: The World Bank, 2011, p. 251; e ROY, Martin; MARCHETTI, Juan; LIM, Hoe. Services liberalization
} 
replicadas nos acordos preferenciais de comércio que apresentam uma abordagem de lista positiva.

Particularmente, em serviços educacionais, no âmbito do GATS, verificase a tendência de não oferecer aos prestadores de serviços estrangeiros compromissos específicos além das oportunidades de acesso a mercados já existentes nas respectivas normativas domésticas. Não só isso, independente das restrições existentes na legislação nacional, os negociadores tendem a introduzir restrições explícitas nesse sentido. ${ }^{330}$

Se é verdade que os países mantêm o pleno direito de não assumir compromissos específicos de acesso a mercados e tratamento nacional, ao mesmo tempo, ao aderir à $\mathrm{OMC}$, eles automaticamente se submetem às regras gerais do GATS. Assim, ainda que não assumam compromissos específicos em matéria educacional, estão comprometidos em relação às obrigações referentes aos deveres gerais de transparência - publicar todas as leis relevantes quanto aos serviços de ensino superior de acordo com o Artigo III do GATS e tornar disponíveis remédios legais contra decisões administrativas que se inserem no âmbito do Acordo - e ao compromisso geral de nação mais favorecida - proporcionar iguais oportunidades para os serviços estrangeiros de educação superior e prestadores de diferentes Membros da OMC, segundo o Artigo II do GATS. ${ }^{331}$

\subsubsection{Cronogramas de liberalização}

Para a consolidação dos compromissos oferecidos pelos Membros da OMC, o GATS é baseado em um sistema complexo, no qual as listas de compromissos específicos são anexadas ao Acordo e dele se tornam parte integrante.

\footnotetext{
in the new generation of preferential trade agreements: how much further than the GATS? In: ESTEVADEORDAL, Antoni; SUOMINEN, Kati; TEH, Robert (ed.). Regional Rules in the Global Trading System. UK: Cambridge University Press, 2009, p. 351,

${ }^{330}$ Considerando essa perspectiva, em relatório no qual respondem à Conferência de Universidades Suíças sobre o impacto do GATS, Cottier, Breining-Kaufmann e Kennett apresentam a orientação de que os compromissos específicos do país no âmbito multilateral não deveriam ir além das obrigações existentes na lei doméstica suíça (Liberalisation of Higher Education Services in Switzerland: The Impact of the General Agreement on Trade in Services (GATS), p. 73).

${ }^{331}$ COTTIER, Thomas; BREINING-KAUFMANN, Christine and KENNETT, Maxine. Liberalisation of Higher Education Services in Switzerland: The Impact of the General Agreement on Trade in Services (GATS), p. 75.
} 
Resultado de negociações comerciais progressivas, as listas de compromissos específicos indicam o tratamento mínimo que cada Membro oferece aos prestadores de serviços educacionais dos outros Membros. ${ }^{332}$

Os compromissos feitos pelos países referem-se a setores e subsetores cuja nomenclatura atende à classificação central de produtos elaborada pelas Nações Unidas, adotada pelo GATS tendo em vista a necessidade da conceituação exata e previsibilidade das regras. São estabelecidas cinco categorias principais para os serviços educacionais: a) serviços de educação primária, b) serviços de educação secundária, c) serviços de educação superior, d) educação de adultos, e e) outros serviços educacionais.

A educação superior recebe o código 923 e, na rubrica "outros serviços de educação superior", a ela correspondem os serviços de educação conducentes a um grau universitário ou equivalente, fornecidos por universidades ou escolas profissionais especializadas, cujos programas não enfatizam somente a instrução teórica, mas também o treinamento de pesquisa visando a preparar os estudantes para a participação em trabalhos originais. ${ }^{333}$

Ainda que o seu uso não seja vinculante, ao oferecer compromissos no âmbito do GATS, a maioria dos Membros da OMC têm usado essas categorias e seus respectivos códigos. Poucos são os países que também incluem distinções adicionais nos seus compromissos, como reflexo das diferenças estruturais entre os países quantos aos seus sistemas educacionais: educação pública/privada, educação compulsória/não-compulsória, educação internacional/nacional e escolas que concedem ou não títulos reconhecidos pelo Estado. ${ }^{334}$

Com um formato padrão, as listas contêm tanto compromissos horizontais quanto compromissos específicos. Os primeiros se referem a limitações e compromissos adicionais aplicáveis a todos os serviços incluídos na lista, enquanto os compromissos específicos representam as obrigações mínimas e vinculantes de acesso

\footnotetext{
${ }^{332}$ GROSBON, Sophie. Le droit à l'enseignement supérieur et la liberalisation international du commerce des services, p. 180.

${ }^{333}$ ORGANIZAÇÃO MUNDIAL DO COMÉRCIO. Services sectoral classification list, 10 Jul. 1991 (MTN.GNS/W/120). Disponível em: <www.docsonline.wto.org>.

${ }^{334}$ ORGANIZAÇÃO MUNDIAL DO COMÉRCIO. Conselho sobre Comércio de Serviços. Education services: background Note by the Secretariat. 23 de setembro de 1998 (S/CSS/W/59), p. 2. Disponível em: <www.docsonline.wto.org>.
} 
a mercados e de tratamento nacional que serão apontadas em relação a cada setor consolidado, seus subsetores e modos de prestação de serviços. ${ }^{335}$

A leitura das listas de compromissos é complexa, não só por conta do número de itens que são incluídos, mas também porque os diferentes cabeçalhos são preenchidos usando lógicas distintas. De um lado, a coluna relacionada aos setores de serviços é preenchida com os nomes dos setores e subsetores que os países decidiram liberalizar. De outro lado, as colunas que lidam com acesso a mercados e tratamento nacional são preenchidas a partir do uso dos termos none e unbound. Quando inserido na coluna referente a um setor, subsetor específico ou modo de prestação, o termo none indica a ausência de restrições ou limitações de acesso a mercados e tratamento nacional naquele setor, subsetor específico ou modo de prestação, estando ainda submetido, porém, às condicionalidades decorrentes dos compromissos horizontais porventura inseridos - limitações transversais, aplicadas a todos os compromissos setoriais. Por sua vez, o termo unbound determina a inexistência de qualquer compromisso do país em relação a um setor ou subsetor específico. Desse modo, o país permanece livre para introduzir ou continuar a aplicar, num determinado setor, subsetor específico ou modo de prestação, medidas inconsistentes com o acesso ao mercado e/ou tratamento nacional. ${ }^{336}$

Essas especificidades não facilitam a redação das listas de compromissos específicos, acarretando surpresas mesmo para os países mais preparados. Por consequência, se a clareza nos compromissos específicos evita uma interpretação ampla de acesso a mercados ou tratamento nacional, a falta dela naturalmente pode conduzir a uma liberalização dos serviços educacionais mais ampla do que os países pensavam ter aceito. ${ }^{337}$

\footnotetext{
${ }^{335}$ CELLI JUNIOR, Umberto. Comércio de Serviços na OMC: Liberalização, Condições e Desafios, p. 95.

${ }^{336}$ VERGER, Antoni. Measuring educational liberalisation. A global analysis of GATS, p. 16; KRAFFT, Mathias-Charles. Les effets et la portée des engagements pris par la Suisse dans la cadre du GATS sur le système de l'éducation suisse. In: OFES, Office federal de l'éducation et de la science. Les effets de l'AGCS sur le système éducatif suisse. Berne, 2003, p. 11; e OLIVERIO, Cecília Kaneto. $\mathrm{O}$ direito ao desenvolvimento e o comércio internacional de serviços educacionais, p. 154-155.

${ }^{337}$ A complexidade do GATS não se esgota na eventual imprecisão das listas de compromissos específicos. Para Grosbon, o Acordo possui diversas disposições particularmente imprecisas que limitam a análise de suas consequências em matéria de ensino superior: a interpretação da expressão "serviços prestados no exercício da autoridade governamental"; a determinação da similaridade entre dois prestadores de serviços educacionais para fins do Artigo II e do Artigo XVII; a determinação das relações entre prestadores que ingressam no mercado e aqueles beneficiados pelo tratamento nacional; a determinação da qualificação dos acordos de integração econômica no seio do Artigo V; e a aplicação
} 
Uma vez consolidados, os compromissos específicos das listas nacionais se aplicam a todos os Membros, em conformidade com o tratamento de nação mais favorecida, e não poderão sofrer alterações antes de um período de três anos (Artigo XXI:1,a), de forma a garantir alguma estabilidade às listas. Posteriormente, em teoria, os países podem modificar ou retirar os compromissos existentes em seus cronogramas. Todavia, teriam que negociar um nível satisfatório de compensação com qualquer membro da OMC que tenha sido afetado negativamente pela modificação ou retirada de compromissos. ${ }^{338} \mathrm{Se}$ os Membros em causa não concordarem com a compensação a ser concedida, o assunto será submetido à arbitragem. Também aqui, se for o caso, a compensação deverá ser paga com base no princípio da nação mais favorecida. ${ }^{339}$

\subsubsection{Modos de serviços}

Mais do que inserir formalmente a educação em uma dinâmica eminentemente comercial, o GATS estabelece os subsetores e os modos de prestação por meio dos quais são liberalizados os serviços educacionais, e, consequentemente, também determina os conceitos e as categorias que fazem parte da regulação na matéria. Assim, para os fins do GATS, o Artigo XXVIII define "medida" como qualquer medida adotada por um Membro, seja em forma de lei, regulamento, regra, procedimento, decisão, decisão administrativa, ou sob qualquer outra forma. Já a "prestação de um serviço" inclui a produção, distribuição, comercialização, venda e entrega de um serviço.

Para os propósitos do GATS, em uma disposição que é repetida nos acordos preferenciais de comércio assinados posteriormente, o comércio de serviços é definido como a prestação de um serviço:

do movimento temporário de pessoas físicas (modo 4) aos diretores ou professores (GROSBON, Sophie. Le droit à l'enseignement supérieur et la liberalisation international du commerce des services, p. 179).

${ }^{338}$ COTTIER, Thomas; BREINING-KAUFMANN, Christine and KENNETT, Maxine. Liberalisation of Higher Education Services in Switzerland: The Impact of the General Agreement on Trade in Services (GATS), p. 75.

${ }^{339}$ KRAFFT, Mathias-Charles. Les effets et la portée des engagements pris par la Suisse dans la cadre du GATS sur le système de l'éducation Suisse, p. 31. 
- Modo 1 (prestação transfronteiriça), do território de um Membro ao território de qualquer outro Membro, sem que seja necessário o movimento físico do consumidor ou do prestador de serviços;

- Modo 2 (consumo no exterior), no território de um Membro aos consumidores de serviços de qualquer outro Membro, quando o consumidor se desloca para o país do prestador de serviços;

- Modo 3 (presença comercial), pelo prestador de serviços de um Membro, por intermédio da presença comercial, no território de qualquer outro Membro; e

- Modo 4 (movimento temporário de pessoas físicas), pelo prestador de serviços de um Membro, por intermédio da presença de pessoas físicas de um Membro no território de qualquer outro Membro.

Traduzidos para uma dinâmica educacional, as diferentes formas de prestação de serviços podem significar, por exemplo, no modo 1 - ensino à distância, com a expansão desse modelo via internet, e também acordos de franquia entre um prestador estrangeiro e uma instituição local; no modo 2 - mobilidade de estudantes que realizam cursos em instituições em outros países; no modo 3 - estabelecimento de instituições em outros países, incluindo campi estrangeiros e empreendimentos conjuntos (joint ventures) com instituições locais; e no modo 4 - o movimento temporário de professores e pesquisadores, que viajam para outros países para prestar serviços. $^{340}$

Enquanto a separação em modos é feita para fins de regulação e não representam necessariamente conceitos empregados pelos prestadores de serviços educacionais $^{341}$, as categorias educacionais são baseadas na estrutura tradicional do setor. Porém, rápidas mudanças que têm lugar sobretudo na educação superior podem afetar significativamente seu alcance e conceito. ${ }^{342}$ Os prestadores de serviços não identificam separadamente suas atividades de acordo com os modos de prestação trazidos pelo GATS, sendo cada vez mais comum a combinação entre dois ou mais modos, dificultando qualquer categorização. É o caso, por exemplo, da semelhança

\footnotetext{
${ }^{340}$ ALTBACH, Philip G.; KNIGHT, Jane. The Internationalization of Higher Education: Motivations and Realities, p. 291-292.

${ }^{341}$ RAYCHAUDHURI, Ajitava; DE, Prabir. Barriers to Trade in Higher Education Services Empirical Evidence from Asia-Pacific Countries, p. 77.

${ }^{342}$ ORGANIZAÇÃO MUNDIAL DO COMÉRCIO. Conselho sobre Comércio de Serviços. Education services: background Note by the Secretariat, p. 1 .
} 
dos acordos de franquia e twinning (modo 1) com o estabelecimento de campi estrangeiros (modo 3), ainda que no primeiro não seja estabelecida nenhuma forma de presença comercial. ${ }^{343}$

De modo geral, em termos de serviços educacionais, a mobilidade de estrangeiros através das fronteiras (modo 2) é a forma predominante. A crescente concorrência por estudantes estrangeiros se faz acompanhar por iniciativas de marketing das instituições de ensino superior. Tais iniciativas, patrocinadas por governos, universidades e empresas privadas, consistem na disseminação de informações sobre as instituições e no recrutamento de estudantes. ${ }^{344}$ No extremo oposto, o menor número de compromissos refere-se ao movimento temporário de pessoas físicas (modo 4), principalmente por conta da proximidade com questões de política migratória. Nesse sentido, o já citado estudo de Cottier, Breining-Kaufmann e Kennett $^{345}$ questiona a restrição à presença de pessoas físicas nos compromissos suíços junto à OMC, que poderia contrariar os interesses das suas universidades relacionados à atração de pesquisadores de excelência. Segundo os autores, uma medida que estenda o acesso ao mercado de trabalho nas universidades suíças facilitaria o recrutamento, em especial de pesquisadores provenientes de países nãoeuropeus.

Entre um modo relativamente comum (modo 2) e outro ainda bastante incipiente (modo 4), os outros dois modos de serviços são os que mais crescem atualmente. Do modo 1, por meio do ensino à distância e acordos de franquia, Estados Unidos, Austrália e Reino Unido são os maiores fornecedores, com boa parte dos programas de suas instituições direcionados para a Ásia, especialmente na China, em Cingapura e na Malásia. Por sua vez, o modo 3 tem se expandido significativamente, tanto pela aquisição de instituições educacionais privadas por grandes grupos empresariais quanto por meio do estabelecimento de campi internacionais, ambos também majoritariamente de origem dos Estados Unidos, Austrália e Reino Unido.

\footnotetext{
${ }^{343}$ LIM, Aik Hoe; SANER, Raymond. Rethinking Trade in Education Services: A Wake-Up Call for Trade Negotiators, p. 1002.

${ }^{344}$ ORGANIZAÇÃ̃O MUNDIAL DO COMÉRCIO. Conselho sobre Comércio de Serviços. Education services: background Note by the Secretariat, p. 7.

${ }^{345}$ COTTIER, Thomas; BREINING-KAUFMANN, Christine and KENNETT, Maxine. Liberalisation of Higher Education Services in Switzerland: The Impact of the General Agreement on Trade in Services (GATS), p. 75.
} 
Entre o período de 2006 e 2009, o número de campi estabelecidos em outros países aumentou cerca de $43 \%$, especialmente na região da Ásia-Pacífico e no Oriente Médio. Considerando os dados trabalhados por Lim e Saner ${ }^{346}$, gerados por uma pesquisa do Observatory on Borderless Higher Education, as instituições dos Estados Unidos continuam a representar a maior parte dos campi internacionais existentes, com 78 campi (48\%). É seguido pela Austrália (14 campi, 9\%), pelo Reino Unido (13 campi, 8\%), e França e Índia (cada uma com 11 campi, 7\%). Ao mesmo tempo, também alguns países em desenvolvimento têm estabelecido campi em outros Estados, especialmente empreendimentos conjuntos (joint ventures) de Índia, China, Malásia e Cingapura com outras economias asiáticas e também na África. Os países que mais recebem campi de instituições estrangeiras são Emirados Árabes Unidos (40 campi, 25\%), China (15 campi, 9\%), Cingapura (12 campi, 7\%) e Catar (9 campi, $6 \%$ ). Inicialmente, a estratégia desses países envolvia a ida de seus estudantes para o exterior, obtendo lá seus títulos. Ao longo da última década a ênfase passou à abertura do acesso para instituições estrangeiras operarem no seu território, através do modo 1 ou modo 3, em uma estratégia que busca diminuir custos e se ampara também na esperança de um impacto positivo sobre o setor educacional como um todo, já que a educação presencial ocorre por meio de colaboração com parceiros locais. ${ }^{347}$

\subsubsection{Exclusão dos serviços prestados no exercício da autoridade governamental}

O GATS abrange todos os serviços exceto aqueles prestados no exercício da autoridade governamental, definidos como qualquer serviço que não é prestado com fins comerciais (lucrativos) ou em concorrência com um ou mais prestadores de serviços. Para ser excluído do âmbito de aplicação do GATS, o serviço em questão deve reunir estas duas condições. Porém, grande parte dos serviços prestados no exercício da autoridade governamental são também prestados pelo setor privado, numa mescla de prestação e financiamento públicos e privados, o que abrange muitos aspectos de educação, saúde, serviços sociais, entre outros.

\footnotetext{
${ }^{346}$ LIM, Aik Hoe; SANER, Raymond. Rethinking Trade in Education Services: A Wake-Up Call for Trade Negotiators, p. 1012.

${ }^{347}$ LIM, Aik Hoe; SANER, Raymond. Rethinking Trade in Education Services: A Wake-Up Call for Trade Negotiators, p. 1016.
} 
Ao mesmo tempo em que o GATS não define o que é "concorrência" e tampouco o que é "base comercial", também não há um modelo unificado de prestação governamental de serviços educacionais, o que demandaria que a abrangência da exceção fosse determinada casuisticamente. ${ }^{348}$ Nesse sentido, as leituras quanto ao alcance da exceção sobre os serviços educacionais, em especial sobre a educação pública, conduzem a diferentes direções. Sinclair ${ }^{349}$ entende que a prestação de serviços educacionais em concorrência com entidades privadas faz com que a exclusão dos "serviços prestados no exercício da autoridade governamental" pareça não proteger muitos dos aspectos da educação pública. Por sua vez, Federico Ortino $^{350}$ vai mais longe, no sentido de que, mesmo com as incertezas em relação às exigências cumulativas de não-lucratividade e não-concorrência, a natureza do serviço em si ou as características do prestador de serviços seriam irrelevantes para fins de decidir o alcance dessa exceção, de modo que, salvo uma pequena parte de serviços governamentais - como polícia e exército -, a noção de serviços no GATS se aplicaria a todos os serviços. Já Anthony Vanduzer ${ }^{351}$ acredita que a exclusão dos serviços prestados no exercício da autoridade governamental tende a ser interpretada de maneira mais generosa do que temem os críticos, no sentido de que a simples coexistência de serviços públicos e privados não deve levar à conclusão de que os serviços públicos estão em concorrência. Assim, considerando o ingresso de várias entidades privadas no setor educacional e a sua convivência com a educação pública, Umberto Celli ${ }^{352}$ separa os serviços prestados no exercício da autoridade governamental por entidades públicas sem finalidade lucrativa daqueles prestados por entidades privadas que operam sob bases comerciais, de forma que somente os serviços educacionais prestados por estas últimas poderiam ser objeto de liberalização comercial no âmbito do GATS.

\footnotetext{
${ }^{348}$ LIM, Aik Hoe; SANER, Raymond. Rethinking Trade in Education Services: A Wake-Up Call for Trade Negotiators, p. 1018.

${ }^{349}$ SINCLAIR, Scott. GATS: How the World Trade Organization's new 'services' negotiations threaten democracy, p. 5.

${ }^{350}$ ORTINO, Federico. Services, p. 188.

${ }^{351}$ VANDUZER, J. Anthony. Navigating between the Poles: Unpacking the Debate on the Implications for Development of GATS Obligations Relating to Health and Education Services. In: PETERSMANN, Ernst-Ulrich (edit.). Reforming the World Trading System: Legitimacy, Efficiency and Democratic Governance. Oxford: Oxford University Press, 2005, p. 194.

${ }^{352}$ CELLI JUNIOR, Umberto. Serviços Educacionais no GATS: desafios para o Brasil. Revista Pontes, v. 4, p. 05-06, 2008.
} 
De todo o modo, mesmo com a exceção do Artigo 1:3(b) e (c), alguns países têm excluído os serviços educacionais públicos ou com financiamento público de seus compromissos específicos. Da mesma forma, nos acordos preferenciais de comércio assinados na esteira do GATS a referida exceção é repetida, seja com a exclusão dos serviços prestados no exercício da autoridade governamental, de maneira horizontal, da cobertura do capítulo de serviços; seja com as reservas formuladas nos acordos de lista negativa, tomadas sobre o direito de manter ou impor novas medidas sobre serviços educacionais públicos, considerando que estes seriam serviços sociais mantidos ou estabelecidos para um fím ou interesse público. ${ }^{353}$

\subsection{Do multilateralismo para os acordos preferenciais de comércio}

O comércio de serviços está na mesa de negociações da OMC e também em um número cada vez maior de acordos preferenciais de comércio bilaterais e regionais. No âmbito da Rodada Doha da OMC, desde 2006, negociações plurilaterais vêm sendo encaminhadas entre um grupo de aproximadamente 30 países, que compreende membros da OCDE e as maiores economias em desenvolvimento. As solicitações de acesso a mercados e tratamento nacional têm incidido sobre os setores jurídico, arquitetura/engenharia, computação, postal/correios, telecomunicações, audiovisual, construção, distribuição, meio ambiente, financeiro, marítimo, transporte aéreo, energia, e educação. ${ }^{354}$ Naquele momento, os países mais frequentemente visados pelas solicitações eram países de renda média que, em sua maior parte, ainda não haviam ingressado em acordos preferenciais de comércio com países desenvolvidos - África do Sul, Argentina, Brasil, China, Egito, Filipinas, Índia, Indonésia, Malásia, Paquistão, Tailândia e Turquia. ${ }^{355}$

\footnotetext{
${ }^{353}$ LIM, Aik Hoe; SANER, Raymond. Rethinking Trade in Education Services: A Wake-Up Call for Trade Negotiators, p. 1021.

${ }^{354}$ HOEKMAN, Bernard; MATTOO, Aaditya. Services Trade Liberalization and Regulatory Reform: Re-invigorating International Cooperation. The World Bank Policy Research Working Paper 5517, Jan. 2011, p. 3. Disponível em: http://elibrary.worldbank.org/content/workingpaper/10.1596/1813-94505517.

${ }^{355}$ FINK, Carsten. Preferential Trade Agreements in Services: Friends or Foes of the Multilateral Trading System? SciencesPos, Groupe d'Économie Mondiale Discussion Paper, Dez. 2007, p. 20. Disponível em: po.fr/content/publications/pdf/Fink_PTA_multilateral_trading_system070208.pdf.

www.gem.sciences-
} 
Em particular, no setor educacional, um dos setores que menos atraem compromissos junto à $\mathrm{OMC}^{356}$, Austrália, China, Estados Unidos, Malásia e Nova Zelândia formularam um pedido plurilateral sobre educação privada direcionado a 19 Membros, entre eles o Brasil. ${ }^{357}$ A solicitação buscava novos ou melhores compromissos em relação a serviços educacionais privados, em especial na educação superior privada (CPC 923). As medidas liberalizantes do pedido envolviam a remoção de limitações de acesso a mercados e tratamento nacional nos modos 1 e 2, e compromissos horizontais para o modo 4 que permitam às pessoas físicas prestadoras de serviços educacionais ingressar no mercado daqueles países. Para o modo 3 foi pedido tanto o pleno acesso a mercados quanto o tratamento nacional sem restrições, ou, se isto não fosse possível, a manutenção somente temporária de restrições quanto à participação de capital estrangeiro em seus cronogramas. ${ }^{358}$

Ainda que os pedidos em geral tenham sido menos ambiciosos do que os primeiros pedidos no sistema solicitação-oferta do GATS $^{359}$, as melhores ofertas até então seriam em média pelo menos duas vezes mais restritivas do que a política atual dos países. Nesse sentido, de acordo com Jara e Domínguez ${ }^{360}$, as negociações comerciais não foram utilizadas efetivamente para garantir um maior acesso a mercados para serviços e investimentos para a maior parte dos membros da OMC. Os avanços na matéria corresponderiam sobretudo à consolidação parcial das reformas domésticas, tanto em países desenvolvidos quanto em desenvolvimento. ${ }^{361} \mathrm{O}$ descontentamento dos Membros mais ativos se refere majoritariamente à ausência de novos compromissos na maior parte dos setores; poucas melhoras nos compromissos horizontais em modo 4; e a persistência das exceções ao tratamento de nação mais

\footnotetext{
${ }^{356}$ ROY, Martin; MARCHETTI, Juan; LIM, Hoe. Services liberalization in the new generation of preferential trade agreements: how much further than the GATS? p. 341.

${ }^{357}$ CELLI JUNIOR, Umberto. Serviços Educacionais no GATS: desafios para o Brasil.

${ }^{358}$ THAM, Siew Yean. Trade in Higher Education Services in Malaysia: Key Policy Challenges. Higher Education Policy, v. 23, 2010, p. 113-114.

${ }^{359}$ HOEKMAN, Bernard; MATTOO, Aaditya. Services Trade Liberalization and Regulatory Reform: Re-invigorating International Cooperation, p. 3-21.

${ }^{360}$ JARA, Alejandro, DOMÍNGUEZ, M. del Carmen. Liberalization of Trade in Services and Trade Negotiations, Journal of World Trade, v. 40, n. 1, 2006, p. 2-3.

${ }^{361}$ Marchetti adverte, no entanto, que os cronogramas de compromissos, em geral, proporcionam uma imagem incompleta do nível real de liberalização do mercado. Primeiro, porque os compromissos na maior parte dos setores foram feitos no final da Rodada Uruguai. Segundo, porque a ausência de compromissos em um setor ou modo de prestação particular não poderia ser tomado como indicador de que o acesso ao mercado é proibido ou que que prestadores estrangeiros são discriminados. (MARCHETTI, Juan A. Developing Countries in the WTO Services Negotiations, p. 9)
} 
favorecida, das provas de necessidade econômica ou de outras limitações nos cronogramas dos Membros.

Assim, em um contexto no qual as negociações na OMC não avançam na velocidade e profundidade desejada pelas principais economias, os acordos preferenciais de comércio têm proliferado. Os capítulos sobre o comércio de serviço representam um fenômeno ainda recente, mas já oferecem caminhos alternativos ou complementares às regras multilaterais. Há um rápido crescimento no número destes com regras sobre serviços, boa parte notificados desde 2003, durante os principais momentos das negociações sobre serviços no âmbito da Rodada Doha. ${ }^{362}$

Desde o início da década passada, Estados Unidos, Japão e União Europeia - os tradicionais demandantes em negociações sobre serviços, começaram a assinar acordos preferenciais de comércio com disposições sobre serviços com outros parceiros que não somente os seus vizinhos mais próximos. Até então, essas disposições envolviam, de um lado, Estados Unidos, México e Canadá, e, de outro lado, a União Europeia e outros países europeus. Por conseguinte, outros atores centrais nesta área seguiram o mesmo caminho, como, por exemplo, Austrália, Chile, China, Coreia do Sul, Índia, Malásia, México, Noruega, Nova Zelândia, Suíça e Tailândia. Dessa forma, grande parte dos demandantes mais ativos na liberalização do comércio de serviços nas negociações multilaterais é hoje signatária de acordos dessa natureza. 363

Ainda que não se espere que boa parte dos compromissos assumidos nos acordos preferenciais necessariamente resulte em uma liberalização real - com a remoção de restrições anteriormente aplicadas - os Membros envolvidos nestes acordos têm assumido compromissos em uma proporção de setores e subsetores de serviços muito superior ao que tinham assumido no GATS ou ainda em relação ao que tinham proposto nas ofertas da Rodada Doha. Esse contraste com o GATS é ainda superior no caso dos países em desenvolvimento, cujos compromissos tendem a ser mais limitados na esfera multilateral. ${ }^{364}$ No âmbito dos acordos preferenciais, os

\footnotetext{
${ }^{362}$ ADLUNG, Rudolf; MOLINUEVO, Martin. Bilateralism in Service Trade: Is There Fire Behind the (BIT-)Smoke? World Trade Organization Staff Working Paper ERSD-2008-01, Jan. 2008, p. 1. Disponível em: http://ssrn.com/abstract=1086304.

${ }^{363}$ ROY, Martin; MARCHETTI, Juan; LIM, Hoe. Services liberalization in the new generation of preferential trade agreements: how much further than the GATS? p. 319.

364 ORGANIZAÇÃ̃ MUNDIAL DO COMÉRCIO. World Trade Report 2011. The WTO and preferential trade agreements: From co-existence to coherence, p. 134. Disponível em:
} 
compromissos desses países vêm se espalhando por todos os setores, com avanços significativos em áreas sensíveis, como serviços ambientais, de distribuição e educação, setores que merecem cuidados de forma a garantir espaço para políticas públicas ligadas às políticas nacionais de desenvolvimento.

Os acordos preferenciais podem ser considerados como OMC-plus ${ }^{365}$, avançando tanto setorialmente quanto em termos regulatórios se comparados com as listas do GATS. ${ }^{366}$ Mesmo os acordos que seguem o modelo inspirado no GATS oferecem cronogramas de compromissos mais liberais. Os que optam por seguir o modelo do NAFTA tendem a mirar a cobertura universal de todos os setores em seus cronogramas de compromissos, abordagem que se afasta da flexibilidade e da liberalização progressiva do GATS. Em acordos Norte-Sul, essa realidade se aplica não só aos países desenvolvidos, mas também aos países em desenvolvimento. Nesse sentido, países como Cingapura, Marrocos e México assumem compromissos plenos em setores nos quais não existiam compromissos no nível multilateral. Mesmo países como Austrália, Estados Unidos e Japão têm mais compromissos em seus acordos bilaterais do que nos seus cronogramas no GATS, talvez como forma de garantir a liberalização do investimento em serviços com parceiros específicos, oferecendo a estes um tratamento substancialmente preferencial como moeda de troca.

Como um setor relativamente pouco consolidado nas listas do GATS, os serviços educacionais encontram um significativo aumento no número de compromissos nos acordos preferenciais de comércio. Para um bom número de países, os compromissos assumidos tendem a atingir os objetivos do pedido plurilateral apresentado na OMC, ou seja, compromissos plenos nos modos 1 e 3 da educação superior privada. A maioria dos compromissos OMC-plus no setor são assumidos por países que são signatários em acordos comerciais com os Estados Unidos, muitos deles com compromissos plenos na totalidade dos cinco subsetores, e

www.wto.org/english/res_e/publications_e/wtr11_e.htm; e ROY, Martin; MARCHETTI, Juan; LIM, Hoe. Services liberalization in the new generation of preferential trade agreements: how much further than the GATS? p. 341.

${ }^{365} \mathrm{~A}$ categoria OMC-plus (WTO-plus) corresponde àquelas disposições de acordos preferenciais de comércio por meio das quais as partes assumem compromissos bilaterais que vão além daqueles acordados previamente no âmbito multilateral (HORN, Henrik; MAVROIDIS, Petros; SAPIR, André. Beyond the WTO? An Anatomy of EU and US Preferential Trade Agreements, The World Economy, v. 33, n. 11, 2010, p. 1567).

${ }^{366}$ HOUDE, Marie-France; KOLSE-PATIL, Akshay; MIROUDOT, Sébastien. The Interaction between Investment and Services Chapters in Selected Regional Trade Agreements. OECD Trade Policy Working Paper No. 55. Paris: OECD Publication, 2007, p. 41-42. 
outros somente com uma única reserva, permitindo a manutenção de medidas já existentes ou a tomada de novas medidas em relação à educação pública. ${ }^{367}$

\subsubsection{Panorama sobre as tendências de regulação nos acordos preferenciais de comércio}

Dada a transferência das negociações do ambiente multilateral para os acordos preferenciais de comércio e a consequente proliferação destes, torna-se fundamental conhecer as tendências de regulação trazidas pelos acordos negociados pelas principais economias. O mapeamento dos compromissos assumidos é fundamental como meio de informar os países em desenvolvimento sobre as escolhas políticas com as quais se confrontarão ao negociar regimes regionais e bilaterais para serviços e investimentos. ${ }^{368}$ Em troca de uma maior abertura dos mercados nos países em desenvolvimento, os países desenvolvidos têm utilizado seus acordos preferenciais de modo a garantir níveis mais profundos de compromissos do que aqueles obtidos na OMC. ${ }^{369}$

Enquanto o GATS, negociado como parte da Rodada Uruguai, representa o acordo pioneiro e, em geral, também o modelo na matéria, muito do recente e atual desenho de novas regras sobre o comércio de serviços, bem como em bens e investimentos estrangeiros, tem se dado em acordos nos âmbitos regional e bilateral. Desse movimento intenso de elaboração e assinatura de acordos de comércio decorre uma complexa e multicamadas rede de regras internacionais a regular o movimento transfronteiriço de serviços e prestadores de serviços. ${ }^{370}$ No âmbito do comércio preferencial, as obrigações em matéria de comércio de serviços são normalmente incluídas em acordos de comércio mais abrangentes, que cobrem não só o comércio de bens, mas também investimentos, propriedade intelectual, comércio eletrônico e concorrência.

\footnotetext{
${ }^{367}$ ROY, Martin; MARCHETTI, Juan; LIM, Hoe. Services liberalization in the new generation of preferential trade agreements: how much further than the GATS? p. 344-345; VERGER, Antoni; PAASSEN, Barbara van. Human development vis-à-vis free trade: Understanding developing countries' positions in trade negotiations on education and intellectual property rights, Review of International Political Economy, iFirst, 2012, p. 6.

${ }^{368}$ MATOO, Aaditya; SAUVÉ, Pierre. Services, p. 236.

${ }^{369}$ ORGANIZAÇÃ̃O MUNDIAL DO COMÉRCIO. World Trade Report 2011, p. 132.

${ }^{370}$ ORTINO, Federico. Services, p. 184-185.
} 
Das notificações à OMC no âmbito do Artigo V do GATS, um pouco mais de um terço dos acordos segue uma estrutura mais próxima ao GATS, com um conjunto semelhante de obrigações que se aplicam aos quatro modos de prestação de serviços e organizam o cronograma de compromissos por meio da modalidade de lista positiva. Não obstante, quase a metade dos acordos regionais sobre comércio de serviços segue uma estrutura diferente da do GATS, próxima àquela trazida pelo NAFTA. Isto significa a adoção da lista negativa para o cronograma de compromissos e também a regulação do comércio de serviços por um conjunto diferente de obrigações. Dessa forma, o acordo é estruturado com um capítulo sobre serviços transfronteiriços focando no modo 1 (prestação transfronteiriça), modo 2 (consumo no exterior) e modo 4 (presença de pessoas físicas); um capítulo sobre investimentos cobrindo todos os setores, incluindo serviços (modo 3 - presença comercial); e capítulos separados sobre telecomunicações, serviços financeiros e entrada temporária de pessoas ligadas a negócios. ${ }^{371}$ Outras disposições sobre o movimento temporário de pessoas físicas são também encontradas em um capítulo adicional. Nesse formato, o modelo NAFTA de lista negativa sujeita o investimento em serviços, incluindo o modo 3, a amplas disposições de investimentos, como expropriação, padrão mínimo de tratamento e mecanismos de solução de controvérsias investidor-Estado. ${ }^{372}$

Esse formato garante via acordos preferenciais de comércio o que os principais países desenvolvidos não haviam conseguido atingir na esfera multilateral. Em um contexto de dificuldades para demarcar precisamente a linha divisória entre o comércio de serviços e investimentos nos primórdios da Rodada Uruguai, a permissão para a imposição de restrições e limitações à presença de prestadores de serviços estrangeiros (presença comercial) assegurava na prática que investimentos não seriam considerados um direito no GATS. ${ }^{373}$ Garantia-se, assim, aos países em desenvolvimento, a possibilidade de regular de maneira apropriada os investimentos. Porém, o tratamento do modo 3 e investimentos sob o capítulo específico de investimentos solapa essa possibilidade, estendendo aos investimentos em serviços as referidas disposições mais restritivas.

\footnotetext{
${ }^{371}$ ORGANIZAÇÃO MUNDIAL DO COMÉRCIO. World Trade Report 2011, p. 133.

${ }^{372}$ ROY, Martin; MARCHETTI, Juan; LIM, Hoe. Services liberalization in the new generation of preferential trade agreements: how much further than the GATS? p. 320.

${ }^{373}$ CELLI JUNIOR, Umberto. Comércio de Serviços na OMC: Liberalização, Condições e Desafios, p. 53 .
} 
Tais especificidades garantem, por si só, efeitos significativos sobre a política de comércio de serviços dos países envolvidos em acordos preferenciais, ainda que as preferências concedidas aos eventuais parceiros possam não ser efetivamente discriminatórias, ou seja, preferências consideradas ainda fracas. Nesse sentido, por exemplo, há acordos preferenciais que reproduzem os compromissos consolidados junto ao GATS, mas trazem mecanismos de solução de controvérsias investidor-Estado que alcançam investimentos em serviços (modo 3) - modelo de solução de disputas não disponível na $\mathrm{OMC}$, permitindo que prestadores privados possam invocar diretamente disciplinas estabelecidas pelo respectivo acordo preferencial em uma corte internacional de arbitragem. Mesmo acordos preferenciais com compromissos que vão além dos compromissos consolidados junto ao GATS, mas não implicam em um liberalização efetiva, cumprem uma função, por meio de garantias vinculantes, de diminuir os riscos de uma mudança na política sobre comércio de serviços para os prestadores de serviços das partes envolvidas. Garantese, assim, que a política da outra parte não se tornará mais restritiva ou, ao menos, mais restritiva do que aquela com a qual se comprometeu. ${ }^{374}$

Por outro lado, considerando somente seus principais blocos de regras, em geral, a maioria dos acordos preferenciais de comércio tende a uma significativa semelhança, tanto entre si quanto em relação ao GATS, ${ }^{375}$ o que significa dizer que os modelos GATS e NAFTA não tomam caminhos diametralmente opostos quanto à regulamentação do comércio de serviços. Contudo, aparecem algumas diferenças relacionadas, sobretudo, ao já referido âmbito de aplicação dos capítulos de serviços, a formulação do padrão de tratamento nacional, os requisitos de transparência, e as disciplinas sobre regulação doméstica. ${ }^{376}$

$\mathrm{Na}$ esfera multilateral, a obrigação de tratamento de nação mais favorecida requer dos Membros da OMC que não haja discriminação entre eles na aplicação das políticas de serviços, no sentido de que um Membro deve conceder aos serviços e prestadores de serviços de qualquer outro Membro um tratamento não menos favorável do que aquele que é concedido aos serviços e prestadores de serviços similares de qualquer outro país. No âmbito dos acordos preferenciais de comércio,

\footnotetext{
${ }^{374}$ FINK, Carsten. Preferential Trade Agreements in Services: Friends or Foes of the Multilateral Trading System? p. 5.

375 ORGANIZAÇÃ̃ MUNDIAL DO COMÉRCIO. World Trade Report 2011, p. 134.

${ }^{376}$ ORTINO, Federico. Services, p. 213.
} 
por sua vez, o tratamento de nação mais favorecida refere-se a uma terceira parte, que não os países signatários do respectivo acordo. Assim, o tratamento em ambas as esferas, ainda que similares em seus efeitos, não deve ser confundido. A inclusão dessa cláusula (non-party MFN clause) nos acordos preferenciais visa, de um lado, a aliviar a discriminação inerente aos acordos de serviços já existentes, e, de outro, a reduzir a discriminação em futuros acordos preferenciais de comércio, na medida em que os países se veem obrigados a estender qualquer preferência comercial negociada aos parceiros preferenciais já existentes. ${ }^{377}$ Em suma, a presença de uma cláusula dessa natureza em acordos bilaterais parte do princípio, estabelecido primeiro no NAFTA, de que os membros de um dado acordo preferencial de comércio automaticamente asseguram qualquer benefício APC-plus que qualquer outra parte ao acordo preferencial original possa estar pensando em conceder a uma terceira parte em um acordo preferencial subsequente. ${ }^{378}$

Incluída na Parte II do GATS, como obrigação geral, as obrigações de transparência são muito comuns nos acordos preferenciais, tanto quando colocados em separado e aplicáveis a todo acordo, a exemplo do NAFTA e nos recentes acordos preferenciais dos Estados Unidos; quanto como disposições específicas encontradas em capítulos individuais, como no capítulo de serviços. Tais obrigações diferem principalmente por duas características importantes: os mecanismos empregados para implementar transparência - obrigações de publicação, provisão de requerimentos de informações, exigências de notificação, de transparência em procedimentos administrativos; e os itens de informação sujeitos às obrigações de transparência. ${ }^{379}$ Uma inovação significativa em relação ao GATS é a disposição em alguns acordos que dá a oportunidade aos Membros de apresentar comentários com antecedência às propostas de alteração nas regulações de serviços. Antes não vinculante, essa regra começa a se tornar juridicamente obrigatória em alguns acordos, notadamente naqueles de cunho Norte-Sul, que seguem uma tendência iniciada pelo Acordo Estados Unidos-Chile e pelo Acordo Estados Unidos-Cingapura. É criado um

\footnotetext{
${ }^{377}$ FINK, Carsten. Preferential Trade Agreements in Services: Friends or Foes of the Multilateral Trading System? p. 8.

${ }^{378}$ MATOO, Aaditya; SAUVÉ, Pierre. Services, p. 243.

${ }^{379}$ ORTINO, Federico. Services, p. 206.
} 
precedente no âmbito do comércio regional com o intuito de facilitar sua subsequente replicação no plano multilateral. ${ }^{380}$

Da mesma forma, regras sobre regulação doméstica podem ser encontradas em vários acordos cobrindo o comércio de serviços. Em geral, essas regras requerem das partes que administrem as leis domésticas de maneira razoável, objetiva e imparcial; estabeleçam mecanismos de revisão e apelação para decisões administrativas; garantam que medidas relativas a requisitos e procedimentos de qualificação, padrões técnicos, e requisitos de licenciamento não constituam barreiras desnecessárias ao comércio de serviços - o chamando "requisito de necessidade"; e façam uso de padrões internacionais relevantes. ${ }^{381}$ Enquanto o Artigo VI do GATS inclui estas regras, mesmo que sujeitas a certas limitações, os acordos preferenciais variam na sua abordagem à regulação doméstica, em geral não ultrapassando aquilo que é fornecido multilateralmente. A matéria é tratada de maneira análoga à encontrada no GATS, sem progressos tangíveis no delineamento de elementos de uma prova de necessidade direcionada a garantir a ampla proporcionalidade entre os meios e os fins da regulação, como indica o mandado do Artigo VI. ${ }^{382}$

De modo geral, os acordos preferenciais de comércio parecem oferecer um limitado valor agregado no que tange às disciplinas do GATS sobre outras áreas regulatórias como mecanismos de salvaguarda e disciplinas sobre subsídios. Com exceções pontuais, os acordos avançaram pouco sobre os pontos inacabados da agenda do GATS. Embora repliquem a exortação multilateral a desenvolver futuras disciplinas sobre subsídios no comércio de serviços, a maioria dos acordos exclui as práticas de subsídios. ${ }^{383}$

No âmbito das disciplinas que correspondem à Parte III do GATS, como já referido, as disposições de acesso a mercados visam a proibir uma série de medidas governamentais que restrinjam a prestação de serviços, independente de sua natureza discriminatória ou não discriminatória. A abordagem de acesso a mercados nos capítulos de serviços dos acordos de comércio diferem de acordo com a lista de medidas em princípio cobertas pela proibição; o conteúdo normativo da prestação; e a

\footnotetext{
${ }^{380}$ MATOO, Aaditya; SAUVÉ, Pierre. Services, p. 243-247.

${ }^{381}$ ORTINO, Federico. Services, p. 209.

${ }^{382}$ MATOO, Aaditya; SAUVÉ, Pierre. Services, p. 247.

${ }^{383}$ ROY, Martin; MARCHETTI, Juan; LIM, Hoe. Services liberalization in the new generation of preferential trade agreements: how much further than the GATS? p. 326.
} 
real abrangência de aplicação, ou seja, se e em que medida a obrigação de acesso a mercados é sujeita a compromissos específicos, condições e/ou reservas. ${ }^{384}$ De todo modo, as medidas em princípio cobertas pela disposição de acesso a mercados correspondem às medidas listadas no Artigo XVI:2(a)-(f) do GATS. Vários acordos seguem exatamente essa abordagem, reproduzindo o texto do Artigo XVI ou incorporando-o ao acordo. Outros, como os mais recentes acordos norte-americanos, seguem um padrão similar, mas omitindo a alínea 'f' do dispositivo do GATS quanto às restrições sobre a participação de capital estrangeiro. No entanto, a ausência dessa medida parece não modificar a natureza liberalizante do acordo, à medida que as restrições sobre o capital estrangeiro, ao menos em princípio, seriam abrangidas pela disposição de tratamento nacional. ${ }^{385}$

Em matéria de tratamento nacional existem algumas pequenas distinções entre o modelo GATS e NAFTA. A regra multilateral determina que cada Membro outorgue aos serviços e prestadores de serviços de qualquer outro Membro, com respeito a todas as medidas que afetem a prestação de serviços, um tratamento não menos favorável do que aquele que dispensa aos seus próprios serviços similares e prestadores de serviços similares. A redação trazida pelo NAFTA e replicada nos acordos preferenciais que repetem esse modelo apresenta duas diferenças principais: a primeira em relação aos beneficiários da disposição - os "serviços e prestadores de serviços", presentes na redação do GATS, são substituídos somente pelos "prestadores de serviços" -; e a segunda em relação ao comparador - o termo "similar é substituído pela expressão “circunstâncias similares”. Essas diferenças textuais podem ter relevantes implicações na proteção dada pela disposição de tratamento nacional. Por exemplo, a expressão "em circunstâncias similares" tem sido empregada pelos tribunais do NAFTA não só para determinar a relação de concorrência entre empresas estrangeiras e domésticas (do mesmo modo que a expressão "similar é interpretada pelos painéis da OMC), mas também como um mecanismo de justificação para políticas públicas. ${ }^{386}$

\footnotetext{
${ }^{384}$ ORTINO, Federico. Services, p. 203.

${ }^{385}$ ORTINO, Federico. Services, p. 203-204.

${ }^{386}$ ORTINO, Federico. Services, p. 201-202.
} 


\subsubsection{Liberalização do comércio de serviços por meio da lista negativa}

Diferentemente da lista positiva característica do GATS, a alternativa representada pela abordagem de lista negativa, aplicada ao comércio de serviços e investimentos, faz com que todos os setores e medidas não conformes sejam liberalizados, com exceção dos especificados de maneira transparente em listas de reservas colocadas como apêndice no acordo. Assim, tudo é liberalizado, salvo o indicado na lista de reservas. As exceções são tipicamente para medidas não conformes existentes (anexo 1) e para medidas futuras (anexo 2). Em geral, as medidas contidas nessas listas são liberalizadas por meio de consultas ou, como no GATS, por meio de reuniões periódicas, se for o caso. ${ }^{387}$

Caracterizado por uma perspectiva top-down, esse modelo apresenta peculiaridades em termos de liberalização comercial. Primeiro, consagra e afirma um compromisso dos signatários frente a um conjunto abrangente de obrigações gerais. Sob o ponto de vista operacional, gera uma forte consolidação do atual piso regulatório, ao mesmo tempo que obriga os signatários a revelar a natureza das medidas não conformes nos setores submetidos a reservas, diferente do GATS. Nesse sentido, ainda que possa garantir um grande nível de transparência, ao pressupor o diálogo entre a política doméstica (regulador) e as comunidades negociadoras ${ }^{388}$ ocasiona claro prejuízo aos setores menos organizados e com menor representação junto aos negociadores comerciais.

Por fim, os acordos preferenciais com lista negativa tendem a apresentar também um mecanismo claramente favorável a uma maior liberalização, chamado de mecanismo de retenção (ratchet mechanism), que complementa a lista negativa de restrições. Assim, se uma parte decide remover unilateralmente algumas barreiras ao investimento, seja em serviços ou não, a manutenção da situação vigente (standstill) aplicar-se-á também a este novo regime, e o país não poderá adotar medidas mais restritivas, salvo mediante compensação ou renegociação com as outras partes. Ou seja, nos acordos em que se faz presente, não só há uma garantia da manutenção do regime consolidado, como também passa a ser incluído nele qualquer

\footnotetext{
${ }^{387}$ MATOO, Aaditya; SAUVÉ, Pierre. Services, p. 251.

${ }^{388}$ MATOO, Aaditya; SAUVÉ, Pierre. Services, p. 252.
} 
nova medida tomada unilateralmente pelas partes no sentido de uma maior liberalização. ${ }^{389}$ Isto cria um movimento de sentido único, liberalizante, garantindo que, uma vez retiradas as restrições, estas não possam ser reintroduzidas.

O recurso à lista negativa é mais comum na área de investimentos, mas isto pode variar de acordo com o setor ou modo de serviço. Por exemplo, lista positiva para comércio transfronteiriço e lista negativa para presença comercial; ou lista negativa para serviços bancários e lista positiva para serviços de seguro. ${ }^{390} \mathrm{~A}$ combinação entre elementos das duas abordagens procura alcançar maior coerência entre disciplinas de serviços e de investimentos, assim como evitar discrepâncias no tratamento de investimentos em bens e serviços ou no tratamento do comércio de serviços sob diferentes modos de prestação. ${ }^{391}$ Em geral, em uma abordagem mista, o modo 3 fica sujeito às mesmas obrigações tanto no capítulo de investimentos quanto no capítulo de serviços.

\subsection{O processo negociador em matéria de serviços educacionais}

A inserção da educação superior em uma lógica de comércio internacional, e as peculiaridades do conjunto de disposições adotadas nos capítulos sobre o comércio de serviços em acordos internacionais trazem desafios para o processo negociador na matéria, a começar com os diferentes impactos regulatórios que a opção pela lista positiva ou pela lista negativa pode gerar. A oposição entre o regulador e o negociador comercial é explorada para apresentar as complexidades das questões regulatórias tratadas, e, principalmente, as complexidades da relação entre ambos no âmbito do processo de negociação em torno da educação superior, com atenção especial ao caso brasileiro.

\footnotetext{
${ }^{389}$ MIROUDOT, Sebástien. Investment. In: CHAUFFOUR, Jean-Pierre; MAUR, Jean-Christophe. Preferential Trade Agreement Policies for Development: A Handbook. Washington: Banco Mundial, 2011, p. 312-314.

${ }^{390}$ MATOO, Aaditya; SAUVÉ, Pierre. Services, p. 254.

${ }^{391}$ ROY, Martin; MARCHETTI, Juan; LIM, Hoe. Services liberalization in the new generation of preferential trade agreements: how much further than the GATS? p. 320.
} 


\subsubsection{A escolha entre o método da lista positiva e o método da lista negativa: impactos regulatórios}

O impacto da adoção de um ou outro modelo de lista sobre a efetiva liberalização comercial pode até alcançar níveis semelhantes. É possível, inclusive, que um acordo com lista positiva conduza a uma maior liberalização do que um acordo com lista negativa. Todavia, é muito mais provável que as duas abordagens gerem diferenças qualitativas significativas, tanto sob uma perspectiva de governança doméstica quanto internacional. Quando feita corretamente, a lista negativa assegura resultados mais profundos em questões de transparência regulatória e consolidação do status quo regulatório. ${ }^{392}$

Com efeito, os países que adotaram abordagens de lista negativa consolidaram ao menos o seu nível existente de abertura/restrições para a maioria dos setores. Essa consolidação faz com que as negociações seguintes sempre partam desse patamar para obter uma real liberalização. Mais do que isso, os acordos nesta modalidade tendem a impor uma proporção maior de disposições GATS-plus, garantido uma série de obrigações novas e mais elaboradas. Diferentemente, todos os acordos que tendem a apresentar menores proporções de novos e mais profundos compromissos adotam uma abordagem de lista positiva. ${ }^{393}$

Assim, na tabela que segue, o alcance da adoção de um ou outro método - lista positiva ou lista negativa -, baseados nos modelos trazidos pelo GATS e pelo NAFTA, respectivamente, pode ser estruturado a partir de seis categorias principais, que abarcam os aspectos fundamentais dos acordos preferenciais de comércio na perspectiva de Houde, Kolse-Patil e Miroudot ${ }^{394}$ : tipos de compromissos ou reservas listas, a existência ou não de compromissos vinculantes, a existência ou não de liberalização adicional, transparência sobre as medidas adotadas, flexibilidade para os países signatários, e previsibilidade.

\footnotetext{
${ }^{392}$ MATOO, Aaditya; SAUVÉ, Pierre. Services, p. 252-253.

${ }^{393}$ ROY, Martin; MARCHETTI, Juan; LIM, Hoe. Services liberalization in the new generation of preferential trade agreements: how much further than the GATS? p. 352.

394 HOUDE, Marie-France; KOLSE-PATIL, Akshay; MIROUDOT, Sébastien. The Interaction between Investment and Services Chapters in Selected Regional Trade Agreements, p. 40.
} 
Tabela 01 - Comparação entre o modelo GATS de lista positiva e o modelo NAFTA de lista negativa para a consolidação de compromissos de liberalização nos acordos preferenciais de comércio

\begin{tabular}{|c|c|c|}
\hline & Método de lista positiva - "modelo GATS" & $\begin{array}{c}\text { Método de lista negativa - "modelo } \\
\text { NAFTA" }\end{array}$ \\
\hline $\begin{array}{l}\text { Tipos de } \\
\text { compromissos ou } \\
\text { reservas listadas }\end{array}$ & $\begin{array}{l}\text { Compromissos de acesso a mercados e } \\
\text { tratamento nacional (cobrindo também } \\
\text { restrições } \\
\text { discriminatórias) }\end{array}$ & $\begin{array}{l}\text { São listadas reservas ao tratamento nacional e } \\
\text { nação mais favorecida }{ }^{396}\end{array}$ \\
\hline $\begin{array}{l}\text { Compromissos } \\
\text { vinculantes? }\end{array}$ & $\begin{array}{l}\text { Compromissos são vinculantes. Manutenção } \\
\text { da situação vigente (standstill) nos setores } \\
\text { onde compromissos são feitos (sujeitos às } \\
\text { reservas listadas) }\end{array}$ & $\begin{array}{l}\text { Compromissos são vinculantes. Manutenção } \\
\text { da situação vigente (standstill) e mecanismo } \\
\text { de retenção (ratchet mechanism) (qualquer } \\
\text { nova liberalização ou medida não-conforme } \\
\text { se torna um compromisso no acordo) }\end{array}$ \\
\hline $\begin{array}{l}\text { Liberalização } \\
\text { adicional? }\end{array}$ & $\begin{array}{l}\text { Liberalização adicional prevista no acordo } \\
\text { por meio da revisão de compromissos } \\
\text { (algumas vezes com o intuito de eliminar } \\
\text { toda a discriminação remanescente no final } \\
\text { de um certo período) }\end{array}$ & $\begin{array}{l}\text { Nenhuma liberalização adicional prevista. O } \\
\text { acordo pode incluir a eliminação gradual de } \\
\text { medidas não-conformes (mas já estipulado } \\
\text { quando o acordo é assinado) }\end{array}$ \\
\hline Transparência & $\begin{array}{l}\text { Nenhuma informação é fornecida nos } \\
\text { cronogramas de compromissos sobre a } \\
\text { liberalização de investimentos em setores de } \\
\text { serviços onde nenhum compromisso é feito. } \\
\text { Contudo, transparência é uma obrigação } \\
\text { geral do acordo e informações sobre o } \\
\text { regime de investimentos em todos os setores } \\
\text { devem ser disponibilizadas }\end{array}$ & $\begin{array}{l}\text { A abordagem top-down oferece um maior } \\
\text { grau de transparência para investidores na } \\
\text { medida em que todos os setores são cobertos } \\
\text { por disciplinas não-discriminatórias e } \\
\text { somente limitações listadas se aplicam. Essa } \\
\text { transparência é reduzida quando algumas } \\
\text { dessas reservas não são listadas }\end{array}$ \\
\hline Flexibilidade & $\begin{array}{l}\text { Os países podem assumir compromissos nos } \\
\text { setores de sua escolha e limitações são } \\
\text { listadas somente em setores consolidados, } \\
\text { deixando alguma flexibilidade quanto ao } \\
\text { grau de liberalização oferecido em outros } \\
\text { setores }\end{array}$ & $\begin{array}{l}\text { Flexibilidade pode ser introduzida por meio } \\
\text { de reservas sobre medidas futuras, mas tais } \\
\text { reservas devem ser tomadas quando o acordo } \\
\text { é assinado }\end{array}$ \\
\hline Previsibilidade & $\begin{array}{l}\text { A previsibilidade é limitada aos setores onde } \\
\text { compromissos são feitos }\end{array}$ & $\begin{array}{l}\text { O mecanismo de retenção consolida qualquer } \\
\text { nova liberalização de uma medida não- } \\
\text { conforme. Novos setores de serviços são } \\
\text { automaticamente cobertos por disciplinas } \\
\text { não-discriminatórias }\end{array}$ \\
\hline
\end{tabular}

Tabela e informações elaboradas por Houde, Kolse-Patil e Miroudot (The Interaction between Investment and Services Chapters in Selected Regional Trade Agreements, p. 40).

\section{Quando se deixa um pouco de lado a similitude entre as principais} disciplinas (tratamento de nação mais favorecida, regulamentação doméstica, acesso a mercados e tratamento nacional) de um modelo de acordo e de outro, como visto

\footnotetext{
${ }^{395} \mathrm{O}$ tratamento de nação mais favorecida é uma obrigação geral que não é encontrada em todos os acordos.

396 Alguns acordos inspirados no NAFTA também listam reservas a obrigações relacionadas a requisitos de desempenho e requisitos de cidadania ou residência para gerentes executivos e conselhos de administração.
} 
anteriormente, e delas se parte para as especificidades dos métodos de lista positiva e de lista negativa, é notório o maior potencial liberalizante desta última. A opção da maior parte dos países desenvolvidos por modelos próximos ao trazido pelo NAFTA no desenho de seus acordos preferenciais de comércio atende, assim, aos interesses exportadores de seus setores produtivos domésticos.

De todo o modo, os objetivos gerais dos dois modelos respondem ao mesmo fim, qual seja a liberalização do comércio de serviços, sob o pretexto de que qualquer país, mesmo os menos desenvolvidos, pode se beneficiar da abertura de mercado. Nem todos teriam o mesmo potencial, e os benefícios da abertura podem ser suplantados pelos custos associados à abertura comercial, de modo que o sucesso seria condicionado pela adoção de reformas complementares, ainda que potencialmente custosas em países com orçamento e recursos humanos limitados. ${ }^{397}$ A agenda de reformas segue a receita das políticas econômicas hegemônicas principalmente nas duas últimas décadas. Para Bernard Hoekman e Aaditya Matoo ${ }^{398}$, em particular no caso do comércio de serviços, esta agenda envolveria o aumento da concorrência dos mercados, a capacidade de assegurar uma regulamentação eficaz para lidar com falhas de mercado, com vista à eficiência, e a realização de objetivos sociais. Para os autores, os instrumentos para atingir tais objetivos seriam, respectivamente, reformas unilaterais, negociações de acesso a mercados e cooperação regulatória.

O poder regulatório do GATS, aliado às capacidades sancionatórias da OMC, ambos eventualmente potencializados em uma rede de acordos preferenciais de comércio que se forma, tornaram o Acordo um elemento central na governança educacional global, construção que se estende por meio dos compromissos consolidados bilateralmente pelos países. Porém, como lembra Verger ${ }^{399}$, a contribuição do GATS à governança global não é em nada neutra na medida em que consolida um ambiente favorável para a livre iniciativa e a expansão do setor privado.

Nesse contexto,

\footnotetext{
${ }^{397}$ CATTANEO, Olivier, ENGMAN, Michael, SÁEZ, Sebastián, e STERN, Robert M. Assessing the potential of services trade in developing countries: an overview. In: CATTANEO, Olivier, ENGMAN, Michael, SÁEZ, Sebastián, e STERN, Robert M. (edits.). International Trade in Services: New Trends and Opportunities for Developing Countries. Washington, D.C.: The World Bank, 2010, p. 1.

${ }^{398}$ HOEKMAN, Bernard; MATTOO, Aaditya. Services Trade Liberalization and Regulatory Reform: Re-invigorating International Cooperation, p. 12-13.

${ }^{399}$ VERGER, Antoni. The constitution of a new global regime: Higher education in the GATS/WTO framework, 115 .
} 
os interesses das corporações globais convergem na busca de regras vinculantes, globais e irreversíveis em matéria de comércio de serviços. Ao expandirem e estenderem seu alcance global, cada vez mais procuram reduzir o custo do cumprimento das regulações que enfrentam em diferentes países. Também se beneficiam da redução da concorrência de empresas domésticas, e da privatização e comercialização de empresas públicas que permitem a eles expandirem sua presença no mercado. Natural, assim, que a adoção de regras globais para reduzir ou eliminar barreiras colocadas por governos em sua atividade comercial internacional seja uma prioridade fundamental de muitas corporações globais que operam nos setores de serviços."

Quando o multilateralismo deixa de ser efetivo na obtenção desse desenho regulatório buscado pelo setor de negócios em serviços, o deslocamento das negociações para a esfera bilateral começa a cumprir esse papel e aprofunda os instrumentos liberalizantes trazidos pelos GATS. A corrida em direção à liberalização do comércio de serviços é um fenômeno que não deve ser interpretado somente na esfera econômica ou comercial, mas também politicamente. ${ }^{401}$ A adoção de compromissos limita o espaço para políticas dos países e conduz a uma redefinição das funções do Estado como regulador, prestador e financiador da educação. Por conseguinte, pode também obstar a utilização de políticas educacionais como instrumento para resolver ou melhorar uma série de outros problemas sociais.

O setor educacional ainda representa um setor sensível na maioria dos países, intimamente ligado a muitas outras prioridades domésticas, de tal forma que os países procuram intervir diretamente no sistema educacional e usá-lo para alcançar outros fins sociais, como a preservação da cultura, desenvolvimento e planejamento de recursos humanos, e estímulo da coesão social e identidade nacional. ${ }^{402}$ Sendo assim, partindo do pressuposto de que também no campo educacional podemos separar de um lado os interesses do regulador doméstico e, de outro, os interesses do negociador comercial, cinco entre as seis categorias utilizadas para comparar os modelos da lista positiva e os modelos da lista negativa na tabela 01 dizem respeito

\footnotetext{
${ }^{400}$ SINCLAIR, Scott. GATS: How the World Trade Organization's new 'services' negotiations threaten democracy, p. 3.

${ }^{401}$ VERGER, Antoni. The constitution of a new global regime: Higher education in the GATS/WTO framework, 115.

${ }^{402} \mathrm{TOH}$, Mun-Heng. Internationalization of Tertiary Education Services in Singapore. Asian Development Bank Institute Working Papers Series No 388, Out. 2012, p. 22. Disponível em: http://papers.ssrn.com/sol3/papers.cfm?abstract_id=2161691.
} 
sobretudo aos interesses particulares dos investidores privados estrangeiros que buscam acesso ao mercado doméstico ou grupos privados nacionais com interesses exportadores; são elas os tipos de compromissos ou reservas listas, os compromissos vinculantes, a liberalização adicional, a transparência e a previsibilidade. Ao regulador educacional interessa acima de todos os outros tópicos a manutenção da flexibilidade para que possa atuar na regulamentação do setor com vista às políticas nacionais de educação.

Essa tensão entre o impulso liberalizante e a flexibilidade do regulador doméstico foi também identificada por Celli:

"um aspecto relevante do GATS relaciona-se à capacidade dos Membros de regular e de introduzir novas regulamentações sobre serviços dentro de seus territórios para atingir seus objetivos nacionais. À medida que a liberalização do comércio de serviços pode resultar na limitação da autonomia reguladora ou legislativa interna dos Membros, na hipótese de as obrigações do GATS requererem a abolição ou a alteração de certas normas e regras e sua aplicação, constata-se um conflito potencial entre o direito de regular e o processo de liberalização. Isso parece indicar que a política nacional de regulação requer um reconhecimento especial vis-à-vis à liberalização do comércio." ${ }^{403}$

Sendo assim, os custos do cumprimento das regras devem ser sopesados em relação aos supostos benefícios em questões de governança. A adoção da lista negativa faz com que os governos renunciem ao direito de introduzir medidas discriminatórias ou que prejudiquem o acesso a mercados no futuro, mesmo em setores que ainda não existam ou não estejam regulados ao tempo em que o acordo entra em vigor. Consequentemente, novos serviços, e serviços que não despertam $a$ priori preocupações quanto ao tratamento nacional ou acesso a mercados são automaticamente incluídos nos acordos. O problema é que, em boa parte dos países em desenvolvimento, o quadro regulatório não evoluiu o suficiente para que se permita identificar com clareza as inconsistências potenciais.

A dificuldade inicial de se verificar todas as leis nacionais e locais em potencial conflito com as disposições de tratamento nacional e de acesso a mercados se soma à tarefa ainda mais complicada de levantar detalhadamente todos os setores e

\footnotetext{
${ }^{403}$ CELLI JUNIOR, Umberto. Políticas de Liberalização do Comércio de Serviços (GATS) com Regulação Redistributiva. Cadernos PROLAM/USP, v. 1, 2009, p. 126.
} 
subsetores que ainda não apresentam condições de serem liberalizados. Nesse contexto, deve-se privilegiar ou dar precedência à autonomia reguladora, ${ }^{404}$ de forma que os elementos centrais do modelo de lista positiva - flexibilidade e liberalização progressiva - tenham maior potencial de assegurar um desenho regulatório mais adequado às especificidades dos países em desenvolvimento, particularmente em setores sensíveis, como o educacional.

\subsubsection{Definição das posições negociadoras em comércio de serviços educacionais: o regulador e o negociador comercial}

A educação é negociada dentro uma relação muito mais ampla de tópicos abrangidos pela rodada de negociação, em um regime de comércio que foi desenhado não a partir da perspectiva da expansão do fluxo de comércio na área da educação, mas sim principalmente de serviços bancários, de seguro e telecomunicações. ${ }^{405} \mathrm{~A}$ educação superior não só é somente um dos mais de 160 subsetores de serviços negociados pelos então signatários do GATS, como também o setor de serviços em seu conjunto faz parte de uma pauta que inclui, considerando a Rodada Doha, além dele, questões de aplicação de regras, acesso a mercados nãoagrícolas, propriedade intelectual, solução de controvérsias, têxteis, agricultura, investimentos, compras governamentais, facilitação de comércio, meio ambiente, comércio eletrônico, débitos e finanças, transferência de tecnologia, países menos desenvolvidos, tratamento especial e diferenciado, e subsídios. ${ }^{406}$

Há, assim, ao menos dois níveis de complexidade: o primeiro que diz respeito à natureza do comércio de serviços e sua singularidade dentro de uma pauta bastante ampla do comércio internacional, em especial se comparado ao comércio de bens; e o segundo relativo à comercialização da educação superior e seu tratamento como serviço educacional, a despeito do seu tratamento histórico como direito

\footnotetext{
${ }^{404}$ CELLI JUNIOR, Umberto. Comércio de Serviços na OMC: Liberalização, Condições e Desafios, p. 83.

${ }^{405}$ VERGER, Antoni. The constitution of a new global regime: Higher education in the GATS/WTO framework, p. 113.

406 VERGER, Antoni. The Merchants of Education: Global Politics and the Uneven Education Liberalization Process within the WTO, p. 9-10.
} 
humano, com posições em geral divergentes entre o regulador e o negociador comercial de um mesmo país.

\subsubsection{Complexidades sob a perspectiva do comércio de serviços - questões regulatórias}

As negociações sobre serviços tocam em uma série de responsabilidades governamentais muito mais ampla do que a concernente às negociações sobre bens. Por isso são mais custosas e demandam mais tempo que as negociações em setores manufatureiros. Essa equação conta com variáveis que se combinam e tornam ainda mais complexa esta tarefa. Por um lado, deve-se considerar a diversidade - nos planos político, institucional e econômico - dos setores envolvidos; de outro, tem-se o quase ilimitado número de medidas comerciais que podem ser legitimamente aplicadas para proteger os mercados. A reversão dessas medidas e a abertura de mercados passam necessariamente por um intrincado sistema regulatório. Se por vezes um simples ato administrativo é suficiente para alterar uma tarifa, as mudanças requeridas por determinados setores de serviços podem exigir amplas alterações legislativas ou até mesmo emendas constitucionais. ${ }^{407}$

Sendo assim, como boa parte das medidas negociadas em acordos comerciais envolvem mudanças na adoção de medidas relacionadas a qualificações, licenciamento e padrões técnicos, os países devem consultar os respectivos órgãos regulatórios domésticos para chegar a posições nacionais bem definidas. Os setores de serviços estão sujeitos a detalhados quadros regulatórios sob o controle de ministérios ou agências que ficam fora da jurisdição das autoridades responsáveis pelo comércio internacional. Isso demanda uma tarefa dos negociadores de mobilizar e coordenar numerosas agências para elaborar pedidos ou ofertas. No entanto, como os mecanismos de coordenação entre negociadores e os reguladores domésticos ainda são fracos, especialmente nos países em desenvolvimento, torna-se mais complexa a avaliação pelos negociadores das implicações de certas propostas e de determinar se

\footnotetext{
${ }^{407}$ ADLUNG, Rudolf; ROY, Martin. Turning hills into mountains? Current commitments under the gats and prospects for change, p. 5-6.
} 
devem apoiar ou rejeitar certos elementos, ainda mais quando não existem níveis prédefinidos de ambição para cada setor ou subsetor e modos de serviços. ${ }^{408}$

As entidades subfederais ou ministérios, agências e associações com os quais se requer coordenação para os processos decisórios, amiúde não possuem experiência em negociações comerciais e, inclusive, não necessariamente apoiam os objetivos em negociação, em especial quando o intuito é a abertura de mercados. Assim, a aversão às obrigações comerciais em setores de serviços protegidos pode ser tão forte quanto em alguns setores manufatureiros tradicionais, principalmente em setores nos quais as condições de acesso são geralmente determinadas em conjunto com os prestadores - caso dos médicos, advogados e contabilistas, por exemplo. ${ }^{409}$

Ao mesmo tempo que os negociadores precisam aprender sobre as preferências e interesses das outras partes, assim como as suas, as negociações invariavelmente envolvem um processo complexo de interação entre os grupos domésticos com vistas à definição dos objetivos/prioridades da negociação. Nesse processo, por que não dizer, de aprendizagem quanto à substância das regras envolvidas, agentes do Estado e sociedade civil precisam entender quais as implicações de uma dada regra proposta e seu possível impacto sobre o respectivo setor. Se as matérias já são complexas quando as negociações circulam em torno de políticas comerciais tradicionais, como tarifas e cotas, tornam-se mais complicadas quando se consideram os serviços, o que quase invariavelmente envolve uma dimensão regulatória. ${ }^{410}$

Essa segmentação de responsabilidades políticas, na esfera doméstica, não parece combinar bem com a estrutura centralizada de negociações na OMC. O crescimento da influência de interesses específicos de distintos grupos na definição da política comercial, em um processo de maior permeabilidade desta, tem como consequência natural um impacto sobre a flexibilidade das posições negociadoras. ${ }^{411}$ Tais dificuldades ajudam a explicar a resistência à agenda multilateral em matéria de

\footnotetext{
${ }^{408}$ JARA, Alejandro, DOMÍNGUEZ, M. del Carmen. Liberalization of Trade in Services and Trade Negotiations, p. 4.

${ }^{409}$ ADLUNG, Rudolf; ROY, Martin. Turning hills into mountains? Current commitments under the gats and prospects for change, p. 4.

${ }_{410}$ HOEKMAN, Bernard; MATTOO, Aaditya. Services Trade Liberalization and Regulatory Reform: Re-invigorating International Cooperation, p. 14.

${ }^{411}$ ADLUNG, Rudolf. Services liberalization from a WTO/GATS perspective: in search of volunteers. World Trade Organization Staff Working Paper ERSD-2009-05, Fev. 2009, p. 9. Disponível em: <http://ssrn.com/abstract=1345018>.
} 
serviços e, ao mesmo tempo, o desenvolvimento do tema em acordos preferenciais de comércio, nos quais a negociação bilateral apresenta resultados mais rápidos, porém, em geral, menos favoráveis aos países em desenvolvimento.

A prática do processo de negociações comerciais, que tende a acontecer em segredo ou com pouca consulta pública, é ainda mais contrastante quando se adota como parâmetro a regulamentação de direitos humanos, que exige a seu turno participação, informação, avaliação e prestação de contas constantes. Uma abordagem de direitos humanos das negociações de comércio necessariamente envolveria uma ampla consulta pública prévia sobre os acordos propostos e uma mais rigorosa avaliação prévia dos prováveis impactos das novas regras, especialmente sobre os setores mais pobres e vulneráveis da população. Alguns poderiam reclamar que isso diminuiria a velocidade das negociações comerciais, mas certamente aumentaria a robustez e legitimidade de qualquer novo acordo. ${ }^{412}$

\subsubsection{Complexidades da relação entre o regulador e o negociador comercial - educação superior}

Os objetivos de reguladores e negociadores comerciais em geral são diferentes e difíceis de equilibrar. Os reguladores tendem a elaborar e implementar políticas regulatórias domésticas que permitirão a prestação de serviços de uma maneira competitiva e efetiva em alguns setores, e com preocupações sociais de acesso e qualidade em outros, enquanto os negociadores procuram tão somente abrir mercado para seus prestadores por meio da liberalização ou eliminação de barreiras discriminatórias, incluindo as regulatórias. Assim, se flexibilidade e autonomia são essenciais para os reguladores, os negociadores procuram previsibilidade. Considerando a natureza política sensível de alguns setores de serviços, incluindo a educação, e o papel central da regulação doméstica, as negociações sobre serviços estão também sujeitas ao constante escrutínio da sociedade civil. ${ }^{413}$

\footnotetext{
${ }^{412}$ DOMMEN, Caroline. Human Rights and Trade: Two Practical Suggestions for Promoting Coordination and Coherence, p. 201.

${ }^{413}$ JARA, Alejandro, DOMÍNGUEZ, M. del Carmen. Liberalization of Trade in Services and Trade Negotiations, p. 5.
} 
No processo de tomada de decisões, Verger entende ser necessário antes de tudo entender quem representa o Estado dentro da OMC e das demais negociações comerciais ${ }^{414}$. Especificamente no Brasil, os representantes do Estado na OMC são ligados ao Ministério das Relações Exteriores (MRE) e ao Ministério do Desenvolvimento, Indústria e Comércio Exterior (MDIC). Isso traz importantes implicações sobre como as decisões são enquadradas e quem diretamente afeta o resultado final. Ainda que os acordos comerciais tenham que ser ratificados pelos parlamentos nacionais na maioria dos países, o procedimento completo é coordenado pelos especialistas comerciais que controlam os dados e o conhecimento sobre a matéria, bem como as informações-chaves sobre o processo negociador. Os negociadores comerciais conduzem as negociações e, frequentemente, de acordo com as suas posições particulares, influenciam as visões dos reguladores e envolvidos do setor privado.

Nas negociações regionais e multilaterais a prioridade do Brasil concentra-se no acesso a mercados em matéria agrícola e em uma posição ofensiva em produtos industrializados. Além da ausência de uma pauta ofensiva em matéria de serviços, faltam também informações e conteúdo de análise - conceitos, prioridades, dificuldades, estatísticas, etc. -, salvo em setores mais articulados, como o bancário e de telecomunicações. Todavia, com um setor de serviços dinâmico, em um contexto de crescimento econômico, a tendência é ter uma mobilização das entidades representativas específicas que ainda não são atuantes, sob pena de não terem suas posições representadas.

Nesse processo de comunicação e/ou cooperação entre os negociadores e os ministérios na definição das posições em torno de setores de serviços específicos, Verger ${ }^{415}$ identifica dois tipos de consulta entre ambos, caracterizados por uma intensidade forte ou consultas leves. No primeiro caso, o regulador é perguntado se quer ou não que o seu setor seja aberto e, assim, tem a oportunidade de diretamente definir a posição do país na matéria. Alternativamente, a segunda hipótese corresponde ao caso no qual os negociadores comerciais podem conduzir consultas consideradas leves ao perguntar ao regulador como ele ajustaria alguns aspectos

\footnotetext{
${ }^{414}$ VERGER, Antoni. The Merchants of Education: Global Politics and the Uneven Education Liberalization Process within the WTO, p. 11-12.

415 VERGER, Antoni. The Merchants of Education: Global Politics and the Uneven Education Liberalization Process within the WTO, p. 15.
} 
técnicos e regulatórios se compromissos de liberalização comercial fossem adotados no seu setor. Nesse caso, a decisão de abrir o mercado já foi tomada pela área comercial/negociadora do país, antes mesmo da consulta ao ministério diretamente interessado. Na pesquisa de campo conduzida por Verger junto aos atores internacionais com participação direta no subsistema de negociação do GATS (de um lado, negociadores comerciais na OMC e staff da organização; e, de outro lado, as partes interessadas do setor educacional, sobretudo na Argentina e no Chile), ainda que se verifique a ocorrência dos dois modelos de negociação, o forte e o leve, a abordagem leve é a mais comum.

No continente sul-americano, Chile, Colômbia e Peru têm consolidado compromissos comerciais em matéria educacional. Argentina, Brasil e Venezuela tomam o caminho oposto. Segundo Verger ${ }^{416}$, a decisão de não oferecer compromissos em educação nesses países está associada com condições políticas domésticas, mais especificamente: a) a orientação ideológica dos governos; b) a receptividade dos governos às demandas dos setores contrários ao GATS, normalmente universidades públicas e sindicatos de professores; e c) por fim, a intervenção dos Ministros da Educação no processo de negociação, declarando publicamente que a educação não poderia ser comprometida em acordos de comércio.

Essa hipótese parece se confirmar no Brasil, com algumas manifestações públicas de ao menos dois Ministros da Educação, a partir de 2005. Primeiro, em um debate sobre a inclusão da educação no GATS, em junho de 2005, o então Ministro da Educação, Tarso Genro (que exerceu o cargo do início do ano de 2004 até julho de 2005), defendeu que o Brasil não apresentasse qualquer oferta de abertura do setor educacional ${ }^{417}$. Tal posição partiu da definição da educação como um direito e um bem público, que, ao ser regulamentada e supervisionada pelo Estado, fortaleceria a identidade cultural do seu povo, além de representar um compromisso com a elevação dos níveis de bem-estar social. Nesse raciocínio, o Ministro considerava que sua inclusão como serviço poderia conduzir a uma limitação do poder de regulamentação e da defesa da educação pública, gratuita e de qualidade. Por conseguinte, ficariam comprometidas as reformas educacionais, nelas incluídas a

\footnotetext{
${ }^{416}$ VERGER, Antoni. The Merchants of Education: Global Politics and the Uneven Education Liberalization Process within the WTO, p. 16.

${ }^{417}$ LORENZONI, Ionice. MEC não quer o ingresso da educação na OMC. Ministério da Educação, 07 de junho de 2005 Disponível em: http://portal.mec.gov.br/index.php?option=com_content\&view=article\&id=3219\&catid=221.
} 
reforma universitária, as políticas afirmativas e de correção dos desequilíbrios sociais e regionais.

Organizada pela Comissão de Educação da Câmara dos Deputados, a audiência pública contou com representantes da Associação Nacional dos Dirigentes das Instituições Federais de Ensino Superior (Andifes) e da União Nacional de Estudantes (UNE), e com o então chefe da Divisão de Serviços, Investimentos e Assuntos Financeiros do Ministério das Relações Exteriores (MRE), Ernesto Henrique Fraga Araújo. Na ocasião, o representante do MRE confirmou a educação, junto com saneamento e saúde, como setores que estariam fora da lista de ofertas do Brasil à OMC, em decorrência do movimento da sociedade civil, de entidades de professores e alunos e da própria posição do MEC. ${ }^{418}$ Essa posição reforçou a afirmação feita ainda antes pelo então Secretário da mesma Divisão, Alexandre Mendes Nina, referindo-se à relação entre as negociações de serviços e educação, de que estaria longe a época em que o negociador brasileiro se via em uma mesa de negociações no exterior "sem conhecimento da realidade, daquilo que ocorria dentro do País, ou melhor, sem um conhecimento preciso das demandas que constituem o interesse nacional nessas negociações." ${ }^{419}$

Em março de 2006, a assessoria internacional do Ministério da Educação organizou uma reunião com sua consultoria jurídica e diversos secretários, negociadores do MRE, o então presidente da Associação Nacional dos Dirigentes das Instituições Federais de Ensino Superior (ANDIFES), a então secretária-executiva do Conselho Nacional de Secretários de Educação (CONSED) e o representante do Fórum de Assessorias das Universidades Brasileiras para Assuntos Internacionais (FAUBAI). No encontro, os representantes do MRE explicaram os detalhes técnicos do processo negociador e da posição brasileira, enquanto foram informados pelo MEC da importância de defender o princípio de que a educação não poderia ser considerada como um negócio. ${ }^{420}$

\footnotetext{
${ }^{418}$ LORENZONI, Ionice. MEC não quer o ingresso da educação na OMC.

${ }^{419}$ NINA, Alexandre Mendes. Situação geral das negociações de serviço no âmbito do GATS, Revista da Associação Brasileira de Mantenedoras de Ensino Superior, v. 22, n. 33, Abr. 2004, p. 36.

${ }^{420}$ JAPPE, Lívia. Brasil rejeita, na OMC, proposta de abertura do setor de educação. Ministério da Educação, 17 de maio de 2006.2 Disponível em:

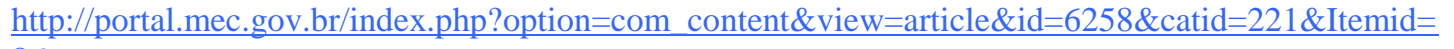
86.
} 
Logo após, o Brasil rejeitou proposta para abrir o setor de educação na OMC, durante reunião em Genebra. Naquele momento, o então chefe da assessoria internacional do MEC, Alessandro Candeas, confirmava que o Ministério e o MRE estavam perfeitamente coordenados nessa matéria: “a educação não é um negócio, sujeito às regras de mercado. Trata-se de um serviço público, de direito do cidadão, e o MEC reconhece e elogia a atitude da delegação brasileira em Genebra". ${ }^{421}$

Com a saída de Tarso Genro do MEC, Fernando Haddad assumiu como Ministro, no período entre julho de 2005 e janeiro de 2012, mantendo a posição do seu antecessor em relação ao tema. Questionado sobre a educação como um bem público no final da Segunda Conferência Mundial sobre Ensino Superior, convocada em 2009 pela UNESCO, em Paris, assim respondeu:

\begin{abstract}
"Note-se que nesta conferência, a América Latina e o Caribe se mantiveram estreitamente unidos em defesa de princípios importantes para o futuro da educação superior no nosso continente. Um desses aspectos é este ponto de considerar o ensino superior como um bem público e um direito humano fundamental. Isso, naturalmente, parece uma frase simples, mas abrange toda uma filosofia do significado da educação, especialmente do ensino superior, para forjar uma identidade nacional, para forjar a identidade regional, a fim de proteger os bens culturais do nosso continente, para evitar comercialização da educação e da deterioração do ensino superior através das ações dos agentes oportunistas sem escrúpulos, para criar um sistema de acreditação que nos permita assegurar o intercâmbio de estudantes, professores, pessoal. Ou seja, que abrange uma boa agenda, e da cooperação."
\end{abstract}

Logo, a concepção do ensino superior como um bem público e um direito humano fundamental tem mantido a educação, aí incluída a educação superior, fora do escopo de acordos comerciais, preferenciais ou multilaterais, sobretudo desde o início do Governo Lula até o presente momento. Contrastando com um movimento contínuo de abertura de novas vagas no ensino superior pela iniciativa privada desde 1968, o Governo ampliou o investimento público nesse setor, retomando um processo

\footnotetext{
${ }^{421}$ JAPPE, Lívia. Brasil rejeita, na OMC, proposta de abertura do setor de educação.

422 BAIG, Jose. Fernando Haddad: o ensino superior é um bem público e um direito humano fundamental. In: Boletín Especial IESALC Informa n. 196 - Final da Conferência Mundial de Educação Superior. UNESCO: Instituto Internacional para a Educação Superior na América Latina e Caribe, $2009 . \quad$ Disponível em: http://www.unesco.org.ve/index.php?option=com content\&view=article\&id=603: ministro-deeducacion-de-brasil-la-educacion-superior-un-bien-publico-y-un-derecho-humanofundamental\&catid=19:internacional\&Itemid=153.
} 
de valorização das universidades públicas. Porém, também não foi capaz de evitar a contínua expansão do setor privado com fins lucrativos durante o mesmo período, com um amplo processo de fusões e aquisições e a abertura de capital de grupos educacionais brasileiros na Bolsa de Valores, refletindo a temperatura do mercado global que se construiu em torno da educação.

Assim, lembrado pelo entrevistador de que o ensino privado com fins lucrativos já era uma realidade na América Latina, sobretudo em nível superior, o então Ministro da Educação Fernando Haddad apontou as parcerias do setor público com o setor privado, em especial o PROUNI, com o intercâmbio de impostos por bolsas de estudo, e reiterou a necessidade de criação de um robusto sistema de avaliação, com implicações regulamentares, de forma a permitir "que o Estado intervenha e exclua do sistema as instituições que não se comprometam com a qualidade." 423

Nessa curta entrevista com Fernando Haddad são expostas as principais ideias que norteiam a concepção da educação superior patrocinada pelo Estado:

- compreender "o ensino superior como um bem público e um direito humano fundamental";

- "forjar uma identidade nacional";

- "forjar a identidade regional";

- "proteger os bens culturais do nosso continente";

- "evitar a comercialização da educação".

Todavia, o movimento contínuo de expansão da ensino privado, estimulado por vezes pelo próprio Estado, e a consolidação do setor privado com fins lucrativos deixam à ação estatal espaço para o desenho de parcerias com as instituições privadas, percebidas por alguns autores como uma demanda do próprio setor privado $^{424}$, e para a manutenção de um sistema de avaliação que possa excluir

\footnotetext{
${ }^{423}$ BAIG, Jose. Fernando Haddad: o ensino superior é um bem público e um direito humano fundamental.

${ }^{424}$ Ainda que reconheça amplamente o papel do PROUNI na democratização do acesso ao ensino superior, Carvalho (CARVALHO, Cristina Helena Almeida de. A política pública para a educação superior no Brasil (1995-2008): ruptura e/ou continuidade? p. 382) entende que "o governo Lula não abandonou o segmento privado. A continuidade nos instrumentos financeiros foi reforçada pela criação
} 
prestadores que não ofereçam educação de qualidade. Cabe assim, sob a perspectiva regulatória internacional, avaliar se a rede regulatória que vem sendo construída através de acordos regionais de comércio é capaz de constranger ainda mais a ação estatal nessa área, ou se os efeitos seriam mais simbólicos ao reconhecer explicitamente a educação como um bem comercializável negociado nos acordos em questão.

Fora das hipóteses que partem de uma leitura conceitual da educação superior como um direito humano e/ou um bem público, um dos resultados da pesquisa de $\operatorname{Verger}^{425}$ indica que a maior a presença do setor privado na educação superior de um país está associada a uma menor frequência no oferecimento de compromissos no setor educacional. Sob a perspectiva do Estado, o autor lê esse resultado como possivelmente relacionado ao fato de que os governos podem acreditar que a oferta de vagas doméstica, tanto pelo sistema público quanto pelo privado, é suficientemente ampla e, consequentemente, julgam desnecessário facilitar a entrada de provedores estrangeiros em seus sistemas educacionais através de acordos comerciais. Na perspectiva do setor privado, outra possibilidade refere-se ao seu poder e à sua habilidade de pressionar os governos a não liberalizarem a educação dentro do quadro do GATS ou de acordos preferenciais de comércio, evitando assim a concorrência com prestadores estrangeiros.

Não há no setor educacional privado com fins lucrativos brasileiro uma posição clara sobre a abertura do setor por meio de acordos comerciais. Se de um lado existe a tradicional demanda por uma menor intervenção do Estado na regulação da educação superior, de outro, tem-se o temor da concorrência com novas instituições estrangeiras de maior qualidade que possam se estabelecer no país. A declaração do então presidente da ABMES, em seminário sobre a internacionalização da educação

do PROUNI. A retomada da renúncia fiscal estendida ao segmento mercantil aplacou as constantes reivindicações da iniciativa privada por auxílio do Poder Público frente aos elevados índices de evasão, desistência e inadimplência de sua 'clientela'." No mesmo sentido, Almeida (ALMEIDA, Wilson Mesquita de. Ampliação do Acesso ao Ensino Superior Privado Lucrativo Brasileiro: um Estudo Sociológico com Bolsistas do Prouni na Cidade de São Paulo, p. 12) entende que "o desenho do PROUNI é visto como um mecanismo de financiamento público indireto, visando atacar o problema estrutural da estagnação desse setor privado lucrativo. Esse problema decorre de uma evolução histórica marcada pela explosão de vagas que levou à saturação e, juntamente com a inadimplência ligada aos valores das mensalidades - ainda bem distantes da folha salarial dos trabalhadores brasileiros -, provocaram vagas não preenchidas e decorrentes aumento dos custos e despesas da atividade empresarial que atua no ramo da educação superior, formando o terreno fértil para que se pensasse em soluções que desembocaram no Programa Universidade para Todos".

${ }^{425}$ VERGER, Antoni. Measuring educational liberalisation. A global analysis of GATS, p. 20. 
superior $^{426}$, em outubro de 2003, se situa exatamente entre uma posição que exalta a possibilidade da mais ampla liberdade possível de comércio em um futuro próximo e a preocupação com o equilíbrio desta com as políticas domésticas e o mercado educacional interno. ${ }^{427}$ No mesmo evento, por sua vez, Antônio Carbonari Netto, fundador do grupo Anhanguera Educacional e hoje membro do conselho de administração do grupo formado pela fusão com a Kroton Educacional, apontou que "nós, na condição de organismo, como mantenedoras e mantidas associadas à ABMES, não temos ainda uma posição firmada sobre esse assunto.",428

Carbonari Netto também destaca o papel que os mantenedores do ensino superior privado deveriam ter na definição das posições do país nos foros comerciais internacionais, na sua opinião, em detrimento do papel do MEC:

\begin{abstract}
"em seminário anterior, ouvi um secretário, também do Itamaraty, dizer que o MEC, há dois anos, foi consultado e que algumas comissões também foram consultadas. O que está em jogo é a internacionalização da mantença da educação." "E, se nós, mantenedores, nunca fomos consultados, espero que o Itamaraty, numa próxima rodada, ouça a parte interessada, constituída pelos mantenedores do ensino superior privado no Brasil. Porque, ouvir o MEC, ouvir funcionários públicos decidindo sobre o ensino privado, eu não aceito." "Portanto, o que está em discussão é a manutenção do setor privado, é a mantença, não é o Plano Nacional de Educação.",429
\end{abstract}

No entanto, ao mesmo tempo, entende ser função do Estado criar incentivos à organização educacional doméstica com vista a equiparar as instituições educacionais privadas às instituições estrangeiras, para que suportem a concorrência destas:

\footnotetext{
${ }^{426}$ Como já explicitado anteriormente, o autor prefere fazer a distinção entre os termos internacionalização" e "transnacionalização", no sentido de que o primeiro não acarreta necessariamente no segundo, enquanto a transnacionalização pressupõe a internacionalização da educação superior. No entanto, a adoção do termo "internacionalização" nesse trecho respeita o nome dado ao seminário e busca ser fiel à transcrição das falas na Revista da ABMES.

${ }^{427}$ FRANCO, Édson. Apresentação, Revista da Associação Brasileira de Mantenedoras de Ensino Superior, v. 22, n. 33, Abr. 2004, p. 4.

${ }^{428}$ CARBONARI NETTO, Antônio. In: Debates, Revista da Associação Brasileira de Mantenedoras de Ensino Superior, v. 22, n. 33, Abr. de 2004, p. 44.

${ }^{429}$ CARBONARI NETTO, Antônio. In: Debates, Revista da Associação Brasileira de Mantenedoras de Ensino Superior, p. 44.
} 
"seria o caso de começar um fundo de fomento à pesquisa, à melhoria do ensino, da qualidade, mas com dinheiro, com recursos... Seria política pública de investimento. Isto nos permitiria equiparar-nos aos níveis internacionais para concorrer." $\$ 30$

Como regra geral, a perspectiva de liberalização do comércio de serviços educacionais confronta dentro de um mesmo país dois grupos, cada um com sua própria cultura. Associações de estudantes e de professores, universidades públicas e universidades privadas tradicionais, ${ }^{431}$ particularmente as sem fins lucrativos, tendem à oposição ao processo de transnacionalização ou mesmo à própria ideia do comércio em educação, enquanto prestadores privados com fins lucrativos e o mundo dos negócios como um todo veem esse movimento de uma forma bastante positiva. ${ }^{432}$ As manifestações de representantes da ABMES e do setor privado lucrativo denotam um liberalismo à la carte. Existe um entusiasmo quanto à liberalização comercial como conceito, da mesma forma que o consequente engessamento regulatório do Estado e maior previsibilidade para os investidores são elementos que corresponderiam às demandas desses grupos no cenário doméstico. No entanto, a concorrência estrangeira é vista com receio, ainda que a ABMES venha se opondo a qualquer proposta que vise a impor limites à participação do capital estrangeiro na educação brasileira, muito em decorrência do aporte financeiro

\footnotetext{
${ }^{430}$ CARBONARI NETTO, Antônio. In: Debates, Revista da Associação Brasileira de Mantenedoras de Ensino Superior, p. 55.

${ }^{431}$ Nesse sentido, em uma declaração conjunta, associações representativas de universidades canadenses, europeias e norte-americanas - Association of Universities and Colleges of Canada, American Council on Education, European University Association e Council for Higher Education Accreditation -, reafirmaram a existência da educação superior voltada para o interesses público e não como mercadoria, o que já teria sido reconhecido pelos Estados Membros da OMC através da UNESCO e outros órgãos internacionais ou multilaterais, convenções e declarações, de modo que nada em acordos internacionais de comércio deveria restringir ou limitar a autoridade regulatória dos órgãos competentes nacionais (Joint Declaration on Higher Education and the General Agreement on Trade in Services, 28 Set. 2001. Disponível em: http://www.iau-hesd.net/sites/default/files/documents/2001 joint_declaration_on higher_education_and the general_agreement on trade in services_en.pdf).

Logo após, em abril de 2002, os reitores, presidentes e diretores de instituições de educação superior, e associações e outras autoridades acadêmicas reunidas na III Cúpula de Reitores de Universidades Públicas Ibéricas e Latino-Americanas também expressaram a preocupação com as políticas conduzidas na OMC e direcionadas ao comércio internacional de serviços educacionais. Parte do contínuo processo de drásticos cortes no financiamento público e promoção da globalização da educação privada, as propostas de liberalização do setor da educação superior trariam consequências desastrosas (Porto Alegre Declaration, 27 Abr. 2002. Disponível em: www.gatswatch.org/educationoutofgats/PortoAlegre.doc). Ambas declarações terminam por demandar dos respectivos governos a não consolidação de nenhum compromisso na matéria no âmbito das negociações que naquele momento transcorriam na OMC.

${ }^{432}$ LARSEN, Kurt; VINCENT-LANCRIN, Stéphan. International Trade in Educational Services: Good or Bad? Higher Education Management and Policy, v. 14, n. 3, 2002, p. 10.
} 
estrangeiro que têm ingressado no país nos últimos anos. Nesse ponto, tomando por base a fala de Carbonari Netto, se o MEC é instado a se afastar da formulação das posições nacionais sobre o tema - papel que seria do próprio setor privado -, o Estado é chamado a gerar as condições e, mais do que isso, financiar diretamente o fortalecimento dos grupos educacionais privados brasileiros, preparando-os para a concorrência estrangeira.

Trata-se de um discurso onde a resposta política seria proteger e promover "vencedores" (winners), quando, na verdade, para Kennedy ${ }^{433}$, o desafio político não seria encontrar recursos para derramar sobre esses grupos na esperança de que tornem o país competitivo. Não são mais as nações que competem e, geralmente, esses grupos são capazes de tomar conta de si mesmos, sob pena de gerar uma espiral na qual os "vencedores" consolidam uma política territorial cada vez mais fraca e uma ordem econômica cada vez mais dominante.

Nesse sentido, também quando voltadas às posturas dos negociadores, as entrevistas realizadas por Verger mostram que o tema "educação", em si, tem um perfil muito baixo no discurso dos atores que conduzem as negociações sobre serviços:

\begin{abstract}
"quando perguntados sobre questões educacionais, os negociadores não demonstraram muita consciência quanto ao debate apaixonado sobre o GATS e seus efeitos na educação iniciadas pela comunidade internacional de educação, e eles nunca se referem a fontes de educação quando se discute o assunto. Os negociadores têm suas próprias opiniões sobre a área, que, como mencionado, normalmente enfatizam os potenciais efeitos positivos do GATS para a educação. Na verdade, parece que eles aplicam à educação os mesmos quadros de significados que se aplicariam à análise de qualquer outro serviço ou mercadoria.",434
\end{abstract}

\footnotetext{
${ }^{433}$ KENNEDY, David. Law and the Political Economy of the World, Leiden Journal of International Law, v.26, 2013, p. 11.

${ }^{434}$ Tradução direta do inglês: "when asked about education issues, trade negotiators did not demonstrate much of an awareness of the passionate debate on GATS and its effects on education initiated by the international education community, and they never referred to education sources when discussing the topic. Negotiators have their own opinions on the area, which, as mentioned, normally emphasizes the potential positive effects of GATS for education. In fact, it seems that they apply to education the same meaning frames that they would apply to the analysis of any other service or commodity." (VERGER, Antoni. The Merchants of Education: Global Politics and the Uneven Education Liberalization Process within the WTO, p. 11-22)
} 
Considerando que a educação foi conduzida ao regime do comércio internacional, apropriada por uma lógica que não a sua, é natural que os setores educacional e comercial ainda tenham a sua própria dinâmica, com esferas de influência e jargões técnicos muito distantes um do outro, e não raro atribuindo às mesmas palavras significados diferentes. ${ }^{435} \mathrm{O}$ discurso contrário ao GATS é enquadrado a partir do compromisso político com as funções tradicionais da educação e as formas pelas quais elas deve ser oferecida, em geral sob o controle do Estado. De outro lado, tem-se o setor comercial constituído pelas premissas da teoria liberal de comércio e da vantagem comparativa, de modo a avaliar os efeitos da liberalização sobre a educação a partir das mesmas premissas, sem reconhecer as particularidades de setores muito distintos. Assim, hipóteses sobre concorrência, eficiência do mercado e satisfação do cliente dominam a definição de interesses na matéria e deixam em segundo plano potenciais problemas decorrentes de acordos comerciais. ${ }^{436}$

A emergência do GATS, ainda na década de 90, e o fluxo de acordos preferenciais de comércio ocorrido a seguir, obrigam os dois segmentos a interagirem, mesmo que com abordagens e racionalidades bastante distintas. Nesse processo, quanto mais organizado e conhecedor das negociações, maior a capacidade do setor educacional de definir a posição do país sob uma perspectiva favorável ao regulador. Como visto, até então no Brasil, isso parece ter sido feito com sucesso no âmbito das solicitações e ofertas no GATS, articulando diretamente com os negociadores comerciais do país em Genebra. Sem essa abordagem, crescem as chances dos serviços educacionais serem inseridos em um trade-off, unicamente sob uma racionalidade econômica.

\footnotetext{
${ }^{435}$ VERGER, Antoni. Making sense of the GATS debate: semiotic analysis of the conflicting ideas on the education/free-trade relationship, International Studies in Sociology of Education, v.21, n.3, 2010, p. 247.

${ }^{436}$ VERGER, Antoni. Making sense of the GATS debate: semiotic analysis of the conflicting ideas on the education/free-trade relationship, p. 248.
} 


\section{OS ACORDOS PREFERENCIAIS DE COMÉRCIO E A LIBERALIZAÇÃO DO COMÉRCIO DE SERVIÇOS DE EDUCAÇÃO SUPERIOR}

Com avanços considerados insuficientes nas negociações de liberalização do comércio de serviços no sistema GATS/OMC, os países que se destacam por uma agenda ofensiva nesta matéria voltaram-se aos acordos preferenciais de comércio para fazer avançar as questões regulatórias que não haviam encontrado guarida até então na esfera multilateral, garantindo acesso a mercados em setores de serviços ainda não consolidados junto ao GATS, principalmente por parte dos países em desenvolvimento. O sucesso de tal estratégia varia de acordo com os parceiros comerciais signatários dos respectivos acordos, bem como do modelo de liberalização adotado pelas partes. Ainda que, como referido anteriormente, os modelos de lista positiva - de inspiração proveniente do GATS - e os modelos de lista negativa - de inspiração proveniente do NAFTA - tenham, em teoria, cada vez mais uma base regulatória mais próxima uma da outra e possam gerar níveis de liberalização semelhantes, os últimos tendem a envolver um número muito superior de setores de serviços e também a constranger de forma muito mais significativa a capacidade posterior do Estado de intervenção regulatória, inclusive em setores sensíveis.

Assim, se no GATS/OMC os serviços educacionais foram um dos setores com o menor número de compromissos de liberalização, a situação se altera no quadro dos acordos preferenciais de comércio com a inclusão e/ou aprofundamento dos compromissos na maior parte dos acordos, em especial nos de natureza Norte-Sul. Esse contexto faz com que a análise dos compromissos preferenciais consolidados e das reservas/limitações inseridas permita estabelecer com maior acerto um parâmetro do nível de liberalização comercial da educação superior sob a perspectiva do direito do comércio internacional, passível de ser comparado com os marcos regulatórios educacionais domésticos.

Ao mesmo tempo, a rede de acordos assinados entre os principais países com interesses exportadores na matéria, muitas vezes entre si, torna possível analisar semelhanças e diferenças entre suas estratégias de liberalização, avaliando a existência ou não de um processo de governança na comercialização da educação superior com um determinado padrão regulatório. 


\subsection{Pressupostos metodológicos para a análise}

\subsubsection{Países escolhidos}

Como uma alternativa aos compromissos assumidos no GATS para mapear os novos passos regulatórios em educação superior, foram priorizados os acordos de livre-comércio já assinados, posteriores ao ano 2000, e excluídos os acordos de integração econômica puros, associações econômicas e acordos de comércio que envolvam países de menor desenvolvimento relativo. ${ }^{437} \mathrm{~A}$ seleção procura equilibrar a diversidade de países signatários de acordo com a importância destes no comércio internacional de educação, além de contemplar a ideia de rede, com linhas de continuidade nas estratégias dos países com acordos entre si e com um grupo comum de parceiros comerciais.

Austrália, Estados Unidos e Reino Unido são os principais exportadores de estabelecimentos de ensino superior. ${ }^{438} \mathrm{O}$ Chile, por sua vez, dentro da América Latina, é um dos países mais ativos na assinatura de acordos de livre comércio, com o setor educacional incluído nesta estratégia. De outro lado, em um cenário no qual se espera que a Ásia represente $70 \%$ da demanda global por educação superior internacional, ${ }^{439}$ os países exportadores, de cultura anglo-saxã, foram seguidos por outros países menores, em especial Cingapura, que, de significativos importadores de educação superior, passam a promover seus serviços educacionais nos mercados regional e global, com vista a se tornarem polos exportadores de ensino superior. ${ }^{440}$ Por fim, Estados de enorme população e principais países em desenvolvimento parceiros do Brasil, tanto China quanto Índia possuem uma

\footnotetext{
${ }^{437}$ Critério apresentado em TASQUETTO, Lucas da Silva; RORIZ, João Henrique Ribeiro. Comércio e Regras sobre Propriedade Intelectual nos Acordos Preferenciais de Comércio. In: OLIVEIRA, Ivan Tiago Machado; BADIN, Michelle Ratton Sanchez. Tendências Regulatórias nos Acordos Preferenciais de Comércio no Século XXI: os casos de Estados Unidos, União Europeia, China e Índia. Brasília: IPEA, 2013, p. 145-167. Excepcionalmente, foram considerados os acordos assinados pela China com a ASEAN, e por Chile e Cingapura com a EFTA.

${ }^{438}$ GROSBON, Sophie. Le droit à l'enseignement supérieur et la liberalisation international du commerce des services, p. 10; e VANDUZER, J. Anthony. Navigating between the Poles: Unpacking the Debate on the Implications for Development of GATS Obligations Relating to Health and Education Services, p. 189.

${ }^{439}$ TOH, Mun-Heng. Internationalization of Tertiary Education Services in Singapore, p. 7.

${ }^{440}$ VLK, Ales. Higher Education and GATS: Regulatory Consequences and Stakeholders' Responses. Tese (Doutorado em Educação). Universidade de Twente (Universiteit Twente), 2006, p. 33.
} 
demanda doméstica não suprida pelo poder público e interesses exportadores em educação superior, com acordos comerciais que procuram atender a esta dupla preocupação.

Enquanto Austrália e Estados Unidos são demandantes tradicionais por uma maior abertura no setor educacional desde as primeiras negociações do GATS em menor medida a União Europeia, em decorrência da heterogeneidade de posições no interior do bloco -, e o Chile parece se engajar na abertura do setor no contexto de uma ampla liberalização comercial em geral, Cingapura, China e Índia, no decorrer dos anos, assumem nos acordos preferenciais de comércio uma postura distinta da adotada em um primeiro momento nas negociações multilaterais. Nesses países, em resposta a estratégias específicas e/ou demandas domésticas, os serviços educacionais tem sido paulatinamente incluídos no escopo de seus acordos.

Nos anos recentes, uma das grandes destinações para estudantes internacionais, Cingapura participou de um contexto de mudanças estruturais e políticas onde alguns países da ASEAN - com destaque também para a Malásia reestruturaram suas universidades públicas, concederam permissão para o estabelecimento de universidades privadas onde antes elas não existiam, e, em alguns casos, concederam permissão para que instituições estrangeiras oferecessem educação superior. ${ }^{441}$ Em particular, dentro de um projeto para a diversificação e crescimento da economia, o país identificou a educação como um dos setores promissores para ser desenvolvido. ${ }^{442}$ Assim, a partir da década de 90, Cingapura procurou atrair universidades internacionais de elite para o seu território, tanto através de programas conjuntos com universidades locais quanto por meio do estabelecimento de campi dessas instituições estrangeiras. O plano era atrair mais de 150.000 estudantes estrangeiros até $2015,{ }^{443}$ majoritariamente pagantes de matrículas plenas e executivos de empresas residentes em Cingapura para treinamento corporativo. ${ }^{444}$ Até o final de 2011, mais de 31 universidades estrangeiras - entre elas: Duke, Universidade de

\footnotetext{
${ }^{441}$ ORGANIZAÇÃO MUNDIAL DO COMÉRCIO. Conselho sobre Comércio de Serviços. Education services: background Note by the Secretariat, p. 6.

${ }^{442} \mathrm{TOH}$, Mun-Heng. Internationalization of Tertiary Education Services in Singapore, p. 6; e THAM, Siew Yean. Trade in Higher Education Services in Malaysia: Key Policy Challenges, p. 115.

${ }_{443}$ RAYCHAUDHURI, Ajitava; DE, Prabir. Barriers to Trade in Higher Education Services Empirical Evidence from Asia-Pacific Countries, p. 71.

${ }^{444}$ Parte central dessa estratégia é o convite para universidades estrangeiras estabelecerem campus em ambos os países, como forma de gerar mais oportunidades educacionais para seus cidadãos, mas sobretudo para aumentar a capacidade de atração de investimentos estrangeiros e pesquisa de alta tecnologia (Lim e Saner, p. 2).
} 
Chicago, Universidade de Cornell e Universidade de Nova Iorque - estavam trabalhando em programas conjuntos, desde a graduação até o doutorado, em áreas como administração de negócios, direito, economia, artes, ciências médicas e subdisciplinas da engenharia. ${ }^{445}$

Todavia, no desenvolvimento de Cingapura como um polo educacional, os acordos preferenciais desempenharam um papel de facilitadores, mas não foram determinantes para o sucesso da estratégia. Primeiro, os planos do país dependeram em grande parte da sua habilidade em oferecer um amplo espectro de opções educacionais de qualidade, oferecidas por instituições de reconhecida qualidade, aliada à fácil acessibilidade geográfica do território, reputação e boa gestão financeira. ${ }^{446} \mathrm{Com}$ efeito, as reformas foram, antes de tudo, reformas domésticas, posteriormente replicadas nos compromissos oferecidos pelo país nos acordos comerciais e nas ofertas multilaterais. Os acordos comerciais, então, ajudaram a aumentar o conhecimento das oportunidades de investimento em Cingapura, pavimentaram o caminho para investimentos conjuntos, e também foram usados como plataforma para aumentar a interação e as trocas entre as instituições educacionais dos países partes dos acordos. ${ }^{447}$

Por sua vez, na China e na Índia, o ensino superior privado também segue uma tendência de expansão, correspondendo já a uma parte significativa do sistema educacional. Assim como no Brasil, o crescimento do investimento privado é também uma resposta à incapacidade do setor público de providenciar os recursos financeiros necessários para garantir o acesso demandado pelas populações crescentes. Do mesmo modo, a tendência é de que o setor privado continue a funcionar principalmente na parte inferior da hierarquia acadêmica, majoritariamente vocacional em sua natureza e destinado a absorver a demanda. Logo,

"ambos os países enfrentam um desafio significativo para criar um
quadro regulatório estável e transparente que forneça tanto regras
básicas para o setor privado quanto procedimentos para a garantia da
qualidade e responsabilidade financeira. Principalmente questões como
o papel do setor com fins lucrativos e se os prestadores privados

${ }^{445}$ TOH, Mun-Heng. Internationalization of Tertiary Education Services in Singapore, p. 11.
${ }^{446}$ TOH, Mun-Heng. Internationalization of Tertiary Education Services in Singapore, p. 22.
${ }^{447}$ TOH, Mun-Heng. Internationalization of Tertiary Education Services in Singapore, p. 22. 
estrangeiros podem se ligar com universidades e faculdades privadas locais permanecem sem resposta." 448

Nesses países, questões que dizem respeito à regulação dos investimentos estrangeiros em educação permanecem controversos: papel das redes de campi independentes, propriedade de instituições, papel do setor privado com fins lucrativos, garantia de qualidade para instituições estrangeiras, papel dos programas franqueados de graduação no exterior, entre outros. O processo de regulação e implementação das normas é particularmente complexo para China e Índia em decorrência das diferentes jurisdições dos governos central e provincial, bem como das mudanças de perspectiva entre os formuladores de políticas. Eles procuram manter o controle sobre as instituições e programas estrangeiros em seus territórios enquanto dão boas vindas ao envolvimento internacional. ${ }^{449}$ Por outro lado, ao mesmo tempo, seus próprios setores privados educacionais também procuram se expandir no exterior. $^{450}$

Os acordos preferenciais de Índia e China, então, parecem consolidar o ingresso de investidores estrangeiros na educação e reagir aos interesses domésticos de um setor que se vê em condições de competir internacionalmente. Assim, quase todos os acordos envolvendo a Índia, tanto com países desenvolvidos quanto com países em desenvolvimento, contêm capítulos sobre uma variedade de setores, possivelmente refletindo a competitividade do país em serviços e seu interesse em alavancar seus acordos preferenciais para explorar oportunidades comerciais e colaborativas em uma variedade de setores de serviços. ${ }^{451}$ Comparados com os compromissos do país junto ao GATS, os compromissos da Índia nos seus acordos de

\footnotetext{
${ }^{448}$ Tradução livre do inglês: "Both countries face a significant challenge to create a stable and transparent regulatory framework that provides both ground rules for the private sector and procedures for quality assurance and financial accountability. Questions such as the role of the for-profit sector and whether foreign private providers can link with local private universities and colleges remain mainly unanswered" (ALTBACH, Philip G. The Giants Awake: The Present and Future of Higher Education Systems in China and India. In: OECD. Higher Education to 2030, Volume 2: Globalisation. OECD, Centre for Educational Research and Innovation: 2009, p. 198)

${ }^{449}$ ALTBACH, Philip G. The Giants Awake: The Present and Future of Higher Education Systems in China and India, p. 189.

${ }^{450}$ RAYCHAUDHURI, Ajitava; DE, Prabir. Barriers to Trade in Higher Education Services Empirical Evidence from Asia-Pacific Countries, p. 71.

${ }^{451}$ CHANDA, Rupa. Mapping the Universe of Services Disciplines in Asian PTAs. NCCR Trade Regulation Working Paper No 2011/33, Mai. 2011, p. 14. Disponível em: http://www.nccrtrade.org/fileadmin/user_upload/nccrtrade.ch/wp2/people/WPed5ed\%20Mapping\%20the\%20Universe\%20of\%20Services\%20Disciplines\% 20in $\% 20$ Asian $\% 20$ PTAs $\% 202$ _-reply $\% 20$ may.pdf.
} 
comércio, principalmente com Cingapura e Coreia do Sul, representaram um aumento significativo de compromissos sem restrições nos modos de serviços 1,2 e 3. Vários setores que não tinham sido consolidados no GATS, entre eles a educação, foram inseridos nesses acordos, sem nenhuma restrição nos três modos. ${ }^{452}$ Em particular no modo 3 (presença comercial), a Índia se concentra em setores de serviços como o hoteleiro, serviços financeiros, saúde e educação, de interesse dos grandes grupos exportadores indianos. ${ }^{453}$

O mesmo padrão GATS-plus também se dá nos acordos assinados pela China. Não só são incluídos setores de serviços antes não consolidados na OMC, mas também são estendidas as obrigações relacionadas ao comércio de serviços, com medidas de transparência, políticas de concorrência e garantias de maior acesso a mercados. Essa política abrange também o setor educacional, com significativos compromissos de abertura de mercado e de aquisição de serviços educacionais, no caso do acordo com a Nova Zelândia, por exemplo. ${ }^{454}$

\subsubsection{Barreiras comerciais}

Em geral, as barreiras ao comércio de serviços não são tarifas, mas típicas barreiras regulatórias. A racionalidade econômica subjacente às reformas regulatórias é de que a remoção das barreiras ao comércio de serviços resultaria em menores preços, maior qualidade e grande concorrência entre os prestadores. ${ }^{455}$ Assim, em especial nos modos 1 e 3, essas são medidas à disposição do regulador doméstico para a regulamentação do ensino superior no país, que, no entanto, quando conduzidas para a lógica de acordos comerciais, podem ser consideradas barreiras ao livre comércio que devem ser eliminadas.

\footnotetext{
${ }^{452}$ CHANDA, Rupa. Mapping the Universe of Services Disciplines in Asian PTAs, p. 55.

${ }^{453}$ NAG, Biswajit; CHAISSE, Julien; CHAKRABORTY, Debashis. Mapping the Universe of Services Disciplines in PTAs: The Indian Contribution. Pacific Economic Cooperation Council and the Asian Development Bank Institute Inaugural Conference: Strategies to enhance Competitiveness and Facilitate Regional Trade and Investment in Services, p. 21. Disponível em: http://www.pecc.org/resources/doc_view/1704-mapping-the-universe-of-services-disciplines-in-ptasthe-indian-contribution-paper.

${ }^{454}$ SCHOTT, Jeffrey J.; LEE, Minsoo; MUIR, Julia. Prospects for Services Trade Negotiations. Asian Development Bank Economics Working Paper Series \#319, Nov. 2012, p. 8-9. Disponível em: http://papers.ssrn.com/sol3/papers.cfm?abstract_id=2174129.

${ }^{455}$ RAYCHAUDHURI, Ajitava; DE, Prabir. Barriers to Trade in Higher Education Services Empirical Evidence from Asia-Pacific Countries, p. 76.
} 
Sendo assim, a forma pela qual se concede acesso privilegiado aos mercados de serviços dependerá dos instrumentos de proteção que estão em uso. Ao impor restrições quantitativas à prestação de serviços ou sobre o número de prestadores de serviços, um país pode alocar uma maior proporção da cota para uma fonte preferida. Outro meio comum de restringir acesso a mercados de serviços, que se presta por si mesmo a um tratamento preferencial, é impor condições à propriedade estrangeira, o tipo de pessoa jurídica permitida, e direitos das subsidiárias. A maior parte dos países que recebem investimentos estrangeiros confere tratamento nacional aos investidores estrangeiros após o seu estabelecimento, mas o tratamento nacional raramente se aplica antes disso. Assim, esses países são capazes de impor requisitos de desempenho a prestadores estrangeiros de serviços. Preferências também podem ser garantidas por meio de impostos e subsídios, na medida em que prestadores estrangeiros podem estar sujeitos a tributos diferentes dos prestadores domésticos. Ainda, os países podem e de fato impõem a prestadores estrangeiros requisitos de qualificação e licenciamento, que podem ser mais onerosos do que o necessário para satisfazer objetivos legítimos de políticas públicas. ${ }^{456}$ Essas exigências podem ser facilmente dispensadas para membros de um acordo preferencial de comércio, conforme as negociações e os interesses dos setores domésticos de serviços.

Tal como em outros setores, essas medidas gerais se desdobram em uma série de restrições que são colocadas ao comércio de serviços educacionais. As barreiras à prestação de serviços por meio do modo 1 podem envolver restrições sobre a transmissão eletrônica de materiais para os cursos, com novas barreiras - eletrônicas ou jurídicas - para o uso da internet para serviços educacionais, restrições para o uso e/ou importação de materiais educacionais, o não reconhecimento de qualificações obtidas através de ensino à distância, cotas ou provas de necessidade econômica restringindo o número de prestadores; restrições sobre pagamentos e transferências de fundos ao exterior, exigências locais discriminatórias para autorização ou licenciamento, restrições sobre os tipos de cursos que podem ser oferecidos, e medidas exigindo o uso de parceiros locais ou a presença física da instituição estrangeira. $^{457}$

\footnotetext{
${ }^{456}$ MATOO, Aaditya; SAUVÉ, Pierre. Services, p. 237.

${ }^{457}$ LIM, Aik Hoe; SANER, Raymond. Rethinking Trade in Education Services: A Wake-Up Call for Trade Negotiators, p. 1021.
} 
No que tange ao modo 2 de serviços, as restrições diretas ao fluxo de estudantes para o exterior em geral concentram-se nas exigências e custos para o obtenção de visto, e nos controles cambiais. Indiretamente, também são impostas dificuldades para o reconhecimento de qualificações anteriores obtidas em outros países, cotas sobre o número de estudantes estrangeiros, restrições sobre a possibilidade de trabalhar paralelamente ao estudo, e restrições ao reconhecimento de novas qualificações por outros países. ${ }^{458}$

Quanto às restrições sobre o movimento de pessoas físicas, modo 4, estas estão geralmente relacionadas às regras de imigração e exigências de nacionalidade ou de residência. No entanto, outras barreiras podem se somar a essas, principalmente em torno de provas de necessidade, reconhecimento de credenciais, exigências mínimas desproporcionalmente altas para a contratação local, dificuldades para obter autorização para entrada e saída do país, cotas sobre o número de funcionários temporários, alto custo para a repatriação dos salários, regras trabalhistas, e restrições sobre o uso e/ou importação de materiais educacionais para serem usados pelo professor ou pesquisador. ${ }^{459}$

Comparativamente com os outros modos de serviços, o modo 3 parece atrair um número maior de barreiras identificadas, com restrições sobre o estabelecimento e operação da presença comercial de companhias estrangeiras centradas nos seguintes eixos:

Tabela 02 - Barreiras Comerciais

\begin{tabular}{|l|l|}
\hline \multicolumn{1}{|c|}{ Acesso a mercados } & \multicolumn{1}{c|}{ Tratamento nacional } \\
\hline Número de prestadores de serviços & Medidas relacionadas a impostos \\
\hline Valor total de ativos e transações & Subsídios e subvenções \\
\hline Número de operações & Outras medidas financeiras \\
\hline Número de pessoas físicas & Requisitos de nacionalidade \\
\hline Tipos de pessoa jurídica & Requisitos de residência \\
\hline Participação de capital estrangeiro & Licenciamento, normas e qualificações \\
\hline & Requisitos de registro \\
\hline
\end{tabular}

\footnotetext{
${ }^{458}$ KNIGHT, Jane. Trade in Higher Education Services: The Implications of GATS. Report for the observatory on borderless higher education, Mar. 2002, p. 13.

${ }^{459}$ KNIGHT, Jane. Trade in Higher Education Services: The Implications of GATS, p. 14; e TOH, Mun-Heng. Internationalization of Tertiary Education Services in Singapore, p. 21.
} 


\begin{tabular}{|l|l|}
\hline & Requisitos de autorização \\
\hline & Requisitos de desempenho \\
\hline & Requisitos de transferência de tecnologia \\
\hline & Conteúdo local e requisitos de treinamento \\
\hline & Propriedade de imóveis \\
\hline
\end{tabular}

Elaboração do autor a partir dos dados consolidados no documento da OMC (Education services: background note by the Secretariat, p. 22-23).

Quanto aos serviços educacionais, esses pontos podem aparecer sob as seguintes formas: prova de necessidade econômica sobre fornecedores de serviços educacionais; limites sobre a participação de capital estrangeiro e sobre os tipos de pessoa jurídica; medidas que exigem o uso de parceiros locais, dificuldades para a aprovação ou proibição de empreendimentos conjuntos (joint ventures), requisitos para autorização ou licenciamento; tratamento fiscal discriminatório, taxas sobre a repatriação dos lucros das companhias educacionais, restrições sobre o estabelecimento de pessoa jurídica com fins lucrativos - em alguns casos, instituições privadas de ensino superior só podem ser constituídas como entidades sem fins lucrativos; restrições sobre a concessão por instituições privadas de títulos reconhecidos pelo Estado, sobre disciplinas/áreas/programas considerados contrários a determinados interesses nacionais, sobre os alunos que podem ser inscritos - por exemplo, instituições estrangeiras só podem receber alunos estrangeiros; restrições sobre o recrutamento de professores e pesquisadores estrangeiros, exigências de nacionalidade no corpo docente, não reconhecimento de títulos concedidos no exterior; subsídios para educação superior concedidos de uma forma não clara e transparente; sistemas de bolsas ou subsídios para centros educacionais específicos os alunos matriculados em instituições estrangeiras não se qualificam para benefícios do governo ou assistência financeira -, restrições para instituições estrangeiras acessarem fundos do governo concedidos a instituições domésticas, e limites para aquisição de bens imóveis. ${ }^{460}$

\footnotetext{
${ }^{460}$ Diferentes trabalhos delinearam listas sobre possíveis barreiras comerciais em relação ao modo 3 (presença comercial) de serviços: OMC (Education services: background note by the Secretariat, p. 8), Knight (Trade in Higher Education Services: The Implications of GATS, p. 13-14), Robertson, Bonal e Dale (GATS and the Education Service Industry: The Politics of Scale and Global Reterritorialization, p. 487), Cottier, Breining-Kaufmann e Kennett (Liberalisation of Higher Education Services in Switzerland: The Impact of the General Agreement on Trade in Services (GATS), p. 83), Verger (The constitution of a new global regime: Higher education in the GATS/WTO framework, p. 114),
} 


\subsubsection{Metodologia de análise dos acordos}

No universo dos atores selecionados - Austrália, Cingapura, Chile, China, Estados Unidos, Índia e União Europeia - estão presentes não só acordos comumente assinados entre si, mas também com um grupo semelhante de parceiros comerciais, como se verifica nas tabelas que seguem. Assim, ainda que a análise sistemática dos acordos se dê somente nos referidos países, a rede de acordos por eles estabelecida faz com que instrumentos de outros países com interesses exportadores em educação superior - Japão, Malásia e Nova Zelândia - e ativos em acordos de livre comércio - Colômbia, Coreia do Sul e Peru - também sejam contemplados.

Tabela 03 - Total de acordos preferenciais de comércio analisados

\begin{tabular}{|c|c|c|c|c|c|c|c|c|c|c|c|c|c|c|c|c|c|c|c|c|c|c|c|c|}
\hline & 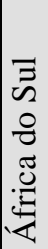 & 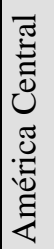 & 䓛 & 茎 & $\stackrel{\frac{0}{二}}{\stackrel{\Xi}{U}}$ & $\underset{\Xi}{\stackrel{\Xi}{\Xi}}$ & 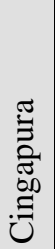 & $\begin{array}{l}. \frac{\pi}{0} \\
\frac{0}{0} \\
\frac{0}{0} \\
0 \\
0\end{array}$ & 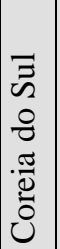 & $\begin{array}{l}\frac{\pi}{\tilde{0}} \\
\frac{\pi}{\pi} \\
\tilde{0} \\
0\end{array}$ & 岕 & 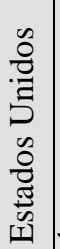 & $\stackrel{\widetilde{\pi}}{\stackrel{\Im}{\Xi}}$ & 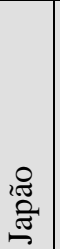 & 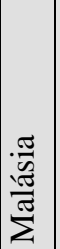 & 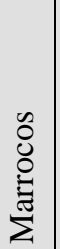 & 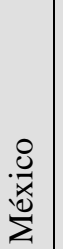 & 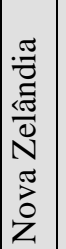 & 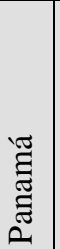 & 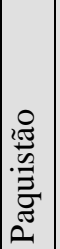 & ᄅ & 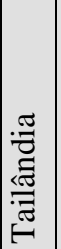 & $\underset{\Xi}{\stackrel{\sigma}{\Xi}}$ & 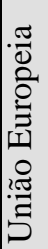 \\
\hline Austrália & & & & & $X$ & & $\mathrm{X}$ & & & & & $\mathrm{X}$ & & & $\mathrm{X}$ & & & & & & & $\mathrm{X}$ & & \\
\hline Chile & & & & $X$ & & $X$ & & $X$ & $X$ & & $X$ & $X$ & $X$ & $X$ & $X$ & & & & $\mathrm{X}$ & & $\mathrm{X}$ & & $\mathrm{X}$ & $X$ \\
\hline China & & & $\mathrm{X}$ & & $X$ & & $X$ & & & & & & & & & & & $\mathrm{X}$ & & $\mathrm{X}$ & $\mathrm{X}$ & & & \\
\hline Cingapura & & & & $X$ & & $\mathrm{X}$ & & & $\mathrm{X}$ & $\mathrm{X}$ & $\mathrm{X}$ & $\mathrm{X}$ & $\mathrm{X}$ & $\mathrm{X}$ & & & & $\mathrm{X}$ & & & $\mathrm{X}$ & & & \\
\hline Estados Unidos & & & & $X$ & $\mathrm{X}$ & & $X$ & $\mathrm{X}$ & & & & & & & & $X$ & & & & & $X$ & & & \\
\hline Índia & & & & & $X$ & & $X$ & & $X$ & & & & & $\mathrm{X}$ & $X$ & & & & & & & & & \\
\hline União Europeia & $\mathrm{X}$ & $X$ & & & $X$ & & & $\mathrm{X}$ & $\mathrm{X}$ & & & & & & & & & & & & $\mathrm{X}$ & & & \\
\hline
\end{tabular}

Elaboração pelo autor.

Cattaneo, Engman, Sáez e Stern (Assessing the potential of services trade in developing countries: an overview, p. 14), Matto e Sauvé (Services, p. 237), Lim e Saner (Rethinking Trade in Education Services: A Wake-Up Call for Trade Negotiators, p. 1023) e Toh (Internationalization of Tertiary Education Services in Singapore, p. 21). 
Tabela 04 - Acordos preferenciais de comércio entre os atores analisados

\begin{tabular}{|c|c|c|c|c|c|c|c|}
\hline & 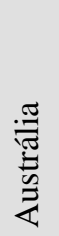 & 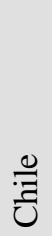 & 节 & 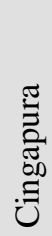 & 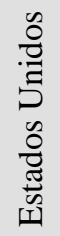 & 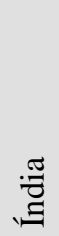 & 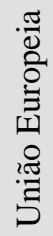 \\
\hline Austrália & & $\mathrm{X}$ & & $\mathrm{X}$ & $\mathrm{X}$ & & \\
\hline Chile & $\mathrm{X}$ & & $\mathrm{X}$ & & $\mathrm{X}$ & $\mathrm{X}$ & $\mathrm{X}$ \\
\hline China & & $\mathrm{X}$ & & $\mathrm{X}$ & & & \\
\hline Cingapura & $\mathrm{X}$ & & $\mathrm{X}$ & & $\mathrm{X}$ & $\mathrm{X}$ & \\
\hline Estados Unidos & $\mathrm{X}$ & $\mathrm{X}$ & & $\mathrm{X}$ & & & \\
\hline Índia & & $\mathrm{X}$ & & $\mathrm{X}$ & & & \\
\hline União Europeia & & $\mathrm{X}$ & & & & & \\
\hline
\end{tabular}

Elaboração pelo autor.

Ainda antes de abordar os compromissos e limitações sobre serviços educacionais, de forma geral, a ideia de uma rede de acordos preferenciais de comércio parece se confirmar de imediato, dada a repetição dos principais parceiros comerciais entre os diferentes países considerados. Nesse universo de acordos, com 7 parceiros possíveis, o Peru tem 5 acordos em vigor; a Coreia do Sul tem 4; Colômbia, Japão e Malásia tem 3, e a Nova Zelândia tem 2. Sob outro recorte, considerando somente as estratégias comerciais entre os 7 países escolhidos, entre 6 parceiros possíveis, o Chile tem 5 acordos em vigor - com todos os países do grupo, salvo Cingapura -, Cingapura tem 4; Austrália e Estados Unidos tem 3, ambos ainda sem acordos com as outras grandes economias consideradas - China, Índia e União Europeia -; China e Índia tem 2 acordos somente, ambos com os mesmos países Chile e Cingapura -; e a União Europeia tem somente uma acordo, com o Chile. ${ }^{461}$

Tomados um a um os acordos preferenciais de comércio selecionados, a partir da análise dos seus capítulos de serviços, é apontada a presença ou não de

\footnotetext{
${ }^{461}$ Para uma comparação entre a postura da União Europeia e dos Estados Unidos, de um lado, e da China e da Índia, de outro, sobre os acordos preferenciais de comércio em geral, ver BADIN, Michelle Ratton Sanchez. Compromissos assumidos por grandes e médias economias em acordos preferenciais de comércio: o contraponto entre União Europeia e Estados Unidos e China e Índia. In: OLIVEIRA, Ivan Tiago Machado; BADIN, Michelle Ratton Sanchez. Tendências Regulatórias nos Acordos Preferenciais de Comércio no Século XXI: os casos de Estados Unidos, União Europeia, China e Índia. Brasília: IPEA, 2013, p. 41-69.
} 
dispositivos referentes às principais disciplinas - tratamento nacional, tratamento de nação mais favorecida, acesso a mercados, regulação doméstica, compras governamentais e subsídios -, o modelo de lista adotado, e a forma como se dá o tratamento do investimento em serviços - como modo 3 (presença comercial) no próprio capítulo de serviços, como investimento no capítulo específico sobre investimentos ou regulado por ambos. Nesses dois últimos casos, quando sob a cobertura do capítulo de investimentos, são apontadas as disciplinas passíveis de serem aplicadas aos investimentos em serviços.

Entre os quatro modos de serviços utilizados como referência pelos acordos comerciais, o foco está na análise dos compromissos e/ou reservas/limitações que dizem respeito ao modo 3 de serviços (presença comercial), envolvendo em especial o estabelecimento de instituições estrangeiras de ensino superior e a formação de empreendimentos conjuntos (joint ventures) entre prestadores domésticos e prestadores estrangeiros. Naturalmente, compromissos e/ou reservas/limitações horizontais, que incidem sobre todos os setores e subsetores incluídos nos cronogramas de liberalização, serão considerados na medida do quanto se julgue serem passíveis de impactarem a regulamentação da educação superior. Do mesmo modo, compromissos e/ou reservas/limitações horizontais de terceiros países, ainda que em princípio fora do âmbito de abrangência da pesquisa, quando relevantes serão também estudados. No caso de acordos celebrados entre os países inicialmente selecionados, os compromissos e/ou reservas/limitações serão apresentados separadamente, nas partes que dizem respeito respectivamente a cada país.

As diferenças entre os modelos de lista positiva e de lista negativa impõem também abordagens distintas. Como nos acordos que seguem o padrão de lista positiva do GATS determinados setores de serviços só são liberalizados se deliberadamente inseridos nos cronogramas de compromissos das partes, cabe analisar, se incluídos, os eventuais compromissos específicos em matéria de educação superior e a extensão dos mesmos, bem como as limitações impostas, específicas ou horizontais.

Em sentido contrário, nos acordos que seguem o padrão de lista negativa do NAFTA, todos os setores de serviços são liberalizados, salvo se explicitamente excluídos ou limitados nos devidos anexos ao acordo principal. Assim, em geral, a estipulação de reservas aos serviços e investimentos está estruturada em 
dois anexos: o anexo I, para as reservas em relação às medidas não-conformes; e o anexo II, para reservas em relação aos setores, subsetores ou atividades que possam manter medidas já existentes ou adotar novas ou mais restritivas medidas nãoconformes. Ambos usualmente se referem a reservas em relação às obrigações impostas pelas disciplinas relativas ao tratamento nacional e nação mais favorecida (serviços e investimentos), ao acesso a mercados (serviços), à presença local (serviços), aos requisitos de desempenho (investimentos) e à diretoria executiva e conselho de administração (investimentos).

Como linha comum a praticamente todos os acordos analisados, o movimento de pessoas físicas (modo 4) não é liberalizado ou sequer coberto pelo capítulo de comércio de serviços, salvo sob condições bastantes específicas indicadas como compromissos horizontais ou no âmbito das limitações de acesso a mercados e tratamento nacional. Em geral, existe um capítulo exclusivo para tratar disso, no qual as exceções em geral se referem a visitantes em missão de negócios e empregados transferidos dentro de companhias que possuam representação nos países com os quais se tem acordos preferenciais de comércio. Particularmente, quanto aos compromissos em relação a serviços educacionais, é comum que expressamente indiquem que os compromissos específicos de acesso a mercados e tratamento nacional em qualquer modo de serviços não sejam lidos de forma a permitir o reconhecimento de títulos universitários para fins de admissão, registro e qualificação para a prática profissional de estrangeiros em seus territórios.

Da mesma forma, tanto acordos de lista positiva quanto acordos de lista negativa excluem da esfera de abrangência dos mesmos os serviços prestados no exercício da autoridade governamental, em especial através da inclusão de uma disposição nesse sentido no capítulo de serviços. É comum que se some a isso a exclusão do ensino público ou a manutenção de amplas reservas para a educação pública e/ou serviços sociais, limitando os compromissos em educação superior aos prestadores privados de serviços. 


\subsection{Análise dos acordos selecionados}

A escolha dos países específicos e da União Europeia, dos seus acordos preferenciais de comércio selecionados, e das categorias e formas como serão analisados obedece aos critérios recém referidos. A sequência na qual os acordos país/bloco a país/bloco são trabalhados, por sua vez, segue uma ordem que combina sobretudo a maior disposição apresentada na liberalização do comércio de serviços educacionais e a opção por modelos de acordos que se assemelham primeiro ao NAFTA e depois ao GATS: Estados Unidos, Austrália, Chile, Cingapura, Índia, China e União Europeia. Assim, em um extremo é colocado os Estados Unidos, com um padrão uniforme em torno da lista negativa e do tratamento de investimentos em comércio de serviços pelo capítulo de investimentos; seguido de Austrália, Chile e Cingapura, com padrões que eventualmente variam segundo os diferentes parceiros comerciais; e, por fim, Índia, China e União Europeia, com um padrão muito próximo ao do GATS, ainda que com inovações, em especial nos seus últimos acordos.

\subsubsection{Acordos preferenciais de comércio dos Estados Unidos}


Tabela 05 - Acordos Preferenciais de Comércio dos Estados Unidos

\begin{tabular}{|c|c|c|c|c|c|}
\hline $\begin{array}{l}\text { Parceiro } \\
\text { comercial }\end{array}$ & Acordo & 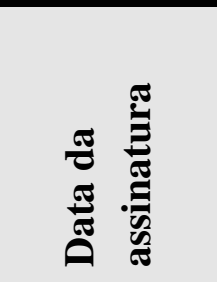 & 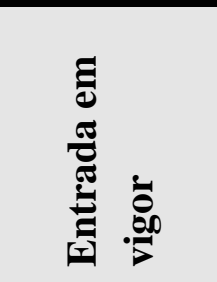 & 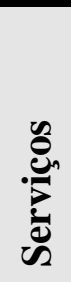 & 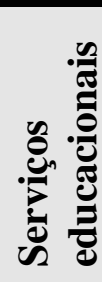 \\
\hline Cingapura & $\begin{array}{l}\text { United States-Singapore Free Trade Agreement } \\
\text { (USSFTA) }\end{array}$ & 06.05 .2003 & 01.01 .2004 & $\mathrm{X}$ & $\mathrm{X}$ \\
\hline Chile & $\begin{array}{l}\text { Free Trade Agreement between the Government of the } \\
\text { United States of America and the Government of the } \\
\text { Republic of Chile }\end{array}$ & 06.06 .2003 & 01.12 .2004 & $\mathrm{X}$ & $\mathrm{X}$ \\
\hline Austrália & $\begin{array}{l}\text { United States-Australia Free Trade Agreement } \\
\text { (AUSFTA) }\end{array}$ & 18.05.2004 & 01.01 .2005 & $\mathrm{X}$ & $\mathrm{X}$ \\
\hline Marrocos & United States-Morocco Free Trade Agreement & 15.06.2004 & 01.01 .2006 & & \\
\hline Peru & Peru - United States Trade Promotion Agreement & 18.04.2006 & 01.02 .2009 & $X$ & $X$ \\
\hline Colômbia & Colombia - United States Trade Promotion Agreement & 22.11.2006 & 15.05.2012 & $\mathrm{X}$ & $\mathrm{X}$ \\
\hline
\end{tabular}




\begin{tabular}{|c|c|c|c|c|c|c|c|c|c|}
\hline & 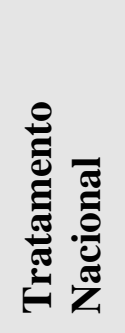 & 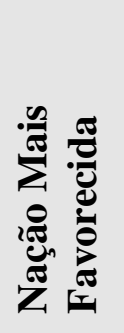 & 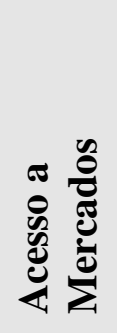 & 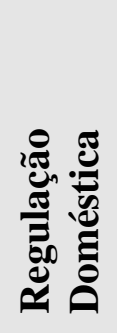 & 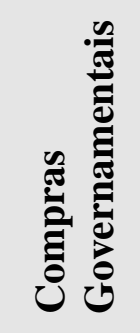 & :气 & 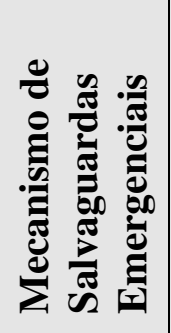 & $\begin{array}{l}\frac{\pi}{\pi} \\
\frac{\pi}{3} \\
\frac{0}{0} \\
0 \\
\frac{0}{0} \\
\frac{0}{2}\end{array}$ & 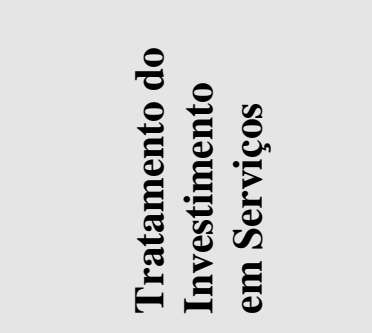 \\
\hline $\begin{array}{l}\text { Estados Unidos - } \\
\text { Cingapura }\end{array}$ & $\mathrm{X}$ & $\mathrm{X}$ & $\mathrm{X}$ & $\mathrm{X}$ & $\begin{array}{l}\text { capítulo } \\
\text { próprio }\end{array}$ & & & negativa & capítulo de investimentos \\
\hline $\begin{array}{l}\text { Estados Unidos - } \\
\text { Chile }\end{array}$ & $\mathrm{X}$ & $\mathrm{X}$ & $\mathrm{X}$ & $\mathrm{X}$ & $\begin{array}{l}\text { capítulo } \\
\text { próprio }\end{array}$ & & & negativa & capítulo de investimentos \\
\hline $\begin{array}{l}\text { Estados Unidos - } \\
\text { Austrália }\end{array}$ & $\mathrm{X}$ & $\mathrm{X}$ & $\mathrm{X}$ & $\mathrm{X}$ & $\begin{array}{l}\text { capítulo } \\
\text { próprio }\end{array}$ & & & negativa & capítulo de investimentos \\
\hline $\begin{array}{l}\text { Estados Unidos - } \\
\text { Marrocos }\end{array}$ & \multicolumn{9}{|c|}{ sem disposições sobre comércio de serviços } \\
\hline $\begin{array}{l}\text { Estados Unidos - } \\
\text { Peru }\end{array}$ & $X$ & $\mathrm{X}$ & $\mathrm{X}$ & $\mathrm{X}$ & $\begin{array}{l}\text { capítulo } \\
\text { próprio }\end{array}$ & & & negativa & capítulo de investimentos \\
\hline $\begin{array}{l}\text { Estados Unidos - } \\
\text { Colômbia }\end{array}$ & $\mathrm{X}$ & $\mathrm{X}$ & $\mathrm{X}$ & $\mathrm{X}$ & $\begin{array}{l}\text { capítulo } \\
\text { próprio }\end{array}$ & & & negativa & capítulo de investimentos \\
\hline
\end{tabular}

Elaboração pelo autor a partir de tabela proposta por Matoo e Sauvé (2011, p. 244-246 e 255-256). 
A abordagem dos Estados Unidos aos acordos preferenciais de comércio é uma versão evoluída do NAFTA, com o modelo de lista negativa e a disciplina dos investimentos em serviços pelo capítulo de investimentos, e os modos 1,2 e 3 regulamentados pelo capítulo de comércio transfronteiriço de serviços. O escopo dos acordos estadunidenses, assim, tende a ser estruturalmente padronizado e o conteúdo das suas disposições bastante uniforme, com o objetivo principal de obter acesso a mercados. ${ }^{462}$

No âmbito de suas obrigações, o capítulo que abrange o comércio transfronteiriço de serviços envolve as seguintes disciplinas: tratamento nacional, tratamento de nação mais favorecida, acesso a mercados, presença local, regulação doméstica, transparência, reconhecimento, transferências e pagamentos e denegação de benefícios. O capítulo de investimentos, por sua vez, traz: tratamento nacional, tratamento de nação mais favorecida, padrão mínimo de tratamento, expropriação, transferências, requisitos de desempenho, diretoria executiva e conselho de administração, denegação de benefícios, sistema de solução de controvérsias investidor-Estado. Excepcionalmente, o Acordo com a Austrália, que segue exatamente a mesma estrutura dos demais, apresenta uma abordagem diferente em relação ao sistema de solução de controvérsias investidor-Estado, prevendo um sistema de consultas, com a possibilidade de acessar o sistema de solução de controvérsias geral do acordo. ${ }^{463}$

Os acordos contam com um artigo - no acordo com Cingapura, o Artigo 8.2:2; no acordo com o Chile, o Artigo 11.1:3, por exemplo - com o qual se convenciona que, ainda que regulamentados no âmbito do capítulo de investimentos, às medidas das Partes que afetem o comércio de serviços via investimentos (modo 3 )

\footnotetext{
${ }^{462}$ AHEARN, Raymond J. Europe's Preferential Trade Agreements: Status, Content, and Implications. Congressional Research Service, Mar. 2010, p. 13.

463 "Article 11.16: Consultations on Investor-State Dispute Settlement

1. If a Party considers that there has been a change in circumstances affecting the settlement of disputes on matters within the scope of this Chapter and that, in light of such change, the Parties should consider allowing an investor of a Party to submit to arbitration with the other Party a claim regarding a matter within the scope of this Chapter, the Party may request consultations with the other Party on the subject, including the development of procedures that may be appropriate. On such a request, the Parties shall promptly enter into consultations with a view towards allowing such a claim and establishing such procedures.

2. For greater certainty, nothing in this Article prevents a Party from raising any matter arising under this Chapter pursuant to the procedures set out in Chapter 21 (Institutional Arrangements and Dispute Settlement). Nor does anything in this Article prevent an investor of a Party from submitting to arbitration a claim against the other Party to the extent permitted under that Party's law".
} 
se apliquem também as regras de acesso a mercados, regulação doméstica e transparência do capítulo sobre o comércio transfronteiriço de serviços.

Em particular, o modelo definido para o tratamento nacional segue o modelo NAFTA, ${ }^{464}$ com as possíveis implicações dessa redação já descritas anteriormente. Quanto à regulação doméstica, os dispositivos não cobrem todos os pontos abarcados pelo Artigo VI do GATS. São trazidas disciplinas que correspondem parcialmente às disposições do Artigo VI:3 e 4 do GATS. De um lado, quando for exigida autorização para a prestação de um serviço, fica o dever das autoridades competentes da Parte, dentro de um período de tempo razoável após a submissão de uma inscrição, informar o pretendente da decisão concernente à inscrição. A pedido do pretendente, devem também as autoridades competentes providenciar informações relativas ao andamento da inscrição (application). ${ }^{465}$ Além disso, para assegurar que medidas relativas a requisitos e procedimentos em matéria de qualificação, de normas técnicas e requisitos em matéria de licenças não constituam obstáculos desnecessários ao comércio de serviços, cada Parte deverá se esforçar para garantir que tais medidas: a) sejam baseados em critérios objetivos e transparentes, tais como a competência e a habilidade para prestar o serviço; b) não sejam mais gravosas que o necessário para assegurar a qualidade do serviço; c) no caso dos procedimentos em matéria de licença, não constituam em si mesmos uma restrição para a prestação do serviço. ${ }^{466}$

Em acesso aos mercados, é repetida a fórmula do Artigo XVI do GATS, porém com a exclusão da alínea "f", que trata especificamente das limitações sobre a participação do capital estrangeiro expressas como limite percentual máximo de detenção de ações por estrangeiros ou relativas ao valor total, individual ou agregado, de investimentos estrangeiros. Como já referido, existem leituras no sentido de que a omissão da alínea "f" não traria maiores consequências, na medida em que a imposição de limites ao capital estrangeiro seria vedada pelo próprio dispositivo do tratamento nacional.

A estipulação de reservas aos serviços e investimentos está estruturada em torno do anexo I, para reservas em relação às medidas não-conformes, e do anexo

\footnotetext{
464 "Each Party shall accord to service suppliers of the other Party treatment no less favorable than that it accords, in like circumstances, to its own service suppliers" (Article 8.3:1, United States-Singapore Free Trade Agreement, 2003).

${ }^{465}$ Article 8.8:1, United States-Singapore Free Trade Agreement, 2003.

${ }^{466}$ Article 8.8:2(a), (b) e (c), United States-Singapore Free Trade Agreement, 2003.
} 
II, para reservas quanto aos setores, subsetores ou atividades que possam manter medidas já existentes ou adotar novas ou mais restritivas medidas não-conformes. Da mesma forma do que acontece com as disciplinas gerais, os Estados Unidos mantêm o mesmo padrão também nas suas reservas. No início de cada acordo os serviços prestados no exercício da autoridade governamental são explicitamente excluídos da cobertura do capítulo sobre o comércio transfronteiriço de serviços. No anexo 1 não são feitas reservas gerais relevantes ao setor educacional e tampouco reservas específicas. Já no anexo 2 são apresentadas reservas a serviços sociais, quando os Estados Unidos se reservam ao direito de adotar ou manter qualquer medida com respeito à prestação de educação pública, na medida em que seja estabelecida ou mantida para um fim público.

\begin{abstract}
Sector: Social Services
Obligations Concerned: National Treatment, Most-FavouredNation Treatment, Local Presence, Performance Requirements and Senior Management and Board of Directors

Description: (Investment and Cross Border Trade in Services) The United States reserves the right to adopt or maintain any measure with respect to the provision of law enforcement and correctional services, and the following services to the extent they are social services established or maintained for a public purpose: income security or insurance, social security or insurance, social welfare, public education, public training, health, and child care.
\end{abstract}

No acordo com os Estados Unidos, o Peru, por sua vez, no Anexo 1, faz uma reserva em relação à aplicação das obrigações de tratamento nacional em investimentos em todos os setores, relacionada à compra de terras a 50 quilômetros da fronteira peruana. No Anexo 2, o Peru adota duas reservas. A primeira, abrangendo todos os setores, garante ao Peru o direito de adotar ou manter qualquer medida que conceda tratamento diferenciado a países sob qualquer acordo bilateral ou multilateral em vigor ou assinado antes da entrada em vigor do acordo com os Estados Unidos.

Sectors: All Sectors

Obligations Concerned: Most-Favored-Nation Treatment (Article 10.4 or Article 11.3)

Description: (Cross Border Trade in Services and Investment) Peru reserves the right to adopt or maintain any measure that accords differential treatment to countries under any bilateral or multilateral international agreement in force or signed prior to the date of entry into force of this Agreement. 
Peru reserves the right to adopt or maintain any measure that accords differential treatment to countries under any bilateral or multilateral international agreement in force or signed after the date of entry into force of this Agreement involving:

(a) aviation;

(b) fisheries; or

(c) maritime matters, including salvage.

Por fim, o Peru, tal como os Estados Unidos, também insere uma reserva em relação a todos os serviços sociais, garantindo aí o direito de adotar ou manter qualquer medida relativa à educação pública.

\section{Sector: Social Services}

Obligations Concerned: National Treatment, Most-FavouredNation Treatment, Local Presence, Performance Requirements and Senior Management and Board of Directors

Description: (Investment and Cross Border Trade in Services) Peru reserves the right to adopt or maintain any measure with respect to the provision of law enforcement and correctional services, and the following services to the extent that they are social services established or maintained for a public purpose: income security and insurance, social security, social welfare, public education, public training, health, and childcare.

A Colômbia, por sua vez, no Anexo 1, não adota nenhuma reserva geral com impactos sobre o setor educacional, e tampouco reservas específicas. Já no Anexo 2, repete a reserva relacionada a serviços sociais, incluindo educação pública, e insere uma reserva às regras de acesso a mercados em certos setores, entre eles o educacional. Com tal limitação, a Colômbia garante o direito de adotar ou manter qualquer medida quanto a serviços educacionais primários, secundários e de ensino superior, com respeito aos requisitos referentes ao tipo específico de entidade legal que poderá prestar tais serviços.

\footnotetext{
Sector: Certain Sectors

Obligations Concerned: Market Access

Description: (Cross Border Trade in Services) - Colombia reserves the right to adopt or maintain any measure in the following sectors:

(e) primary and secondary education services, and, with respect to higher education, requirements relating to the specific type of legal entity that may supply such services.
}

\subsubsection{Acordos preferenciais de comércio da Austrália}




\begin{tabular}{|c|c|c|c|c|c|}
\hline $\begin{array}{l}\text { Parceiro } \\
\text { comercial }\end{array}$ & Acordo & 苞 & 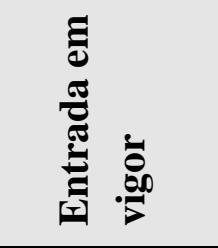 & 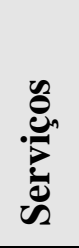 & \\
\hline Cingapura & Singapore-Australia Free Trade Agreement (SAFTA) & 17.02.2003 & 28.07.2003 & $X$ & $\mathrm{X}$ \\
\hline $\begin{array}{l}\text { Estados } \\
\text { Unidos }\end{array}$ & $\begin{array}{l}\text { United States-Australia } \text { Free } \\
\text { (AUSFTA) }\end{array}$ & 18.05.2004 & 01.01 .2005 & $\mathrm{X}$ & $\mathrm{X}$ \\
\hline Tailândia & Thailand-Australia Free Trade Agreement (TAFTA) & 05.07 .2004 & 01.01 .2005 & $X$ & $\mathrm{X}$ \\
\hline Chile & Australia-Chile Free Trade Agreement & 30.07.2008 & 06.03.2009 & $\mathrm{X}$ & $\mathrm{X}$ \\
\hline Malásia & Malaysia-Australia Free Trade Agreement (MAFTA) & 22.05.2012 & 01.01 .2013 & $X$ & $X$ \\
\hline
\end{tabular}




\begin{tabular}{|c|c|c|c|c|c|c|c|c|c|}
\hline & 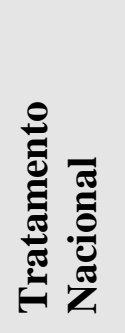 & 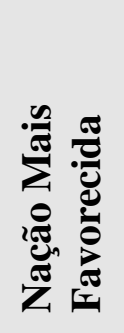 & 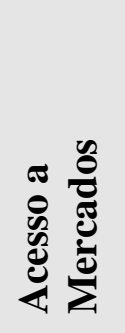 & 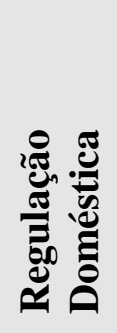 & 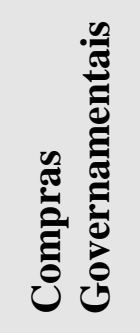 & $\frac{\mathscr{0}}{\stackrel{0}{0}}$ & 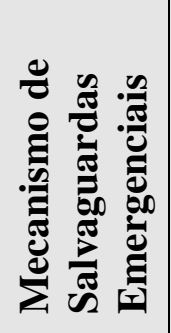 & $\begin{array}{l}\frac{\pi}{0} \\
\frac{0}{3} \\
\frac{0}{0} \\
\frac{0}{0} \\
\frac{0}{8} \\
\sum\end{array}$ & 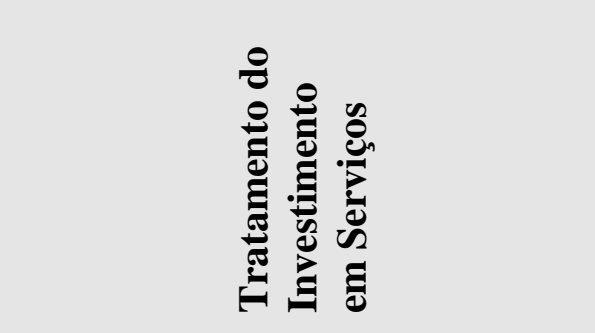 \\
\hline Austrália - Cingapura & $\mathrm{X}$ & & $\mathrm{X}$ & $\mathrm{X}$ & $\begin{array}{l}\text { capítulo } \\
\text { próprio }\end{array}$ & consultas & & negativa & capítulo de serviços (presença comercial) \\
\hline $\begin{array}{l}\text { Austrália - } \\
\text { Estados Unidos }\end{array}$ & $\mathrm{X}$ & $\mathrm{X}$ & $\mathrm{X}$ & $\mathrm{X}$ & $\begin{array}{l}\text { capítulo } \\
\text { próprio }\end{array}$ & & & negativa & capítulo de investimentos \\
\hline Austrália - Tailândia & $\mathrm{X}$ & & $\mathrm{X}$ & $\mathrm{X}$ & & & & positiva & capítulo de serviços (presença comercial) \\
\hline Austrália - Chile & $\mathrm{X}$ & $\mathrm{X}$ & $\mathrm{X}$ & $\mathrm{X}$ & $\begin{array}{l}\text { capítulo } \\
\text { próprio }\end{array}$ & & & negativa & capítulo de investimentos \\
\hline Austrália - Malásia & $\mathrm{X}$ & & $\mathrm{X}$ & $\mathrm{X}$ & & & consultas & positiva & capítulo de serviços (presença comercial) \\
\hline
\end{tabular}


A Austrália tem com os Estados Unidos e com o Chile acordos que repetem o padrão NAFTA, com lista negativa, investimentos em serviços regulamentado pelo capítulo de investimentos, e redação dos dispositivos de tratamento nacional e acesso a mercados nos mesmos moldes. De forma geral, as disciplinas tanto do capítulo de serviços quanto do capítulo sobre investimentos são as mesmas presentes nos acordos estadunidenses. Ao mesmo tempo, contam com um dispositivo que garante aos investimentos em serviços a aplicação das disposições do capítulo sobre o comércio transfronteiriço de serviços referentes ao acesso a mercados, regulação doméstica e transparência, no caso dos Estados Unidos, e ao acesso a mercados e presença local, no caso do Chile.

De outro lado, os acordos com Cingapura, Tailândia e Malásia são relativamente mais simples em comparação com os outros dois, de modo que o tratamento de investimentos em serviços como modo 3, e a redação das disciplinas de tratamento nacional e acesso a mercados se aproximam do modelo do GATS, sem a previsão do tratamento de nação mais favorecida. No entanto, enquanto com Tailândia e Malásia a abordagem escolhida para a liberalização é a da lista positiva, o acordo com Cingapura adota a lista negativa, mesmo mantendo investimentos em serviços regulamentados pelo próprio capítulo de serviços.

Todos os acordos repetem a exceção do GATS aos serviços prestados no exercício da autoridade governamental dentro do território de qualquer uma das partes, e incluem compromissos em educação superior - nos acordos com lista positiva - ou não excluem o setor da cobertura preferencial - nos acordos com lista negativa. Com Estados Unidos e Chile, quanto às reservas, a Austrália inclui as mesmas reservas em relação à educação pública e ao ensino primário:

Sector: Social Services

Obligations concerned: National Treatment (Articles 10.2 and 11.3); Most-Favoured-Nation Treatment (Articles 10.3 and 11.4); Local Presence (Article 10.5); Performance Requirements (Article 11.9); Senior Management and Boards of Directors (Article 11.10); Market Access (Article 10.4).

Descriptions: (Cross-Border Trade in Services and Investment) Australia reserves the right to adopt or maintain any measure with respect to the provision of law enforcement and correctional services, and the following services to the extent that they are social services established or maintained for a public purpose: income security or insurance, social security or insurance, social 


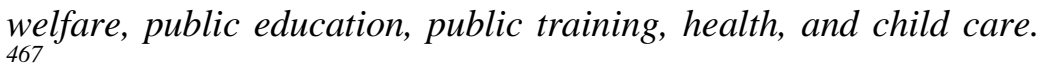

No acordo com Cingapura ${ }^{468}$, cujas reservas referem-se somente ao capítulo sobre o comércio de serviços, é colocada a mesma reserva em relação à educação pública. Também no anexo II, a Austrália incluiu reservas para o desenvolvimento do setor privado de serviços prestados no exercício da autoridade governamental e para a privatização de entidades ou bens de propriedade do governo, ambas em relação a acesso a mercados e tratamento nacional em todos os setores. Ainda, de maneira bastante ampla, a Austrália reservou para si, em relação a tratamento nacional especificamente no setor educacional, o direito de adotar ou manter qualquer medida com respeito à prestação de serviços educacionais por meio de presença comercial.

\begin{abstract}
Sector: All
Type of Reservation: Market Access and National Treatment Description of Reservation: Australia reserves the right to adopt or maintain any measure with respect to: a) the devolvement to the private sector of services provided in the exercise of governmental authority at the time that the Agreement comes into force; and b) the privatisation of government owned entities or assets.
\end{abstract}

\title{
Sector: Educational Services
}

Subsector: Education services other than primary education services - Industry classification: 922, 923, 924, 929

Type of Reservation: National Treatment

Description of Reservation: Australia reserves the right to adopt or maintain any measure with respect to the supply of educational services through commercial presence. ${ }^{469}$

Nesses três acordos, a Austrália mantém um núcleo comum de reservas gerais, abrangendo todos os setores. No anexo I, são mantidas medidas quanto a investimentos que exigem notificação e aprovação prévia pelo governo australiano de compras de ativos superiores a um determinado patamar, bem como do

\footnotetext{
${ }^{467}$ Australia-Chile Free Trade Agreement.

${ }^{468}$ O capítulo 15 do Acordo Austrália-Cingapura trata especificamente sobre cooperação em matéria educacional. O objetivo central está na promoção de vínculos entre os indivíduos e o entendimento mútuo entre os países nos seguintes pontos: processos de garantia da qualidade, educação à distância em todos os níveis, sistemas de educação primária e secundária, educação superior, ensino técnico e treinamento vocacional, colaboração da indústria para o treinamento técnico e vocacional, e o treinamento de professores e desenvolvimento.

${ }^{469}$ Singapore-Australia Free Trade Agreement (SAFTA).
} 
estabelecimento por estrangeiros de novos negócios na Austrália que envolvam investimentos superiores a 10 milhões de dólares australianos. Da mesma forma, mantém-se o direito de impor limites à compra de imóveis por estrangeiros e requisitos de residência, que determinam que ao menos um diretor - dois, no caso do acordo com Cingapura - e um secretário de qualquer companhia estrangeira deva ser residente na Austrália. Já no anexo II, são estabelecidas reservas para adoção ou manutenção pela Austrália de medidas que concedam tratamento preferencial para indivíduos ou organizações nativas (indigenous) na aquisição, estabelecimento ou operação de qualquer empreendimento comercial ou industrial no setor de serviços em relação a tratamento nacional, requisitos de desempenho, presença local e diretoria executiva e conselho de administração -; e medidas sobre o investimento de estrangeiros em terras urbanas em território australiano, que não diga respeito ao desenvolvimento de propriedades comerciais não-residenciais.

Nos acordos com Malásia e Tailândia, com as listas positivas, a maior parte dessas reservas são traduzidas em limitações inseridas nos cronogramas de liberalização no âmbito dos compromissos horizontais, abrangendo todos os setores de serviços liberalizados mediante compromissos específicos. Assim, na coluna referente às limitações ao acesso a mercados, uma série de atividades de investimentos devem ser notificadas ao governo australiano e podem ser proibidas, sujeitas a providências cautelares, ou permitidas sujeitas a condições ou da forma como propostas. Como limitações ao tratamento nacional, repete-se a exigência de que ao menos dois diretores de companhias públicas devem residir na Austrália, e excepciona-se as medidas existentes e futuras, em qualquer nível governamental, que concedam direitos ou tratamento preferencial a qualquer indivíduo ou organização nativa (indigenous).

Em ambos os acordos, os compromissos específicos apresentados pela Austrália em relação aos serviços de educação superior são os mesmos: compromissos de liberalização sem limitações de acesso a mercados para os modos 1 , 2 e 3, e sem limitações de tratamento nacional para os modos 1 e 2. Para esses, as únicas limitações que se impõem são as colocadas pelos compromissos horizontais. No entanto, não há qualquer compromisso de tratamento nacional em relação ao modo 3, ou seja, no caso de investimentos malaios ou tailandeses em serviços (presença comercial), o governo australiano permanece livre para manter ou adotar 
qualquer medida discriminatória comparativamente ao tratamento concedido aos seus nacionais.

A Malásia estabelece limitações horizontais que dizem respeito sobretudo à aquisição de propriedades e à concessão de incentivos a corporações estatais engajadas em setores de serviços promovidos pelo governo malásio. Nos compromissos específicos, em educação superior nos modos 1, 2 e 3, a única limitação estabelecida está relacionada ao modo 3, em acesso a mercados, onde somente são permitidos investimentos estrangeiros a partir de empreendimentos conjuntos (joint ventures), sem que o capital estrangeiro exceda 70\%. Já a Tailândia, sem nenhum compromisso específico em serviços educacionais, estabelece por meio dos compromissos horizontais a obrigatoriedade de que a participação estrangeira em instituições privadas seja inferior a $50 \%$ e o número de acionistas estrangeiros represente menos do que $50 \%$ do número total de acionistas. Ainda, o gerente de uma instituição privada deve ser um nacional tailandês.

\subsubsection{Acordos preferenciais de comércio do Chile}




\begin{tabular}{|c|c|c|c|c|c|}
\hline $\begin{array}{l}\text { Parceiro } \\
\text { comercial }\end{array}$ & Acordo & 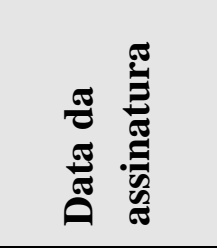 & 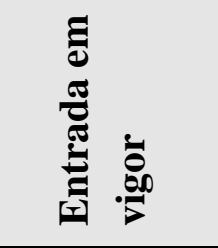 & : & \\
\hline $\begin{array}{l}\text { União } \\
\text { Europeia }\end{array}$ & $\begin{array}{l}\text { Agreement establishing an association between the } \\
\text { European Community and its Member States, of the one } \\
\text { part, and the Republic of Chile, of the other part }\end{array}$ & 18.11.2002 & 01.10 .2003 & $\mathrm{X}$ & UE \\
\hline $\begin{array}{l}\text { Coreia } \\
\text { do Sul }\end{array}$ & $\begin{array}{l}\text { Free Trade Agreement between the Government of the } \\
\text { Republic of Korea and the Government of the Republic } \\
\text { of Chile }\end{array}$ & 15.02.2003 & 01.04 .2004 & $\mathrm{X}$ & $\mathrm{X}$ \\
\hline $\begin{array}{l}\text { Estados } \\
\text { Unidos }\end{array}$ & $\begin{array}{l}\text { Free Trade Agreement between the Government of the } \\
\text { United States of America and the Government of the } \\
\text { Republic of Chile }\end{array}$ & 06.06 .2003 & 01.01 .2004 & $\mathrm{X}$ & $\mathrm{X}$ \\
\hline EFTA & $\begin{array}{l}\text { Free Trade Agreement Between the EFTA States and } \\
\text { The Republic of Chile }\end{array}$ & 26.06.2003 & 01.12 .2004 & $\mathrm{X}$ & \\
\hline China & $\begin{array}{l}\text { Free Trade Agreement Between The Government of the } \\
\text { People's Republic of China and The Government of The } \\
\text { Republic of Chile }\end{array}$ & 18.11.2005 & 01.10 .2006 & $\mathrm{X}$ & China \\
\hline Índia & Preferential Trade Agreement between India and Chile & 08.03 .2006 & 11.09.2007 & & \\
\hline
\end{tabular}




\begin{tabular}{|c|l|c|c|c|c|}
\hline Panamá & Tratado de Libre Comercio Panamá-Chile & 27.06 .2006 & 07.03 .2008 & $\mathrm{X}$ & $\mathrm{X}$ \\
\hline Peru & $\begin{array}{l}\text { Acuerdo de Libre Comercio entre el Gobierno de la } \\
\text { República del Perú y el Gobierno de la República de } \\
\text { Chile }\end{array}$ & 22.08 .2006 & 01.03 .2009 & $\mathrm{X}$ & $\mathrm{X}$ \\
\hline Colômbia & Acuerdo de Libre Comercio entre Chile y Colombia & 27.11 .2006 & 08.05 .2009 & $\mathrm{X}$ & $\mathrm{X}$ \\
\hline Japão & $\begin{array}{l}\text { Agreement Between Japan and Chile for a Strategic } \\
\text { Economic Partnership }\end{array}$ & 27.03 .2007 & 03.09 .2007 & $\mathrm{X}$ & $\mathrm{X}$ \\
\hline Austrália & $\begin{array}{l}\text { Australia-Chile Free Trade Agreement } \\
\text { Turquia }\end{array}$ & $\begin{array}{l}\text { Free Trade Agreement Between The Republic of Chile } \\
\text { and The Republic of Turkey }\end{array}$ & 14.07 .2009 & 01.03 .2011 & $\mathrm{X}$ \\
\hline Malásia & \begin{tabular}{l} 
Malaysia-Chile Free Trade Agreement \\
\hline
\end{tabular}
\end{tabular}




\begin{tabular}{|c|c|c|c|c|c|c|c|c|c|}
\hline Chile - Coreia do Sul & $\mathrm{X}$ & & & & $\begin{array}{l}\text { capítulo } \\
\text { próprio }\end{array}$ & & & negativa & capítulo de investimentos \\
\hline Chile - Estados Unidos & $\mathrm{X}$ & $X$ & $\mathrm{X}$ & $\mathrm{X}$ & $\begin{array}{l}\text { capítulo } \\
\text { próprio }\end{array}$ & & & negativa & capítulo de investimentos \\
\hline Chile - EFTA & $\mathrm{X}$ & $X$ & $\mathrm{X}$ & $\mathrm{X}$ & $\begin{array}{l}\text { capítulo } \\
\text { próprio }\end{array}$ & & & positiva & capítulo de serviços (presença comercial) \\
\hline
\end{tabular}

\footnotetext{
${ }^{470}$ The Supplementary Agreement on Trade in Services of the FTA Between Chile and China.
} 


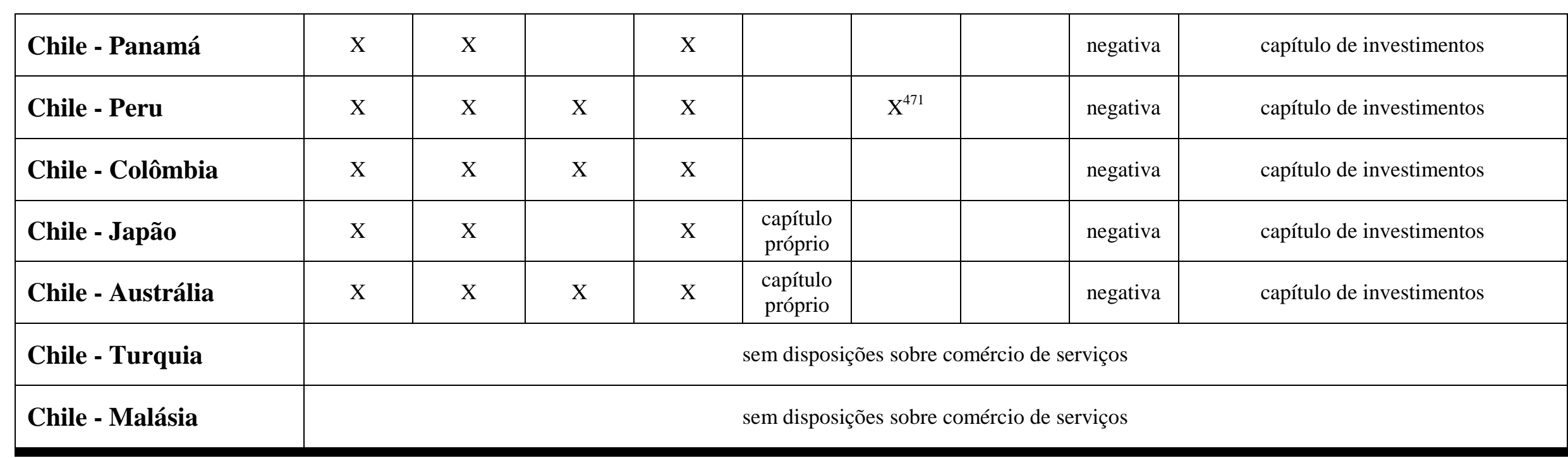

\footnotetext{
${ }^{471}$ Articulo 12.2: Subsidios
}

1. Las Partes intercambiarán información sobre todos los subsidios o donaciones que distorsionen el comercio transfronterizo de servicios, tales como los préstamos, garantías y seguros apoyados por el gobierno. El primer intercambio se realizará en un plazo de 1 año a partir de la entrada en vigor del presente Acuerdo.

2. Si los resultados de las negociaciones relacionadas con el Artículo XV.1 del AGCS (o los resultados de cualquier negociación similar, desarrollada en otro foro multilateral en el cual ambas Partes participen) entran en vigor para las Partes, este artículo deberá ser modificado, previa consulta entre ellas, para que dichos resultados sean incorporados al presente Acuerdo. Las Partes coordinarán tales negociaciones, según corresponda. 
Dos 13 acordos selecionados do Chile, três não trazem disposições sobre o comércio de serviços - com Índia, Malásia e Turquia. Nos demais, é notável a preferência do Chile pelo modelo mais próximo ao NAFTA, com a lista negativa e o tratamento dos investimentos em serviços pelo capítulo específico sobre investimentos. As exceções a essa abordagem possivelmente se deram por opção dos parceiros comerciais: a China, que sempre opta pela lista positiva em seus acordos, e a Associação Europeia de Livre Comércio (EFTA) e a União Europeia que, como blocos econômicos, adotam a lista positiva para contemplar os interesses específicos de seus membros. No entanto, nesses acordos com lista positiva, em nenhum o Chile ofereceu compromissos de liberalização no setor educacional.

Assim, os acordos com Coreia do Sul, Estados Unidos, Panamá, Peru, Colômbia, Japão e Austrália se valem da lista negativa para a liberalização do comércio de serviços e tratam do investimento em serviços (modo 3) no capítulo específico de investimentos. Os acordos com Estados Unidos, Peru e Colômbia contam com um dispositivo que torna aplicável aos investimentos em serviços as disciplinas sobre acesso a mercados, transparência e regulação doméstica do capítulo sobre comércio transfronteriço de serviços. Por sua vez, o acordo com a Austrália inclui um dispositivo semelhante que, porém, se estende somente às disciplinas sobre acesso a mercados e presença local.

Com exceção dos acordos com Panamá e Japão - sem disciplinas sobre acesso a mercados -, e com a Coreia do Sul - sem disciplinas sobre o tratamento de nação mais favorecida, acesso a mercados e regulação doméstica ${ }^{472}$-, os demais acordos de lista negativa tendem a repetir o modelo de acordo norte-americano, inspirado no NAFTA, incluindo a redação dos artigos referentes ao tratamento nacional, tratamento de nação mais favorecida, acesso a mercados ${ }^{473}$ e regulação

\footnotetext{
${ }^{472}$ Assim, as reservas são feitas somente em relação ao Tratamento Nacional e Presença Local. A consequência é que Modo 1, 2 e 4 de serviços, em comparação com os outros Acordos, são regulados de maneira mais superficial. Contudo, Modo 3 (presença comercial), que aqui se confunde com investimento, é regulado pelo capítulo de investimentos e, portanto, possui uma regulação ampla.

${ }^{473}$ No Acordo Chile-Peru, o artigo "Acesso aos Mercados" aparece sob o nome "Restricciones cuantitativas no discriminatórias" (Artículo 12.5), enquanto no Acordo Chile-Colômbia o mesmo texto Acordo Chile-Peru aparece sob o Artigo 'Acesso aos Mercados'. Em ambos é repetida a fórmula do Artigo XVI do GATS, porém com a exclusão da alínea ' $\mathrm{f}$ ', que trata especificamente das limitações sobre a participação do capital estrangeiro expressas como limite percentual máximo de detenção de ações por estrangeiros ou relativas ao valor total, individual ou agregado, de investimentos estrangeiros. Quanto à regulação doméstica, o artigo não cobre todos os pontos abarcados pelo Artigo VI do GATS. São trazidas disciplinas que correspondem parcialmente às disposições do Artigo VI:3 e 4 do GATS.
} 
doméstica ${ }^{474}$. Em geral, com algumas alterações, os capítulos de investimentos tendem a trazer disposições sobre tratamento nacional, tratamento de nação mais favorecida, padrão mínimo de tratamento, perdas e compensação, requisitos de desempenho, diretoria executiva e conselho de administração, reservas e exceções, transferência, expropriação e compensação, denegação de benefícios e solução de controvérsias investidor-Estado. ${ }^{475}$

Os acordos chilenos repetem no corpo do tex to o dispositivo do GATS que excepciona os serviços prestados no exercício da autoridade governamental. Já no anexo II, o Chile repete nesses acordos as mesmas duas reservas que tocam diretamente sobre o setor educacional. A primeira reserva em relação ao tratamento nacional, tratamento de nação mais favorecida, presença local e diretoria executiva e conselho de administração - investimentos e serviços - permite manter medidas existentes ou adotar novas ou mais restritivas sobre serviços sociais, os quais incluem a educação pública: ${ }^{476}$

Sector: Social Services

Industry Classification: CPC 913 Compulsory Social Security Services; CPC 92 Education Services; CPC 93 Health and Social Services

Type of Reservation: National Treatment (Articles 10.3, 11.3); Local Presence (Article 11.4); Performance Requirements (Article 10.7); Senior Management and Boards of Directors (Article10.8);

Description: (Cross-Border Trade in Services and Investment) Chile reserves the right to adopt or maintain any measure with respect to the provision of public law enforcement and correctional services, and the following services to the extent that they are social services established or maintained for a public purpose: income security or insurance, social security or insurance, social welfare, public education, public training, health care, and child care. ${ }^{477}$

\footnotetext{
${ }^{474}$ No acordo com o Japão não se tem um artigo sob o nome "Regulação Doméstica", tampouco uma regulação mais completa nessa área, como presente na maioria dos acordos chilenos. Todavia, o acordo apresenta no Artigo 112, "Autorização, qualificação, padrões técnicos e licenciamento", medidas relacionadas à adoção ou manutenção de medidas de modo a não constituir barreiras desnecessárias ao comércio transfronteiriço de serviços, o que corresponde a um parte das disposições usualmente presentes nos artigos sobre 'Regulação Doméstica' dos acordos do Chile.

${ }^{475} \mathrm{O}$ acordo com o Panamá remete a regulação dos investimentos para um acordo específico assinado antes com o Chile - Convenio entre la República de Chile y la República de Panamá para la Promoción y Protección Recíproca de las Inversiones -, de 8 de novembro de 1996.

${ }^{476}$ Excepcionalmente, no acordo com a Coreia do Sul, ambas reservas não são feitas em relação ao tratamento de nação mais favorecida, dada a ausência desta disciplina no capítulo sobre comércio transfronteiriço de serviços.

${ }^{477}$ Free Trade Agreement between the Government of the Republic of Korea and the Government of the Republic of Chile.
} 
A segunda reserva, no mesmo anexo, se dá em relação ao tratamento nacional, tratamento de nação mais favorecida, presença local - serviços -, garantindo qualquer medida com respeito a pessoas físicas que prestam serviços educacionais:

\begin{abstract}
Sector: Education
Industry Classification: CPC 92 Education Services Type of Reservation: National Treatment (Article 11.3); Local Presence (Article 11.4)

Description: (Cross-Border Trade in Services) Chile reserves the right to adopt or maintain any measure relating to natural persons who render educational services, including teachers and ancillary personnel rendering educational services in elementary education, kindergarten, preschool, special education, primary and high school education, higher education, professional, technical, and university education, including educational establishments of any kind as well as sponsors of educational establishments, schools, lyceums, academies, training centres, professional and technical institutes, and/or universities. This reservation does not apply to the provision of services related to second language training, corporate, business and industrial training, and skill upgrading which includes consulting services, relating to technical support and advice and curriculum and program development in education. ${ }^{478}$
\end{abstract}

Como reservas gerais, que incidem sobre todos os investimentos e/ou serviços, no anexo I, o Chile inclui reservas em relação ao tratamento nacional investimentos - quanto à propriedade de imóveis em área de fronteira, e reservas em relação ao tratamento nacional e presença local - serviços - para medidas que garantem que um mínimo de $85 \%$ dos empregados que trabalham para o mesmo empregador sejam pessoas físicas chilenas. No anexo II, é incluída reserva em relação ao tratamento nacional e nação mais favorecida - investimentos - para qualquer medida quanto a requisitos de residência para a propriedade de terras costeiras por investidores estrangeiros, bem como qualquer medida que denegue a investidores estrangeiros qualquer direito ou preferência outorgados a populações autóctones.

Colômbia e Japão incluem uma reserva muito semelhante em relação aos serviços sociais, enquanto o Peru estabelece as duas mesmas reservas chilenas. A Coreia do Sul, por sua vez, além de garantir a manutenção ou adoção de medidas não

\footnotetext{
${ }^{478}$ Free Trade Agreement between the Government of the Republic of Korea and the Government of the Republic of Chile.
} 
conformes em relação a pessoas físicas prestadoras de serviços educacionais, também faz o mesmo em relação ao estabelecimento de uma série de instituições de ensino. $\mathrm{O}$ número de universidades a serem estabelecidas por estrangeiros está limitado a uma instituição por cada cidade metropolitana ou província, não sendo permitida, ainda, o estabelecimento de uma universidade em Seul.

Sector: Education Services

Industry Classification: CPC 92 Education Services

Type of Reservation: National Treatment (Articles10.3, 11.3); Performance Requirement (Article 10.7); Local Presence (Article 11.4)

Description: (Cross-Border Trade in Services and Investment) Korea reserves the right to adopt or maintain any measure related to natural persons who render education services, including teachers and ancillary personnel rendering educational services in preschool education, primary education, secondary education, higher education, technical and vocational education, and other education and training.

Korea reserves the right to adopt or maintain any measure related to the establishment of kindergartens, primary schools, secondary schools, teacher's universities, and other higher education institutions (excluding 4-year institution) by foreign nationals. In addition, the number of universities, which will be established by foreign nationals, is limited to one institution to each metropolitan city or province. However, establishing a university in Seoul or in the vicinities is not permitted. ${ }^{479}$

\subsubsection{Acordos preferenciais de comércio de Cingapura}

\footnotetext{
${ }^{479}$ Free Trade Agreement between the Government of the Republic of Korea and the Government of the Republic of Chile.
} 
Tabela 11 - Acordos Preferenciais de Comércio de Cingapura

\begin{tabular}{|c|c|c|c|c|c|}
\hline $\begin{array}{l}\text { Parceiro } \\
\text { comercial }\end{array}$ & Acordo & 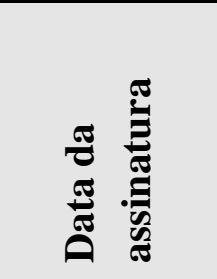 & 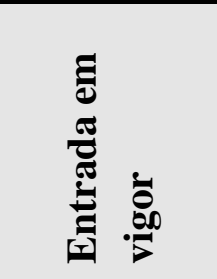 & 总 & 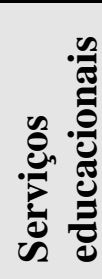 \\
\hline $\begin{array}{c}\text { Nova } \\
\text { Zelândia }\end{array}$ & $\begin{array}{l}\text { New Zealand-Singapore Closer Economic Partnership } \\
\text { (ANZSCEP) }\end{array}$ & 14.11.2000 & 01.01 .2001 & $\mathrm{X}$ & $\mathrm{X}$ \\
\hline Japão & $\begin{array}{l}\text { Japan-Singapore Economic Agreement for a New-Age } \\
\text { Partnership (JSEPA) }\end{array}$ & 13.01.2002 & 30.11 .2002 & $\mathrm{X}$ & $\mathrm{X}$ \\
\hline EFTA & $\begin{array}{l}\text { European Free Trade Association-Singapore Free Trade } \\
\text { Agreement (ESFTA) }\end{array}$ & 26.06 .2002 & 01.01 .2003 & $\mathrm{X}$ & EFTA \\
\hline Austrália & Singapore-Australia Free Trade Agreement (SAFTA) & 17.02.2003 & 28.07.2003 & $\mathrm{X}$ & $\mathrm{X}$ \\
\hline $\begin{array}{l}\text { Estados } \\
\text { Unidos }\end{array}$ & $\begin{array}{l}\text { United States-Singapore Free Trade Agreement } \\
\text { (USSFTA) }\end{array}$ & 06.05 .2003 & 01.01 .2004 & $\mathrm{X}$ & $\mathrm{X}$ \\
\hline $\begin{array}{l}\text { Coreia } \\
\text { do Sul }\end{array}$ & Korea-Singapore Free Trade Agreement (KSFTA) & 04.01 .2004 & 02.03 .2006 & $\mathrm{X}$ & $\mathrm{X}$ \\
\hline
\end{tabular}




\begin{tabular}{|c|l|c|c|c|c|}
\hline Índia & $\begin{array}{l}\text { India-Singapore Comprehensive Economic Cooperation } \\
\text { Agreement (CECA) }\end{array}$ & 29.06 .2005 & 01.08 .2005 & $\mathrm{X}$ & $\begin{array}{c}\text { Cinga } \\
\text { pura }\end{array}$ \\
\hline China & China-Singapore Free Trade Agreement (CSFTA) & 23.10 .2008 & 01.01 .2009 & $\mathrm{X}$ & $\mathrm{X}$ \\
\hline Peru & Singapore-Peru Free Trade Agreement & 01.08 .2009 & 28.05 .2008 & $\mathrm{X}$ & $\mathrm{X}$ \\
\hline $\begin{array}{c}\text { Costa } \\
\text { Rica }\end{array}$ & Singapore-Costa Rica Free Trade Agreement & 06.04 .2010 & 01.07 .2013 & $\mathrm{X}$ & $\mathrm{X}$ \\
\hline
\end{tabular}




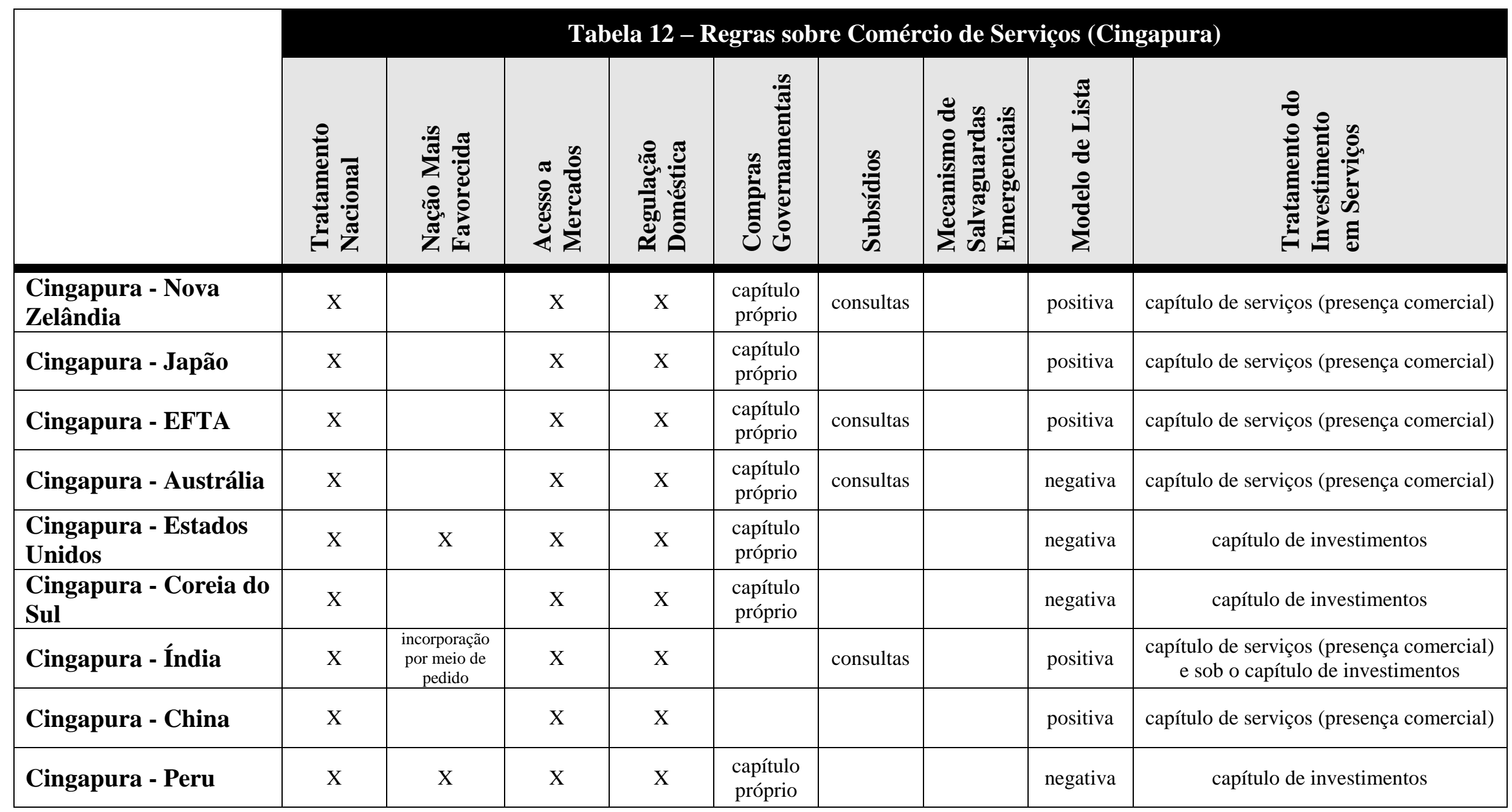




\begin{tabular}{|c|c|c|c|c|c|c|c|}
\hline $\begin{array}{l}\text { Cingapura - Costa } \\
\text { Rica }\end{array}$ & $\mathrm{X}$ & $\mathrm{X}$ & $\mathrm{X}$ & $\mathrm{X}$ & $\begin{array}{l}\text { capítulo } \\
\text { próprio }\end{array}$ & negativa & capítulo de investimente \\
\hline
\end{tabular}


Cingapura tem, entre os seus acordos selecionados, metade organizados em torno da abordagem da lista positiva, com Nova Zelândia, Japão, EFTA, Índia e China. Os três primeiros foram assinados entre os anos 2000 e 2002, seguidos por uma série de acordos com lista negativa interrompida somente pelos acordos com Índia e China, que invariavelmente adotam a lista positiva em seus instrumentos. Assim, os outros cinco acordos, assinados entre 2003 e 2010, seguiram um modelo inspirado no NAFTA, com disciplinas próximas as dos acordos estadunidenses, de lista negativa e tratamento dos investimentos em serviços pelo capítulo específico de investimentos, e um dispositivo que ainda torna aplicável algumas disciplinas do capítulo sobre comércio transfronteiriço de serviços ao modo 3 de serviços - no acordo com Estados Unidos e Peru os artigos sobre acesso a mercados, regulação doméstica e transparência; no acordo com Coreia do Sul o artigo sobre regulação doméstica; e no acordo com Costa Rica os artigos sobre acesso a mercados e regulação doméstica. No entanto, no acordo com a Austrália, ainda que organizado em torno da lista negativa, o modo 3 de serviços permanece regulado pelo capítulo de serviços, combinando elementos característicos tanto do GATS quando do NAFTA.

Assim, os acordos com Coreia do Sul, Estados Unidos, Peru e Costa Rica mantêm uma grande similitude entre seus capítulos de comércio transfronteiriço de serviços e sobre investimentos. No primeiro, o acordo com a Coreia do Sul não conta com o tratamento de nação mais favorecida - ausente também no capítulo sobre investimentos - e com disciplinas sobre transparência - ausente também no acordo com a Costa Rica -, enquanto o dispositivo sobre regulação doméstica segue a redação do GATS - os acordos com Estados Unidos, Peru e Costa Rica adotam uma redação que corresponde somente a uma parte do dispositivo do GATS. De resto, esses quatro acordos compartilham boa parte das outras disciplinas, com o dispositivo de acesso a mercados igual ao do GATS, porém sem a alínea f, regras sobre presença local, reconhecimento, e transferências e pagamentos. Sobre investimentos, se dá o mesmo, com disposições sobre tratamento nacional, tratamento de nação mais favorecida - salvo no acordo com a Coreia da Sul -, padrão mínimo de tratamento, expropriação, transferências, requisitos de desempenho, diretoria executiva e conselho de administração, e sistema de solução de controvérsias investidor-Estado. 
Nos acordos com Estados Unidos, Coreia do Sul, Peru e Costa Rica, no anexo I, referente às medidas existentes, são incluídas por Cingapura reservas gerais, passíveis de afetar também investimentos em educação, em relação às obrigações de tratamento nacional a serviços transfronteiriços e investimentos estrangeiros, de um lado, e de tratamento nacional e tratamento de nação mais favorecida somente a investimentos, de outro. A primeira diz respeito à exigência de que, para o registro de um negócio por um estrangeiro, deva ser apontado um gerente local, cidadão ou residente permanente de Cingapura, ou com o passe de emprego do país. Do mesmo modo, todas as empresas constituídas localmente devem possuir ao menos um diretor da companhia e dois agentes das subsidiárias de companhias estrangeiras residentes em Cingapura. A segunda refere-se à possibilidade de Cingapura alienar terras do Estado de maneira inconsistente com as obrigações de tratamento nacional e/ou tratamento de nação mais favorecida. Especificamente em matéria educacional, quanto ao tratamento nacional a investimentos estrangeiros, Cingapura permite somente a instituições locais de ensino superior operar programas de graduação e pósgraduação em medicina.

Já no anexo II, no âmbito das reservas para medidas futuras, Cingapura resguarda o seu direito de manter ou adotar qualquer medida que afete o desenvolvimento do setor privado de serviços prestados no exercício da autoridade governamental, bem como a prestação de serviços educacionais primário e secundário para cidadãos de Cingapura. Ambas reservas se referem às obrigações de acesso a mercado, tratamento nacional, tratamento de nação mais favorecida, presença local, requisitos de desempenho, e diretoria executiva e conselho de administração em relação a serviços transfronteiriços e investimentos estrangeiros. Ao mesmo tempo, são reservadas medidas que afetam a definição do tipo de atividade passível de conduzida em determinado território, incluindo políticas de zoneamento e planejamento urbano. Nos acordos com o Peru e com a Costa Rica, reserva-se também o direito de manter ou adotar qualquer medida que afete a prestação de serviços sociais.

No acordo com Cingapura, o Peru repete, agora em ambos os anexos, as mesmas reservas já feitas em seus acordos com Estados Unidos e Chile, sobre serviços sociais e sobre pessoas físicas que prestam serviços educacionais. Já a Coreia do Sul, em relação ao anexo I, mantém reservas para que estrangeiros com intenção 
de fazer um investimento direto estrangeiro devam antes comunicar o Ministério do Comércio, Indústria e Energia, e reservas para obrigatoriedade de que empresas com um determinado número de funcionários contratem um certo percentual de pessoas com necessidades especiais. A tendência de reservas bastantes específicas por parte da Coreia de Sul se aprofunda em relação aos serviços educacionais. A reserva sulcoreana para serviços transfronteiriços e investimentos estrangeiros, em relação a tratamento nacional, acesso a mercados, presença local, e diretoria executiva e conselho de administração, mantém medidas que garantem que 50\% ou mais dos membros do conselho de administração de escolas privadas sejam compostos por cidadãos coreanos; limites sobre os créditos obtidos em uma universidade que podem ser reconhecidos em outra; que somente aquelas pessoas jurídicas sem fins lucrativos aprovadas pelos Ministério da Educação possam estabelecer instituições de ensino superior; que somente certas instituições de ensino superior possam se estabelecer na região metropolitana de Seul, com foco nas universidades de tecnologia; que o número total de estudantes para cada instituição de ensino superior possa ser restringido pelo Ministro da Educação, e que universidades possam operar empreendimentos conjuntos com universidades estrangeiras já acreditadas no país, nos campos da tecnologia, de ciências básicas, de estudos internacionais e de especialização das respectivas universidades coreanas.

No anexo II, para medidas futuras, a Coreia do Sul inclui reservas para a manutenção ou adoção de qualquer medida com respeito à aquisição de terras por estrangeiros, assim como qualquer medida que afete o desenvolvimento do setor privado de serviços prestados no exercício da autoridade governamental. Por fim, também especificamente no setor educacional, a Coreia do Sul insere uma ampla reserva sobre as obrigações de tratamento nacional e acesso a mercados em relação aos serviços transfronteiriços ou investimentos estrangeiros, de forma que reserva a si o direito de manter ou adotar qualquer medida relativa a praticamente cada um dos quatro modos de serviços, incluindo o estabelecimento por estrangeiros de uma série de instituições de ensino primário, secundário e superior:

Sector: Education Services

Industry Classification: Primary Education Services (CPC 921), Secondary Education Services (CPC 922), Higher Education 
Services (CPC 923), Adult Education Services (CPC 924), Other Education Services (CPC 929)

Type of Reservation: National Treatment, Market Access

Description: (Cross-Border Trade in Services and Investment)

Korea reserves the right to adopt or maintain any measure related to the provision of a service from the territory of a Party into the territory of the other Party for primary education, secondary education, higher education, health and medical-related adult education, degree-conferring adult education, adult education via broadcasting, vocational training services provided by institutions under authority delegated or financially supported by the government and other education services.

Korea reserves the right to adopt and maintain any measure related to the provision of a service in the territory of a Party by $a$ person of that Party to a person of the other Party for primary and secondary school students.

Korea reserves the right to adopt or maintain any measure related to the establishment of primary and secondary education institutions, teachers' universities, school of education, universities via broadcasting and communications, cyber universities, all health and medical related higher education institutions, health and medical related adult education institutions, adult education institutions conferring or leading to degrees, adult education institutions via broadcasting, life-long education facilities via information and technology, vocational training institutions with authority delegated or financially supported by government and other education institutions (excluding language education) by foreign nationals.

Korea reserves the right to adopt or maintain any measure related to natural persons who render education services including teachers and ancillary personnel providing educational services in primary education, secondary education, vocational and technical education, higher education, adult education and other education and training services. ${ }^{480}$

Os acordos de Cingapura com Nova Zelândia, Japão, Índia e China seguem o modelo regulatório do GATS, com a mesma estrutura de disciplinas, a lista positiva de liberalização e o tratamento de investimentos em serviços pelo modo 3 no próprio capítulo de serviços. Desses, o único que apresenta algumas particularidades é o acordo com a Índia, que apresenta mais similitudes com os demais acordos indianos do que com os acordos anteriores de Cingapura. Nele é previsto um dispositivo que atua como cláusula de integração entre os capítulos de serviços e de investimentos, uma possibilidade de consultas sobre o tema subsídios, e a incorporação do tratamento de nação mais favorecida somente por meio de pedido específico.

${ }^{480}$ Korea-Singapore Free Trade Agreement (KSFTA). 
No cronograma de liberalização junto ao acordo com a Nova Zelândia, no âmbito dos compromissos horizontais, Cingapura não consolida qualquer compromisso em modo 4, salvo permissão temporária para o movimento de gerentes, executivos e especialistas transferidos dentro de empresas que prestam serviços em Cingapura, e de visitantes em missão de negócios. Em relação ao modo 3, entre outros pontos, na coluna de limitações ao tratamento nacional, condiciona a presença comercial, o direito de estabelecimento e o movimento de pessoas jurídicas às mesmas limitações replicadas depois como reservas nos acordos de Cingapura de lista negativa, que dizem respeito à exigência de apontar um gerente local para o registro de um negócio por um estrangeiro, e de empresas constituídas localmente possuírem ao menos um diretor da companhia e dois agentes das subsidiárias de companhias estrangeiras residentes em Cingapura. $\mathrm{Na}$ esfera dos compromissos específicos, assim como a Nova Zelândia, o país consolida os modos 1, 2 e 3, sem qualquer limitação em acesso a mercados e tratamento nacional, com a ressalva, porém, de que não se aplicam ao reconhecimento de títulos universitários para fins de admissão, registro e qualificação para prática profissional em Cingapura.

As mesmas limitações horizontais do acordo com a Nova Zelândia são repetidas nos cronogramas de liberalização dos acordos posteriores com Japão, Índia e China. O movimento de pessoas físicas (modo 4) permanece excluído da abrangência dos acordos, porém as exceções presentes no cronograma do acordo com a Nova Zelândia, em vez de descritas na lista, são especificadas em capítulo ou anexo próprio. Nos acordos com o Japão e a Índia somam-se ainda limitações sobre o tratamento nacional em relação aos quatro modos de serviços quanto a subsídios ou subvenções, especificadas somente no acordo com o Japão como destinadas a ajudar a desenvolver empreendedores locais, a auxiliar pessoas jurídicas a expandirem suas operações, e ligadas a outras considerações de políticas nacionais (national policy), incluindo bem-estar social, desenvolvimento de recursos humanos, promoção cultural, moradia, educação e saúde. No que tange aos compromissos específicos em educação superior, nos acordos com Japão, Índia e China, é mantida a consolidação de compromissos plenos nos modos 1, 2 e 3 de serviços, com a ressalva na coluna das limitações sobre o acesso a mercados de que Cingapura mantém o direito de limitar o número de pessoas que podem buscar a graduação em medicina de acordo com a oferta total de pessoas. 
O Japão, por sua vez, como limitação horizontal sobre as obrigações de tratamento nacional, reserva-se ao direito de manter no modo 3 subsídios para pesquisa e desenvolvimento. Em relação aos serviços de educação superior, os modos 1 e 2 são consolidados sem limitações de acesso a mercados e tratamento nacional. Já no modo 3, em acesso a mercados, se coloca a obrigação de que universidades devam ser estabelecidas por pessoas jurídicas sem fins lucrativos, voltadas ao fim de prestar serviços educacionais sob a lei japonesa; em tratamento nacional, não limitações específicas, somente a referida limitação horizontal, que atinge todos os setores liberalizados.

\subsubsection{Acordos preferenciais de comércio da Índia}




\begin{tabular}{|c|c|c|c|c|c|}
\hline $\begin{array}{l}\text { Parceiro } \\
\text { comercial }\end{array}$ & Acordo & 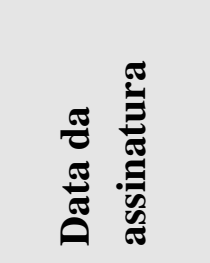 & 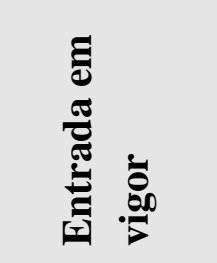 & : & 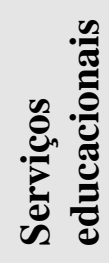 \\
\hline Cingapura & $\begin{array}{l}\text { India-Singapore Comprehensive Economic } \\
\text { Cooperation Agreement (CECA) }\end{array}$ & 29.06.2005 & 01.08 .2005 & $\mathrm{X}$ & $\begin{array}{l}\text { Cinga } \\
\text { pura }\end{array}$ \\
\hline Chile & Preferential Trade Agreement between India and Chile & 08.03.2006 & 11.09.2007 & & \\
\hline $\begin{array}{l}\text { Coreia do } \\
\text { Sul }\end{array}$ & $\begin{array}{l}\text { India-Korea Comprehensive Economic Partnership } \\
\text { Agreement }\end{array}$ & 07.08.2009 & 01.01 .2010 & $\mathrm{X}$ & $\mathrm{X}$ \\
\hline Japão & $\begin{array}{l}\text { Comprehensive Economic Partnership Agreement } \\
\text { Between the Republic of India and Japan }\end{array}$ & 15.02 .2011 & 01.08 .2011 & $\mathrm{X}$ & $\mathrm{X}$ \\
\hline Malásia & $\begin{array}{l}\text { Comprehensive Economic Cooperation Agreement } \\
\text { between the government of India and the government } \\
\text { of Malaysia }\end{array}$ & 18.02 .2011 & 18.07.2011 & $\mathrm{X}$ & $X$ \\
\hline
\end{tabular}




\begin{tabular}{|c|c|c|c|c|c|c|c|c|c|}
\hline Índia - Chile & \multicolumn{9}{|c|}{ sem disposições sobre comércio de serviços } \\
\hline Índia - Coreia do Sul & $\mathrm{X}$ & $\begin{array}{l}\text { incorporacãao } \\
\text { por meio de } \\
\text { pedido }\end{array}$ & $\mathrm{X}$ & $X$ & & consultas & & & $\begin{array}{l}\text { capítulo de serviços (presença comercial) } \\
\text { e sob o capítulo de investimentos }\end{array}$ \\
\hline Índia - Japão & $\mathrm{X}$ & $\begin{array}{c}\text { incorporacacão } \\
\text { por meio de } \\
\text { pedido }\end{array}$ & $\mathrm{X}$ & $\mathrm{X}$ & & consultas & & positiva & capítulo de serviços (presença comercial) \\
\hline
\end{tabular}


Dos cinco acordos selecionados da Índia, somente o acordo com o Chile não conta com disposições sobre o comércio de serviços. Os demais acordos, com Cingapura, Coreia do Sul, Japão e Malásia, são pautados pelo modelo regulatório do GATS, com a mesma estrutura de disciplinas, a lista positiva de liberalização e o tratamento de investimentos em serviços pelo modo 3 no próprio capítulo de serviços - de maneira exclusiva somente nos dois últimos acordos, e integrado com o capítulo de investimentos nos dois primeiros acordos. O Acordo Índia-Cingapura apresenta uma forma diferente de relação entre as disciplinas sobre comércio de serviços e investimentos, com uma cláusula de integração entre ambas as matérias, repetida posteriormente no Acordo Índia-Coreia do Sul. O capítulo de serviços abrange os quatro modos de fornecimento de serviços. Todavia, o Artigo $7.24^{481}$ atua como uma cláusula de interação com as disciplinas de investimentos ao determinar que uma série de disposições sobre investimentos sejam aplicadas, mutatis mutandis, aos serviços prestados mediante presença comercial. Estabelece-se, assim, um desenho complementar entre os dois capítulos, ${ }^{482}$ aplicando-se regras sobre compensação por perdas, expropriação, repatriação, sub-rogação, medidas de interesse público, formalidades especiais e requisitos de informação, acesso a cortes de justiça, diretoria executiva e conselho de administração, outras obrigações e proibição de requisitos de desempenho.

Além disso, os quatro acordos preveem a possibilidade de consultas sobre o tema subsídios. Ainda que não gerem obrigações específicas e tampouco estejam sujeitos ao mecanismo de solução de controvérsias, tais dispositivos estabelecem um mecanismo de consultas em caso de uma das partes sentir-se prejudicada por subsídios concedidos pela parte contrária. Com exceção do acordo com a Malásia, sem disposições sobre o tratamento de nação mais favorecida, os outros três tratam da incorporação do tratamento de nação mais favorecida somente por meio de pedido específico.

\footnotetext{
${ }^{481}$ Article 7.24 (Services-Investment Linkage)

1. "For the avoidance of doubt, the Parties confirm, in respect of Chapter 6, that:

(a) the following articles of Chapter 6 apply, mutatis mutandis, to measures affecting the supply of service by a service supplier of a Party through commercial presence in the territory of the other Party, only to the extent that they relate to an investment, regardless of whether or not such service sector is scheduled in a Party's Schedule of Specific Commitments in Annex 7A or 7B".

${ }^{482}$ ORGANIZAÇÃO PARA COOPERAÇÃO E DESENVOLVIMENTO ECONÔMICO. Investment for Development: Investment Policy Co-operation with Non-OECD Economies. Annual Report 2006. Paris: OECD Publications, 2006, p. 108.
} 
Os acordos com Coreia do Sul, Japão e Malásia apresentam compromissos em serviços educacionais tanto por parte da Índia quanto pelos seus parceiros comerciais. Neles, as limitações horizontais indianas são praticamente as mesmas. Como limitações horizontais sobre o acesso a mercados no modo 3 (presença comercial), é estabelecido que, para os setores e subsetores inseridos no cronograma de liberalização, deve-se aplicar a política sobre investimento direto estrangeiro, anunciada de tempo em tempo pelo governo da Índia. Nos acordos com Coreia do Sul e Japão, essa redação mais ampla é especificada em torno de setores nos quais investimentos estrangeiros necessitam de aprovação prévia do órgão indiano responsável pela promoção de investimentos estrangeiros, e dos tipos de pessoas jurídicas através das quais as companhias estrangeiras podem estabelecer operações na Índia. Quanto às limitações sobre tratamento nacional, também em relação ao modo 3: i) no caso de colaboração com empresas do setor público ou participação do governo como parceiro em empreendimentos conjuntos, será dada preferência de acesso aos prestadores estrangeiros ou entidades que ofereçam os melhores termos para transferência de tecnologia; ii) deverão se aplicar as leis tributárias específicas; iii) subsídios, quando concedidos, estarão disponíveis somente para prestadores domésticos de serviços. No que toca ao movimento de pessoas físicas (modo 4), não são consolidados compromissos, salvo as exceções estabelecidas em capítulo próprio nos acordos. No cronograma do acordo com a Malásia, em todos os setores e subsetores comprometidos, salvo especificação em contrário, a Índia permite o acesso de visitantes em missão de negócios e empregados transferidos dentro de empresas também estabelecidas em território indiano.

No campo dos compromissos específicos indianos em serviços de educação superior, ainda que praticamente idênticos nos três acordos, a Índia restringe a liberalização do modo 3 nos acordos com Japão e Malásia, justamente seus últimos acordos já em vigor. Enquanto no acordo Índia-Coreia do Sul, modo 2 (consumo no exterior) de serviços em acesso a mercados, e modos 1, 2 e 3 em tratamento nacional são consolidados sem limitações, nos outros dois acordos o modo 3 de serviços deixa de ser consolidado em relação às obrigações de tratamento nacional. Assim, permanece livre o governo indiano para adotar qualquer medida discriminatória em relação a investidores japoneses e malaios na esfera do modo 3. De resto, nos três acordos, os compromissos de acesso a mercados no modo 1 estão sujeitos à condição 
de que os prestadores de serviços estejam sujeitos às regulações aplicáveis aos prestadores domésticos nos seus países de origem; e, no modo 3, sujeitos à condição de que as taxas a serem cobradas dos estudantes possam ser fixadas pela autoridade apropriada e que tais taxas não conduzam à cobrança de valores para a admissão, além e acima das taxas regulares (captation fees) ${ }^{483}$, e ao lucro desmedido (profiteering) ${ }^{484}$. Particularmente, no Acordo Índia-Malásia, se soma a essas condições para o acesso a mercados um teto de $51 \%$ para a participação do capital estrangeiro em investimentos em educação.

\section{EDUCATIONAL SERVICES \\ C. Higher Education Services (CPC 923) \\ Limitations on Market Access}

3) Subject to a foreign equity ceiling of 51 per cent and the condition that fees to be charged can be fixed by an appropriate authority and that such fees do not lead to charging capitation fees or to profiteering. Subject further to such regulations, already in place or to be prescribed by the appropriate regulatory authority.

\footnotetext{
${ }^{483}$ A expressão "captation fees", em um contexto educacional indiano, se refere à prática de coletar pagamentos para admitir estudantes em instituições educacionais, valores que vão além das taxas regulares e, em geral, não são de conhecimento prévio dos estudantes ingressantes. Trata-se de uma prática que tem contribuído para a comercialização em larga escala da educação, sem a manutenção dos padrões educacionais. Na redação da lei do estado indiano de Maharashtra, o conceito de 'capitation fee' é estabelecido da seguinte forma: "any amount, by whatever name called, whether in case or kind paid or collected directly or indirectly, in excess of the prescribed or, as the case may be approved rates of fees regulated under section 4" (Maharashtra Educational Institutions (Prohibition of Capitation Fee) Act, 1987. Disponível em: www.frcrce.ac.in/Notices/cf.pdf). No âmbito nacional, uma série de projetos de lei visam coibir tal prática, o mais duro deles tornando-a um delito e recomendando pena máxima de reclusão de três anos, mais multa, pela cobrança de "captation fees" e pela propaganda enganosa ou informação errada intencionalmente inserida no prospecto do curso (ROY, Shreya; GHOSH, Deboljyoti. Pvt colleges defend capitation fee. The Financial Express, 22 Mar. 2010. Disponível em: http://www.financialexpress.com/news/pvt-colleges-defend-capitationfee/593749/0).

${ }^{484}$ Ainda que o conceito de "profiteering" tenda a significar um lucro desproporcionalmente grande ou manifestamente abusivo, e que algumas decisões da Suprema Corte da Índia diferenciem a ideia de excedente razoável da de "profiteering" - "reasonable surplus to meet the cost of expansion and augmentation of facilities, does not however, amount to profiteering" (KAPUR, Devesh; MEHTA, Pratap Bhanu. Indian Higher Education Reform: From Half-Baked Socialism to Half-Baked Capitalism. Center for International Development at Harvard University Working Paper n. 108, Set. 2004 , p. 21) -, representantes do governo indiano, em mais de uma situação, relacionam o sentido do termo 'profiteering' ao simples lucro, afirmando que a educação continuaria como um setor sem fins lucrativos e que o governo nunca permitiria o lucro na educação que iria como dividendos para acionistas (Profiteering in education by private sector will not be allowed: Sibal. The Hindu, 10 February 2010. Disponível em: http://www.thehindu.com/news/national/profiteering-in-education-byprivate-sector-will-not-be-allowed-sibal/article104274.ece), ou que a educação deveria ser deixada longe dos negócios e que não deve haver nenhum lucro com a mesma (Education shouldn't be a profit earning business: Chidambaram. The Indian Express, 17 Jan. 2010. Disponível em: http://archive.indianexpress.com/news/education-shouldnt-be-a-profit-earning-businesschidambaram/568290/). Assim, se lida de acordo com esse último significado, a limitação sobre o acesso a mercados no modo 3 inserida pela Índia pode significar a restrição às instituições privadas de ensino superior com fins lucrativos, tal como Coreia do Sul e Japão
} 
In the case of foreign investors having prior collaboration in that specific service sector in India, FIPB approval would be required. ${ }^{485}$

De outro lado, como limitações horizontais em relação ao acesso a mercados no modo 3, a Coreia do Sul incluiu possíveis restrições sobre a aquisição por estrangeiros de ações de companhias domésticas em certos setores, porém nenhum desses relacionados à educação; e a Malásia a necessidade de aprovação para determinadas aquisições de ativos de companhias malaias, fusões ou aquisições, incluindo propostas que resultem na propriedade ou no controle destas por interesses estrangeiros. Como limitações horizontais em relação a tratamento nacional no modo 3, a Coreia do Sul apresenta limitações sobre a aquisição de terras por investidores estrangeiros; o Japão a não consolidação de subsídios para pesquisa e desenvolvimento, que podem ser distribuídos pelo governo de maneira discriminatória em relação aos investidores estrangeiros; e, por fim, a Malásia traz limitações sobre a compra e alienação de terras e propriedades por estrangeiros e limitação de incentivos/preferências para determinadas corporações malaias envolvidas em setores de serviços promovidos pelo governo.

Cada um a seu modo, os três países consolidaram compromissos educacionais no âmbito de seus acordos com a Índia. Os compromissos da Coreia do Sul em educação superior não incluem o ensino de medicina e demais áreas da saúde, o ensino para futuros professores da educação pré-primária, primária e secundária, e o ensino do direito. Ainda, somente é concedida permissão à entrada para entidades organizadas como pessoas jurídicas sem fins lucrativos estabelecidas unicamente para fornecer serviços educacionais sob a lei local. Não há qualquer compromisso sulcoreano de acesso a mercados em relação aos modos 1 e 4 , e de tratamento nacional em relação aos modos 1, 3 e 4. Em ambos o modo 2 é incluído sem limitações. Quanto ao acesso a mercados no modo 3, são colocadas uma série de limitações, entre elas a restrição a instituições de educação à distância, a possível restrição à instalação de instituições na área metropolitana de Seul, a limitação da operação conjunta de instituições locais com instituições estrangeiras, e a possível restrição do número de estudantes para cada instituição educacional.

\footnotetext{
${ }^{485}$ Comprehensive Economic Cooperation Agreement between the government of India and the government of Malaysia.
} 
A Malásia começa por condicionar o acesso ao mercado para investimentos estrangeiros (modo 3) à entrada sob a forma de empreendimento conjunto (joint venture), com participação estrangeira não superior a $49 \%$, podendo alcançar até $51 \%$ em alguns casos, como em cursos que sejam considerados importantes para atingir os objetivos educacionais malaios, e que tenham potencial para gerar receitas de exportação. A liberalização do modo 1 se dá unicamente quando necessário à presença comercial (modo 3), enquanto o modo 2 é consolidado sem limitações. No âmbito das obrigações de tratamento nacional, nos modos 1, 2 e 3, não há a consolidação de compromissos, inclusive para concessão de financiamento ou subsídios federias ou estaduais.

\section{EDUCATIONAL SERVICES \\ C. Higher Education}

\section{Limitations on Market Access}

1) Unbound except for requirement of commercial presence

2) None

3) Only through a joint venture with foreign equity not exceeding 49 per cent. Up to $51 \%$ foreign equity will be considered which include among others: (a) courses deemed important to attain Malaysia's educational objectives; (b) potential to generate export revenues.

4) Unbound except for measures affecting the entry and temporary stay of natural persons defined below: Intra-corporate Transferees Lecturers and experts 10 lecturers and/or experts but not more than 30 per cent of lecturers employed in an educational institution who possess the necessary qualifications, knowledge, credentials or experience.

\section{Limitations on National Treatment}

1), 2), 3) Unbound including for grant of federal or state funding or subsidies such as but not limited to land grants, tax benefits, scholarships and loans limited to institutions with Government of Malaysia equity or citizens/permanent residents.

4) Unbound, except for the categories of natural persons referred to in the market access column. 486

Por sua vez, o Japão consolida compromissos plenos, sem limitações específicas, nos quatro modos de serviços em educação superior, desde que prestadas por pessoas jurídicas sem fins lucrativos estabelecidas para fornecer serviços educacionais sob a lei japonesa.

\footnotetext{
${ }^{486}$ Comprehensive Economic Cooperation Agreement between the government of India and the government of Malaysia.
} 


\begin{tabular}{|c|c|c|c|c|c|}
\hline $\begin{array}{l}\text { Parceiro } \\
\text { comercial }\end{array}$ & Acordo & 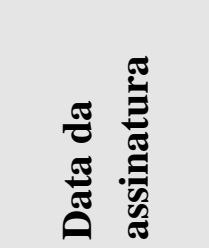 & 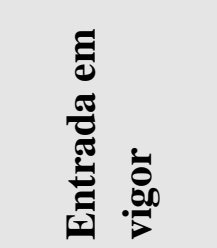 & 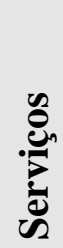 & 导 \\
\hline Chile & $\begin{array}{l}\text { Free Trade Agreement Between The Government of } \\
\text { the People's Republic of China and The Government of } \\
\text { the Republic of Chile }\end{array}$ & 18.11.2005 & 01.10 .2006 & $\mathrm{X}$ & China \\
\hline ASEAN & Agreement on Trade in Services ${ }^{487}$ & 01.2007 & 07.2007 & $\mathrm{X}$ & ASEAN \\
\hline $\begin{array}{c}\text { Nova } \\
\text { Zelândia }\end{array}$ & $\begin{array}{l}\text { Free Trade Agreement Between The Government of } \\
\text { the People's Republic of China And The Government } \\
\text { of New Zealand }\end{array}$ & 07.04 .2008 & 01.10 .2008 & $\mathrm{X}$ & $\mathrm{X}$ \\
\hline Cingapura & China-Singapore Free Trade Agreement (CSFTA) & 23.10 .2008 & 01.01 .2009 & $\mathrm{X}$ & $\mathrm{X}$ \\
\hline
\end{tabular}

\footnotetext{
${ }^{487}$ O primeiro acordo (Framework Agreement on China-ASEAN Comprehensive Economic Cooperation) foi assinado antes, em novembro de 2002. Na sequência vieram,
} respectivamente, os acordos sobre comércio de bens, comércio de serviços e investimentos. 


\begin{tabular}{|c|l|c|c|c|c|}
\hline Paquistão & $\begin{array}{l}\text { Agreement on Trade in Services between the } \\
\text { government of the People's Republic of China and the } \\
\text { government of the Islamic Republic of Pakistan } 488\end{array}$ & 21.02 .2009 & 10.10 .2009 & $\mathrm{X}$ & $\mathrm{X}$ \\
\hline Peru & China-Peru Free Trade Agreement & 28.04 .2009 & 01.03 .2010 & $\mathrm{X}$ & $\mathrm{X}$ \\
\hline $\begin{array}{c}\text { Costa } \\
\text { Rica }\end{array}$ & China-Costa Rica Free Trade Agreement & 08.04 .2010 & 01.08 .2011 & $\mathrm{X}$ & $\mathrm{X}$ \\
\hline
\end{tabular}

${ }^{488}$ Antes do acordo sobre comércio de serviços já tinha sido assinado o Acordo de Livre Comércio entre os dois países (Free Trade Agreement between the government of the People's Republic of China and the government of the Islamic Republic of Pakistan), em vigor desde julho de 2007. 


\begin{tabular}{|c|c|c|c|c|c|c|c|c|c|}
\hline China - ASEAN & $\mathrm{x}$ & & $\mathrm{x}$ & $\mathrm{X}$ & & $\mathrm{x}$ & consultas & positiva & capítulo de serviços (presença comercial) \\
\hline China - Nova Zelândia & $\mathrm{x}$ & $\mathrm{X}$ & $\mathrm{x}$ & $\mathrm{X}$ & & consultas & & positiva & capítulo de serviços (presença comercial) \\
\hline China - Cingapura & $\mathrm{x}$ & & $\mathrm{x}$ & $\mathrm{X}$ & & & & positiva & capítulo de serviços (presença comercial) \\
\hline China - Costa Rica & $\mathrm{X}$ & & $\mathrm{X}$ & $\mathrm{X}$ & & & & positiva & capítulo de serviços (presença comercial) \\
\hline
\end{tabular}


A China, independentemente do parceiro comercial, tende a repetir o mesmo padrão de acordo, pautado pelo modelo regulatório do GATS, com a mesma estrutura de disciplinas, a lista positiva de liberalização e o tratamento de investimentos em serviços pelo modo 3 no próprio capítulo de serviços. Mesmo os compromissos horizontais e os compromissos específicos no setor educacional são praticamente idênticos.

No âmbito dos compromissos horizontais dos cronogramas de liberalização dos seus acordos de comércio selecionados, nas limitações de acesso a mercados relativamente ao modo 3 , a China começa por definir os tipos jurídicos das empresas estrangeiras com investimentos no país, entre empresas de capital estrangeiro, de controle total estrangeiro, e empreendimentos conjuntos (joint venture). $\mathrm{O}$ estabelecimento de subsidiárias por empresas estrangeiras não foi oferecido como compromisso e continua vedado, salvo se indicado ao contrário em subsetores específicos. De outro lado, é permitida a instalação de escritórios de representação de empresas estrangeiras na China, mas elas não poderão se engajar em nenhuma atividade com fins lucrativos, exceção feita a quatro setores específicos, entre os quais não se encontra o educacional. Por fim, considerando a propriedade estatal da terra na China, são estabelecidos os limites ao uso da terra por empresas e indivíduos estrangeiros. Para atividades com fins educacionais, científicos, culturais, de saúde pública e de educação física o prazo limite de uso alcança 50 anos. Enquanto os cronogramas dos acordos com Cingapura e Peru não trazem limitações sobre tratamento nacional, o mesmo não acontece nos acordos com Chile e com Nova Zelândia, que, em relação ao modo 3, excluem do alcance da liberalização todos os subsídios existentes para prestadores domésticos de serviços nos setores de serviços audiovisuais, médicos e de aviação. Os acordos com o Chile e o Paquistão vão mais longe e estendem tal limitação a todos os subsídios existentes para prestadores domésticos em todos os setores listados nos compromissos específicos dos respectivos acordos e todo novo setor e subsetor que venha a ser incluído no cronograma em futuras negociações.

Em seus cronogramas de liberalização, a China formula seus compromissos e limitações de maneira uniforme sobre todos os subsetores educacionais, entre eles a educação superior. Assim, compromissos no modo 1 não são consolidados nem quanto a acesso a mercados nem quanto ao tratamento 
nacional, enquanto o modo 2 é liberalizado sem limitações em relação a ambas as obrigações. No modo 3 (presença comercial), no campo do acesso a mercados, é liberado o estabelecimento de escolas conjuntas, com propriedade majoritária do capital estrangeiro permitida. No entanto, a esses não são oferecidos compromissos de tratamento nacional, não consolidados no cronograma de liberalização. Nos acordos com Chile, Cingapura, Paquistão, Peru e Costa Rica, a China apresenta compromissos no modo 4, permitindo que prestadores estrangeiros individuais de serviços educacionais possam ingressar no país para fornecer serviços educacionais quando convidados ou empregados por instituições educacionais chinesas. Para tanto, devem possuir no mínimo o grau de bacharel e um título ou certificado profissional, com dois anos de experiência profissional.

O Peru traz para o seu cronograma de compromissos limitações a todos os setores consolidados que correspondem às reservas feitas nos acordos já analisados. De modo geral, referem-se à propriedade de terras e imóveis localizados em uma faixa de até $50 \mathrm{~km}$ da fronteira peruana, e à possibilidade de manter ou adotar medidas que concedam direitos ou preferências para minorias, assim como medidas direcionadas à educação pública. O país somente consolida compromissos de liberalização de serviços de educação superior em relação às obrigações de tratamento nacional no modo 3, de forma plena. De resto, não há qualquer compromisso de acesso a mercados para todos os modos de serviços, nem de tratamento nacional para os modos 1, 2 e 4. Em sentido contrário, a Nova Zelândia apresenta compromissos plenos nos modos 1,2 e 3 .

\subsubsection{Acordos preferenciais de comércio da União Europeia}




\begin{tabular}{|c|c|c|c|c|c|}
\hline $\begin{array}{l}\text { Parceiro } \\
\text { comercial }\end{array}$ & Acordo & 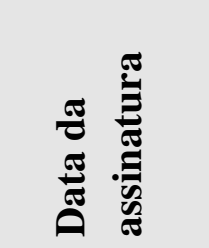 & 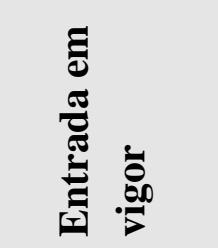 & : & 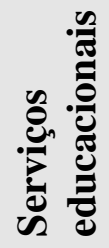 \\
\hline Chile & Chile-European Community Association Agreement & 18.11.2002 & 01.02 .2003 & $\mathrm{X}$ & UE \\
\hline $\begin{array}{l}\text { Coreia do } \\
\text { Sul }\end{array}$ & $\begin{array}{l}\text { Free Trade Agreement between the European Union } \\
\text { and the Republic of Korea }\end{array}$ & 06.10 .2010 & 01.07 .2011 & $\mathrm{X}$ & $\mathrm{X}$ \\
\hline $\begin{array}{l}\text { Colômbia } \\
\text { e Peru }\end{array}$ & $\begin{array}{l}\text { Trade Agreement between the European Union and } \\
\text { Colombia and Peru }\end{array}$ & 26.06.2012 & 01.03 .2013 & $\mathrm{X}$ & $\mathrm{X}$ \\
\hline $\begin{array}{l}\text { América } \\
\text { Central }\end{array}$ & $\begin{array}{l}\text { European Union-Central America Association } \\
\text { Agreement }\end{array}$ & 29.06.2012 & 01.08 .2013 & $\mathrm{X}$ & $\mathrm{X}$ \\
\hline
\end{tabular}




\begin{tabular}{|c|c|c|c|c|c|c|c|c|c|}
\hline & 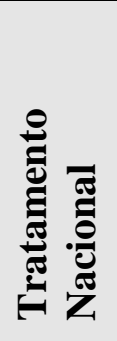 & 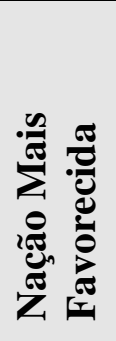 & 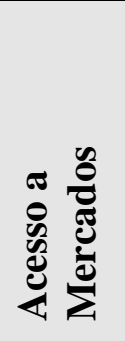 & 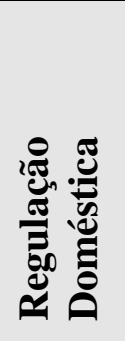 & 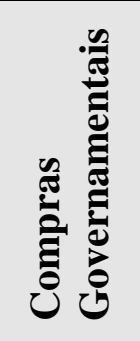 & 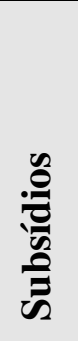 & 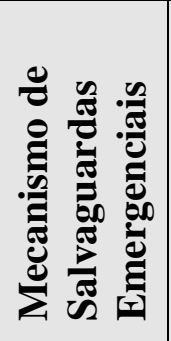 & 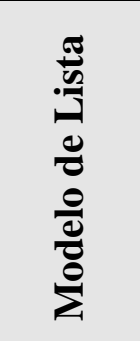 & 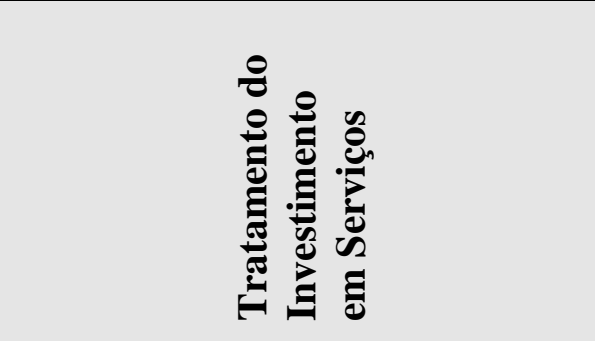 \\
\hline $\begin{array}{l}\text { União Europeia - } \\
\text { Chile }\end{array}$ & $\mathrm{X}$ & & $\mathrm{X}$ & $\mathrm{X}$ & $\begin{array}{l}\text { capítulo } \\
\text { próprio }\end{array}$ & & & positiva & capítulo de serviços (presença comercial) \\
\hline $\begin{array}{l}\text { União Europeia - } \\
\text { Coreia do Sul }\end{array}$ & $\mathrm{X}$ & $\mathrm{X}$ & $X$ & $\mathrm{X}$ & $\begin{array}{l}\text { capítulo } \\
\text { próprio }\end{array}$ & & & positiva & capítulo de estabelecimento \\
\hline $\begin{array}{l}\text { União Europeia - } \\
\text { Colômbia e Peru }\end{array}$ & $\mathrm{X}$ & & $X$ & $\mathrm{X}$ & $\begin{array}{l}\text { capítulo } \\
\text { próprio }\end{array}$ & & & positiva & capítulo de estabelecimento \\
\hline $\begin{array}{l}\text { União Europeia - } \\
\text { América Central }\end{array}$ & $\mathrm{X}$ & & $\mathrm{X}$ & & $\begin{array}{l}\text { capítulo } \\
\text { próprio }\end{array}$ & & & positiva & capítulo de estabelecimento \\
\hline
\end{tabular}


A União Europeia historicamente se destaca tanto pelo número de acordos preferenciais de comércio quanto pela adoção de um amplo arsenal de disposições que envolvem temas de direitos humanos ${ }^{489}$ em seus acordos comerciais. No período pós-guerra, a Europa exerceu um papel central na proliferação desses acordos. Inicialmente estabelecida como Comunidade Econômica Europeia, em 1957, hoje, a UE possui a rede mais extensa de acordos regionais de comércio entre os membros da OMC. Ao mesmo tempo, diferente dos Estados Unidos, os europeus não utilizaram, no entanto, um modelo padrão para seus acordos regionais, o que faz com que sua rede de acordos seja caracterizada por diferentes agendas de liberalização e regras comerciais. ${ }^{490}$ A possibilidade desses acordos serem negociados de maneira flexível para servir à União e seus parceiros de acordo com cada caso específico dá ensejo a tipologias distintas para a classificação dos acordos.

São ao menos sete níveis diferentes de integração, a começar pela própria UE. Com a Área Econômica Europeia, o mercado comum da UE é estendido a Noruega, Islândia e Liechtenstein, embora cada Estado-membro mantenha sua tarifa externa separada, além de a política agrícola comum não se estender a AEE. Mesmo que somente em torno de produtos industriais, foram acordadas Uniões Aduaneiras com Andorra, Chipre, Malta e Turquia. De outro lado, governados pelo então denominado "Barcelona Process" Euro-Mediterrâneos preveem uma relação especial da UE com os doze parceiros mediterrâneos localizados no sul e no leste da região. Ainda, a UE possui uma rede de acordos que concede preferências unilaterais, tanto ao Grupo de Países da África, Caribe e Pacífico (ACP), por meio do Acordo de Cotonou, quanto aos demais países em desenvolvimento, sob o Sistema Geral de Preferências (SGP) da Enabling Clause

\footnotetext{
${ }^{489} \mathrm{Um}$ dos instrumentos mais eficazes da UE para promover os direitos humanos externamente é o uso da proteção dos direitos humanos como uma qualificação para a adesão ao bloco. O Tratado da UE baseia a adesão de novos Estados-Membros na aderência aos princípios comuns de liberdade, democracia, respeito pelos direitos humanos e liberdades fundamentais, e Estado de Direito. Essas qualificações devem ser cumpridas antes que a adesão seja concedida (SCHEFER, Krista Nadakavukaren. The Use of Trade Instruments in the Pursuit of Human Rights: European Foreign Policy. In: ABBOTT, Frederick, BREINING-KAUFMANN, Christine, COTTIER, Thomas (edit.). International Trade and Human Rights: Foundations and Conceptual Issues. The University of Michigan Press, 2006, p. 308).

${ }^{490}$ AHEARN, Raymond J. Europe's Preferential Trade Agreements: Status, Content, and Implications. Congressional Research Service, March 2010, p. 3.

${ }^{491}$ Ver http://eeas.europa.eu/euromed/barcelona en.htm.
} 
da OMC. ${ }^{492}$ Por fim, o bloco tem acordos de livre comércio típicos, com países e regiões mais distantes, sendo o objetivo central europeu nesse caso neutralizar a discriminação potencial contra os exportadores e investidores europeus ou assegurar benefícios comerciais através de acesso preferencial aos mercados estrangeiros.

O reposicionamento das posturas negociadoras globais - uma inflexão no cenário multilateral e a busca de caminhos bilaterais - gerou consequências na política comercial da União Europeia. A Comissão Europeia ficou responsável por propor uma nova geração de acordos bilaterais de livre comércio com parceiros considerados estratégicos. A nova estratégia foi consolidada no documento "Global Europe $^{\text {,493 }}$, cuja maior inovação foi dar fim à moratória ao lançamento de novos acordos dessa natureza, que se estendeu de 1999 a 2006. ${ }^{494}$ Além das dificuldades no avanço da agenda multilateral, foram decisivos para a retomada das negociações desse tipo de acordo, os desenvolvimentos na política comercial dos Estados Unidos $^{495}$, o crescimento econômico na Ásia e a conclusão de acordos que acompanharam esse processo, bem como as mudanças domésticas dentro da própria União Europeia, como, por exemplo, a saída de Pascal Lamy, figura à qual estava ligada a moratória sobre novos acordos dessa natureza. ${ }^{496}$

A escolha estratégica de selecionar países específicos para negociar pode ser lida como uma superação da abordagem região-região, perseguida como prioridade pela Comissão nas negociações anteriores. A percepção de que uma abordagem bilateral oferece melhores resultados leva a que somente se continue a negociar em bloco com o Mercosul e com o Conselho de Cooperação do Golfo. Como a complexidade das dinâmicas internas pode reduzir o nível de ambição das partes enquanto os países buscam alcançar um mínimo denominador comum para o bloco, a

\footnotetext{
${ }^{492}$ PANAGARIYA, Avind. EU Preferential Trade Policies and Developing Countries. The World Economy, v. 25, n. 10, p. 1415-1432, November 2002.

${ }^{493}$ European Commission. Global Europe: Competing in the World - A Contribution to the EU's Growth and Jobs Strategy. Brussels: European Commission, 2006.

${ }^{494}$ European Commission. Report on progress achieved on the Global Europe strategy, 2006-2010. Commission Staff Working Document. Brussels: European Commission, 2010, p. 4-5

495 "The EU also tends to see itself as being in competition with the US in setting the agenda for the terms and conditions for future multilateral trade negotiations on an increasing wider range of 'behind the border' trade-related issues, such as competition law, standards, public procurement, investment codes and rights of establishment, and FTAs are envisaged as a means of establishing EU procedures as international norms" (McQUEEN, Matthew. The EU's Free-trade Agreements with Developing Countries: A Case of Wishiful Thinking? The World Economy, v. 25, n. 9, 2002, p. 1383-1384).

${ }^{496}$ WOOLCOCK, Stephen. European Union Policy Towards Free Trade Agreements. ECIPE Working Paper, n. 3, 2007, p. 5. Disponível em: http://www.ecipe.org/publications/ecipe-workingpapers/european-union-policy-towards-free-trade-agreements.
} 
Comissão Europeia passou a buscar celebrar acordos bilaterais com alguns países latino-americanos e a relançar as negociações com os países da ASEAN em bases individuais, a começar por Cingapura. A partir dessa perspectiva, os principais critérios elaborados para a definição dos novos parceiros foram o potencial de mercado (tamanho e crescimento) e o nível de proteção contra os interesses exportadores da União Europeia (barreiras tarifárias e não-tarifárias). Sendo assim, a redefinição dos objetivos determina o lançamento de novos acordos comerciais sob critério econômico, buscando maior envolvimento com as principais economias e regiões emergentes - com reiteradas referências ao Brasil, a China, a Índia e aos países do Sudeste Asiático -, e o enforcement das regras de comércio internacional.

Até completar o acordo de livre comércio com a Coreia da Sul, os acordos preferenciais de comércio da União Europeia permaneciam caracterizados pela diferenciação, flexibilidade e uma ambição relativamente modesta em termos de abertura de mercados, especialmente se comparado com os Estados Unidos. A abordagem variava tanto em termos de disposições quanto de compromissos, de acordo com diferentes fatores, incluindo o nível de desenvolvimento de seus parceiros comerciais, o quão importantes eram para a segurança europeia, e em quais setores eles constituíam um desafio de concorrência. ${ }^{497}$ Sendo assim, a opção nesse trabalho foi pela análise do acordo com o Chile, até a estratégia do Global Europe um dos mais avançados em termos de liberalização, e os acordos posteriores com Coreia do Sul, Colômbia e Peru, e América Central, os dois últimos assinados em 2012 e com entrada em vigor no ano de 2013.

Mesmo nesses acordos, o tratamento de serviços nos acordos europeus é menos ambicioso do que na abordagem estadunidense, a começar com a permanência do modelo da lista positiva, que proporciona a flexibilidade necessária para excluir setores sensíveis tanto para os membros do bloco quanto para seus parceiros comerciais. ${ }^{498}$ Os acordos europeus anteriores reafirmavam as obrigações do GATS e o compromisso em avançar na liberalização do comércio de serviços, como no Acordo União Europeia-África do Sul, mas sem uma abertura efetiva. O acordo com o Chile dá um passo adiante nesse sentido, mas seguindo com o padrão muito

\footnotetext{
${ }^{497}$ AHEARN, Raymond J. Europe's Preferential Trade Agreements: Status, Content, and Implications, p. 13-14.

${ }^{498}$ AHEARN, Raymond J. Europe's Preferential Trade Agreements: Status, Content, and Implications, p. 16.
} 
próximo ao do GATS, com o tratamento dos investimentos em serviços pelo próprio capítulo de serviços como modo 3 (presença comercial). O acordo com a Coreia do Sul inova ao ir além dos compromissos existentes no âmbito do GATS, integrando o investimento em serviços (modo 3) à liberalização dos investimentos, e avançando sobre um espectro superior de setores de serviços, tendência que é repetida nos acordos com Colômbia e Peru, e América Central.

O Acordo União Europeia-Coreia do Sul abrange em um só capítulo as disposições sobre comércio de serviços, estabelecimento e comércio eletrônico. Nesse quadro, enquanto os modos 1 e 2 são tratados como comércio transfronteiriço de serviços em uma seção à parte, o modo 3 (presença comercial) é tratado como investimento em serviços na seção relativa ao estabelecimento. Para os fins do referido capítulo, estabelecimento significa a constituição, aquisição ou manutenção de uma pessoa jurídica, ou a criação ou manutenção de uma subsidiária ou escritório de representação no território de uma parte para fins de desempenhar atividade econômica. Assim, ainda que com a lista positiva, é garantida uma abordagem comum ao modo 3 e demais formas de investimentos. O modo 4 não está incluído no capítulo, que inclui uma seção que dá conta somente da presença temporária de pessoas físicas para negócios. Cada um dos campos - comércio transfronteiriço de serviços e estabelecimento - conta com regras de tratamento nacional e acesso a mercados próprias, enquanto a parte final do capítulo conjunto prevê uma série de regras aplicáveis a ambos: reconhecimento mútuo, transparência e regulação doméstica.

Da mesma forma, os compromissos em relação ao comércio transfronteiriço de serviços, e estabelecimento são elaborados em dois cronogramas distintos onde, em cada um deles, de um lado, são especificados os setores e subsetores liberalizados, e, de outro, são inseridas as reservas dos países, em uma só coluna que se refere ao mesmo tempo tanto às obrigações de acesso a mercados quanto às de tratamento nacional. Nos dois cronogramas os compromissos específicos abrangem tão somente os serviços educacionais com financiamento privado, o que repete a prática de todos os acordos de excluírem de sua incidência a educação pública.

O primeiro cronograma considera os compromissos em relação à prestação transfronteiriça (modo 1) e ao consumo no exterior (modo 2). No campo dos compromissos horizontais, quando existentes, as limitações dizem respeito à 
compra de terras e bens imóveis por estrangeiros, sendo vedada ou sujeita a condições. Entre os países da União Europeia, Áustria, Bulgária, Chipre, Eslováquia, Finlândia, Malta, República Tcheca, Romênia e Suécia não consolidam qualquer compromisso em ambos os modos no subsetor da educação superior. Por sua vez, França e Itália estabelecem condições de nacionalidade no acordo com a Coreia do Sul, enquanto deixam de oferecer qualquer compromisso em relação aos modos 1 e 2 nos acordo com Colômbia e Peru, e com a América Central.

De outro lado, em relação ao estabelecimento, que inclui os investimentos em serviços, o segundo cronograma traz os setores e subsetores liberalizados e as respectivas reservas. No plano horizontal, as reservas que impactam de forma geral sobre todos os setores e subsetores liberalizados estão concentradas sobre bens imóveis, serviços de utilidade pública, tipos de estabelecimento e investimentos. Áustria, Bulgária, Chipre, Dinamarca, Eslováquia, Estônia, Finlândia, Hungria, Irlanda, Itália, Letônia, Lituânia, Malta, Polônia, República Tcheca, Romênia e Suécia vedam ou sujeitam a condições a compra de terras e bens imóveis por investidores estrangeiros. Em segundo lugar, em todos os países do bloco, atividades econômicas consideradas como sendo de utilidade pública em um nível nacional ou local podem ser sujeitas a monopólios públicos ou a direito exclusivos concedidos a operadores privados. Novamente, em todos os países do bloco, o tratamento concedido às subsidiárias estrangeiras formadas de acordo com a lei dos Estados Membros da União Europeia e tendo seu escritório registrado, administração central ou principal local de negócios dentro da União Europeia não se estende às filiais ou agências estabelecidas nos Estados Membros por companhias da Coreia do Sul, Colômbia e Peru, e da América Central. Ainda sobre os tipos de estabelecimento, Bulgária, Eslováquia, Eslovênia, Estônia, Finlândia, Itália, Polônia, Romênia e Suécia inserem regras extras no cronograma. Por fim, Bulgária, Espanha, França, Finlândia, Hungria e Itália impõem reservas sobre investimentos, em geral, sobre investimentos de governos ou empresas públicas estrangeiros, investimentos em companhias recém privatizadas, e investimentos estrangeiros superiores a um terço do capital votante de empresas domésticas.

No que toca ao estabelecimento no setor educacional, os compromissos são feitos conjuntamente nos setores do ensino primário, do ensino secundário e do ensino superior, ou seja, a estes valem as mesmas reservas feitas ao estabelecimento 
de investimentos em serviços. De maneira geral e ampla, a primeira reserva diz respeito a todos os países do bloco, e insere a participação de operadores privados na rede educacional sujeita à concessão. A Áustria não consolida compromissos para serviços de educação superior prestados via transmissão de rádio ou televisão. A Bulgária não consolida compromissos para a prestação de serviços de educação primária, secundária e superior por pessoas físicas e associações estrangeiras. Eslováquia e República Tcheca não consolidam a compromissos em educação superior, enquanto Chipre, Finlândia, Malta, Romênia e Suécia não consolidam compromissos em qualquer desses subsetores da educação. De resto, todos os demais países do bloco deixam sujeito o estabelecimento em matéria de ensino superior somente às reservas horizontais, aplicáveis a qualquer setor e subsetor liberalizado.

Essas mesmas reservas se repetem no acordo com a Colômbia e o Peru, e no acordo com a América Central, porém se somam outras a elas nesses dois acordos posteriores. A Grécia também deixa de consolidar qualquer compromisso em educação superior. A Espanha e Itália estabelecem provas de necessidade para a abertura de universidades privadas, cujo critério principal é a população e a densidade de estabelecimentos existentes. A Hungria e a Eslováquia se reservam ao direito de limitar por meio das autoridades centrais o número de instituições sendo estabelecidas. Por fim, a Eslovênia apresenta uma condição de nacionalidade para a diretoria das universidades.

No acordo com a União Europeia, a Coreia do Sul repete os seus compromissos feito no Acordo Índia-Coreia do Sul em relação à educação superior, inclusive o tratamento dos quatro modos de serviços no mesmo cronograma. É feita uma única alteração, ao incluir como reserva em relação às obrigações de tratamento nacional no modo 3 a necessidade de ter na diretoria das instituições de ensino superior privado ao menos $50 \%$ de nacionais sul-coreanos. No acordo União Europeia-Colômbia e Peru, em estabelecimento, o Peru insere as mesmas reservas horizontais inseridas nos seus outros acordos, além de não consolidar compromissos relacionados às obrigações de tratamento nacional quanto à concessão de subsídios. No âmbito dos compromissos no setor educacional, em relação a todos os subsetores, não consolida compromissos de acesso a mercados, enquanto consolida e não apresenta reservas às obrigações de tratamento nacional. Já a Colômbia, não inclui 
nenhum compromisso em educação superior, o mesmo que fez o Chile no seu acordo com a União Europeia.

Em um contexto no qual o Acordo União Europeia-Chile segue de maneira ampla o modelo do GATS, os compromissos específicos e as limitações a acesso a mercados e ao tratamento nacional são feitas modo a modo em duas colunas principais. Boa parte das limitações que se referem a todos os setores e subsetores liberalizados antecipam as reservas que depois foram repetidas nos acordos com Coreia do Sul, Colômbia e Peru, e América Central, salvo as limitações ao tratamento nacional quanto à concessão de subsídios, que nos demais acordos mais recentes já são excluídas de pronto da incidência do capítulo sobre serviços transfronteiriços e estabelecimento. No campo da educação superior, Áustria, Finlândia e Suécia não consolidaram qualquer compromisso em nenhum dos modos de serviços. No modo 2 , em acesso a mercados, e nos modos 1, 2 e 3, em tratamento nacional, essa é a única reserva incluída pela União Europeia. Em relação às obrigações de acesso a mercados, no modo 1, a França estabelece condições de nacionalidade para o acesso de estrangeiros; no modo 3, Espanha e Itália exigem provas de necessidade para a abertura de universidades privadas, enquanto a Grécia não consolida compromissos em relação a instituições que concedam títulos reconhecidos pelo Estado; e no modo 4, não são consolidados compromissos quanto à entrada temporária de professores estrangeiros, salvo por Alemanha, Bélgica, Dinamarca, Espanha, França e Luxemburgo, sujeita a limitações específicas. 


\section{CONSIDERAÇÕES FINAIS}

Esta tese abordou o desenvolvimento da regulação internacional relativa ao comércio de serviços educacionais, em especial os compromissos de liberalização e as respectivas limitações/reservas apresentadas pelos países em determinados acordos preferenciais de comércio. O objetivo foi determinar um parâmetro do atual nível de liberalização comercial da educação superior no plano global, de modo que sua compatibilidade com o direito à educação pudesse ser criticamente analisada, assim como os seus possíveis impactos sobre a regulação da educação superior no Brasil. Ao regulador educacional doméstico é revelada a proliferação de regras internacionais em torno da comercialização da educação, em uma arena até então estranha ao seu campo de atuação original. Já ao trabalhar com os desafios e problemas do processo de fusões e aquisições no setor educacional, além das características específicas da educação superior como um bem público e direito humano, traz-se ao direito do comércio internacional e seus operadores um conjunto distinto de valores que devem ser levados em consideração.

O capítulo 1 trouxe uma leitura da expansão da educação superior privada com fins lucrativos no Brasil a partir de depoimentos de atores que vivenciam o processo de consolidação do setor em diferentes instâncias e sob distintas perspectivas. Se, por um lado, a capilaridade que os investimentos e investidores estrangeiros alcançam dentro do sistema doméstico privado de educação superior, com o controle de um número cada vez maior de instituições educacionais - via transferência de mantença ou participação acionária - e a ausência de limites ao ingresso do capital estrangeiro no setor educacional permitem que se afirme que o "mercado" nacional encontra-se relativamente liberalizado; por outro lado, as entrevistas concedidas e o trabalho de pesquisa realizado contrariam em ao menos dois pontos o discurso comumente apresentado em relação ao processo de transnacionalização da educação superior e os grupos educacionais estrangeiros.

Primeiro, as expectativas de que a transnacionalização do setor represente também um movimento de instituições educacionais estrangeiras de prestígio em direção a países em desenvolvimento não são cumpridas. Os dados reforçam a constatação de que os grupos educacionais que mais se aproveitam desse processo e com interesse de ingressar no país buscam eminentemente o lucro, já que 
provenientes do setor privado lucrativo. Instituições de prestígio, quando interessadas em estabelecer vínculos com o país, o fazem através dos canais tradicionais de cooperação acadêmica com instituições domésticas ou de instrumentos não formais para a captação de alunos e tentativa de inclusão de seus programas em políticas governamentais. Ao mesmo tempo, como os investidores educacionais estrangeiros ingressaram no país simplesmente se valendo da ausência de restrições a sua entrada, não se vê no Brasil qualquer planejamento específico em torno do papel que se pretenda conceder ao capital educacional estrangeiro. A atitude brasileira diferenciase, por exemplo, de países do Sudeste Asiático, como Cingapura e Malásia, que procuram constituir polos exportadores de serviços educacionais por intermédio de políticas desenhadas para atrair instituições e programas educacionais estrangeiros de alta qualidade e prestígio. Nos países citados, os acordos comerciais assinados na sequência, longe de serem os responsáveis pela atração dos investimentos, simplesmente consolidaram um marco regulatório adaptado à nova realidade criada por seus governos.

Em segundo lugar, os depoimentos coletados colocam em xeque a ideia de que o investimento estrangeiro no setor privado educacional doméstico possa ser necessariamente pior para a qualidade da educação do que o modelo educacional oferecido pelos grupos nacionais. A entrada dos investimentos estrangeiros no setor educacional brasileiro acompanhou boa parte do processo de consolidação do setor que se estende ao menos desde o início dos anos 2000 no Brasil, cumprindo um papel na formação de uma cultura de gestão profissional e no reforço de um sistema de educação de massa, que ampliou o acesso ao ensino superior para uma faixa da população antes fora dos bancos escolares, mas que também apresenta significativos decréscimos na qualidade da educação oferecida e na valorização dada aos profissionais docentes. Ainda que partes do mesmo processo de comercialização da educação, que assume como valor central e objetivo imediato a cultura de servir às demandas do mercado e da busca do lucro, os grupos educacionais estrangeiros no Brasil e os grupos educacionais domésticos com capital aberto na bolsa de valores são avaliados de forma distinta nas entrevistas realizadas para o trabalho. Enquanto os primeiros permitiriam uma liberdade maior e menor grau de padronização de currículos e material didático, com a manutenção das instituições adquiridas, mesmo que inseridas dentro de um contexto empresarial global e hierárquico; os últimos 
trariam uma verticalização mais forte, inserindo-se de maneira mais aguda em um contexto de oferta de educação em massa, deixando de lado a cultura acadêmica local.

Mais do que a questão em torno da nacionalidade dos grupos que controlam as instituições, o problema estaria no modelo de ensino, com o perigo de um grande número de estabelecimentos tornar-se fábricas de diplomas, sem preocupações e investimentos adequados em ensino, pesquisa e extensão. Para se manterem ao mesmo tempo lucrativas e autorizadas a permanecer funcionando, algumas instituições atuam no limite das normas que regulam a educação superior, levando o impacto da aquisição de uma instituição por um desses grupos a variar de acordo com o patamar de qualidade no qual aquela se encontrava antes da operação. Assim, instituições de baixa qualidade e/ou em condições falimentares enfrentariam uma melhora com um processo de padronização, enquanto instituições melhor posicionadas sofreriam ao se adaptar a um padrão de qualidade mais baixo e a um nível de uniformização que desconsideraria sua cultura organizacional e características particulares.

Considerando, então, que o Brasil não possui compromissos de liberalização comercial de serviços educacionais em qualquer acordo internacional de comércio, assim como não impõe limites aos investimentos estrangeiros no setor, não se pode atribuir aos instrumentos do direito do comércio internacional os efeitos diretos do processo de comercialização da educação superior no país. No entanto, tal processo e o consequente número de fusões e aquisições formam parte também de um mesmo movimento de comercialização da educação em escala global, com o desenho de regras internacionais no âmbito do GATS, junto à OMC, e nos acordos preferenciais de comércio que seguem a este. Além dos efeitos simbólicos, os acordos comerciais trazem um modelo específico de transnacionalização da educação, com a definição das classificações e conceitos em torno dos quais o comércio de serviços educacionais foi estruturado.

O GATS e os acordos preferenciais de comércio que seguem o mesmo modelo para o desenho de seus capítulos sobre o comércio de serviços estão amparados na ideia de flexibilidade e de liberalização progressiva, com a possibilidade dos países consolidarem paulatinamente compromissos nos setores que entenderem por bem liberalizar, por vezes reiterando o marco regulatório doméstico ou inclusive apresentando compromissos inferiores à este marco. Porém, ainda que a 
adoção de compromissos de acesso a mercados e tratamento nacional dependa da decisão voluntária dos Estados, as demais obrigações dos acordos, como tratamento de nação mais favorecida, regulação doméstica e requisitos de transparência, incidem também sobre setores não incluídos nos cronogramas de liberalização. Ao mesmo tempo, a flexibilidade para a adoção de compromissos específicos não corresponde necessariamente a uma efetiva liberdade dos Estados no âmbito de negociações comerciais, sobretudo em um contexto que oponha países desenvolvidos e países em desenvolvimento.

Por outro lado, os acordos preferenciais de comércio com uma abordagem de lista negativa aprofundam significativamente a liberalização comercial, com a necessidade de uma amplo conhecimento de todos os setores e subsetores e formação prévia das posições negociadoras, pois o que não se encontra expressamente excepcionado, é incluído de forma automática na abrangência do acordo. Mais do que isso, nesse modelo, em geral os signatários estão sujeitos a um mecanismo de solução de controvérsias tipicamente desenhado para os investidores estrangeiros em tribunais arbitrais internacionais, em um sistema investidor-Estado.

As manifestações sobre o tema no Brasil, tanto acadêmicas quanto pelos setores público e privado, intensificam-se a partir do ano 2000, com os pedidos e ofertas de liberalização dos serviços educacionais na OMC. Naquele momento, a posição do MEC nas primeiras ocasiões em que ao Brasil é solicitada a oferta de compromissos de acesso a mercados e tratamento nacional em relação aos serviços educacionais, e nas diversas vezes em que seus representantes se manifestaram quanto à inclusão da educação em acordos de comércio, parece ser oposta à prática efetiva na esfera doméstica. Nela, como referido, não existem limites à presença do capital estrangeiro no setor, e o segmento privado com fins lucrativos cresceu exponencialmente nas duas últimas décadas em um amplo fenômeno de comercialização da educação superior. Na esfera internacional, o MEC foi eficiente ao articular junto ao MRE a posição do país contrária à consolidação de qualquer compromisso de liberalização do comércio de serviços educacionais. A manutenção ou não dessa postura pelo Ministério hoje é um aspecto que merecerá pesquisa futura específica.

A parte final da tese analisa as disciplinas, os compromissos e as limitações/reservas sobre os serviços educacionais em acordos preferenciais de 
comércio dos quais fazem parte os Estados Unidos, Austrália, Chile, Cingapura, Índia, China e União Europeia. Continuidades e descontinuidades colocam-se entre os acordos. Os Estados Unidos, a Índia e a China parecem capazes de garantir acordos mais padronizados e ajustados aos seus interesses específicos Os acordos norteamericanos próximos ao modelo trazido pelo NAFTA, de lista negativa e com o tratamento de investimentos em serviços pelo capítulo de investimentos, e os acordos indianos e chineses no outro polo, com um modelo próximo à estrutura do GATS. O Chile, quando possível, adota um modelo de acordo semelhante àqueles firmados pelos Estados Unidos. Austrália e Cingapura apresentaram mudanças nas suas posturas ao longo do período considerado, enquanto a União Europeia, com vários níveis de acordo, alcança um padrão mais próximo aos acordos de livre comércio modernos a partir do Acordo UE-Coreia do Sul. Em relação aos serviços educacionais, os acordos parecem consolidar um regime menos liberal do que os respectivos regimes domésticos, mantendo ainda espaços para políticas públicas que protegem não só o setor educacional público, mas, em diferentes níveis, também o setor privado. Vários destes restringem, inclusive, o acesso a mercados somente a instituições educacionais sem fins lucrativos, ao mesmo tempo em que estabelecem uma série de limitações que dizem respeito também ao financiamento público educacional.

Dessa forma, a análise das limitações e reservas impostas pelos Estados em seus cronogramas e anexos mostra medidas muito mais restritivas do que aquelas existentes no marco regulatório brasileiro, de modo que, ou já estamos muito mais liberalizados nesse sentido, e/ou os países consolidaram compromissos que sequer representam o status quo regulatório em seus respectivos territórios. Mais do que não restringir o acesso ao mercado a prestadores estrangeiros de educação superior - tanto instituições privadas sem fins lucrativos quanto com fins lucrativos -, a legislação educacional brasileira parece não impor nenhuma forma de tratamento discriminatório aos prestadores estrangeiros em relação aos prestadores domésticos em situações semelhantes.

Não obstante, não se trata de saber se o setor da educação superior está preparado para uma liberalização comercial em acordos internacionais; a questão é se ela é desejável e, mais adiante, a de saber quem deveria ditar os interesses centrais nestas negociações. Ainda que se reconheça uma demanda histórica por educação 
superior não suprida pelo setor público, o investimento privado no país já se deu por canais domésticos e mesmo estrangeiros nos últimos anos, sem que fossem necessários acordos de comércio na matéria. Assim, a ausência deles não constitui um obstáculo. A retirada de barreiras comerciais atende sobretudo aos interesses do setor privado lucrativo estrangeiro ou até mesmo do setor privado lucrativo doméstico com eventuais interesses exportadores. Não há que se falar de interesses próprios do Estado, a não ser que este assuma como seus os interesses dos grupos economicamente dominantes no interior do seu território, ou seja, dos principais grupos educacionais privados brasileiros e das entidades representativas do setor privado com fins lucrativos.

Sob a perspectiva do regulador educacional doméstico, considerando que o fluxo de investimentos estrangeiros para o Brasil é constante e crescente desde o início dos anos 2000, mesmo sem acordos comerciais e, inclusive, sem acordos de investimentos; considerando que a natureza das empresas educacionais interessadas nesse modelo de regulação e também em investir nas economias em desenvolvimento não corresponde às expectativas de ingresso de universidades de prestígio; e considerando que a proteção dos interesses internacionais das empresas nacionais de educação não pode se dar em detrimento da manutenção do direito de regular do Estado, sob qualquer forma e em qualquer grau, não parecem existir vantagens claras ou mesmo qualquer necessidade de assumir compromissos educacionais dessa natureza.

Apesar do grau já existente de abertura comercial, o setor educacional demanda uma liberdade regulatória inerente a um bem público, em especial para medidas emergenciais e controle de qualidade. Questões relacionadas à internacionalização da educação podem ser solucionadas em outros fóruns, sob uma perspectiva essencialmente educacional, por meio de canais tradicionais de cooperação educacional e acordos bilaterais específicos, para o reconhecimento de diplomas, por exemplo. Não há a necessidade de um fórum comercial para tanto. Deve-se buscar a internacionalização da educação superior como meta, mas não necessariamente a transnacionalização do setor. 


\section{REFERÊNCIAS BIBLIOGRÁFICAS}

ADLUNG, Rudolf. Services liberalization from a WTO/GATS perspective: in search of volunteers. World Trade Organization Staff Working Paper ERSD-2009-05, Fev. 2009. Disponível em: <http://ssrn.com/abstract=1345018>.

ADLUNG, Rudolf. Services Trade Liberalization from Developed and Developing Country Perspectives. In: SAUVÉ, Pierre and STERN, Robert M. (edit.). GATS 2000: new directions in services trade liberalization. Washington: The Brookings Institution, 2000, p. 112-130.

ADLUNG, Rudolf; MOLINUEVO, Martin. Bilateralism in Service Trade: Is There Fire Behind the (BIT-)Smoke? World Trade Organization Staff Working Paper ERSD-2008-01, Jan. 2008. Disponível em: http://ssrn.com/abstract=1086304.

ADLUNG, Rudolf; ROY, Martin. Turning hills into mountains? Current commitments under the gats and prospects for change. World Trade Organization (Staff Working Paper ERSD-2005-01), Mar. 2005. Disponível em: http://ssrn.com/abstract=922058.

AGUIAR, Márcia Ângela. Sistemas Universitários na América Latina e as Orientações Políticas de Agências Internacionais. In: CATANI, Afrânio Mendes (org.). Novas Perspectivas nas Políticas de Educaçao Superior na América Latina no Limiar do Século XXI. Campinas, SP: Editora Autores Associados, 1998, p. 103-115.

AHEARN, Raymond J. Europe's Preferential Trade Agreements: Status, Content, and Implications. Congressional Research Service, Mar. 2010.

ALMEIDA, Wilson Mesquita de. Ampliação do Acesso ao Ensino Superior Privado Lucrativo Brasileiro: um Estudo Sociológico com Bolsistas do Prouni na Cidade de São Paulo. Tese (Doutorado em Sociologia). Universidade de São Paulo, 2012.

ALSTON, Philip. Resisting the Merger and Acquisition of Human Rights by Trade Law: A Reply to Petersmann, European Journal of International Law, v.13, n.4, p. 815-844, 2002.

ALTBACH, Philip G. The Giants Awake: The Present and Future of Higher Education Systems in China and India. In: OECD. Higher Education to 2030, Volume 2: Globalisation. OECD, Centre for Educational Research and Innovation: 2009, p. 179-204.

ALTBACH, Philip G.; KNIGHT, Jane. The Internationalization of Higher Education: Motivations and Realities. Journal of Studies in International Education, v. 11, n. 3/4, p. 290-305, 2007.

ALTBACH, Philip G.; REISBERG, Liz; RUMBLEY, Laura E. Trends in Global Higher Education: Tracking an Academic Revolution - A Report Prepared for the UNESCO 2009 World Conference on Higher Education. Paris: UNESCO, 2009. 
AVILA, Sueli de Fatima Ourique de. Mercantilização do Ensino Superior: as consequências das mudanças produtivas para os docentes de ensino superior. Tese (Doutorado em Políticas Públicas e Formação Humana). Universidade do Estado do Rio de Janeiro, 2010.

BADIN, Michelle Ratton Sanchez. Compromissos assumidos por grandes e médias economias em acordos preferenciais de comércio: o contraponto entre União Europeia e Estados Unidos e China e Índia. In: OLIVEIRA, Ivan Tiago Machado; BADIN, Michelle Ratton Sanchez. Tendências Regulatórias nos Acordos Preferenciais de Comércio no Século XXI: os casos de Estados Unidos, União Europeia, China e Índia. Brasília: IPEA, 2013, p. 41-69.

BAIG, Jose. Fernando Haddad: o ensino superior é um bem público e um direito humano fundamental. In: Boletín Especial IESALC Informa n. 196 - Final da Conferência Mundial de Educação Superior. UNESCO: Instituto Internacional para a Educação Superior na América Latina e Caribe, 2009. Disponível em: http://www.unesco.org.ve/index.php?option=com_content\&view=article\&id=603: $\mathrm{min}$ istro-de-educacion-de-brasil-la-educacion-superior-un-bien-publico-y-un-derechohumano-fundamental\&catid=19:internacional\&Itemid=153.

BALL, Stephen J. Education plc: Understanding private sector participation in public sector education. Abingdon: Routledge, 2007.

BEITER, Klaus Dieter. The Protection of the Right to Education by International Law. Leiden, The Netherlands: Martinus Nijhoff Publishers, 2006.

Berne, 2003, pp. 7-60.

BRENEMAN, David W. Introduction. In: BRENEMAN, David W.; PUSSER, Brian; TURNER, Sarah E. (edit.). Earnings from Learning: The Rise of For-Profit Universities. Albany: State University of New York Press, 2006, p. ix-xv.

BRENEMAN, David W. The University of Phoenix: Icon of For-Profit Higher Education. In: BRENEMAN, David W.; PUSSER, Brian; TURNER, Sarah E. (edit.). Earnings from Learning: The Rise of For-Profit Universities. Albany: State University of New York Press, 2006, p. 71-92.

BRENEMAN, David W.; PUSSER, Brian; TURNER, Sarah E. The Contemporary Provision of For-Profit Higher Education: Mapping the Competitive Market. In: BRENEMAN, David W.; PUSSER, Brian; TURNER, Sarah E. (edit.). Earnings from Learning: The Rise of For-Profit Universities. Albany: State University of New York Press, 2006, p. 3-22.

BUCCI, Maria Paula Dallari; MELLO, Paula Branco de. Democratização e acesso à educação superior - Parte I, Cadernos Flacso, N7, 2013.

BUCCI, Maria Paula Dallari. O Art. 209 da Constituição 20 anos Depois. Estratégias do Poder Executivo para a Efetivação da Diretriz da Qualidade da Educação Superior. In: SOUZA NETO, Cláudio Pereira; SARMENTO, Daniel; BINENBOJM, Gustavo 
(coord.). Vinte Anos da Constituição Federal de 1998. Rio de Janeiro: Editora Lumen Juris, 2009, p. 781-807.

CARBONARI NETTO, Antônio. In: Debates, Revista da Associação Brasileira de Mantenedoras de Ensino Superior, v. 22, n. 33, p. 44-45;54, Abr. de 2004.

CARVALHO, Cristina Helena Almeida de. A política pública para a educação superior no Brasil (1995-2008): ruptura e/ou continuidade? Tese (Doutorado em Ciências Econômicas). Universidade Estadual de Campinas, 2011.

CATANI, Afrânio Mendes; OLIVEIRA, João Ferreira de. A educação superior. In: OLIVEIRA, Romualdo Portela de; ADRIÃO, Theresa (orgs.). Organização do ensino no Brasil: Níveis e modalidades na Constituição Federal e na LDB. São Paulo: Xamã, 2002, p. 77-88.

CATTANEO, Olivier, ENGMAN, Michael, SÁEZ, Sebastián, e STERN, Robert M. Assessing the potential of services trade in developing countries: an overview. In: CATTANEO, Olivier, ENGMAN, Michael, SÁEZ, Sebastián, e STERN, Robert M. (edits.). International Trade in Services: New Trends and Opportunities for Developing Countries. Washington, D.C.: The World Bank, 2010, pp. 1-28.

CELLI JUNIOR, Umberto. Comércio de Serviços na OMC: Liberalização, Condições e Desafios. Curitiba: Juruá, 2009.

CELLI JUNIOR, Umberto. Políticas de Liberalização do Comércio de Serviços (GATS) com Regulação Redistributiva. Cadernos PROLAM/USP, v. 1, p. 124-148, 2009b.

CELLI JUNIOR, Umberto. Serviços Educacionais no GATS: desafios para o Brasil. Revista Pontes, v. 4, p. 05-06, 2008.

CHANDA, Rupa. Mapping the Universe of Services Disciplines in Asian PTAs. NCCR Trade Regulation Working Paper No 2011/33, Mai. 2011. Disponível em: http://www.nccr-trade.org/fileadmin/user_upload/nccrtrade.ch/wp2/people/WPed5ed\%20Mapping\%20the\%20Universe\%20of\%20Services \%20Disciplines\%20in\%20Asian\%20PTAs\%20_2_-reply\%20may.pdf.

COMIN, Alvaro A.; BARBOSA, Rogério Jerônimo. Trabalhar para estudar: sobre a pertinência da noção de transição escola-trabalho no Brasil, Novos Estudos, n.91, p.75-95, Nov. 2011.

COMISSÃO EUROPEIA. Global Europe: Competing in the World - A Contribution to the EU's Growth and Jobs Strategy. Brussels: European Commission, 2006.

COMISSÃO EUROPEIA. Report on progress achieved on the Global Europe strategy, 2006-2010. Commission Staff Working Document. Brussels: European Commission, 2010.

COTTIER, Thomas; BREINING-KAUFMANN, Christine and KENNETT, Maxine. Liberalisation of Higher Education Services in Switzerland: The Impact of the 
General Agreement on Trade in Services (GATS). In: OFES, Office federal de l'éducation et de la science. Les effets de l'AGCS sur le système éducatif suisse. Berne, 2003, pp. 63-154.

COTTIER, Thomas; PAUWELYN, Joost; BURGI, Elisabeth. Linking Trade Regulation and Human Rights in International Law: An Overview. In: COTTIER, Thomas; PAUWELYN, Joost; BURGI, Elisabeth (edit.). Human Rights and International Trade. New York: Oxford University Press, 2005, p. 1-26.

DESLAURIERS, Jean-Pierre. O delineamento de pesquisa qualitativa. In: POUPART, Jean; DESLAURIERS, Jean-Pierre; GROULX, Lionel-H; LAPERRIÈRE, Anne; MAYER, Robert; PIRES, Álvaro. A pesquisa qualitativa: enfoques epistemológicos e metodológicos. Tradução de Ana Cristina Arantes Nasser. Petrópolis, RJ: Vozes, 2012, p. 127-153.

DEVIDAL, Pierrick. Trading Away Human Rights? The GATS and the Right to Education: a legal perspective. Journal for Critical Education Policy Studies, v. 2, n. 2, p. 1-24, 2004.

DIAS, Marco Antonio Rodrigues. Comercialização no ensino superior: é possível manter a idéia de bem público? Educação e Sociedade, v. 24, n. 84, p. 817-838, 2003.

DOMMEN, Caroline. Human Rights and Trade: Two Practical Suggestions for Promoting Coordination and Coherence. In: COTTIER, Thomas; PAUWELYN, Joost; BURGI, Elisabeth (edit.). Human Rights and International Trade. New York: Oxford University Press, 2005, p. 199-204.

DURHAM, Eunice R. Educação superior, pública e privada. In: BROCK, Colin; SCHWARTZMAN, Simon. Os desafios da educação no Brasil. Rio de Janeiro: Nova Fronteira, 2005, p. 191-233.

FÁVERO, Maria de Lourdes de A. A Dimensão Histórico-Política da Nova Lei de Diretrizes e Bases e a Educação Superior. In: CATANI, Afrânio Mendes (org.). Novas Perspectivas nas Políticas de Educaçao Superior na América Latina no Limiar do Século XXI. Campinas, SP: Editora Autores Associados, 1998, p. 55-73.

FIELDEN, John; LAROCQUE, Norman. The Evolving Regulatory Context for Private Education in Emerging Economies, The World Bank Education Working Paper Series, n. 14, Jun. 2008. Disponível em: http://siteresources.worldbank.org/EDUCATION/Resources/2782001099079877269/547664-1099079934475/5476671135281523948/EWPS14_Private_Education.pdf.

FINK, Carsten; JANSEN, Marion. Services provisions in regional trade agreements: stumbling blocks or building blocks for multilateral liberalization? In: BALDWIN, Richard; LOW, Patrick (ed.). Multilateralizing Regionalism. UK: Cambridge University Press, 2009, p. 221-261.

FINK, Carsten. Preferential Trade Agreements in Services: Friends or Foes of the Multilateral Trading System? SciencesPos, Groupe d'Économie Mondiale Discussion Paper, Dez. 2007. Disponível em: 
po.fr/content/publications/pdf/Fink_PTA_multilateral_trading_system070208.pdf.

FRANCO, Édson. Apresentação, Revista da Associação Brasileira de Mantenedoras de Ensino Superior, v. 22, n. 33, p. 4, Abr. 2004.

GARCIA, Carolina Policarpo. Efeito rede em fusões no ensino superior. Escola de Economia de São Paulo da Fundação Getúlio Vargas (Dissertação de Mestrado). São Paulo, 2014.

GARCÍA-GUADILLA, Carmen. General Agreement on Trade in Services (GATS), and Higher Education in Latin America: Some ideas to contribute to the discussion. Paper prepared for the Convention of Universities Members of Columbus, Paris, Jul. 2002.

Disponível

em:

http://www.carmengarciaguadilla.com/articulos/GATSandHEinLA.pdf

GROSBON, Sophie. Le droit à l'enseignement supérieur et la liberalisation international du commerce des services. Bruxelles: Bruylant, 2010.

GOMES, Alfredo M.; MORAES, Karine Numes de. Educação superior no Brasil contemporâneo: transição para um sistema de massa, Educação \& Sociedade, v.33, n.118, p. 171-190, 2012.

GOMES, Alfredo M.; ROBERTSON, Susan L.; DALE, Roger. The social condition of higher education: globalisation and (beyond) regionalisation in Latin America, Globalisation, Societies and Education, v.10, n.2, p.221-245, 2012.

HALVORSEN, Kate. Notes on the Realization of the Human Right to education, Human Rights Quarterly, vol. 12, n. 3, pp. 341-364, 1990.

HOEKMAN, Bernard. Assessing the General Agreement on Trade in Services. In: MARTIN, Will and WINTERS, Alan L (edit.). The Uruguay Round and the developing countries. Cambridge: University Press, 1996, p. 88-124.

HOEKMAN, Bernard; MATTOO, Aaditya. Services Trade Liberalization and Regulatory Reform: Re-invigorating International Cooperation. The World Bank Policy Research Working Paper 5517, Jan. 2011. Disponível em: http://elibrary.worldbank.org/content/workingpaper/10.1596/1813-9450-5517.

HORN, Henrik; MAVROIDIS, Petros; SAPIR, André. Beyond the WTO? An Anatomy of EU and US Preferential Trade Agreements, The World Economy, v. 33, n. 11, p. 1565-1588, 2010.

HOUDE, Marie-France; KOLSE-PATIL, Akshay; MIROUDOT, Sébastien. The Interaction between Investment and Services Chapters in Selected Regional Trade Agreements. OECD Trade Policy Working Paper No. 55. Paris: OECD Publication, 2007.

HOWSE, Robert; MUTUA, Makau. Protecting Human Rights in a Global Economy: Challenges for the WTO. International Centre for Human Rights and Democratic Development, 2000.

Disponível em: 
http://www.ichrdd.ca/english/commdoc/publications/globalization/wtoRightsGlob.ht $\underline{\mathrm{ml}}$.

HOWSE, Robert. Human Rights in the WTO: Whose Rights, What Humanity, Comment on Petersmann, European Journal of International Law, v.13, n.3, p. 651659, 2002.

JARA, Alejandro, DOMÍNGUEZ, M. del Carmen. Liberalization of Trade in Services and Trade Negotiations, Journal of World Trade, v. 40, n. 1, pp. 113-127, 2006.

Joint Declaration on Higher Education and the General Agreement on Trade in Services, 28 Set. 2001. Disponível em: http://www.iauhesd.net/sites/default/files/documents/2001_-

joint_declaration_on_higher_education_and the_general_agreement_on_trade_in_s ervices_en.pdf.

KAPUR, Devesh; MEHTA, Pratap Bhanu. Indian Higher Education Reform: From Half-Baked Socialism to Half-Baked Capitalism. Center for International Development at Harvard University Working Paper n. 108, September 2004.

KEMP, Steven. Trade in education services and the impacts of barriers to trade. In: FINDLAY, Christopher; WARREN, Tony (eds.). Impediments to Trade in Services: Measurement and Policy Implications. New York: Routledge, 2000, p. 247-261.

KENNEDY, David. Challenging Expert Rule: The Politics of Global Governance, Sidney Law Review, v.27, p. 1-24, 2005.

KENNEDY, David. Law and the Political Economy of the World, Leiden Journal of International Law, v.26, p. 7-48, 2013.

KENNEDY, David. The Politics of the Invisible College: International Governance and the Politics of Expertise, European Human Rights Law Review, n.5, p. 463-498, 2001.

KNIGHT, Jane. Trade in Higher Education Services: The Implications of GATS. Report for the observatory on borderless higher education, Mar. 2002.

KRAFFT, Mathias-Charles. Les effets et la portée des engagements pris par la Suisse dans la cadre du GATS sur le système de l'éducation suisse. In: OFES, Office federal de l'éducation et de la science. Les effets de l'AGCS sur le système éducatif suisse. Berne, 2003, p. 7-60.

KROTON. Comunicado Kroton - Fato Relevante, 22 Abr. 2013. Disponível em: http://ri.kroton.com.br//kroton2010/web/conteudo_pt.asp?tipo=32853\&idioma=0\&co $\underline{\text { nta }=28}$. Acesso em 28 Abr. 2013.

LANG, Andrew. Rethinking Trade and Human Rights. bepress Legal Series, Working Paper 1685, September 2006. Disponível em: http://law.bepress.com/expresso/eps/1685. 
LANG, Andrew. World Trade Law after neoliberalism: re-imagining the global economic order. New York, Oxford University Press, 2011.

LARSEN, Kurt; VINCENT-LANCRIN, Stéphan. International Trade in Educational Services: Good or Bad? Higher Education Management and Policy, v. 14, n. 3, p. 945, 2002.

LEVY, Daniel C. Unanticipated Development: Perspectives on Private Higher Education's Emerging Roles, PROPHE Working Paper Series, n.1, Abr. 2002. Disponível em: http://www.albany.edu/dept/eaps/prophe/publication/paper/PROPHEWP01_files/PR OPHEWP01.pdf.

LIM, Aik Hoe; SANER, Raymond. Rethinking Trade in Education Services: A Wake-Up Call for Trade Negotiators, Journal of World Trade, v. 45, n. 5, 993-1036, 2011.

MANZINI, Eduardo José. Uso da Entrevista em Dissertações e Teses produzidas em um Programa de Pós-graduação em Educação, Revista Percurso - NEMO, v. 4, n. 2, p. 149-171, 2012.

MARCHETTI, Juan A. Developing Countries in the WTO Services Negotiations. Staff Working Paper ERSD-2004-06, Set. 2004.

MARGINSON, Simon. Markets in education. St. Leonards, N.S.W.: Allen \& Unwin, 1997.

MARGINSON, Simon. Dynamics of national and global competition in higher education. Higher Education, v. 52, p. 1-39, 2006.

MATOO, Aaditya; SAUVÉ, Pierre. Services. In: CHAUFFOUR, Jean-Pierre; MAUR, Jean-Christophe (ed.). Preferential Trade Agreement Policies for Development: A Handbook. Washington: The World Bank, 2011, p. 235-274.

McDOWAN, Tristan. O crescimento da educação superior privada no Brasil: implicações para as questões de equidade, qualidade e benefício público, Archivos Analíticos de Políticas Educativas, v.13, n.27, p. 1-20, Abr. 2005.

McDOWAN, Tristan. Is There A Universal Right To Higher Education? British Journal of Educational Studies, v.60, n.2, p.111-128, 2012.

McMURTRY, John. Education and the market model. Journal of Philosophy of Education, v. 25, n. 2, p. 209-218, 1991.

McQUEEN, Matthew. The EU's Free-trade Agreements with Developing Countries: A Case of Wishiful Thinking? The World Economy, v. 25, n. 9, p. 1369-1385, 2002.

MIROUDOT, Sebástien. Investment. In: CHAUFFOUR, Jean-Pierre; MAUR, JeanChristophe. Preferential Trade Agreement Policies for Development: A Handbook. Washington: Banco Mundial, 2011, p. 307-326. 
MONTEIRO, Agostinho Reis. Droit international de l'éducation: une discipline nouvelle, International Review of Education, v. 54, pp. 193-210, 2008.

NAG, Biswajit; CHAISSE, Julien; CHAKRABORTY, Debashis. Mapping the Universe of Services Disciplines in PTAs: The Indian Contribution. Pacific Economic Cooperation Council and the Asian Development Bank Institute Inaugural Conference: Strategies to enhance Competitiveness and Facilitate Regional Trade and Investment in Services. Disponível em: http://www.pecc.org/resources/doc_view/1704-mapping-the-universe-of-servicesdisciplines-in-ptas-the-indian-contribution-paper.

NINA, Alexandre Mendes. Situação geral das negociações de serviço no âmbito do GATS, Revista da Associação Brasileira de Mantenedoras de Ensino Superior, v. 22, n. 33, p. 36-43, Abr. 2004.

OLIVEIRA, Romualdo Portela de. Reformas educativas no Brasil na década de 90. In: CATANI, Afrânio Mendes; OLIVEIRA, Romualdo Portela de. Reformas educacionais em Portugal e no Brasil. Belo Horizonte: Autêntica, 2000, p. 77-94.

OLIVERIO, Cecília Kaneto. O direito ao desenvolvimento e o comércio internacional de serviços educacionais. Faculdade de Direito da Universidade de São Paulo (Dissertação de Mestrado). São Paulo, 2009.

ORGANIZAÇÃO DAS NAÇÕES UNIDAS PARA A EDUCAÇÃO, A CIÊNCIA E A CULTURA. Higher Education in a Globalized Society. UNESCO Education Position Paper, 2004.

ORGANIZAÇÃO DAS NAÇÕES UNIDAS PARA A EDUCAÇÃO, A CIÊNCIA E A CULTURA. Recomendação relativa à condição do pessoal docente do ensino superior, Nov. $1997 . \quad$ Disponível em: www.cpihts.com/PDF02/Recomendacao\%20UNESCO.pdf.

ORGANIZAÇÃO DAS NAÇÕES UNIDAS PARA A EDUCAÇÃO, A CIÊNCIA E A CULTURA. Convenção relativa à Luta contra a Discriminação no campo do Ensino. Disponível em: http://portal.mj.gov.br/sedh/ct/legis_intern/conv_discriminacao_ensino.htm.

ORGANIZAÇÃO DAS NAÇÕES UNIDAS. Conselho Econômico e Social. Liberalization of trade in services and human rights. Report of the High Commissioner on Human Rights (E/CN.4/Sub.2/2002/9), 2002. Disponível em: www.ohchr.org/EN/Issues/Globalization/Pages/ReportsHC.aspx.

ORGANIZAÇÃO DAS NAÇÕES UNIDAS. Declaração Universal dos Direitos Humanos. Disponível em: http://portal.mj.gov.br/sedh/ct/legis_intern/ddh_bib_inter_universal.htm.

ORGANIZAÇÃO DAS NAÇÕES UNIDAS. Pacto Internacional sobre Direitos Econômicos, Sociais e Culturais. Disponível em: http://portal.mj.gov.br/sedh/ct/legis_intern/pacto_dir_economicos.htm. 
ORGANIZAÇÃO MUNDIAL DO COMÉRCIO. Acordo Constitutivo da Organização Mundial do Comércio. Marraqueche, 15 abr. 1994. Decreto n. ${ }^{\circ}$ 1.355/94, publicado no D.O.U. de 31/12/94. Disponível em: 〈www.planalto.gov.br〉.

ORGANIZAÇÃO MUNDIAL DO COMÉRCIO. Acordo Geral sobre o Comércio de Serviços (GATS). Marraqueche, 15 abr. 1994. Decreto n. ${ }^{\circ} 1.355 / 94$ publicado no D.O.U. de 31/12/94. Disponível em: <www.planalto.gov.br>.

ORGANIZAÇÃO MUNDIAL DO COMÉRCIO. Conselho sobre Comércio de Serviços. Education services: background Note by the Secretariat. 23 de setembro de 1998 (S/CSS/W/59). Disponível em: <www.docsonline.wto.org>.

ORGANIZAÇÃO MUNDIAL DO COMÉRCIO. Services sectoral classification list, 10 Jul. 1991 (MTN.GNS/W/120). Disponível em: 〈www.docsonline.wto.org〉.

ORGANIZAÇÃO MUNDIAL DO COMÉRCIO. World Trade Report 2011. The WTO and preferential trade agreements: From co-existence to coherence. Disponível em: <www.wto.org/english/res_e/publications_e/wtr11_e.htm>.

ORGANIZAÇÃO PARA COOPERAÇÃO E DESENVOLVIMENTO ECONÔMICO. Investment for Development: Investment Policy Co-operation with Non-OECD Economies. Annual Report 2006. Paris: OECD Publications, 2006.

ORTINO, Federico. Services. In: LESTER, Simon; MERCURIO, Bryan. Bilateral and Regional Trade Agreements: Commentary and Analysis (ed.). New York: Cambridge University Press, 2009, p. 184-214.

PANAGARIYA, Avind. EU Preferential Trade Policies and Developing Countries. The World Economy, v. 25, n. 10, p. 1415-1432, 2002.

PETERSMANN, Ernst-Ulrich. Human Rights, Markets and Economic Welfare: Constitutional Functions of the Emerging UN Human Rights Constitution. In: ABBOTT, Frederick M.; BREINING-KAUFMANN, Christine; COTTIER, Thomas (edit.). International Trade and Human Rights: Foundations and Conceptual Issues. University of Michigan, 2006, p. 29-68.

PETERSMANN, Ernst-Ulrich. Time for a United Nations 'Global Compact' for Integrating Human Rights into the Law of Worldwide Organizations: Lessons from European Integration, European Journal of International Law, v. 13, n. 3, p. 621-650, 2002.

Porto Alegre Declaration, 27 Abr. 2002. Disponível em: www.gatswatch.org/educationoutofgats/PortoAlegre.doc.

POUPART, Jean. A entrevista de tipo qualitativa: considerações epistemológicas, teóricas e metodológicas. In: POUPART, Jean; DESLAURIERS, Jean-Pierre; GROULX, Lionel-H; LAPERRIÈRE, Anne; MAYER, Robert; PIRES, Álvaro. A pesquisa qualitativa: enfoques epistemológicos e metodológicos. Tradução de Ana Cristina Arantes Nasser. Petrópolis, RJ: Vozes, 2012, p. 215-253. 
PUSSER, Brian; WOLCOTT, David A. A Crowded Lobby: Nonprofit and For-Profit Universities and the Emerging Politics of Higher Education. In: BRENEMAN, David W.; PUSSER, Brian; TURNER, Sarah E. (edit.). Earnings from Learning: The Rise of For-Profit Universities. Albany: State University of New York Press, 2006, p. 167194.

PUSSER, Brian. Higher Education, Markets, and the Preservation of the Public Good. In: BRENEMAN, David W.; PUSSER, Brian; TURNER, Sarah E. (edit.). Earnings from Learning: The Rise of For-Profit Universities. Albany: State University of New York Press, 2006, p. 23-49.

PUSSER, Brian. Reconsidering Higher Education and the Public Good: The Role of Public Spheres. In: TIERNEY, William G. (edit.). Governance and the Public Good. Albany: State University of New York Press, 2006, p. 11-27.

RAYCHAUDHURI, Ajitava; DE, Prabir. Barriers to Trade in Higher Education Services - Empirical Evidence from Asia-Pacific Countries. Asia-Pacific Trade and Investiment Review, v. 3, n. 2, p. 67-88, Dez. 2007.

ROBERTSON, Susan; BONAL, Xavier; DALE, Roger. GATS and the Education Service Industry: The Politics of Scale and Global Reterritorialization, Comparative Education Review, v. 46, n. 4, p. 472-495, 2002.

ROY, Martin; MARCHETTI, Juan; LIM, Hoe. Services liberalization in the new generation of preferential trade agreements: how much further than the GATS? In: ESTEVADEORDAL, Antoni; SUOMINEN, Kati; TEH, Robert (ed.). Regional Rules in the Global Trading System. UK: Cambridge University Press, 2009, p. 316-364.

SAMPAIO, Helena. Ensino superior privado: reprodução e inovação no padrão de crescimento, Revista da Associação Brasileira de Mantenedoras de Ensino Superior, v.27, n.39, p.45-58, Dez. 2009.

SAMPAIO, Helena. O Setor Privado de Ensino Superior no Brasil: Continuidades e Transformações. Revista Ensino Superior Unicamp, n. 4, p. 28-43, Out. 2011.

SCHEFER, Krista Nadakavukaren. The Use of Trade Instruments in the Pursuit of Human Rights: European Foreign Policy. In: ABBOTT, Frederick, BREININGKAUFMANN, Christine, COTTIER, Thomas (edit.). International Trade and Human Rights: Foundations and Conceptual Issues. The University of Michigan Press, 2006, p. 305-319.

SCHOTT, Jeffrey J.; LEE, Minsoo; MUIR, Julia. Prospects for Services Trade Negotiations. Asian Development Bank Economics Working Paper Series \#319, Nov. 2012. Disponível em: http://papers.ssrn.com/sol3/papers.cfm?abstract_id=2174129.

SÉCCA, Rodrigo Ximenes; LEAL, Rodrigo Mendes. Análise do setor de ensino superior privado no Brasil. BNDES Setorial, n. 30, p. 103-156, Set. 2009. 
SGUISSARDI, Valdemar. Diferenciação e diversificação: marcas das políticas de educação superior no final do século. In: SGUISSARDI, Valdemar (org.). Educação superior: velhos e novos desafios. São Paulo: Xamã, 2000, p. 47-62.

SGUISSARDI, Valdemar. O desafio da educação superior no Brasil: quais são as perspectivas. In: SGUISSARDI, Valdemar (org.). Educação superior: velhos e novos desafios. São Paulo: Xamã, 2000, p. 9-46.

SILVA JR, João dos Reis; SGUISSARDI, Valdemar. A educação superior privada no Brasil: novos traços de identidade. In: SGUISSARDI, Valdemar (org.). Educação superior: velhos e novos desafios. São Paulo: Xamã, 2000, p. 155-177.

SINCLAIR, Scott. GATS: How the World Trade Organization's new 'services' negotiations threaten democracy, Canadian Centre for Policy Alternatives, September 2000 .

SINGH, Kishore. Right to Education International Legal Obligations, International Journal of Educational Law and Policy, v. 103, n. 1, pp. 103-118, 2005.

SOUZA, Igor Abdalla Medina de. O liberalismo interdisciplinar DI/RI no pós-Guerra Fria: Uma análise crítica. Revista Ética e Filosofia Política, n. 13, v. 2, p. 25-44, Jun. 2011.

TASQUETTO, Lucas da Silva; RORIZ, João Henrique Ribeiro. Comércio e Regras sobre Propriedade Intelectual nos Acordos Preferenciais de Comércio. In: OLIVEIRA, Ivan Tiago Machado; BADIN, Michelle Ratton Sanchez. Tendências Regulatórias nos Acordos Preferenciais de Comércio no Século XXI: os casos de Estados Unidos, União Europeia, China e Índia. Brasília: IPEA, 2013, p. 145-167.

THAM, Siew Yean. Trade in Higher Education Services in Malaysia: Key Policy Challenges. Higher Education Policy, v. 23, 2010, p. 99-122.

TOH, Mun-Heng. Internationalization of Tertiary Education Services in Singapore. Asian Development Bank Institute Working Papers Series No 388, Out. 2012. Disponível em: http://papers.ssrn.com/sol3/papers.cfm?abstract_id=2161691.

TRAPERO-BALLESTERO, Angel. Le Droit à l'Éducation et le Droit International. In: DUPUY, René Jean. L'Avenir Du Droit International Dans Un Monde Multiculturel. La Haye: Martinus Nijhoff Publishers, 1984, p. 391-400.

TRINDADE, Hélgio. O ensino superior na América Latina: um olhar longitudinal e comparativo. In: TRINDADE, Hélgio; BLANQUER, Jean-Michel. Os desafios da educação na América Latina. Petrópolis: Editora Vozes, 2002, p. 15-31.

TRIVIÑOS, Augusto N. S. Introdução à pesquisa em ciências sociais: a pesquisa qualitativa em educação. São Paulo: Editora Atlas, 1987

VALE, Andréa Araujo do. A expansão do segmento privado-mercantil na educação superior brasileira - o caso da Estácio de Sá. In: 35ª Reunião Anual da Associação Nacional de Pós-Graduação e Pesquisa em Educação, 2012, Porto de Galinhas. 
Educação, Cultura, Pesquisa e Projetos de Desenvolvimento: o Brasil do século XXI. Rio de Janeiro: ANPED, 2012.

VANDUZER, J. Anthony. Navigating between the Poles: Unpacking the Debate on the Implications for Development of GATS Obligations Relating to Health and Education Services. In: PETERSMANN, Ernst-Ulrich (edit.). Reforming the World Trading System: Legitimacy, Efficiency and Democratic Governance. Oxford: Oxford University Press, 2005, p. 167-204.

VERGER, Antoni; BONAL, Xavier. Against GATS: the Sense of a Global Struggle, Journal for Critical Educational Policy Studies, v.4, n.1, p.1-18, 2006.

VERGER, Antoni; NOVELLI, Mario; ALTINYELKEN, Hülya Kosar. Global Education Policy and International Development: An Introductory Framework. In: VERGER, Antoni; NOVELLI, Mario; ALTINYELKEN, Hülya Kosar (edit.). Global Education Policy and International Development: New Agendas, Issues and Policies. London and New York: Bloomsbury, 2012, p. 3-31.

VERGER, Antoni; PAASSEN, Barbara van. Human development vis-à-vis free trade: Understanding developing countries' positions in trade negotiations on education and intellectual property rights, Review of International Political Economy, iFirst, p.1-28, 2012.

VERGER, Antoni. Making sense of the GATS debate: semiotic analysis of the conflicting ideas on the education/free-trade relationship, International Studies in Sociology of Education, v.21, n.3, p. 231-254, 2010.

VERGER, Antoni. Measuring educational liberalisation. A global analysis of GATS, Globalisation, Societies and Education, v.6, n.1, p.13-31, 2009b.

VERGER, Antoni. The constitution of a new global regime: Higher education in the GATS/WTO framework. In: EPSTEIN, Debbie; BODEN, Rebecca; DEEM, Rosemary; RIZVI, Fazal; WRIGHT, Susan (edit.). World Yearbook of Education 2008 - Geographies of Knowledge, Geometries of Power: Framing the Future of Higher Education. New York: Routledge, 2007, p. 111-127.

VERGER, Antoni. The Merchants of Education: Global Politics and the Uneven Education Liberalization Process within the WTO, 2009. Disponível em: http://educationanddevelopment.files.wordpress.com/2008/04/verger_gats-cer.pdf.

VLK, Ales. Higher Education and GATS: Regulatory Consequences and Stakeholders' Responses. Tese (Doutorado em Educação). Universidade de Twente (Universiteit Twente), 2006.

WOOLCOCK, Stephen. European Union Policy Towards Free Trade Agreements. ECIPE Working Paper, n. 3, 2007. Disponível em: http://www.ecipe.org/publications/ecipe-working-papers/european-union-policytowards-free-trade-agreements. 


\section{Entrevistas}

ENTREVISTADO 01 (Pró-Reitor da Instituição A adquirida por grupo estrangeiro). Entrevistador: Lucas da Silva Tasquetto, 13 Dez. 2012.

ENTREVISTADO 02 (Diretor de Curso do grupo nacional A). Entrevistador: Lucas da Silva Tasquetto, 26 Fev. 2013.

ENTREVISTADO 03 (Professor da Instituição B adquirida por grupo estrangeiro). Entrevistador: Lucas da Silva Tasquetto, 26 Fev. 2013.

ENTREVISTADO 04 (Coordenador de Curso da Instituição $C$ adquirida por grupo estrangeiro). Entrevistador: Lucas da Silva Tasquetto, 27 Fev. 2013.

ENTREVISTADO 05 (Professor da Instituição D adquirida por grupo estrangeiro). Entrevistador: Lucas da Silva Tasquetto, 01 Mar. 2013.

ENTREVISTADO 06 (Professor da Instituição D adquirida por grupo estrangeiro). Entrevistador: Lucas da Silva Tasquetto, 13 Mar. 2013.

ENTREVISTADO 07 (Professor da Instituição D adquirida por grupo estrangeiro). Entrevistador: Lucas da Silva Tasquetto, 14 Mar. 2013.

ENTREVISTADO 08 (Gestor da Instituição E adquirida por grupo nacional). Entrevistador: Lucas da Silva Tasquetto, 15 Mar. 2013.

ENTREVISTADO 09 (Consultor do setor privado educacional). Entrevistador: Lucas da Silva Tasquetto, 01 Abr. 2013.

ENTREVISTADO 10 (Consultor do setor privado educacional). Entrevistador: Lucas da Silva Tasquetto, 10 Dez. 2013.

RODRIGUES, Gabriel Mário (Presidente da Associação Brasileira de Mantenedoras de Ensino Superior). Entrevistador: Lucas da Silva Tasquetto, 18 Mar. 2013.

VALENTE, Ivan (Deputado Federal - PSOL/SP). Entrevistador: Lucas da Silva Tasquetto, 14. Mai. 2014.

\section{Legislação}

BRASIL. Decreto $\mathrm{n}^{\circ}$ 5.773, de 09 de maio de 2006. Disponível em: www.planalto.gov.br/ccivil_03/_Ato2004-2006/2006/Decreto/D5773.htm. Acesso em 17 Nov. 2013. 
BRASIL. Lei no 9.131, de 24 de novembro de 1995. Disponível em: Disponível em: www.planalto.gov.br/ccivil_03/Leis/L9131.htm. Acesso em 19 Abr. 2013.

BRASIL. Lei $\mathrm{n}^{\circ}$ 9.394, de 20 de dezembro de 1996. Estabelece as diretrizes e bases da educação nacional. Disponível em: www.planalto.gov.br/ccivil_03/Leis/L9394.htm. Acesso em 15 Nov. 2013.

BRASIL. Lei $\mathrm{n}^{\circ}$ 10.861, de 14 de abril de 2004. Disponível em: www.planalto.gov.br/ccivil_03/_ato2004-2006/2004/Lei/L10.861.htm. Acesso em: 12 Nov. 2013.

BRASIL. Portaria Normativa MEC n ${ }^{\circ}$ 40, de 12 dezembro de 2007. Disponível em: http://meclegis.mec.gov.br/documento/view/id/17. Acesso em: 10 Nov. 2013.

\section{Matérias de Jornais e Revistas}

As empresas de educação na bolsa diante de um ciclo virtuoso. Valor Econômico, 19 Out. 2010. Disponível em: http://www.valor.com.br/arquivo/852691/empresas-deeducacao-na-bolsa-diante-de-um-ciclo-virtuoso. Acesso em 02 Jan. 2011.

BRAGA, Ryon. Negócios no setor de educação privada, 24 Jan. 2011. Disponível em: http://www.hoper.com.br/artigo-hoper.php?id=43. Acesso em 31 Jan. 2013.

Education shouldn't be a profit earning business: Chidambaram. The Indian Express, 17 Jan. 2010. Disponível em: http://archive.indianexpress.com/news/educationshouldnt-be-a-profit-earning-business-chidambaram/568290/.

JAPPE, Lívia. Brasil rejeita, na OMC, proposta de abertura do setor de educação. Ministério da Educação, 17 Mai. 2006. Disponível em: http://portal.mec.gov.br/index.php?option=com_content $\&$ view $=$ article\&id=6258\&cati $\underline{\mathrm{d}=221 \& \text { Itemid }=86 .}$.

JULIBONI, Márcio. R\$ 367 mi: o cacife da Anima Educação para ir às compras. Exame.com, 28 Out. 2013.2 Disponível em: http://exame.abril.com.br/negocios/aquisicoes-fusoes/noticias/r-367-mi-o-cacife-daanima-educacao-para-ir-as-compras.

KOIKE, Beth. Anhanguera demite 1,5 mil professores, segundo Fepesp. Valor Econômico, 06 Fev. 2012. Disponível em: http://www.valor.com.br/empresas/2519622/anhanguera-demite-15-mil-professoressegundo-fepesp. Acesso em 12 Out. 2012.

LORENZONI, Ionice. MEC não quer o ingresso da educação na OMC. Ministério da Educação, $07 \quad$ Jun. $2005 \quad$ Disponível em: http://portal.mec.gov.br/index.php?option=com_content\&view=article\&id=3219\&cati $\underline{\mathrm{d}=221}$. 
Ministro rejeita projeto que dispensa mestrado a professor universitário. Portal MEC, 13 Jul. 2011. Disponível em: http://portal.mec.gov.br/index.php?option=com_content\&view=article\&id=16871.

Acesso em 13 Jul. 2011

OLIVON, Beatriz. Ser Educacional estreia na Bovespa com valorização. Exame.com, 29 Out. 2013. Disponível em: http://exame.abril.com.br/mercados/noticias/sereducacional-estreia-na-bovespa-com-valorizacao. Acesso em 30 Out. 2013.

OSCAR, Naiana. Educação que dá dinheiro. O Estado de São Paulo, 11 Jun. 2012. Disponível em: http://economia.estadao.com.br/noticias/geral,educacao-que-dadinheiro-imp-,884821. Acesso em 11 Jun. 2012.

OSCAR, Naiana. Grupo Anima compra Universidade São Judas Tadeu por R \$ 320 milhões. $O$ Estado de São Paulo, 10. Abr. 2014. Disponível em: http://economia.estadao.com.br/noticias/economia-geral,grupo-anima-comprauniversidade-sao-judas-tadeu-por-r-320-milhoes, 181757,0.htm. Acesso em 10 Abr. 2014.

PIMENTEL, Gabriela. Audiência pública debate demissões no Grupo Educacional Anhanguera. TV Assembleia - Assembleia Legislativa do Estado do Rio Grande do Sul, $24 \quad$ Abr. 2012. 24 Disponível http://www2.al.rs.gov.br/mikibreier/Imprensa/TVAssembleia/tabid/4904/IdOrigem/1/ Id_Cadastro_Video/5157/Default.aspx. Acesso em 12 Out. 2012.

Profiteering in education by private sector will not be allowed: Sibal. The Hindu, 10 Fev. 2010. Disponível em: http://www.thehindu.com/news/national/profiteering-ineducation-by-private-sector-will-not-be-allowed-sibal/article104274.ece.

Retrocesso no ensino superior. O Estado de São Paulo, 12 Jul. 2011. Disponível em: http://www.estadao.com.br/noticias/impresso,retrocesso-no-ensinosuperior,743708,0.htm. Acesso em 13 Jul. 2011.

ROY, Shreya; GHOSH, Deboljyoti. Pvt colleges defend capitation fee. The Financial Express, 22 Mar. 2010. Disponível em: http://www.financialexpress.com/news/pvtcolleges-defend-capitation-fee/593749/0. Acesso em 23 Out. 2013.

TREVISANI, Paulo. Universidades privadas se multiplican en Brasil. The Wall Street Journal, 26 Jun. 2011.2 Disponível em: http://online.wsj.com/news/articles/SB10001424052702304447804576410414208690 234?tesla=y\&tesla=y. Acesso em 27 Jun. 2011.

\section{Palestras}

ALCALAY, Eduardo. Palestra, 08 Nov. 2011. Seminário ABMES: Lucro e qualidade acadêmica são compatíveis na Educação Superior? Disponível em: http://www.abmes.org.br/abmes/video/detalhe/id/42. Acesso em 24 Fev. 2013. 
CAPELATO, Rodrigo. Palestra, 10 Out. 2013. Comissão de Educação da Câmara dos Deputados. A Fusão entre as Empresas Kroton Educacional do Grupo Pitágoras, e Anhanguera Educacional, e seu impacto na qualidade do Ensino Brasileiro. Disponível em: http://www2.camara.leg.br/atividadelegislativa/comissoes/comissoespermanentes/cec/reunioes/videoArquivo? codSessao=46059\&codReuniao=33860.

CARBONARI NETTO, Antônio. Palestra, 08 Nov. 2011. Seminário ABMES: Lucro e qualidade acadêmica são compatíveis na Educação Superior? Disponível em: http://www.abmes.org.br/abmes/video/detalhe/id/39. Acesso em 25 Fev. 2013.

CARVAlHO, Cristina Helena Almeida de. Palestra, 10 Out. 2013. Comissão de Educação da Câmara dos Deputados. A Fusão entre as Empresas Kroton Educacional do Grupo Pitágoras, e Anhanguera Educacional, e seu impacto na qualidade do Ensino Brasileiro. Disponível em: http://www2.camara.leg.br/atividadelegislativa/comissoes/comissoes-

permanentes/cec/reunioes/videoArquivo?codSessao=46059\&codReuniao=33860.

\section{Projetos de Lei}

BRASIL. Projeto de Lei n 2138, de 2003, pelo Deputado Ivan Valente (PSOL/SP). Disponível http://www.camara.gov.br/proposicoesWeb/prop_mostrarintegra?codteor=168570\&fil ename=Tramitacao-PL+2138/2003.

BRASIL. Projeto de Lei n ${ }^{\circ}$ 6358, de 2009, pelo Deputado Wilson Picler (PDT/PR). Disponível em: http://www.camara.gov.br/proposicoesWeb/prop_mostrarintegra?codteor=710779\&fil ename $=$ PL+6358/2009.

BRASIL. Projeto de Lei $n^{\circ}$ 7040, de 2010, pela Deputada Alice Portugal (PCdoB/BA). Disponível em: http://www.camara.gov.br/proposicoesWeb/prop_mostrarintegra?codteor=748162\&fil ename $=P L+7040 / 2010$.

Parecer do Relator $n^{\circ} 1$ CEC, 25 de abril de 2012, pelo Deputado Paulo Rubem Santiago (PDT/PE). Disponível em: http://www.camara.gov.br/proposicoesWeb/prop_mostrarintegra?codteor=985515\&fil ename=Tramitacao-PL+2138/2003.

Voto em Separado no 1 CEC, 23 de maior de 2012, pelo Deputado Izalci (PR/DF). Disponível em: http://www.camara.gov.br/proposicoesWeb/prop_mostrarintegra?codteor=994447\&fil ename $=$ Tramitacao-PL+2138/2003. 
Sites Consultados

www.abmes.org.br

www.anhanguera.com

$\underline{\text { www.camara.gov.br }}$

$\underline{\text { www.cmconsultoria.com.br }}$

www.hoper.com.br

www.ri.animaeducacao.com.br

$\underline{\text { www.ri.kroton.com.br }}$

www.ri.sereducacional.com 


\section{ANEXOS}

Tabela 19 - Entrevistas

\begin{tabular}{|c|c|c|c|c|}
\hline Nome & Instituição/Associação & Posição & Data & Formato \\
\hline Entrevistado 01 & $\begin{array}{l}\text { Instituição A comprada por } \\
\text { grupo estrangeiro }\end{array}$ & Pró-Reitor & 13.12 .2012 & Presencial \\
\hline Entrevistado 02 & Grupo nacional A & Diretor de Curso & 26.02 .2013 & Presencial \\
\hline Entrevistado 03 & $\begin{array}{l}\text { Instituição B comprada por } \\
\text { grupo estrangeiro }\end{array}$ & Professor & 26.02 .2013 & Presencial \\
\hline Entrevistado 04 & $\begin{array}{l}\text { Instituição C comprada por } \\
\text { grupo estrangeiro }\end{array}$ & Coordenador de Curso & 27.02 .2013 & Presencial \\
\hline Entrevistado 05 & $\begin{array}{l}\text { Instituição D comprada por } \\
\text { grupo estrangeiro }\end{array}$ & Professor & 01.03 .2013 & Presencial \\
\hline Entrevistado 06 & $\begin{array}{l}\text { Instituição D comprada por } \\
\text { grupo estrangeiro }\end{array}$ & Professor & 13.03.2013 & Presencial \\
\hline Entrevistado 07 & $\begin{array}{l}\text { Instituição D comprada por } \\
\text { grupo estrangeiro }\end{array}$ & Professor & 14.03 .2013 & Presencial \\
\hline Entrevistado 08 & $\begin{array}{l}\text { Instituição E comprada por } \\
\text { grupo nacional }\end{array}$ & Gestor & 15.03 .2013 & Presencial \\
\hline Gabriel Mário Rodrigues & Anhembi-Morumbi e ABMES & Reitor / Presidente da ABMES & 18.03 .2013 & E-mail \\
\hline Entrevistado 09 & & Consultor do setor privado & 01.04 .2013 & E-mail \\
\hline
\end{tabular}




\begin{tabular}{|l|l|l|l|l|}
\hline Entrevistado 10 & Consultor do setor privado & 10.12 .2013 & E-mail \\
\hline Ivan Valente & & Deputado Federal & 14.05 .2014 & E-mail \\
\hline
\end{tabular}


Tabela 20 - Evolução do número de matrículas de graduação no Brasil ${ }^{499}$

\begin{tabular}{|c|c|c|c|c|c|c|c|c|c|}
\hline \multirow{2}{*}{ Ano } & \multicolumn{3}{|c|}{ TOTAL } & \multicolumn{3}{c|}{ PRESENCIAL } & \multicolumn{3}{c|}{ EAD } \\
\cline { 2 - 10 } & Total & Pública & Privada & Total & Pública & Privada & Total & Pública & Privada \\
\hline $\mathbf{2 0 0 2}$ & 3.520 .627 & 1.085 .977 & 2.434 .650 & 3.479 .913 & 1.051 .655 & 2.428 .258 & 40.714 & 34.322 & 6.392 \\
\hline $\mathbf{2 0 0 3}$ & 3.936 .933 & 1.176 .174 & 2.760 .759 & 3.887 .022 & 1.136 .370 & 2.750 .652 & 49.911 & 39.804 & 10.107 \\
\hline $\mathbf{2 0 0 4}$ & 4.223 .344 & 1.214 .317 & 3.009 .027 & 4.163 .733 & 1.178 .328 & 2.985 .405 & 59.611 & 35.989 & 23.622 \\
\hline $\mathbf{2 0 0 5}$ & 4.567 .798 & 1.246 .704 & 3.321 .094 & 4.453 .156 & 1.192 .189 & 3.260 .967 & 114.642 & 54.515 & 60.127 \\
\hline $\mathbf{2 0 0 6}$ & 4.883 .852 & 1.251 .365 & 3.632 .487 & 4.676 .646 & 1.209 .304 & 3.467 .342 & 207.206 & 42.061 & 165.145 \\
\hline $\mathbf{2 0 0 7}$ & 5.250 .147 & 1.335 .177 & 3.914 .970 & 4.880 .381 & 1.240 .968 & 3.639 .413 & 369.766 & 94.209 & 275.557 \\
\hline $\mathbf{2 0 0 8}$ & 5.808 .017 & 1.552 .953 & 4.255 .064 & 5.080 .056 & 1.273 .965 & 3.806 .091 & 727.961 & 278.988 & 448.973 \\
\hline $\mathbf{2 0 0 9}$ & 5.954 .021 & 1.523 .864 & 4.430 .157 & 5.115 .896 & 1.351 .168 & 3.764 .728 & 838.125 & 172.696 & 665.429 \\
\hline $\mathbf{2 0 1 0}$ & 6.379 .299 & 1.643 .298 & 4.736 .001 & 5.449 .120 & 1.461 .696 & 3.987 .424 & 940.179 & 181.602 & 748.577 \\
\hline $\mathbf{2 0 1 1}$ & 6.739 .689 & 1.773 .315 & 4.966 .374 & 5.746 .762 & 1.595 .391 & 4.151 .371 & 992.927 & 177.924 & 815.003 \\
\hline $\mathbf{2 0 1 2}$ & 7.037 .688 & 1.897 .376 & 5.140 .312 & 5.923 .838 & 1.715 .752 & 4.208 .086 & 1.113 .850 & 181.624 & 932.226 \\
\hline
\end{tabular}

Elaborado pelo autor a partir dos dados do Censo da Educação Superior de 2012 (MEC/INEP)

\footnotetext{
${ }^{499}$ Para todos os graus acadêmicos - bacharelado, licenciatura, tecnológico, bacharelado e licenciatura, não informado.
} 
Tabela 21 - Instituições de graduação de ensino superior

\begin{tabular}{|c|c|c|c|}
\hline \multirow{2}{*}{ Ano } & \multicolumn{3}{|c|}{ Categoria Administrativa } \\
\cline { 2 - 4 } & Total & Pública & Privada \\
\hline $\mathbf{2 0 1 2}$ & 2.416 & 304 & 2.112 \\
\hline
\end{tabular}

Elaborado pelo autor a partir dos dados do Censo da Educação Superior de 2012 (MEC/INEP)

Tabela 22 - Cursos de graduação de ensino superior

\begin{tabular}{|c|c|c|c|}
\hline \multirow{2}{*}{ Ano } & \multicolumn{3}{|c|}{ Categoria Administrativa } \\
\cline { 2 - 4 } & Total & Pública & Privada \\
\hline $\mathbf{2 0 1 2}$ & 31.866 & 10.905 & 20.961 \\
\hline
\end{tabular}

Elaborado pelo autor a partir dos dados do Censo da Educação Superior de 2012 (MEC/INEP) 
Tabela 23 - Número de matrículas de graduação presencial por turno segundo a categoria administrativa

\begin{tabular}{|c|c|c|c|}
\hline \multirow{2}{*}{ Ano } & \multirow{2}{*}{$\begin{array}{c}\text { Categoria } \\
\text { Administrativa }\end{array}$} & \multicolumn{2}{|c|}{ Matrículas } \\
\cline { 3 - 4 } & Diurno & Noturno \\
\hline \multirow{2}{*}{$\mathbf{2 0 0 0}$} & Pública & 572.721 & 314.305 \\
\cline { 2 - 4 } & Privada & 611.186 & 1.196 .033 \\
\hline \multirow{2}{*}{$\mathbf{2 0 0 2}$} & Pública & 674.916 & 376.739 \\
\cline { 2 - 4 } & Privada & 801.242 & 1.627 .016 \\
\hline \multirow{2}{*}{$\mathbf{2 0 0 4}$} & Pública & 753.034 & 425.294 \\
\cline { 2 - 4 } & Privada & 956.351 & 2.029 .054 \\
\hline \multirow{2}{*}{$\mathbf{2 0 0 6}$} & Pública & 761.758 & 447.546 \\
\cline { 2 - 4 } & Privada & 1.067 .218 & 2.400 .124 \\
\hline \multirow{2}{*}{$\mathbf{2 0 0 8}$} & Pública & 793.181 & 480.784 \\
\cline { 2 - 4 } & Privada & 1.107 .262 & 2.698 .829 \\
\hline \multirow{2}{*}{$\mathbf{2 0 1 0}$} & Pública & 906.457 & 555.192 \\
\cline { 2 - 4 } & Privada & 1.085 .183 & 2.902 .241 \\
\hline \multirow{2}{*}{$\mathbf{2 0 1 2}$} & Pública & 1.055 .680 & 660.072 \\
\cline { 2 - 4 } & Privada & 1.129 .579 & 3.078 .507 \\
\hline \multirow{2}{*}{} & & & \\
\hline
\end{tabular}

Elaborado pelo autor a partir dos dados do Censo da Educação Superior de 2012 (MEC/INEP) 
Tabela 24 - Transações no setor educacional no Brasil (Pesquisa de Fusões e Aquisições KPMG) $)^{500}$

\begin{tabular}{|c|c|c|c|c|c|c|c|c|c|}
\hline Período & $\mathbf{d}$ & $\mathbf{c b 1}$ & $\mathbf{c b 2}$ & $\mathbf{c b 3}$ & $\mathbf{c b}$ & $\mathbf{c b 5}$ & $\mathbf{c b}$ & Total (d + cb) & $\begin{array}{c}\text { Ranking } \\
\text { setorial de } \\
\text { transaçóes }\end{array}$ \\
\hline $1^{\circ}$ trim. 2008 & 13 & 0 & 0 & 0 & 0 & 0 & 0 & 13 & $3^{\circ}$ \\
\hline $2^{\circ}$ trim. 2008 & 17 & 0 & 0 & 0 & 0 & 0 & 0 & 17 & $3^{\circ}$ \\
\hline $3^{\circ}$ trim. 2008 & 10 & 0 & 1 & 0 & 0 & 0 & 1 & 11 & $4^{\circ}$ \\
\hline $4^{\circ}$ trim. 2008 & 12 & 0 & 0 & 0 & 0 & 0 & 0 & 12 & $1^{\circ}$ \\
\hline $1^{\circ}$ trim. 2009 & 1 & 2 & 0 & 0 & 0 & 0 & 2 & 3 & $10^{\circ}$ \\
\hline $2^{\circ}$ trim. 2009 & 3 & 1 & 0 & 0 & 0 & 0 & 1 & 4 & $5^{\circ}$ \\
\hline $3^{\circ}$ trim. 2009 & 2 & 0 & 0 & 0 & 0 & 0 & 0 & 2 & $14^{\circ}$ \\
\hline $4^{\circ}$ trim. 2009 & 2 & 0 & 0 & 1 & 0 & 0 & 1 & 3 & $14^{\circ}$ \\
\hline $1^{\circ}$ trim. 2010 & 3 & 2 & 0 & 0 & 0 & 0 & 2 & 5 & $10^{\circ}$ \\
\hline $2^{\circ}$ trim. $2010^{501}$ & 1 & 0 & 0 & 0 & 0 & 0 & 0 & 1 & \\
\hline $3^{\circ}$ trim. 2010 & 7 & 2 & 0 & 0 & 0 & 0 & 2 & 9 & $3^{\circ}$ \\
\hline $4^{\circ}$ trim. 2010 & 4 & 1 & 0 & 0 & 0 & 0 & 1 & 5 & $17^{\circ}$ \\
\hline $1^{\circ}$ trim. 2011 & 4 & 1 & 0 & 0 & 0 & 0 & 1 & 5 & $9^{\circ}$ \\
\hline $2^{\circ}$ trim. 2011 & 10 & 0 & 0 & 0 & 0 & 0 & 0 & 10 & $6^{\circ}$ \\
\hline $3^{\circ}$ trim. 2011 & 8 & 0 & 1 & 0 & 0 & 0 & 1 & 9 & \\
\hline
\end{tabular}

${ }^{500} \mathrm{O}$ Estudo sobre Fusões e Aquisições é realizado trimestralmente pela KPMG Corporate Finance, com diversas informações como ranking setorial de transações, distribuição geográfica das transações, participação dos países no número de transações do tipo cross border, evolução dos números em anos anteriores e outros comparativos. Em função do aumento considerável de fusões e aquisições de instituições educacionais, a partir de 2008 foi determinada uma categoria para o setor "Educação", até então classificado em "Outros". (Informações disponíveis em http://www.kpmg.com.br/publicacoes fas.asp?ft=5\&fx=16)

${ }^{501}$ No $2^{\circ}$ semestre de 2010, com uma só aquisição, o setor educacional foi incluído na categoria "outros" e, assim, não foi considerado para o ranking setorial de transações. 


\begin{tabular}{|c|c|c|c|c|c|c|c|c|c|}
\hline $4^{\circ}$ trim. 2011 & 3 & 0 & 0 & 0 & 0 & 0 & 0 & 3 & $19^{\circ}$ \\
\hline $1^{\circ}$ trim. 2012 & 2 & 2 & 0 & 0 & 0 & 0 & 2 & 4 & $17^{\circ}$ \\
\hline $2^{\circ}$ trim. 2012 & 3 & 1 & 0 & 0 & 0 & 0 & 1 & 4 & $11^{\circ}$ \\
\hline $3^{\circ}$ trim. 2012 & 3 & 4 & 0 & 0 & 0 & 0 & 4 & 7 & $8^{\circ}$ \\
\hline $4^{\circ}$ trim. 2012 & 3 & 1 & 0 & 0 & 0 & 0 & 1 & 4 & $11^{\circ}$ \\
\hline $1^{\circ}$ trim. 2013 & 3 & 3 & 0 & 1 & 0 & 0 & 4 & 7 & $7^{\circ}$ \\
\hline $2^{\circ}$ trim. 2013 & 3 & 0 & 0 & 0 & 2 & 0 & 2 & 5 & $10^{\circ}$ \\
\hline $3^{\circ}$ trim. 2013 & 7 & 2 & 0 & 1 & 0 & 0 & 3 & 10 & $6^{\circ}$ \\
\hline $4^{\circ}$ trim. 2013 & 2 & 0 & 0 & 0 & 0 & 0 & 0 & 2 & $22^{\circ}$ \\
\hline Total $^{\mathbf{5 0 2}}$ & $\mathbf{1 2 6}$ & $\mathbf{2 2}$ & $\mathbf{2}$ & $\mathbf{3}$ & $\mathbf{2}$ & $\mathbf{0}$ & $\mathbf{2 9}$ & $\mathbf{1 5 5}$ & $\mathbf{2 0}^{\circ}$ \\
\hline
\end{tabular}

$\mathrm{d}=$ domestic

$\mathrm{cb}=$ cross border

$\mathrm{cb} 1=$ cross border 1 (empresa de capital majoritário estrangeiro adquirindo, de brasileiros, capital de empresa estabelecida no Brasil) $\mathrm{cb} 2=$ cross border 2 (empresa de capital majoritário brasileiro adquirindo, de estrangeiros, capital de empresa estabelecida no exterior)

cb3 = cross border 3 (empresa de capital majoritário brasileiro adquirindo, de estrangeiros, capital de empresa estabelecida no Brasil)

cb4 $=$ cross border 4 (empresa de capital majoritário estrangeiro adquirindo, de estrangeiros, capital de empresa estabelecida no Brasil)

cb5 $=$ cross border 5 (empresa de capital majoritário estrangeiro adquirindo, de brasileiros, capital de empresa estabelecida no exterior)

${ }_{502}$ O ranking na última linha corresponde ao total acumulado de transações por setor, desde o início do "Plano Real", considerando que o setor educacional só aparece como um setor específico a partir de 2008. Mesmo sem ter suas transações entre os anos de 1994 e 2007 inclú́das no ranking setorial o setor educacional é o $20^{\circ}$ setor com maior número de fusões e aquisições. 